
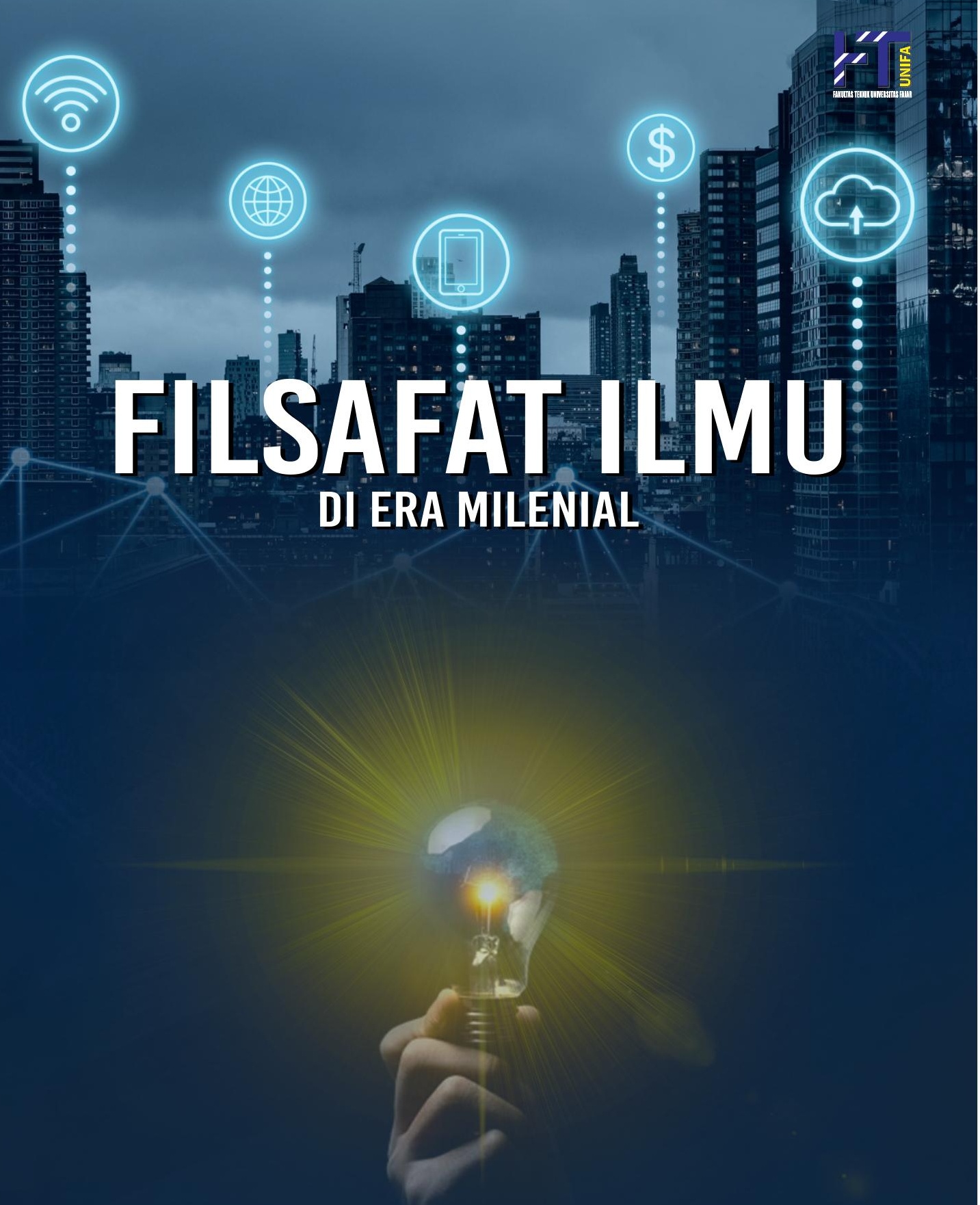

\# Ismail Marzuki \# Johra \# Arwansyah

\# Asrudin \# Zaenal \# Muhammad Riadi Harimuswarah

\# Muhammad Syahrir \# Muhammad Ramli \# Akbar Hadi 


\section{Filsafat Ilmu di Era Milenial}

\section{By}

\# Ismail Marzuki \# Johra \# Arwansyah \# \# Asrudin \# Zaenal \# Muhammad Riadi Harimuswarah \# \# Muhammad Syahrir \# Muhammad Ramli \# Akbar Hadi \# 



\section{Filsafat Ilmu di Era Milenial}

Penulis Dr. Ismail Marzuki, M.Si,

Johra, S.Pd,

Arwansyah, ST.,

Asrudin, ST,

Ir.Zaenal, ST

Muhammad Riadi Harimuswarah, ST.

Muhammad Syahrir, S.S.,

Muhammad Ramli,

Akbar Hadi, ST,

Editor Dr. Muhammad Asdar, S. Ksi., M.Si

Dr. Sry Gusti. ST., MT

Dr. Sri Adrianti Muin, SE., M.Si

Desain Grafis Alif Syabana Bahar

Layout ZulFahmi Noor

Diterbitkan oleh Fakultas Teknik Universitas Fajar

Jl. Prof. Abdurrahman Basalamah No. 101

Makassar 90231

Tlp. 082194130545

Fax. (0411) 441119

e-mail: ft@unifa.ac.id

Hak cipta dilindungi undang-undang pada penulis

ISBN 978-623-97118-0-1

Dicetak oleh team penerbit Fakultas Teknik Universitas Fajar 


\section{Kata Pengantar}

Ucapan rasa syukur dari hati yang paling dalam tercurahkan atas kehadirat Allah SWT yang telah memberi kesehatan, kekuatan, kesempatan dan kemampuan untuk dapat menyelesaikan naskah penulisan buku berjudul: Filsafat Ilmu di Era Milenial. Buku ini adalah karya bersama mahasiswa program Pascasarjana Magister Rekayasa Infrastruktur dan Lingkungan Universitas Fajar dalam bimbingan dan arahan dosen pengampuh matakuliah filsafat.

Buku ini diterbitkan didasarkan pada pemikiran matematis dan renungan serta evaluasi penugasan-penugasan yang diberikan mahasiswa dalam 3 tahun terakhir dalam matakuliah filsafat tersebut yang seolah bahwa tugas-tugas mahasiswa tidak begitu memberi arti dalam aspek pengembangan ilmu dan peningkatan wawasan berkehidupan dan dinamika sebagai makhluk sosial yang ada di belahan bumi ini. Penyelesaian tugas hanya dipandang sebagai bentuk menggugurkan kewajiban karena keinginan untuk lulus dalam matakuliah tersebut. Wawasan keilmuan jangka panjang dan review kebelakang atas dinamika perkembangan pengetahuan manusia, maka dilakukan inovasi dan kreativitas, yakni bersepakat dalam komunitas kecil matakuliah filsafat untuk menghasilkan setitik torehan pemikiran dalam goresan tinta hitam sebagai hasil pembelajaran dalam bentuk buku. Setetes harapan atas penerbitan buku ini agar dapat menjadi bahan bacaan generasi milenial yang notabene oleh banyak kalangan menjuluki komunitas mereka sebagai generasi Y atau generasi Echo Boomer yang lahir sebagai turunan dari Gen-X dan mengalami booming di awal abad ke 20. 
Buku ini disusun, tentu masih sangat sederhana dan bukan tidak mungkin merupakan buku dengan kualitas rendah dalam hal narasi-narasi yang tersampaikan termasuk dalam hal pengutipan, namun satu keyakinan kami bahwa dalam buku ini tetap memberi pencerahan walau hanya secerca manfaat, khususnya bagi mahasiswa kami untuk menanamkan kepada mereka agar terbiasa dengan narasi dan logika berpikir sistematis sekaligus titik awal untuk dapat berlayar dalam suatu penulisan karya-karya ilmiah.

Gempita literasi untuk kita semua, semoga dengan kreativitas dan inovasi serta semangat dalam menulis dapat dapat menginspirasi dan menumbuhkan semangat dalam berkarya. Kepada teman-teman dosen tidak terkecuali diri Saya, bahwa yang kami lakukan semata untuk menumbuhkan semangat yang bukan tidak mungkin juga dapat diikuti oleh dosen-dosen yang lainnya. Sehingga tugas-tugas mahasiswa dapat di runut kebelakang dalam bentuk buku, harapan dari kreativitas ini adalah tugas-tugas mahasiswa tidak hanya sekedar memenuhi kewajiban matakuliah, tetapi dapat menjadi karya yang terdokumentasi dan dapat dikenang sepanjang waktu.

Terima kasih untuk semua, para mahasiswaku atas segala usaha dan kerja kerasnya sehingga karya-karya kalian dapat terdokumentasi dalam buku ini, semoga kalian tetap dapat membaca kembali dan mereviewnya, sehingga Anda dapat menemukan titik dan sisi lemah dari karya-karya Anda ini, Aamiin...... Aamiin...... Aamiin.

Tim Penulis, 


\section{Daftar Isi}

Halaman Sampul_i

Kata Pengantar_iii

Daftar Isi_iv

Bab I Filsafat dalam Ontologi, Epistemologi dan Aksiologi _1

1.1 Filsafat dan Antropologi Manusia _1

1.2 Rekonstruksi Historis Ilmu Pengetahuan _ 2

1.3 Psikologi, Antropologi, Etnologi dan Sosiologi_5

1.4 Konsep Rasionalisme _11

1.5 Antropologi Metafisika_12

Bab II Filsafat Konvensional dan Filsafat Modern di Abad Kemajuan IPTek_15

2.1 Makna Filsafat terhadap Ilmu Pengetahuan Konvensional _15

2.2 Makna Filsafat terhadap Ilmu Pengetahuan Modern_18

2.3 IPTek AbaD 13 dan Abad ke 10_22

2.4 Implikasi Filsafat Terhadap Ilmu Pengetahuan_26

2.5 Relevansi Filsafat terhadap IPTek_29

Bab III Filsafat Zaman Yunani_33

3.1 Filsafat Orang Yunani_33

3.2 Filsafat Zaman Yunani_37

3.3 Neo Fytagoras, Neo Plato dan Neo Aristoteles _57

3.4 Filsafat Zaman Mesopotamia _64

3.5 Filsafat dan Teori Eksoterik dan Esoterik _77

3.6 Metode Induktif dan Deduktif_80 
Bab IV Konsep Filsafat Pendidikan Kebangsaan Cokroaminoto_83

4.1 Pendidikan Kebangsaan Tinjauan Sosial Cokroaminoto_83

4.2 Keluarga Sebagai Pondasi Pendidikan Kebangsaan Berbasis Tauhid_88

4.3 Pendidikan Agama dalam Pembentukan Nilai Kebangsaan_91

4.4 Pendidikan Intelektual dalam Bingkai Ilmu Sebagai Pembentukan Nilai-Nilai Kebangsaan_95

4.5 Pendidikan Kebangsaan dalam Memperkuat Jejaring Sosial_99

Bab V Manusia dan Perkembangan Ilmu Pengetahuan_105

5.1 Hakikat Ilmu Pengetahuan_105

5.2 Pengelompokan Pengetahuan_107

5.3 Pengetahuan Ilmiah_110

5.4 Sumber Pengetahuan Manusia _111

5.5 Objek dan Materi Pengetahuan Ilmiah_114

Bab VI Filsafat dan Holisme _117

6.1 Teori Berpikir Holistik_117

6.2 Paradigma Holistik_119

6.3 Relevansi Pendidikan Holistik_122

6.4 Konsep dan Teori Lahirnya Filsafat_123

6.5 Filsafat Holisme dan Ekologis _129

6.6 Contoh Berpikir Holistik_138

Bab VII Idealisme Filsafat terhadap Metode Kualitatif dan Kuantitatif_145

7.1 Pendahuluan_145

7.2 Filsafat Kausalitas dan Metode Ilmiah_152

7.3 Pandangan Filsafat terhadap Metode Kualitatif_155

7.4 Pandangan Filsafat terhadap Metode Kuanlitatif_156

7.5 Aspek Idealisme, Realisme dan Holisme Pendidikan Filsafat -162

Bab VIII Irisan Filsafat terhadap Logika dan Silogisme _165

8.1 Filsafat dan Logika_165

8.2 Silogisme dan Fissafat_172

8.3 Konsep Silogisme_175 


\section{Bab IX Filsafat di Era Generasi Milenial_181}

9.1 Pentingkah Filsafat di Era Milenial_181

9.2 Relevansi Filsafat di Era Milenial_182

9.3 Filsafat Umum dalam Pemikiran Milenial_186

9.4 Urgensi Filsafat dalam Era Globalisasi_188

9.5 Bagaimana Masa Depan Filsafat terhadap Generasi Milenial _189

Daftar Pustaka -193

Biodata Penulis _211

Sinopsis 


\section{Bab I \\ Filsafat dalam Ontologi, Epistemologi dan Aksiologi}

\subsection{Filsafat dan Antropologi Manusia}

Pada abad sebelumnya hingga kini abad ke-11 era milenial dan ribuan tahun akan datang, kajian tentang filsafat mendapat perhatian sangat besar dari para ilmuwan. Kata filsafat bersumber dari bahasa Yunani, bila diartikan dalam bahasa Arab dikenal dengan istilah falsafah dan bahasa Inggris philosophia terdiri atas kata philein yang berarti cinta dan kata Sophia yang artinya kebijaksanaan. Filsafat menggunakan metode dalam mengkaji seluruh fenomena kehidupan manusia dan alam semesta secara rasional dan mendalam sampai ke akarnya tentang persoalan pengetahuan, akal dan pikiran serta bahasa sehingga diperoleh kebenaran dari sesuatu yang dipelajari. Manusia merupakan sumber filsafat (Satria, 2020).

Manusia pada waktu terlahir ke bumi tidak tahu dan tidak mengenal yang ada disekitarnya, bahkan dengan dirinya sendiri dan akhirnya manusia mengenal alam sekitarnya, bagaimana sesuatu, untuk apa sesuatu dan apa manfaat sesuatu, karena selama hidupnya, sepanjang sejarah manusia selalu mencari kebenaran yang sesungguhnya. Filsafat menjadi segala ilmu dimana manusia mencari kebenaran dan akhirnya berkembang menjadi ilmu lain seperti antropologi manusia (Ja'far, 2018). Kata antropologi bersumber dari bahasa Yunani yaitu 
anthropos yang mempunyai arti manusia dan logos yang mempunyai arti ilmu. Antropologi merupakan studi yang mengkaji tentang manusia sebagai makhluk biologi dan sosial yang terdiri dari 1 cabang ilmu yaitu antropologi fisik (physical anthropology) dan antropologi budaya (cultural anthropology). Antropologi fisik mengkaji manusia secara organisme biologi dengan menekankan kajian pada evolusi manusia yaitu ditemukannya sisa - sisa makhluk hidup yang telah membatu dalam kurung jutaan tahun yang lalu dalam tanah (fosil) dan antropologi budaya mengkaji kebudayaan manusia yang beragam dari berbagai bangsa yang ada di dunia yaitu dengan berbudaya dan mengembangkan budaya dari waktu ke waktu. Beberapa perkembangan antropologi seperti antropologi ekologi, agama, perkotaan, ekonomi, psikologi, Kesehatan, politik, maritime, dan lain sebagainya (Thamrin et. all 2013).

\subsection{Rekonstruksi Historis Ilmu Pengetahuan}

Manusia adalah makhluk rasional sehingga mereka mampu merumuskan makna-makna yang melibatkan penilaian, pembedaan dan penjelasan yang tentunya dengan pengetahuan dan akal yang mereka fungsikan. Pengetahuan merupakan sumber realitas atas asumsi dasar manusia. Tanpa pengetahuan manusia tidak dapat membedakan hal-hal yang bisa ditangkap dengan panca indera, maka istilah "pengetahuan" itu cukup luas artinya, Istilah ini menunjukan bahwa manusia sadar akan barang-barang di sekitarnya; adanya manusia di dunia ini lain daripada adanya sebuah barang mati. Kata "pengetahuan" tidak hanya meliputi pengetahuan ilmiah, melainkan pula pengalaman pribadi, melihat dan mendengar, perasaan dan intuisi, dugaan dan suasana jiwa. Pengetahuan merupakan pokok kajian dalam ilmu filsafat. Dalam filsafat pengetahuan termasuk dalam kajian "epistemologi" dengan kata lain episteme (pengetahuan) dan logos (kata/pembicaraan/ilmu) adalah cabang filsafat yang berkaitan dengan asal, sifat, karakter dan jenis pengetahuan. Topik ini termasuk salah satu yang paling sering diperdebatkan dan dibahas dalam bidang filsafat, misalnya tentang yang dimaksud pengetahuan, bagaimana unsur-unsurnya, asal-usulnya, serta jenis kebenaran suatu pengetahuan itu sendiri (Nugraha, 2012). Epistemologi atau Teori Pengetahuan yang berhubungan dengan hakikat dari ilmu pengetahuan, pengandaian-pengandaian, dasar-dasarnya serta pertanggung jawaban atas pernyataan mengenai pengetahuan yang dimiliki oleh 
setiap manusia merupakan kajian yang sangat mendalam dan menarik untuk diperbincangkan di kalangan akademisi (Hifni, 2018).

Banyak orang mengartikan pengetahuan dan ilmu pengetahuan itu sama, hal tersebut memang tidak salah seluruhnya namun perlu ditinjau berdasarkan kaidah keilmuan agar dapat memahami sesungguhnya. Sebagaimana analogi yang telah dipaparkan, bahwa ilmu pengetahuan adalah tahapan atau bagian dari pengetahuan. Sehingga dapat dipahami bahwa pengetahuan berbeda dengan ilmu. Lebih tepatnya ilmu adalah bagian dari pengetahuan. Kata ilmu merupakan terjemahan dari kata "science", yang secara etimologis berasal dari kata latin "scientia", artinya "to know". Namun, pengertian science ini sering salah diartikan, dan reduksi berkaitan dengan ilmu alam semata padahal tidak demikian. Dalam Kamus Besar Bahasa Indonesia, ilmu merupakan pengetahuan tentang suatu bidang yang disusun secara bersistem menurut metode tertentu, yang dapat digunakan untuk menerangkan gejala tertentu di bidang (pengetahuan) itu(Daud, 2016).

Pendapat lain menerangkan bahwa ilmu merupakan pengetahuan yang mengembangkan dan melaksanakan aturan-aturan mainnya dengan penuh tanggung jawab dan kesungguhannya. Melalui pendapat tersebut dipahami bahwa ilmu merupakan pengembangan dari pengetahuan yang memiliki aturan tertentu dan dapat diuji kebenarannya karena berkaitan dengan penafsiran suatu hal yang pada umumnya berlaku secara umum. Fisik yang terdiri atas bagianbagian dalam keadaan saling terkait satu dengan yang lainnya. Metode Empiris dan penelitian empiris, konsep sentral dalam ilmu pengetahuan dan metode ilmiah adalah bahwa semua bukti harus empiris, atau berbasis empiris, yaitu, bergantung pada bukti-bukti yang diamati oleh indera. Hal ini dibedakan dari penggunaan filosofis empirisme oleh penggunaan kata sifat "empiris" atau adverbia yang "empiris". Empiris yang digunakan bersama dengan baik alam dan ilmu-ilmu sosia, dan mengacu pada penggunaan kerja hipotesis yang dapat diuji menggunakan pengamatan atau percobaan. Dalam arti kata, laporan ilmiah untuk tunduk dan berasal dari pengalaman kami atau observasi. Dalam arti kedua "empiris" dalam ilmu dan statistik mungkin identik dengan "eksperimental". Dalam hal ini, hasil pengamatan empiris adalah eksperimental. Istilah semi-empiris yang kadang-kadang digunakan untuk menggambarkan metode teoritis yang menggunakan dasar aksioma, hukum ilmiah didirikan, dan hasil eksperimen sebelumnya dalam rangka untuk terlibat dalam pembentukan model beralasan dan penyelidikan teoritis (Murdiyanto, (2017). 
Tokoh-Tokoh Empirisme yaitu Francis Bacon, Thomas Hobbes, John Locke, David Hume dan Rasionalisme. Rasionalisme adalah paham yang mengajarkan bahwa sumber pengetahuan satu-satunya yang benar adalah rasio (akal budi), Rasionalisme adalah paham filsafat yang mengatakan bahwa akal (resen) adalah alat terpenting dalam memperoleh pengetahuan dan mengatur pengetahuan. Jika empirisme mengatakan bahwa pengetahuan diperoleh dengan alam mengalami objek empiris, maka rasionalisme mengajarkan bahwa pengetahuan diperoleh dengan berpikir alat dalam berfikir itu adalah kaidah-kaidah logis atau kaidahkaidah logika. Pengetahuan rasional atau pengetahuan yang bersumber dari akal (rasio) adalah suatu pengetahuan yang dihasilkan dari proses belajar dan mengajar, diskusi ilmiah, pengkajian buku, pengajaran seorang guru, dan sekolah (Laksana, dkk, 2.

Intuisi merupakan suatu sarana untuk mengetahui secara langsung dan seketika. Unsur utama bagi pengetahuan adalah kemungkinan adanya suatu bentuk penghayatan langsung (intuitif), di samping pengalaman oleh indera. Secara epistemologis, pengetahuan intuitif berasal dari intuisi yang diperoleh melalui pengamatan langsung, tidak mengenai objek lahir melainkan mengenai kebenaran dan hakikat sesuatu objek. Metode intuisi sebenarnya tidak bisa dibuktikan secara rasional maupun empiris. Akan tetapi, hasil dari kebenaran intuisi tersebut dapat dibuktikan secara rasional sekaligus empiris. Artinya, banyak orang yang memperoleh pengetahuan yang mendalam secara intuitif yang kemudian terbukti benar. Oleh karena itu, Bergson mengatakan bahwa intuisi sebenarnya bersifat intelektual dan sekaligus supra-intelektual, dimana pengetahuan supra-intelektual tersebut dapat mencapai pengetahuan dan kesadaran diri pada hal-hal yang paling vital, elan vital. Sementara bagi Nietzsche intuisi merupakan inteligensi yang paling tinggi, dan bagi Maslow intuisi merupakan pengalaman puncak (peak experience). Tokoh-Tokoh Intuïtionisme yaitu Immanuel Kant, Luitzen Egbertus Jan Brouwer, Arend Heyting, Sir Michael Anthony Eardley Dummett dan Kritisisme. Kant membedakan pengetahuan ke dalam empat bagian, yaitu Yang analitis apriori, sintesis apriori, analitis aposteriori, dan sintesis a posteriori. Pengetahuan a priori adalah pengetahuan yang tidak tergantung pada adanya pengalaman atau, yang ada sebelum pengalaman. Sedangkan pengetahuan a posteriori terjadi sebagai akibat pengalaman (Jamaluddin, 2015).

Pengetahuan yang analitis merupakan hasil analisa dan pengetahuan sintetis merupakan hasil keadaan yang mempersatukan dua hal yang biasanya terpisah Pengetahuan yang analitis apriori adalah pengetahuan yang dihasilkan oleh analisis terhadap unsur-unsur yang a priori. Pengetahuan sintesis apriori 
dihasilkan oleh penyelidikan akal terhadap bentuk-bentuk pengalamannya sendiri dan penggabungan unsur-unsur yang tidak saling bertumpu. Misal, $7-1$ = 5 merupakan contoh pengetahuan semacam itu. Pengetahuan sintesis a posteriori diperoleh setelah adanya pengalaman. Dengan filsafatnya bermaksud memugar sifat obyektivitas dunia dan ilmu pengetahuan. Agar maksud tersebut terlaksana orang harus menghindarkan diri dari sifat sepihak. Menurut Kant ilmu pengetahuan adalah bersyarat pada: a) bersifat umum dan bersifat perlu mutlak dan b) memberi pengetahuan yang baru. Kant bermaksud mengadakan penelitian yang kritis terhadap rasio murni dan realita. Kant yang mengajarkan tentang daya pengenalan mengemukakan bahwa daya pengenalan roh adalah bertingkat, dari tingkatan terendah pengamatan inderawi, menuju ke tingkat menengah akal (Verstand) dan yang tertinggi rasio atau buddhi (Vernunft) (Haryono, 2015).

Immanuel Kant menganggap Empirisme (pengalaman) itu bersifat relatif bila tanpa ada landasan teorinya. contohnya adalah kamu selama ini tahu air yang dimasak sampai mendidih pasti akan panas, itu kita dapat dari pengalaman kita di rumah kita di Indonesia ini, namun lain cerita bila kita memasak air sampai mendidih di daerah kutub yang suhunya di bawah $0^{\circ} \mathrm{C}$, maka air itu tidak akan panas karena terkena suhu dingin daerah kutub, karena pada teorinya suhu air malah akan menjadi dingin.dan contoh lainnya adalah pada gravitasi, gravitasi hanya dapat dibuktikan di bumi saja, tetapi tidak dapat diterapkan di bulan. Jadi sudah terbukti bahwa pengalaman itu bersifat relatif, tidak bisa kita simpulkan atau kita iyakan begitu saja tanpa dibuktikan dengan sebuah akal dan teori. Dan oleh karena itu Ilmu pengetahuan atau Science haruslah bersifat berkembang, tidak absolute atau mutlak dan tidak bertahan lama karena melalui perubahan yang mengikuti perkembangan zaman yang terus maju. Ada kemungkinan, Sir Isaac Newton bila hidup kembali bakal merevisi teori Gravitasinya kembali) Pengalaman juga bersifat data-data Inderawi (Elisanti, 2009).

\subsection{Psikologi, Antropologi, Etnologi dan Sosiologi}

Kata psikologi berasal bahasa Yunani Kuno yaitu psyche yang berarti jiwa dan logos yang berarti kata, sehingga secara harfiah diartikan sebagai ilmu jiwa. Dalam arti bebas, psikologi adalah ilmu yang mempelajari tentang kegiatan 
tingkah laku dan proses mental. Jiwa tidak tampak atau bersifat abstrak, maka dapat dilihat atau diobservasi melalui perilaku atau aktivitas-aktivitas, sehingga psikologi merupakan ilmu yang meneliti dan mempelajari tentang perilaku atau aktivitas-aktivitas sebagai manifestasi hidup kejiwaan atau penjelmaan dari kehidupan jiwa itu sendiri. Psikologi pertama kali dikembangkan di Leipzig dengan mendirikan laboratorium psikologi oleh Wilhelm Wundt pada tahun 1879 sebagai bapak pendiri dengan tujuan untuk memajukan ilmu pengetahuan, kemudian dipelopori oleh William James karena menurutnya pendapat Wilhelm Wundt keliru apabila percobaannya lebih berpusat pada penemuan struktur dan bukan kesadaran atau respons manusianya. Di Indonesia psikologi berkembang pada tahun 1953 yang dipelopori oleh Slamet Iman Santoso dengan mendirikan secara mandiri lembaga psikologi dan tahun 1960 dikembangkan oleh UGM dan UNPAD (Hedi Sasrawan). Sejarah psikologi dapat dibagi menjadi beberapa periode, yaitu: (1) Periode Pra berdirinya Psikologi, (1) Psikologi Sebagai Ilmu yang Otonom, (3) Perkembangan Psikologi Modern. Sedangkan aliran-aliran psikologi terdiri dari Strukturalisme, Fungsionalisme, Behaviorisme, Gestalt Psychology, Psikoanalisis dan Humanistic Psychology. Aliran konsep keilmuan psikologi menunjukkan perkembangan dalam mempelajari kejiwaan manusia dan para psikolog yang tidak menganut aliran ini akan mengembangkan atau menggunakan teori psikologi lainnya (Budiati, 2009).

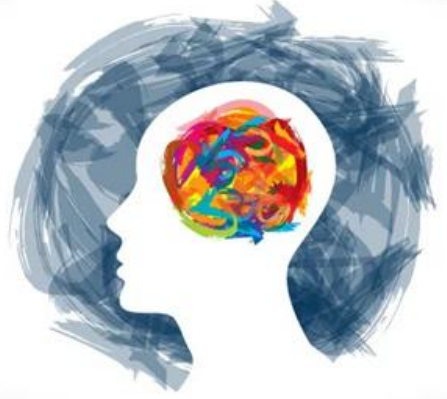

Gambar 1.3.1 Ruang lingkup psikologi

Ruang lingkup psikologi terdiri dari: Psikologi Sosial (Social Psychology), Psikologi Kesehatan, Psikologi Klinis dan Penyuluhan atau Konseling (Clinical Psychology and Counseling), Psikologi Konstitusional, Psikofarmakologi, Psikologi Okupasional (Occupational Psychology), psikologi Politik, Psikologi Sekolah dan Pendidikan (Psychology for the Classroom and Educational 
Psychology), Psikologi Perkembangan, Psikologi Kepribadian, Psikologi Lintas Budaya (Cross-Cultural Psychology), Psikologi Rekayasa (Engineering Psychology), Psikologi Lingkungan, Psikologi Konsumen (Consumer Psychology) dan Psikologi Industri dan Organisasi (Industrial and Organizational Psychology). Memasuki abad ke-18 filsafat antropologi berkembang dari filsafat psikologi rasional yang dipelopori oleh Christian von Wolff yaitu ilmu filsafat dengan tujuan untuk membuktikan validitas dari gagasan tentang kapasitas konseptual pikiran, kehendak bebas, dan jiwa spiritual (Damsar, 2015).

Antropologi adalah ilmu tentang manusia. Antropologi berasal dari kata Yunani

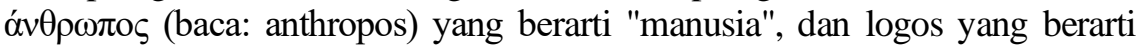
"wacana" (dalam pengertian "bernalar", "berakal") atau secara etimologis antropologi berarti ilmu yang mempelajari manusia. Kajian terhadap manusia, antropologi mengedepankan dua konsep penting yaitu: Holistik dan Komparatif. Karena itu kajian antropologi sangat memperhatikan aspek sejarah dan penjelasan menyeluruh untuk menggambarkan manusia melalui pengetahuan ilmu sosial ilmu hayati (alam), dan juga humaniora (Murdiyanto, 2008).

Antropologi bertujuan untuk lebih memahami dan mengapresiasi manusia sebagai entitas biologis homo sapiens dan makhluk sosial dalam kerangka kerja yang interdisipliner dan komprehensif. Antropologi menggunakan teori evolusi biologi dalam memberikan arti dan fakta sejarah dalam menjelaskan perjalanan umat manusia di bumi sejak awal kemunculannya. Antropologi juga menggunakan kajian lintas-budaya (Inggris cross-cultural) dalam menekankan dan menjelaskan perbedaan antara kelompok-kelompok manusia dalam perspektif material budaya, perilaku sosial, bahasa, dan pandangan hidup.

Orientasi antropologi yang holistik, antropologi dibagi menjadi empat cabang ilmu yang saling berkaitan, yaitu: Antropologi Biologi, Antropologi Sosial Budaya, Arkeologi, dan Linguistik. Keempat cabang tersebut memiliki kajiankajian konsentrasi tersendiri dalam kekhususan akademik dan penelitian ilmiah, dengan topik yang unik dan metode penelitian yang berbeda-beda (Satria et al, 2020).

Antropologi lahir atau berawal dari ketertarikan orang-orang Eropa pada ciriciri fisik, adat istiadat, dan budaya etnis-etnis lain yang berbeda dari masyarakat yang dikenal di Eropa. Pada saat itu kajian antropologi lebih memusatkan pada penduduk yang merupakan masyarakat tunggal, tunggal dalam arti kesatuan masyarakat yang tinggal di suatu kawasan geografis yang sama, memiliki ciri 
fisik dan bahasa yang digunakan serupa, serta cara hidup yang sama (Budiati, 2009).

Antropologi dibagi menjadi empat cabang ilmu yaitu antropologi budaya yang terdiri dari tiga bagian ilmu yaitu Etnologi, Arkeologi, Linguistik dan antropologi Fisik (Winny, et. al 2013) . Cabang - cabang ilmu antropologi dapat dilihat pada Gambar 1.3.2 di bawah ini

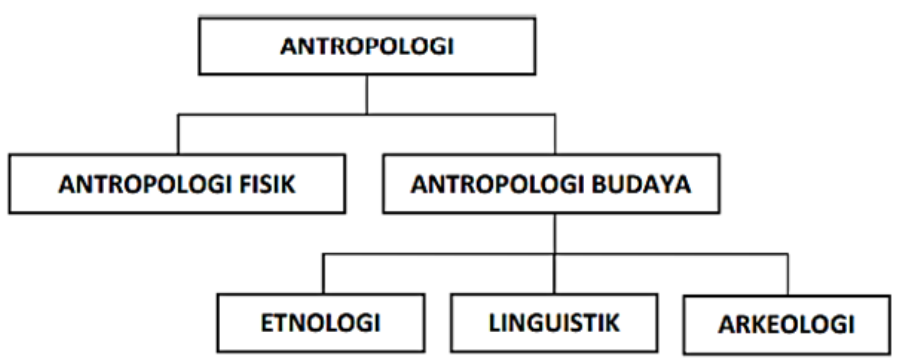

Gambar 1.3.2 Cabang-cabang ilmu antropologi

Pertengahan abad ke-19 berkembang salah satu ilmu antropologi yang berusaha mengumpulkan, menyusun, dan menganalisis bahan keterangan tentang kebudayaan berbagai suku bangsa di dunia, yang bersumber pada kisah-kisah perjalanan, laporan dan karangan etnografi berdasarkan pandangan dan teoriteori yang berkembang pada masa itu yang menghasilkan antropologi budaya yang disebut dengan etnologi. Ilmu ini mengkaji bagaimana manusia mampu berkebudayaan dan mengembangkan kebudayaannya dari masa ke masa. Fokus yang dipelajari oleh ilmu ini adalah model hidup manusia dalam memelihara dan mengubah lingkungannya. Cara hidup ini diperoleh manusia melalui proses belajar (sosialisasi) dan pengalaman hidup. Sosiologi berasal dari bahasa Latin yaitu socius yang berarti teman atau kawan, dan berasal dari bahasa Yunani yaitu logos yang berarti pengetahuan. Pada tahun 1011 sosiologi mempelajari masyarakat, perilaku masyarakat dan sosial manusia dengan mengamati perilaku kelompok yang dibangunnya yang merupakan pengetahuan kemasyarakatan yang tersusun dari hasil-hasil pemikiran ilmiah dan dapat dikontrol secara kritis oleh orang lain. Dengan pengertian tersebut, hubungan antara antropologi dengan sosiologi sangat erat. Apabila kajian antropologi 
adalah manusia, fisik, dan kebudayaannya, kajian sosiologi adalah hubungan antara struktur sosial dengan kebudayaan masyarakat (Thamrin et. al., 2013).

Etnologi adalah salah satu cabang ilmu antropologi budaya. Bahasan utamanya mengenai asas kemanusiaan dalam kebudayaan berbagai suku bangsa. Informasi diperoleh melalui pencatatan secara rinci terhadap suatu kebudayaan di masa lalu dan masa kini. Lingkup utamanya adalah penyebab perbedaan pola pikir dan pola perilaku individu dalam suatu kebudayaan. Etnologi telah digunakan dalam pengembangan teori-teori komunikasi. Selain itu, etnologi juga digunakan dalam ilmu antropologi sosial budaya (Nurmansyah et al., 2019).

Etnologi menggunakan asas kemanusiaan sebagai pembentuk keilmuannya. Asas ini utamanya berkaitan dengan kajian budaya dari berbagai suku bangsa. Pengetahuan mengenai kebudayaan dibentuk melalui pengamatan berulang kali terhadap penyebaran beragam suku bangsa pada masa tertentu. Data yang dikumpulkan berupa informasi mengenai sejarah perkembangan identitas dari suku-suku yang berpindah-pindah tempat. Etnologi lebih mengutamakan pencarian informasi tentang nilai budaya dan karakter manusia dari suku-suku yang telah ada di masa kini dibandingkan dengan yang ada di masa lampau. Informasi diperoleh secara rinci melalui catatan-catatan yang ada. Catatan ini berasal dari informasi awal dari kebudayaan suku bangsa yang akan diteliti. Dalam pelaksanaannya diterapkan ilmu etnografi (Rejeki, 2010).

Ruang lingkup etnologi adalah tentang hal-hal yang menciptakan perbedaan pola pikir dan perilaku individu pada masa lalu dan masa kini serta penyebabnya. Pola pikir dan pola perilaku ini meliputi ritual pernikahan, ekonomi, politik dan agama. Selain itu, etnologi juga membahas tentang perbedaan pola perilaku dalam tradisi lisan, kesenian pada masa lalu dan masa kini. Etnologi juga mengkaji tentang perubahan kebudayaan akibat perkembangan kebudayaan itu sendiri atau pengaruh dari kebudayaan lain. Etnologi telah digunakan dalam mengembangkan teori-teori komunikasi (Satria et al., 2020) Penggunaannya terutama dalam bidang komunikasi lintas budaya dan komunikasi antarbudaya. Selain itu, etnologi juga melandasi penemuan teori-teori tentang pengalaman dan interpretasi dalam bidang etnografi. Hal ini kemudian digunakan dalam memahami tindakan suatu kelompok masyarakat atau kebudayaan (Rejeki, 2010)

Etnologi juga digunakan dalam ilmu antropologi sosial dan antropologi budaya. Penggunaan etnologi membuat para peneliti tidak perlu secara langsung berada di lokasi penelitian. Mereka hanya perlu melakukan studi perbandingan 
terhadap berbagai tradisi dan kebudayaan dengan memanfaatkan literatur keilmuan (Nurmansyah et al., 2019).

Sosiologi adalah ilmu yang membahas tentang berbagai aspek dalam masyarakat serta pengaruhnya bagi kehidupan manusia. Istilah sosiologi pertama kali digunakan oleh Auguste Comte dan kemudian diperluas menjadi suatu disiplin ilmiah oleh Émile Durkheim. Perkembangan sosiologi sebagai ilmu dibagi menjadi empat tahap, yaitu masa abad pertengahan, masa abad renaisans, masa sosiologi sebagai ilmu tentang masyarakat dengan menggunakan metode ilmiah dari keilmuan lain (abad ke-18 M), dan masa sosiologi sebagai ilmu dengan metode ilmiah yang mandiri (abad ke-19 M) (Budiati, 2009). Sosiologi memiliki objek kajian yang jelas dan dapat diselidiki melalui metode-metode ilmiah serta dapat disusun menjadi suatu sistem yang masuk akal dan saling berhubungan. Objek kajian utama dalam sosiologi adalah struktur masyarakat, unsur sosial, sosialisasi dan perubahan sosial. Cabangcabang ilmu sosiologi bersifat gabungan antara ilmu tentang gejala sosial yang terjadi dalam masyarakat dengan ilmu-ilmu lainnya (Damsar, 2015)

Pada awalnya, manusia menyatukan segala bidang pengetahuan sebagai bagian dari filsafat alam. Kemudian filsafat alam berkembang menjadi berbagai cabang ilmu, salah satunya ialah filsafat sosial. Filsafat sosial membahas tentang etika yang perlu ada dan diterapkan di dalam masyarakat. Tokoh-tokohnya yaitu Plato (429-347 SM) dan Aristoteles (384-322 SM). Plato membahas tentang unsur sosiologi dalam bernegara, sedangkan Aristoteles membahas tentang etika sosial. Dalam perkembangannya, sosiologi menjadi pengetahuan yang berbeda dengan filsafat sosial (Elisanti dan Rostini, 2009). Sosiologi lebih mengutamakan pengetahuan tentang realitas sosial di dalam masyarakat, dibandingkan dengan pengetahuan tentang cara masyarakat dalam menerapkan etika. Konsep sosiologi kemudian dikembangkan oleh Thomas Hobbes, John Locke, dan Jean Jacques Rousseau melalui pemikiran tentang kontak sosial. Konsep pemikiran sosiologi ini belum dianggap sebagai ilmu hingga awal tahun 1800-an (Haryanto, 2015).

Istilah sosiologi digunakan pertama kali oleh Auguste Comte dalam bukunya yang berjudul "Cours De Philosophie Positive" yang diterbitkan pada tahun $1838 \mathrm{M}$ dan kemudian dipopulerkan oleh Herbert Spencer pada tahun 1876 melalui penerbitan bukunya yang berjudul Principles of Sociology. Istilah sosiologi diperoleh dari dua kata dalam bahasa Latin yaitu Socius dan Logos. Kata Socius berarti kawan, sedangkan kata Logos berarti ilmu pengetahuan (Laksana et al., 2017). 


\subsection{Konsep Rasionalisme}

Antroposofi adalah sebuah istilah yang digunakan untuk menerangkan pengetahuan tentang manusia. Namun hal ini berkaitan dengan aspek pengetahuan yang ingin menjelaskan tentang Tuhan atau yang disebut teosofi. Istilah Antroposofi sendiri berasal dari bahasa Yunani, anthropos dan sophia, yaitu manusia dan pengetahuan. Sedangkan Antropologi adalah ilmu tentang manusia. Antropologi berasal dari kata Yunani (baca: anthropos) yang berarti "manusia" atau "orang", dan logos yang berarti "wacana" (dalam pengertian "bernalar", "berakal") atau secara etimologis antropologi berarti ilmu yang mempelajari manusia. Dalam melakukan kajian terhadap manusia, antropologi mengedepankan dua konsep penting yaitu: holistik dan komparatif. Karena itu kajian antropologi sangat memperhatikan aspek sejarah dan penjelasan menyeluruh untuk menggambarkan manusia melalui pengetahuan ilmu sosial ilmu hayati (alam), dan humaniora (Laksana, et al., 2017).

Antropologi bertujuan lebih memahami dan mengapresiasi manusia sebagai entitas biologis homo sapiens dan makhluk sosial dalam kerangka kerja yang interdisipliner dan komprehensif. Oleh karena itu, antropologi menggunakan teori evolusi biologi dalam memberikan arti dan fakta sejarah dalam menjelaskan perjalanan umat manusia di bumi sejak awal kemunculannya. Antropologi menggunakan kajian lintas-budaya (Inggris cross-cultural) dalam menekankan dan menjelaskan perbedaan antara kelompok-kelompok manusia dalam perspektif material budaya, perilaku sosial, bahasa, dan pandangan hidup (worldview). Max Dessoir pada buku "From the Beyond of the Soul" berisi bagian singkat di mana humaniora yang berorientasi pada antroposofi yang wakili harus diidentifikasi sebagai tidak dapat dibenarkan secara ilmiah. Sekarang, bagi sebagian orang tampaknya diskusi dengan tokoh-tokoh yang didasarkan pada sudut pandang ilmiah Dessoir harus steril dalam semua keadaan untuk perwakilan antroposofi humaniora. Karena yang terakhir harus menegaskan bidang pengalaman intelektual murni yang ditolak secara fundamental dan merujuk pada ranah imajiner. Karena itu orang hanya dapat berbicara tentang pengetahuan humaniora yang relevan kepada seseorang yang percaya sejak awal ada alasan untuk fakta bidang humaniora yang dimaksud adalah kenyataan. 
Pandangan ini akan benar jika perwakilan antroposofi menyajikan tidak lain dari pengalaman pribadinya, dan ini hanya berdiri di samping hasil sains berdasarkan pengamatan sensorik dan proses ilmiah pengamatan ini. Kemudian orang dapat mengatakan profesor sains yang ditandai dengan cara ini hanya menolak untuk menganggap pengalaman penjelajah alam spiritual sebagai kenyataan, dan ia hanya dapat membuat kesan dengan orang yang telah dikedepankannya pada kepribadian yang, sejak awal, menempatkan diri pada sudut pandangnya. Gagasan ini merupakan sistem filsafat-religius yang dikemukakan oleh Rudolf Steiner (1861/1915). Teori ini sangat dipengaruhi oleh teologi agama Hindu. Sekilas mengenai Steiner, adalah ahli dalam bidang spiritualitas, hidup di India untuk melakukan penelitiannya, dan selalu tertarik dengan hidup yang sarat misteri; ia mendalami yoga, karma, Buddhisme dan filsafat Timur di India. Waktu kemunculannya adalah menjelang Perang Dunia I, dan diperkirakan masih hidup di Republik Federal Jerman, Inggris dan Amerika Serikat. Pemikiran Anthroposophy disebut sebagai teori mistis, percampuran religius filosofis yang dipinjam dari pemikiran neoplatonisme dan Pythagorean, mistisisme, Kabala dan filsafat alam Jerman. Teorinya berciri pendewaan terhadap kodrat manusia yang memiliki karsa atau kehendak. Bagi teori ini, kodrat yang ada pada manusia hanya bisa disingkap oleh manusia yang memiliki karsa (Ja'far, 2018)

\subsection{Antropologi Metafisika}

Metafisika sering disebut ontologi yang secara histori bersumber dari filsafat. Kata metafisika berasal dari bahasa Yunani yaitu meta yang artinya setelah atau dari belakang dan fisika yang berarti sesuatu di alam nyata. Metafisika merupakan disiplin yang mengkaji tentang hal-hal secara fisik yang bersifat benda-benda yang ada (realitas) atau universal dia balik alam nyata (Krisna Sukma Yogiswari, at.all, 1018). Ahli metafisika juga berupaya memperjelas pemikiran-pemikiran manusia mengenai dunia, termasuk keberadaan, kebendaan, sifat, ruang, waktu, hubungan sebab akibat, dan kemungkinan yang pada awalnya diperkenalkan oleh Aristoteles yang pada akhirnya disebarluaskan oleh Andronikos dari Rodi pada abad I SM. Para pemikir metafisika seperti Plato dan Aristoteles memberikan asumsi dasar bahwa dunia atau realitas adalah yang dapat dipahami (intelligible) yang mana setiap aliran metafisika mengklaim bahwa akal budi memiliki kapasitas memadai untuk 
memahami dunia yang memiliki kualitas ampuh untuk menyimak semua realitas mendasar dari segala yang ada. Manusia memberikan pendapat mengenai tafsiran metafisika. Ilmu metafisika kemudian dianggap sebagai ilmu gaib. Tafsiran yang pertama yang dikemukakan oleh manusia terhadap alam ini adalah bahwa terdapat hal-hal gaib (supranatural) dan hal-hal tersebut bersifat lebih tinggi atau lebih kuasa dibandingkan dengan alam yang nyata. Pemikiran seperti ini disebut pemikiran supernaturalisme. Dari sini lahir tafsiran-tafsiran cabang misalnya animisme. Selain paham diatas, ada juga paham yang disebut paham naturalisme (Damsar, 2015).

Paham ini sangat bertentangan dengan paham supernaturalisme. Paham naturalisme menganggap bahwa gejala-gejala alam tidak disebabkan oleh halhal yang bersifat gaib, melainkan karena kekuatan yang terdapat dalam alam itu sendiri, yang dapat dipelajari dan diketahui.Penganut paham naturalisme percaya bahwa setiap gejala, gerak bisa dijelaskan menurut hukum kausalitas (hukum sebab-akibat) atau hukum stimulus-respon. Contoh: bola bilyard tidak akan bergerak kecuali karena ada bola yang menabraknya atau disodok oleh tongkat bilyard. Metafisika menuntut orisinalitas berpikir yang biasanya muncul melalui kontemplasi atau intuisi berupa kilatan-kilatan mendadak akan sesuatu, hingga menjadikan para metafisikus menyodorkan cara berpikir yang cenderung subjektif dan menciptakan terminology filsafat yang khas. Situasi semacam ini dinyatakan oleh Van Peursen sangat diperlukan untuk pengembangan ilmu dalam rangka menerapkan heuristika. Berkaitan dengan pembentukan minat intelektual, maka metafisika mengajarkan mengenai cara berpikir yang serius dan mendalam tentang hakikat-hakikat segala sesuatu yang bersifat enigmatik, hingga pada akhirnya melahirkan sikap ingin tahu yang tinggi sebagaimana mestinya dimiliki oleh para intelektual. Metafisika mengajarkan pada peminat filsafat untuk mencari prinsip pertama sebagai kebenaran yang paling akhir. Axiologi (teori tentang nilai) sebagai filsafat yang membahas apa kegunaan ilmu pengetahuan bagi manusia (Hifni, 2018).

Aksiologi menjawab, untuk apa pengetahuan yang berupa ilmu itu dipergunakan? Bagaimana kaitan antara cara penggunaan tersebut dengan kaidah-kaidah moral? Bagaimana penentuan objek yang ditelaah berdasarkan pilihan-pilihan moral? Bagaimana kaitan antara teknik prosedural yang merupakan operasionalisasi metode ilmiah dengan norma-norma moral? Dengan demikian Aksiologi adalah nilai-nilai (value) sebagai tolok ukur kebenaran (ilmiah), etik, dan moral sebagai dasar normatif dalam penelitian dan penggalian, serta penerapan ilmu. Pembahasan yang mendalam tentang keberadaan metafisika dalam ilmu pengetahuan memberikan banyak wawasan 
bagaimana metafisika merupakan hal substantif dalam menelaah lebih jauh konsep keilmuan dalam menunjang kejayaan manusia dalam berfikir dan menganalisis. Sehingga manfaat yang mutlak terhadap pengembangan ilmu dipaparkan Kuhn bahwa kontribusi metafisika terletak pada awal terbentuknya paradigma ilmiah, ketika kumpulan kepercayaan belum lengkap pengumpulan faktanya, maka ia harus dipasok dari luar, antara lain: metafisika, sains yang lain, kejadian personal dan historis serta metafisika mengajarkan sikap open-ended, sehingga hasil sebuah ilmu selalu terbuka untuk temuan dan kreativitas baru. Selanjutnya Kennick juga mengungkapkan bahwa metafisika mengajarkan cara berpikir yang serius, terutama dalam menjawab problem yang bersifat enigmatis (teka-teki), sehingga melahirkan sikap dan rasa ingin tahu yang mendalam.Perdebatan dalam metafisika melahirkan berbagai aliran, mainstream seperti : Monisme, Dualisme, Pluralisme, sehingga memicu proses ramifikasi, berupa lahirnya percabangan ilmu. Sementara Van Peursen mengatakan bahwa metafisika menuntut orisinalitas berpikir, karena setiap metafisikus menyodorkan cara berpikir yang cenderung subjektif dan menciptakan terminology filsafat yang khas. Situasi semacam ini diperlukan untuk pengembangan ilmu dalam rangka menerapkan heuristika (Nugraha, 2012).

Metafisika mengajarkan pada peminat filsafat untuk mencari prinsip pertama (First Principle) sebagai kebenaran yang paling akhir. Serta hal yang paling booming dalam dunia filsafat adalah bagaimana Descartes mengungkapkan bahwa Kepastian ilmiah dalam metode skepticnya hanya dapat diperoleh jika kita menggunakan metode deduksi yang bertitik tolak dari premis yang paling kuat (Cogito ergo sum) Skeptis-Metodis Rene Descartes. Disamping itu Bakker mengemukakan bahwasanya metafisika mengandung potensi untuk menjalin komunikasi antara pengada yang satu dengan pengada yang lain. Aplikasi dalam ilmu berupa komunikasi antar ilmuwan mutlak dibutuhkan, tidak hanya antar ilmuwan sejenis, tetapi juga antar disiplin ilmu, sehingga memperkaya pemahaman atas realitas keilmuan. 


\section{Bab II}

\section{Filsafat Konvensional dan Filsafat Modern di Abad}

Kemajuan IPTek

\subsection{Makna Filsafat terhadap Ilmu Pengetahuan Konvensional}

Filsafat ilmu adalah bagian dari filsafat yang menjawab beberapa pertanyaan mengenai hakikat ilmu. Bidang ini mempelajari dasar-dasar filsafat, asumsi dan implikasi dari ilmu, yang termasuk di dalamnya antara lain ilmu alam dan ilmu sosial. Filsafat ilmu sangat berkaitan erat dengan epistemologi dan ontologi. Filsafat ilmu berusaha menjelaskan masalah-masalah seperti: apa dan bagaimana suatu konsep dan pernyataan dapat disebut sebagai ilmiah, bagaimana konsep tersebut dilahirkan, bagaimana ilmu dapat menjelaskan, memperkirakan serta memanfaatkan alam melalui teknologi; cara menentukan validitas dari sebuah informasi; formulasi dan penggunaan metode ilmiah; macam-macam penalaran yang dapat digunakan untuk mendapatkan kesimpulan; serta implikasi metode dan model ilmiah terhadap masyarakat dan terhadap ilmu pengetahuan itu sendiri yang tidak relevan, serta dapat memberikan jalan penjelasan yang dapat dipertanggungjawabkan kebenarannya (Vardiansyah, 2008).

Ilmu berusaha menjelaskan karakter alam yang sebenarnya dan bagaimana teori ilmu pengetahuan dapat menjelaskan fenomena yang terjadi di alam. Untuk tujuan ini, ilmu menggunakan bukti dari eksperimen, deduksi logis serta pemikiran rasional untuk mengamati alam dan individual di dalam suatu 
masyarakat. Salah satu konsep mendasar tentang filsafat ilmu adalah empirisme atau ketergantungan pada bukti. Empirisme adalah cara pandang yang menyatakan bahwa ilmu pengetahuan diturunkan dari pengalaman yang kita alami selama kehidupan. Pernyataan ilmiah berarti harus berdasarkan dari pengamatan atau pengalaman. Hipotesis ilmiah dikembangkan dan diuji dengan metode empiris, melalui berbagai pengamatan dan eksperimentasi. Setelah pengamatan dan eksperimentasi ini dapat selalu diulang dan mendapatkan hasil yang konsisten, hasil ini dapat dianggap sebagai bukti yang dapat digunakan untuk mengembangkan teori-teori yang bertujuan untuk menjelaskan fenomena alam (Amsal, 2003).

Salah satu model yang digunakan untuk membedakan antara ilmu dan bukan ilmu adalah konsep falsifiabilitas. Konsep ini digagas oleh Karl Popper pada tahun 1919-20 dan kemudian dikembangkan lagi pada tahun 1960-an. Prinsip dasar dari konsep ini adalah, sebuah pernyataan ilmiah harus memiliki metode yang jelas yang dapat digunakan untuk membantah atau menguji teori tersebut. Misalkan dengan mendefinisikan kejadian atau fenomena apa yang tidak mungkin terjadi jika pernyataan ilmiah tersebut memang benar (Vardiansyah, 2008)

Memahami sejarah perkembangan ilmu pengetahuan secara mudah, di sini telah dilakukan elaborasi dan klasifikasi atau pembagian secara garis besar. Berikut adalah uraian singkat dari masing-masing periode atau sejarah perkembangan ilmu pengetahuan dari masa ke masa. Jika pengetahuan lahir sejak manusia pertama diciptakan, maka perkembangannya sejak jaman purba. Secara garis besar dibedakan atas periodisasi sejarah perkembangan ilmu pengetahuan menjadi empat periode: pada zaman Yunani kuno, pada zaman Islam, pada zaman renaisans dan modern, dan pada zaman kontemporer.

Sedangkan George J. Mouly membagi perkembangan ilmu menjadi tiga 3 tahap yaitu animisme, ilmu empiris dan ilmu teoritis. Penjelaskan ini memberi penegasan bahwa manusia purba sudah mendapatkan beberapa hubungan yang bersifat empiris untuk mereka untuk mengerti keadaan dunia. Upaya masa awal pada bidang keilmuan dalam sejarah dilakukan oleh bangsa Mesir dimana banjir Sungai Nil sering terjadi di setiap tahun sehingga berkembang sistem almanak, geometri dan kegiatan survey.

George J. Mouly menjelaskan bahwa pada tahap animisme, manusia menjelaskan gejala yang ditemuinya dalam kehidupan sebagai perbuatan dewadewi, hantu dan berbagai makhluk halus. Pada periode inilah pola pikir mitosentris masih sangat kental mendasari pemikiran bangsa Yunani sebelum 
menjadi logosentris. Sebagai contoh, gempa bumi pada masa ini tidak dianggap fenomena alam biasa, tetapi menganggap Dewa Bumi yang sedang menggoyangkan kepalanya. Namun, ketika filsafat diperkenalkan, fenomena alam tersebut tidak lagi dianggap sebagai aktivitas jiwa, terapi aktivitas alam yang terjadi secara kualitas (Noeng, 2003).

Berdasarkan pada pola di atas diketahui bahwa proses pola berpikir manusia menghakimi mereka untuk menemukan sebuah metode pembelajaran dari pengalaman dan memunculkan keinginan untuk menganalisis sesuatu hal secara empiris, jelas, dan diukur. Sejarah mencatat bangsa Yunani Lah yang pertama diakui oleh dunia sebagai perintis terbentuknya ilmu karena telah berhasil menyusun kerangka berpikir secara sistematis. Implikasi dari hal ini manusia senantiasa mencoba menganalisis semua hal termasuk asal-muasal mitos-mitos karena mereka sadar bahwa hal tersebut dapat menjelaskan asal usulnya dan kondisi yang sebenarnya. Sehingga suatu hal yang tidak jelas seperti hanya berupa tahu dan atau pengetahuan kemudian dapat dibuktikan kebenarannya dan dapat dipertanggungjawabkan pada saat itu. Dari sinilah awal kemenangan ilmu pengetahuan atas mitos-mitos, dan kepercayaan tradisional yang berlaku di masyarakat ((Koento, 2005).

Pondasi yang ditanamkan oleh bangsa Yunani maka ilmu pengetahuan menjadi pegangan yang kokoh bagi para pemikir untuk mengembangkan segala bentuk ilmu pengetahuan. Terlepas dari sebagian dari setiap periode yang melakukan penolakan atau perlawanan karna masi berpegang pada mitos dan dogma agama yang tidak bisa dipertanggungjawabkan. Dengan semakin berkembangnya ilmu pengetahuan tentunya perubahan budaya, cara pandang, dan lingkungan masyarakat semakin modern dari masa sebelumnya sehingga pemikiran manusia semakin terstruktur dan semakin banyak mendapatkan kemudahan dalam menghadapi segala tentang kehidupan.

Perkembangnya ilmu pengetahuan kalangan pemikir intelektual membutuhkan wadah untuk mengembangkan ilmu pengetahuan tersebut sehingga, bermunculan komunitas, Lembaga kajian, laboratorium yang awalnya masih sangat sederhana. Kebutuhan akan pentingnya wadah pentingnya regenerasi untuk mengembangkan ilmu pengetahuan maka dibentuklah Lembaga pengembangan ilmu pengetahuan yang lebih modern mulai dari abad 13, seperti Lembaga kajian, sekolah, universitas dan wadah lainnya yang yang disesuaikan dengan kebutuhan di era tersebut (Besari, 2008). 


\subsection{Makna Filsafat terhadap Ilmu Pengetahuan Modern}

Berbicara tentang filsafat ilmu, muncul pertanyaan pada diri sendiri, sejauh mana cabang filsafat ini mempunyai makna dan relevansi dengan masalahmasalah praktis yang perlu dipastikan kebenaran dan mendesak, yang menuntut penyelesaian secara praktis. Mengetahui tentang filsafat harus melihat dari segala sudut pandang perkembangan filsafat Ilmu dan juga proses perjalan perkembanganya. Adapun gambaran sederhana beberapa aspek filsafat terhadap ilmu pengetahuan diuraikan sebagai berikut;

\subsubsection{Ilmu Filsafat}

Menurut sejarah ilmu filsafat berbeda dengan filsafat ilmu. Ilmu filsafat berarti filsafat sebagai cabang ilmu, sedangkan filsafat ilmu berarti filsafat mewarnai seluruh disiplin keilmuan. Filsafat sebagai ilmu tidak jauh berbeda dengan cabang-cabang ilmu pengetahuan yang lainnya. Yang artinya memiliki sistematika sebagai berikut: (1) Gegenstand, yaitu suatu objek sasaran untuk diteliti, dipahami prosesnya, dan diketahui untuk menuju suatu pengetahuan, kenyataan, atau kebenaran, (2) Terus menerus menimbulkan pertanyaan tanpa henti, (3) Setelah itu ada alasan atau motif tertentu, dan dengan cara tertentu mengapa Gegenstand terus-menerus dipertanyakan. (4) Rangkaian dari jawaban yang dikemukakan kemudian disusun kembali ke dalam satu kesatuan sistem (Zubair, 2002).

Koento Wibisono, ilmu filsafat adalah ilmu menunjukkan kita bagaimana upaya manusia yang tidak pernah menyerah untuk menentukan kebenaran atau kenyataan secara kritis, mendasar, dan integral. Pandangan filsafat menyakut proses yang dilalui adalah refleksi, kontemplasi, abstraksi, dialog, dan evaluasi menuju suatu sintesis. Ilmu filsafat (filsafat sebagai ilmu) mempertanyakan hakikat (substansi) atau "apanya" dari objek sasaran yang dihadapinya dengan menempatkan suatu objek pada kedudukannya secara utuh. Hal ini sangatlah berbeda dengan ilmu-ilmu cabang yang lain, yang hanya melihat sesuatu pada satu titik pandang saja. Ilmu filsafat dalam memastikan objek material manusia, yang ingin dicari ialah hakikat manusia itu, apa makna kehadirannya serta tujuan hidup baik dalam arti imanen maupun transenden. Dengan melihat objek material manusia hanya pada satu sisi atau dimensi saja, ilmu-ilmu cabang 
tumbuh menjadi ilmu sosiologi, antropologi, psikologi, hukum, ekonomi, politik, dan lain-lainnya (Muntansyir, 2006).

\subsubsection{Filsafat Ilmu (Barat)}

Zaman modern, terasa adanya ketidak jelasan mengenai batasan antara (cabang) ilmu yang satu dengan yang lain, hingga interdependensi dan interelasi ilmu jadi sangat dibutuhkan. Atau bahkan terjadi sebaliknya, antara ilmu pengetahuan yang satu dengan yang lainnya saling terpisah secara dikotomis tanpa adanya kemauan untuk saling mengetahui sehingga diperlukan overview untuk meletakkan jaringan interaksi atau keterhubungan agar berbagai disiplin ilmu bisa bersinergi sehingga hakikat ilmu yang integral dan integratif. Dari sini membuka mata kita bahwa Kehadiran etika dan moral tentunya semakin dirasakan pentingnya. Sikap pandang bahwa ilmu adalah bebas nilai semakin ditinggalkan. Eksistensi dan integritas seorang ilmuwan kini sedang diuji.

Perkembangan perjalanannya kemudian, timbul kebutuhan untuk mengembangkan filsafat ilmu (philosophy of science), yang memang sangatlah penting dalam memberikan nilai atau aksiologi terhadap perkembangan dan kemajuan ilmu pengetahuan dan teknologi dimana tidak kalah pentingnya untuk memberikan batas-batas keilmuan agar tidak lebih jelas. Belakangan ini filsafat ilmu juga digalakkan di kalangan beberapa perguruan tinggi atau program studi demi menghadapi implikasi-implikasi-baik positif maupun negatifperkembangan ilmu pengetahuan bagi kehidupan umat manusia (Surajiyo, 2008)

Filsafat sebagai ilmu kritis, diharapkan berperan sebagai dasar dan arah dalam penyelesaian masalah-masalah fundamental di bidang sosial, ideologi, politik, ekonomi, pendidikan, dan lain-lainnya. Selain itu, filsafat ilmu diharapkan bisa menjadi mitra dialog dan sarana kritik terhadap kemajuan ilmu pengetahuan. Filsafat ilmu merupakan kelanjutan daripada epistemologi. Epistemologi merupakan pengetahuan yang mendasarkan diri pada sumber atau sarana tertentu seperti panca indera, akal (verstand), akal-budi (vernunft) dan intuisi. Dari situ berkembang berbagai macam school of thought, yakni rasionalisme (Descartes), empirisme (John Locke), kritisisme (Immanuel Kant), positivisme (August Comte), fenomenologi (Husserl), eksistensialisme (Sartre) konstruktivisme (Feyerabend), dan seterusnya. Hakikat ilmu yang merupakan tiang penyangga bagi eksistensi ilmu dan menjadi objek formal filsafat ilmu adalah ontologi, epistemologi, dan aksiologi. Ontologi ilmu meliputi hakikat 
ilmu, kebenaran, dan kenyataan yang inheren dengan pengetahuan ilmiah, yang tidak terlepas dari persepsi filsafat tentang sesuatu dan bagaimana yang "ada" itu. Paham Monisme yang terpecah menjadi idealisme/spiritualisme, materialisme, dualisme, pluralisme, dengan berbagai nuansanya, merupakan paham ontologi yang pada akhirnya menentukan pendapat bahkan "keyakinan" mengenai apa dan bagaimana (yang) "ada" sebagaimana manifestasi kebenaran yang dicari. Epistemologi ilmu meliputi sumber, sarana, dan tata-cara menggunakan sarana tersebut untuk mencapai pengetahuan ilmiah. Perbedaan mengenai pilihan landasan ontologik dengan sendirinya mengakibatkan perbedaan dalam menentukan sarana yang akan dipilih. Akal (verstand), akal budi (vernunft), pengalaman, atau kombinasi antara akal dan pengalaman, intuisi, merupakan sarana yang dimaksud dalam epistemologi, sehingga dikenal adanya model-model epistemologi seperti rasionalisme, empirisme, kritisisme dan rasionalisme kritis, positivisme, fenomenologi, eksistensialisme, konstruktivisme (Nadiroh, 2018).

Aksiologi ilmu meliputi nilai-nilai (values) yang bersifat normatif dalam pemberian makna terhadap kebenaran atau kenyataan sebagaimana dijumpai dalam kehidupan yang menjelajahi berbagai kawasan, seperti, kawasan sosial, simbolik, atau fisik-material. Lebih Dari itu nilai-nilai juga ditunjukkan oleh aksiologi sebagai suatu "conditio sine quanon" yang wajib dipatuhi dalam kegiatan manusia, baik dalam melakukan penelitian maupun dalam penerapan ilmu. Sementara itu objek material dari filsafat ilmu adalah segala ilmu pengetahuan.

\subsubsection{Filsafat Ilmu (Islam)}

Filsafat ilmu dalam Islam di kengenal tiga aliran besar; bayani (telaah teks), irfani (rasio-intuisi), dan burhani (empiri). Paradigma filsafat ilmu Islam membentang dari empirik-sensual, empirik-logik, empirik-etik, dan empiriktransendental. Filsafat ilmu Barat tidak menyentuh dataran empiriktransendental.

Kasanah ilmu dalam Islam, oleh Noeng Muhadjir disebut dengan non-tasyri' atau cum scientific (dalam bahasa Mukti Ali). Hal ini meliputi tajdid dan ijtihad atau usaha pembaharuan. Ini bisa berupa pembuatan telaah secara baik dalam wujud tafsir atau ta'wil dari wahyu pada persoalan yang bisa dijangkau akal; bukan persoalan yang ghaib seperti dzat Allah, sebab itu adalah urusan Allah, dan akal tidak dapat mencapai pemahaman yang baik, bahkan bisa mengarah 
pada kesesatan. Dalam bahasa Amin Abdullah, kawasan ilmu dalam Islam disebut dengan historisitas (Priadi, 2018).

Dalam perkembangannya, filsafat ilmu irfani menjurus dalam aksentuasi yang beragam. Irfani yang lebih menekankan intuisi berkembang ke ilmu kalam dengan telaah dialektik addalaalah (dalil-dalil), yang akhirnya menolak telaah filsafat. Irfani yang dikembangkan dalam fiqh mengarah ke telaah dialektika al'illah (argumentasi); mendialektikkan antara kata dan makna. Irfani dalam tafsir mengarah ke epistemologi lughawiyah (bahasa); membuat telaah tekstual dan menggunakan logika koherensi. Filsafat ilmu bayani menjadi aliran dominan dalam ulumuddin (ilmu-ilmu agama). Irfani berkembang secara beragam dan juga dominan dalam ulumuddin. Sementara burhani tidak begitu punya tempat untuk berkembang dalam ulumuddin.

Filsafat ilmu Barat menempatkan empiri sebagai sarana yang dominan. Rasio perlu tunduk pada bukti empirik. Pada zaman Rasulullah Saw. Banyak hal mengenai empiri menjadi landasan keputusan Rasul. Ketika Rasul menawarkan strategi perangnya, ada sahabat yang bertanya, apakah itu wahyu atau pendapat Rasul? Oleh karena itu pendapat Rasul maka Rasul menerima strategi yang ditawarkan oleh sahabat. Dikatakan bahwa Yunani merupakan induknya ilmu murni, sedangkan Islam adalah induk teknologi. Mengapa umat Islam sekarang memusuhi teknologi? Memang iptek dahulu adalah teistik, sedang iptek sekarang sekuler. Tugas ilmuwan Muslim adalah mengembalikan iptek menjadi teistik. Filsafat paripatetik (diskusi jalan-jalan) Yunani telah ditradisikan dalam filsafat Islam Andalusia, yang corak kerjanya dengan metode eksperimental dengan pembuktian logika matematika-korespondensi. Dapat dibayangkan bagaimana rumitnya matematika bila menggunakan angka lain selain Arab (Maharani, 2019).

Arti angka 0 memecahkan arti filsafat spekulatif Yunani; tidak ada yang ada. Dengan demikian jalur tradisi keilmuan iptek sekarang adalah Yunani sebagai induk ilmu yang lebih konseptual teoritik. Sementara iptek yang saat ini berkembang dalam integrasi rasionalitas dengan kecermatan empirikeksperimental telah dirintis ilmuwan Islam Andalusia. Pertanyaanya, mengapa Islam tertinggal saat ini? Umat Islam telah memilih menyelamatkan hidup di akhirat dan meninggalkan dunia. Padahal Allah telah menjanjikan bahwa hidup di dunia memberikan kebaikan bagi yang beriman dan yang tidak beriman. Kehidupan akhirat memberikan kebahagiaan bagi yang beriman. 


\subsection{IPTek AbaD 13 dan Abad ke 10}

Michelet, sejarawan terkenal, adalah yang pertama menggunakan istilah renaisans. Para sejarawan biasanya memakai istilah ini dalam menunjukan berbagai periode kebangkitan intelektual, pada khususnya di Eropa, dan lebih khusus lagi di Italia sepanjang abad ke-15 Masehi dan ke-16 Masehi. Agak sulit menentukan garis batas yang jelas antara abad pertengahan, zaman renaisans, dan zaman modern. Sementara orang menganggap bahwa zaman modern hanyalah perluasan dari zaman renaisans (Shinta, 1991).

Renaisans adalah periode perkembangan peradaban yang terletak di ujung atau sesudah abad kegelapan sampai muncul abad modern. Renaisans merupakan periode sejarah yang penuh dengan kemajuan dan perubahan yang mengandung arti bagi perkembangan ilmu. Ciri utama renaisans yaitu humanisme, individualisme, sekulerisme, empirisme, dan rasionalisme. Sains berkembang karena semangat dan hasil empirisme, sementara Kristen semakin ditinggalkan karena semangat humanisme.

Pengaruh ilmu pengetahuan Islam terhadap Eropa yang sudah berlangsung sejak abad ke-11 Masehi itu menimbulkan gerakan kebangkitan kembali (renaissance) pusaka Yunani di Eropa pada abad ke-14 Masehi. Berkembangnya pemikiran Yunani di Eropa kali ini adalah melalui terjemahanterjemahan Arab yang dipelajari dan kemudian diterjemahkan kembali ke dalam bahasa Latin. Walaupun Islam akhirnya terusir dari negeri Spanyol dengan cara yang sangat kejam, tetapi ia telah mendasari gerakan-gerakan penting di Eropa. Gerakan-gerakan itu adalah kebangkitan kembali kebudayaan Yunani klasik (renaissance) pada abad ke-14 Masehi, rasionalisme pada abad ke-17 Masehi, dan pencerahan (Aufklarung) pada abad ke-18 Masehi.

Perkembangan ilmu pengetahuan dan juga ilmu sosial dengan pendekatan empiris, mencapai bentuknya secara definitif dengan kehadiran Auguste Comte (1798-1857) dengan grand-theory-nya yang digelar dalam karyanya Cours de Philosophie Positive yang mengajarkan bahwa cara berpikir manusia, juga masyarakat di mana pun akan mencapai puncaknya pada tahap positif, setelah melalui tahap teologik dan metafisik. Istilah positif olehnya diberi arti eksplisit dengan muatan filsafati, yaitu menerangkan bahwa yang benar dan yang nyata haruslah konkret, eksak, akurat, dan memberi kemanfaatan (George, 1991).

Metode observasi, eksperimentasi, dan komparasi yang dipelopori Francis Bacon (1561-1616) juga ikut mendorong pesatnya perkembangan ilmu pengetahuan, dimana para ilmuwan setelahnya seperti Helmholtz, Pasteur, 
Darwin, Clerk Maxwell, berhasil menemukan hal-hal yang baru dalam penelitian ilmiahnya. Kesemuanya itu memberi isyarat bahwa dunia Barat telah berhasil mendasari petualangan ilmu pengetahuan yang tak berujung.

Battle Cry-nya Francis Bacon yang menyatakan bahwa "knowledge is power" bukan sekedar mitos, melainkan sudah menjadi etos. Hal itu telah melahirkan corak dan sikap pandang manusia yang meyakini kemampuan rasionalitasnya untuk menguasai dan memperkirakan masa depan, dan dengan optimismenya, berinovasi secara kreatif untuk membuka rahasia-rahasia alam. Semenjak itu masyarakat Barat menjadi masyarakat yang tiada hari tanpa temuan-temuan baru yang muncul secara historis, kronologis, berurutan, dan berdampingan sebagai alternatif (Amsal, 2013).

"Revolusi" ilmu pengetahuan telah berlanjut di abad ke-10 Masehi berkat teori relativitasnya Einstein yang telah merombak filsafat Newton yang semula dianggap sudah mapan, disamping teori kuantumnya yang telah mengubah persepsi dunia ilmu pengetahuan tentang sifat-sifat dasar dan perilaku materi sedemikian rupa sehingga para pakar dapat melanjutkan penelitianpenelitiannya, dan berhasil mengembangkan ilmu-ilmu dasar seperti astronomi, fisika, kimia, biologi molekuler, sebagaimana hasilnya dapat "dinikmati" oleh manusia di abad ke-11 Masehi sekarang ini.

Dalam menghadapi kemajuan ilmu pengetahuan dengan temuan-temuan spektakulernya, rasa optimisme disamping pesimisme merupakan sikap manusia masa kini yang di satu pihak telah meningkatkan fasilitas hidup, yang berarti menambah kenikmatan; namun di pihak lain gejala-gejala adanya dekadensi moral kemanusiaan menjadi semakin meningkat dengan akibatakibat yang cukup fatal.

Secara historis, persaingan besar sumber pengetahuan yang menunjang kemajuan ilmu pengetahuan di era sekarang, bermula dari Rasionalisme dengan tokohnya Rene Descartes, Empirisme juga dengan tokohnya John Locke, dan kritisisme juga dengan tokohnya Immanuel Kant. Pergulatan tersebut kemudian berpuncak pada pemikiran August Comte dengan aliran Positivisme-nya. Abad ke-19 Masehi bisa dibilang sebagai abad Positivisme karena begitu kuat dan luasnya pengaruh aliran ini di abad modern. Ukuran kebenaran ukur dari sudut positivistik-nya. Filsafat menjadi praktis bagi tingkah laku perbuatan manusia sehingga tidak lagi memandang penting berpikir abstrak (Karim, 2014.

Perkembangan kebudayaan dalam beberapa abad terakhir ini begitu cepat, di samping karena pertambahan penduduk, pengaruh utama justru dari 
perkembangan ilmu pengetahuan dan teknologi yang sangat pesat. Dalam sejarah masyarakat kuno, manusia hidup sebagai pemburu dan peramu dengan perkembangan kebudayaannya yang lambat. Perkembangan peradaban kemudian terakumulasi oleh akumulasi dan interaksi antara pengolahan, dengan adanya revolusi pertanian dan sesudah mereka hidup dalam jumlah yang besar dan menetap, serta dengan timbulnya kota dan tulisan. Teknologi memegang peranan penting, terutama dengan revolusi industri, perkembangannya mulai terpacu lagi (Nafiur, 2018).

Abad 20 mencatat loncatan-loncatan penting dalam perkembangan ilmu pengetahuan dan teknologi. Penemuan dan penciptaan silih berganti dan berkelanjutan, sedangkan informasi ilmiah diproduksi dengan cepat setiap lima tahun, bahkan dalam disiplin-disiplin tertentu seperti genetika setiap dua tahun, sehingga menimbulkan kesukaran dalam penyebaran, penyimpanan, penelusuran dan penyerapannya. Semua itu pada gilirannya memerlukan teknologi. Di era inilah mulai tersebar luas cabang-cabang biologi yang inovatif dan revolusioner, serta cabang-cabang fisika, kimia dan geologi yang membuka cakrawala baru bagi kehidupan manusia.

Jarak antara teori dan praktek, gagasan dan penciptaan, laboratorium dan pasar semakin dekat. Ciptaan mempengaruhi gagasan, dan teknologi mempengaruhi ilmu. Laju teknologi komunikasi juga semakin pesat, sehingga hasil ilmu pengetahuan dan teknologi dengan cepat menyebar di masyarakat. Kegelisahan yang ditimbulkan oleh perubahan semacam ini, kerap mengakibatkan keresahan dikalangan masyarakat (Sulhatul, 2017).

Revolusi dalam ilmu pengetahuan dan teknologi berkali-kali telah terjadi, dengan akibat yang besar dan tidak terduga. Perkembangan empat revolusi dimaksud sebagai berikut: Revolusi pertama, membuka era bagi penelitian mendalam tentang gaya gravitasi, dan penelitian tentang dinamika pergerakan benda-benda. Hasil dari penelitian tersebut membuahkan hasil penemuan yang sangat monumental dan menjadi ujung tombak peradaban. Era tersebut dirintis oleh Isaac Newton. Revolusi kedua, era ini lebih memusatkan pada sifat-sifat teknologi kelistrikan dan kemagnetan yang mengamati seluruh benda-benda, dan juga tentang sifat-sifat dengan penelitian radiasi. Perkembangan ilmu pengetahuan dalam era tersebut dipelopori oleh beberapa sarjana-sarjana besar seperti Faraday, sedangkan deskripsi teoritisnya oleh Maxwell.

Revolusi ketiga, era yang diawali pada ditemukannya sifat kuantum cahaya oleh Max Planck. Era ini membawa revolusi secara menyeluruh yang merubah paradigma berpikir manusia tentang kajian zat dan jagad raya. Kecemerlangan 
era ini dikembangkan oleh Einstein yang menemukan Teori Relativitas; Rutherford tentang atom; Bohr tentang kuantum dan nama-nama yang berkaitan dengan teori kuantum baru seperti Schrodinger, Heisenberg dan Dirac. Revolusi keempat dimulai pada tahun 1938 dengan ditemukannya suatu tipe materi baru yang disebut partikel oleh Anderson (Nafiur, 2018).

Dalam teknologi yang lebih maju dalam revolusi industri melahirkan terciptanya mesin uap, yang dimulai oleh bangsa Eropa Barat dan akhirnya menjalar ke seluruh dunia sehingga seluruh industrialisasi menjadi komersialisasi yang digunakan dalam seluruh aspek kehidupan masyarakat. Revolusi kedua disebabkan oleh Taylorisme pada awal abad XX dengan roda berjalan di pabrik yang mengubah sistem kerja manual dan atau pekerjaan industri yang dominan menggunakan tenaga kerja tergantikan. Revolusi ketiga dengan mikroelektronik yang mulai melanda dunia tahun 1960-an dan terus berkembang sejalan dengan berjalannya waktu yang melahirkan inovasi dengan kejutan besar di masa mendatang. Dalam ilmu alam yang ekstrim dan eksak, terjadi pergeseran mulai dari pandangan yang statis ke dinamis, dari kepastian menjadi ketidakpastian. Segala sesuatu berubah dan relatif, objektivitas dan netralitas ilmu menjadi tidak mutlak, dalam segala kenyataan dalam alam, sehingga waktu dan proses pengembangan memegang peranan penting untuk kedepannya.

Selanjutnya penemuan dalam hal media komunikasi yaitu mesin pencetak menjadi penemuan yang sangat lah penting, yang dimanfaatkan sangat baik dimana pertama kali di Eropa. Perkembangan dan Penyebaran informasi melonjak dengan sangat luar biasa. Media elektronik kemudian berevolusi dengan informasi dengan televisi, koran jarak jauh (Tele Zeitung) dan lain-lain sebagainya, sehingga dunia menjadi sangat sempit. Pada zaman sekarang ini mikroelektronik dan multimedia membawa masyarakat dunia masyarakat informasi yang mampu menyajikan gambar, suara dan gerakan sekaligus dan menjadikan manusia bersifat individual dan personal (Karim 2014).

Ilmu pengetahuan yang terus semakin maju, mengubah masyarakat dari cara pertanian, berladang, dan beternak tradisional menjadi lebih maju dengan bantuan ilmiah dengan kehidupan kota dan komunikasi yang padat. Ilmu pengetahuan yang berkembang sangat pesat itu terjadi di seluruh dunia dengan laju, pola dan waktu yang berbeda-beda sehingga timbul mozaik di dalam lingkaran ruang dan waktu. Tidak ada pemodelan dasar yang identik bagi perkembangan seluruh kebudayaan dan pada setiap masa, kecuali pada garisgaris besar yang mendasar, karena batasnya kemungkinan yang dapat ditempuh. 
Kehidupan manusia yang berubah ke pola ilmiah juga dapat menggiring manusia pada peradaban yang selangkah demi selangkah lebih maju, dibarengi dengan teknologi-teknologi yang semakin modern (Shinta, 2019).

\subsection{Implikasi Filsafat Terhadap Ilmu Pengetahuan}

Filsafat ilmu sangat diperlukan kehadirannya di tengah perkembangan Iptek (ilmu dan teknologi) yang ditandai semakin membuminya spesialisasi ilmu pengetahuan. Sebab dengan mempelajari filsafat ilmu, maka para ilmuwan akan sadar atas keterbatasan dirinya dan tidak terjebak ke dalam sikap arogansi intelektualnya. Hal yang penting lain yang diperlukan adalah keterbukaan diri dikalangan ilmuwan, sehingga mereka dapat saling menyapa dan mengerahkan seluruh potensi keilmuan yang dimilikinya untuk kepentingan umat manusia.

Filsafat ilmu sebagai cabang khusus filsafat yang membahas tentang sejarah perkembangan ilmu. Metode-metode ilmiah, sikap etis yang harus dikembangkan para ilmuwan secara umum mengandung tujuan-tujuan sebagai berikut:

Pertama, filsafat ilmu sebagai sarana pengujian penalaran ilmiah, sehingga orang menjadi kritis terhadap kegiatan ilmiah. Seorang ilmuwan harus memiliki sikap kritis terhadap bidang ilmunya sendiri, sehingga dapat menghindarkan diri dari sikap solipsistik, menganggap bahwa hanya pendapatnya yang paling benar.

Kedua, filsafat ilmu merupakan upaya merefleksi, menguji, mengkritik asumsi dan metode keilmuan. Kecenderungan yang terjadi oleh kalangan para ilmuwan modern adalah penerapan suatu metode ilmiah tanpa memperhatikan struktur ilmu pengetahuan itu sendiri. Satu sikap yang diperlukan di sini adalah implementasi metode ilmiah yang sesuai dengan struktur ilmu pengetahuan, bukan sebaliknya. Metode hanya sarana berpikir, bukan merupakan hakikat ilmu pengetahuan (Maharani, 2019).

Ketiga, filsafat ilmu memberikan pendasaran logis terhadap metode keilmuan. Setiap metode ilmiah yang dikembangkan tentunya harus dipertanggungjawabkan secara logis-rasional, untuk dapat dipahami dan diterapkan secara umum. Semakin terbuka penerimaan dan penggunaan metode 
ilmiah, maka semakin akurat metode tersebut, penggunaan kajian tersebut digunakan dalam metodologi, dalam hal ini ilmu yang mempelajari tentang tata cara atau pemodelan untuk memperoleh kebenaran.

Adapun implikasi filsafat ilmu terhadap perkembangan ilmu pengetahuan ;

1 sebagai seorang ilmuwan diperlukan pengetahuan dasar yang kuat tentang metode ilmu, baik dari segi keilmuan alam maupun ilmu sosial, agar para ilmuwan memiliki landasan pikir yang kuat. Hal ini memberikan gambaran pada para ilmuwan sosial perlu mempelajari ilmu-ilmu kealaman secara garis besar, demikian pula seorang ahli ilmu kealaman perlu memahami dan mengetahui secara garis besar tentang ilmu-ilmu sosial. Sehingga antara ilmu yang satu dengan lainnya saling bersinergi, bahkan diharapkan terjalinnya kerja sama yang harmonis untuk memecahkan persoalanpersoalan kemanusiaan.

2 Membuka mata para ilmuwan agar tidak terjebak ke dalam pola pikir "Menara Gading" yakni berpikir terlalu arogan dalam bidangnya tanpa mengaitkannya dengan kenyataan yang ada di luar dirinya. Padahal setiap aktivitas keilmuan nyaris tidak dapat dilepaskan dari konteks kehidupan sosial-kemasyarakatan.

Masalah dari pengembangan ilmu pengetahuan dan teknologi membutuhkan dimensi etis sebagai pertimbangan dan kadang-kadang mempunyai pengaruh pada proses perkembangan lebih lanjut terhadap ilmu pengetahuan dan teknologi bentuk Tanggung jawab etis harus menjadi suatu dasar dalam penggunaan ilmu pengetahuan dan teknologi. Ilmuwan dalam mengembangkan ilmu pengetahuan dan teknologi harus memperhatikan kodrat manusia, martabat manusia, menjaga keseimbangan ekosistem, bertanggung jawab pada kepentingan umum, kepentingan generasi mendatang, dan bersifat universal. Pada dasarnya ilmu pengetahuan dan teknologi adalah untuk mengembangkan dan memperkokoh eksistensi manusia bukan untuk menghancurkan eksistensi manusia (Priadi, 2018).

Tanggung jawab ilmu pengetahuan dan teknologi menyangkut juga tanggung jawab terhadap dampak atau sesuatu diakibatkan ilmu pengetahuan dan teknologi di masa-masa lalu, sekarang maupun akibatnya bagi masa depan berdasar aktivitas perkembangan manusia kedepan. Penemuan-penemuan baru dalam ilmu pengetahuan dan teknologi menjadi pembukti yang dapat mengubah suatu aturan baik alam maupun manusia. Hal ini tentu saja menuntut tanggung jawab untuk selalu menjaga dan terwujudnya perubahan yang mengarah ke hal 
terbaik bagi perkembangan ilmu pengetahuan dan teknologi itu sendiri, maupun bagi perkembangan eksistensi manusia secara utuh.

Tanggung jawab etis tidak hanya menyangkut proses pengembangnnya tapi juga penerapan ilmu pengetahuan dan teknologi menjadi jalur yang tepat dalam kehidupan manusia. Manusia harus sadar apa yang seharusnya dikerjakan atau tidak dikerjakan untuk memperkokoh kedudukan serta martabat manusia yang seharusnya, baik dalam hubungannya sebagai pribadi, dengan lingkungan, dan sebagai makhluk yang bertanggung jawab terhadap Khaliknya (Nadiroh, 2018).

Jika melihat dari berbagai dampak negatif dari perkembangan teknologi, maka sangat diperlukan kendali etik terhadap perkembangan teknologi modern, untuk mencegah proses degeneratif berlanjut. Jacob berpendapat bahwa usaha-usaha yang dapat dilakukan untuk meredam pengaruh negatif tersebut antara lain adalah:

1. Rehumanisasi

Mengembalikan martabat manusia untuk pengendalian perkembangan teknologi modern yang sangat begitu cepat dengan berbagai cara. Kecepatan perkembangan teknologi seharusnya disesuaikan dengan peningkatan populasi manusia sebagai pengguna ilmu dan teknologi tersebut. Pendidikan seyogyanya tidak berat sebelah, terutama pada tingkat tersier: nilai tidak dapat dipisahkan dari keterampilan. Keterampilan baru memerlukan etika baru, karena perkembangan nilai-nilai agama, etika, hukum dan kebijakan lebih lambat dari pada perkembangan teknologi, maka masalah ini harus mendapat perhatian khusus. Dalam peningkatan hidup manusia, tidak hanya kualitas ekstrinsik yang perlu mendapat perhatian, tetapi juga kualitas intrinsik.

2. Kemampuan memilih

Etika seharusnya menentukan arah bahwa apa yang mungkin diteliti dan dikembangkan tidak dapat dilakukan jika tidak manusiawi, maka segala yang teknis mungkin akan dikerjakan, tidak dipertentangkan dan menjadi filter demi menjaga nilai-nilai kemanusiaan.

3. Arah perkembangan kemajuan 
Tentunya utamanya arah perkembangan kemajuan nasional, bahkan internasional diperlukan etika untuk memastikan keadilan sosial internasional dan hak asasi bangsa-bangsa.

4. Revitalisasi

Diperlukan daya dan upaya positif untuk mencegah distorsi biokultural yang berkelanjutan. Pembangunan pada akhirnya akan menuju ke suatu kebudayaan baru di masa yang akan datang. Persiapan-persiapan harus menyeluruh, kode-kode harus jelas dan dipegang teguh dalam kehidupan sehari-hari, terus diadaptasi dan diseminasi seluas mungkin dalam berbagai lingkungan dengan berbagai media.

\subsection{Relevansi Filsafat terhadap IPTek}

Pertumbuhan ilmu dan teknologi saat ini sangat pesat dimana dampaknya amat besar terhadap kehidupan setiap orang. Sehingga boleh dikatakan saat ini telah masuk di setiap segi dan aktivitas kehidupan seseorang telah tersentuh oleh kemajuan ilmu dan perkembangan teknologi. Ilmu dan teknologi bukanlah entitas yang sederhana karena berkaitan erat dengan dorongan hakiki dan naluri kreatif dalam diri manusia. Bagaimana hubungan antara ilmu dengan teknologi yang saling-kait, saling menunjang dan saling mempengaruhi antara satu dengan yang lainnya (Zubair, 2002).

Ilmu dan teknologi jika dikaji dari berbagai aspek sudut pandang dan nuansanya maka ada titik singgung antara keduanya, yakni:

1. Baik ilmu dan teknologi merupakan komponen dari kebudayaan;

2. Baik ilmu dan teknologi memiliki aspek ideasional maupun faktual, dimensi abstrak maupun konkret, dan aspek teoritis maupun praktis.

Terdapat hubungan dialektis antara ilmu dan teknologi. Pada satu sisi, ilmu menyediakan bahan pendukung penting bagi kemajuan teknologi yakni berupa teori-teori. Pada sisi lain penemuan teknologi sangat membantu hasanah cakrawala penelitian ilmiah.

\subsubsection{Dampak Teknologi Terhadap Manusia}


Teknologi merupakan buah karya manusia untuk mengolah lingkungan dan menyesuaikan diri dengan lingkungannya tersebut. Teknologi juga menjadi instrumen bagi manusia dalam memenuhi kebutuhan hidup, tidak hanya kebutuhan dasarnya yaitu pangan, mobilitas, komunikasi serta pertahanan keamanan, tetapi juga kebutuhan untuk meningkatkan mutu kehidupannya (quality of life). Teknologi menjadi suatu subjek krusial atas penguasaannya.

Manusia dan lingkungan mempunyai hubungan Simbiosis Mutualisme, karena manusia dipengaruhi oleh lingkungan, maka lingkungan teknologi juga mempunyai dampak terhadap manusia. Teknologi awal yang sederhana, seperti teknologi kayu, batu dan tulang, sedikit jumlahnya dan lambat tumbuhnya, sehingga pengaruhnya terhadap manusia tidak segera muncul. Teknologi mutakhir yang berkembang secara masif, dengan laju yang cepat, dan dampaknya terhadap manusia juga luas dan mendalam. Walaupun dampaknya dari segi penerimaan beragam tergantung sumber daya dan keinginan untuk mendapatkanya (Priadi, 2018).

Jacob berpendapat bahwa ada tujuh dampak negatif teknologi terhadap manusia dapat disebutkan sebagai berikut:

1. Pergeseran atau pergantian manusia (displacement, substitution)

Misalnya, fungsi otot-otot besar manusia yang di dalam pekerjaannya diganti oleh hasil teknologi, sehingga manusia mengalami atrofi.

2. Kebebasan terkekang

Pilihan yang dapat diambil manusia relatif makin sedikit, meskipun dapat makin bertambah dengan perkembangan teknologi. Makin banyak hal yang dapat dibuat, tetapi keinginan manusia yang dapat dicapai hanyalah sedikit. Manusia dalam banyak hal harus menyesuaikan diri dengan alat-alat dan sistem.

3. Kepribadian terhimpit

Manusia cenderung terdesak menjadi manusia massa yang uniform dengan privacy yang makin kurang. Ia menjadi bagian kecil dari perencanaan sentral dan ia harus berpartisipasi di dalamnya.

4. Objektivitas manusia (dehumanisasi) 
Manusia dianggap sebagai hal yang objektif, diurai-urai, hanya hal-hal yang dapat diukur atau dihitung saja yang dapat diperhatikan, sedangkan yang lain-lain dianggap periferal dan tidak menjadi perkembangan dalam usahausaha pengembangan, pendidikan dan penigkatannya. Teknologi semakin berkembang menjadi sistem yang rumit dan mahal, serta makin otonom, karena tidak ada orang yang dapat menghambatnya. Teknologi juga membiarkan diri, dan manusia hanya menjadi jentera atau budaknya yang efisien.

5. Mentalitas teknologis

Hal ini tercermin pada kepercayaan yang berlebihan pada alat (etnosentris), seolah-olah segala sesuatu dapat dipecahkan oleh teknologi, dan sesuatu akan lebih meyakinkan kalau dilakukan dengan peralatan dan disertai angkaangka.

6. Penyeimbangan kembali yang tidak adaptif

Dalam rangka mengembalikan keseimbangan yang terganggu oleh teknologi, orang kadang-kadang lari ke penggunaan obat-obatan untuk adaptasi seperti narkotika, psikedelik dan lain-lain dan mencari kekuatan dengan mengumpulkan barang-barang penunjuk status (positional goods) untuk mengkompensasi adaptasi yang gagal.

7. Krisis teknologis

Berbagai krisis yang melanda dunia di abad ini terutama disebabkan oleh perkembangan teknologi yang terlalu cepat, sehingga proses adaptasi dan integrasi tidak sempat dilakukan. Akibat dari proses adaptasi dan integrasi yang tidak sempat dilakukan maka berakibat pada individu adalah technostress, penyakit urban, penyakit peradaban dan lain-lain. Sistem dalam stress pasti menunjukkan patologi. Teknologi destruktif juga berkembang dengan pesat dan kontinu dalam bentuk perlombaan senjata nuklir, yang membuat perang menjadi usang sebagai cara pemecahan konflik (Besari, 2008).

\subsubsection{Dampak Teknologi Terhadap Lingkungan}

Adapun dampak teknologi terhadap lingkungan, antara lain: 
1. Terkurasnya sumber daya. Teknologi cenderung berkembang ke arah penciptaan kebutuhan baru, hiperkonsumsi, maka eksploitasi sumber daya semakin meningkat, terutama untuk memuaskan kebutuhan kultural.

2. Gangguan iklim. Tumbuhnya megalopolis dan kawasan industri dapat menimbulkan perubahan cuaca.

3. Pencemaran lingkungan dan dari dinamika kehidupan manusia untuk senantiasa hidup dalam kondisi yang ideal, sehingga mendorong timbulnya nafsu untuk merealisasikan atas segala hal yang menjadi kebutuhannya.

4. Destabilisasi dan dekompensasi lingkungan. Pada tahap-tahap terakhir akan terjadi dekompensasi, ketika alam tidak lagi dapat memelihara keseimbangan yang diperlukan karena hantaman teknologi yang terus menerus.

5. Beban-lebih informasi. Ketidakseimbangan informasi antara berbagai lapisan masyarakat dan diantara masyarakat akan melahirkan keteganganketegangan.

6. Konsumsi tinggi dan missal. Dinamika sosial ekonomi tidak bergerak seiring dengan peningkatan konsumsi, maka masyarakat Dunia Ketiga hanya menjadi konsumen barang-barang dari negeri mewah yang sebetulnya tidak sesuai dengan tahapan kemajuannya.

7. Destruksi dan kepunahan spesies hewan dan tumbuh-tumbuhan

8. Distorsi biokultural. Keadaan ini sebetulnya sedang berlangsung sekarang. Gejala-gejala pengembalian keseimbangan pribadi dalam berbagai bentuk yang patologis, seperti ketagihan obat-obatan sosial, kesulitan ekonomi, terbelinya petugas (venality of public officials), keresahan intelektual, perkosaan, perceraian, perlombaan senjata dan lain-lain yang sudah melembaga. Hal tersebut terutama disebabkan kemajuan yang sangat terakselerasi dari masyarakat pasca industri di Dunia Pertama. Sebaliknya usaha-usaha revitalisasi dan resensi memang tampak pula di sana-sini (Muntansyir, 2006). 


\section{Bab III}

\section{Filsafat Zaman Yunani}

\subsection{Filsafat Orang Yunani}

Filsafat Orang Yunani, merujuk pada pemahaman bahwa manusia dianggap sebagai mikrokosmos "dunia kecil" dalam komposisi "dunia besar" dari alam semesta. Pandangan filsafat ini bertumpu dari refleksi dan simbol alam semesta yang dipahami dari eksistensi manusia sebagai organisme spiritual. Karenanya, setiap orang dapat memahami bahwa dalam dirinya memiliki semua elemen dasar alam semesta. Organisme spiritual sebagai unsur penting dari manusiamenurut tradisi agama dikenal dengan jiwa atau roh, sedangkan dalam tradisi filsafat meminjam istilah Aristoteles (384-311 SM) seringkali diidentifikasi sebagai "jiwa yang berpikir" (animal rationale). Organisme spiritual inilah yang membedakannya secara prinsipil dengan makhluk selain manusia.1 Awalan ini menunjukkan bahasan tentang eksistensi manusia menjadi objek penting dalam penyelidikan pelbagai disiplin ilmu, termasuk filsafat dan agama (Latifah, 2016).

Eksistensi manusia dipahami sebagai suatu kesatuan organisme dari unsur biologis dan psikologis, atau alam dan sosial. Dalam kehidupannya, eksistensi manusia merupakan perjalanan yang mengikuti aturan-aturan biologi-fisiologis seperti adanya sirkulasi darah, kebutuhan terhadap nutrisi dan oksigen dalam 
tubuh, serta mengikuti sistem organisme hidup; lahir, dewasa, dan mati. Adapun dari fase eksistensi individu-psikologis, manusia mengalami proses pembentukan emosional sejak usia anak, dewasa hingga tua. Manusia disebut sebagai organisme yang memiliki sistem perkembangan paling kompleks dibanding dengan makhluk hidup lainnya. Selain itu, tingkat kecerdasan yang tinggi juga menempatkan manusia sebagai titik pusat dari semua bentuk gerak materi yang ada di alam semesta, sehingga manusia diyakini telah diberkati oleh tuhan dengan kekuatan dasar dari alam. Manusia semenjak lahir, eksistensi individual dipercaya mempunyai keterhubungan dengan alam semesta. Tidak heran jika manusia disebut sebagai mikrokosmos karena keterwakilan, eksistensi dan keunikannya secara fisiologis dan psikologis sebagai bagian dari makrokosmos (Nur, 2015).

Socrates dan Plato melangkah lebih mendalam dengan melakukan kajian tentang alam kecil atau dunia kecil (mikrokosmos), yaitu manusia. Socrates (469-399 SM) menyebutkan bahwa tujuan tertinggi manusia adalah pada jiwanya (psikhe) agar menjadi sebaik mungkin. Tingkah laku manusia dapat disebut baik bila manusia dipandang dari fisiknya tidak hanya dari aspek lahiriah yang mencitrakan hal yang baik. Pernyataan ini mengantarkan pada kesimpulan bahwa tujuan hidup manusia adalah eudaimonia (kebahagiaan) yang bersemayam dalam dimensi batinnya, bukan yang tampak dari dimensi lahirnya. Sebab. Jika mengasuh filosofibangsa Yunani, eudaimonia berarti kesempurna-an atau lebih tepat lagi dikatakan bahwa eudaimonia berarti mempunyai daimon yang baik, dan yang dimaksud dengan daimon adalah jiwa.

Socrates Menyebutkan, manusia dapat mencapai eudaimonia atau kebahagiaan dengan arête (moral virtue). Arete Adalah keutamaan seorang berdasarkan kodrat untuk diciptakan. Seorang negarawan mempunyai arti yang memungkinkannya menjadi politi-kus yang baik. Seorang tukang sepatu yang mempunyai arti yang menyebabkan menjadi seorang tukang sepatu yang baik. Dengan aretekeduanyamendapat pengetahuan yang memungkinkannya menjadi seorang politikus atau tukang sepatu yang baik (Bahri, 2009).

Plato (417-347 SM), salah seorang murid Socrates menegaskan pandangannya bahwa manusia adalah makhluk yang terpenting diantara semua makhluk yang terdapat di dunia dan sebagaimana juga gurunya. Plato menganggap bahwa jiwa sebagai pusat atau intisari kepribadian manusia. Jiwa bersifat kekal dan sudah ada terlebih dahulu sebelum keberadaannya di dunia material dan fana yakni di alam lain yang disebut alam idea (ide). Kelahiran manusia di dunia membuat manusia lupa tentang alam ide sebelumnya. Meskipun pengetahuan dari alam 
ide itu terlupakan oleh manusia sejak ia lahir ke alam fana (dunia), tapi pengetahuan tentangnya tidak hilang sama sekali, pengetahuan tersebut tetap tinggal dalam jiwa manusia dan dapat diingatkan kembali dari proses hidup yang dijalani. Dengan demikian, pengetahuan manusia di dunia pada dasarnya adalah pengenalan kembali atau pengingatan (anamnesis) terhadap alam ide yang dulu pernah dikenalnya (Cikgenc, 1995).

Socrates dan Plato mencoba memahami manusia dalam kerangka berpikir sangat universal. Manusia dipandang oleh keduanya sebagai bagian dari makrokosmos yang disebut mikrokosmos. Sebagaimana manusia yang dipandang terdiri dari tubuh dan jiwa, maka alam semesta juga dipandang secara dualistik sebagai tubuh dan jiwa yang diciptakan oleh "sang tukang" (demiurgos) dalam postulat keduanya. Pada titik ini dapat dimengerti ciri khas dari pemikiran filsafat pada masa Yunani Kuno ketika melihat segala sesuatu sebagai satu kebenaran, maka para filsuf memikirkan segala sesuatu itu sebulatbulatnya (whole), termasuk tentang alam semesta. Cara berpikir serta pengetahuan yang mendasar dan universal semacam ini, diwarisi oleh Aristoteles murid Plato yang hidup pada tahun 384-311 SM dan belajar di akademi milik Plato yang menguasai sampai mendalam hampir segala ilmu yang diketahui pada masanya. Aristoteles adalah ahli dalam ilmu alam, hukum, etika dan lain-lain.4 Namun, antara guru dan murid itu terdapat silang pandang tentang hakikat terpisah atau menyatu antara tubuh dan jiwa (Adian, 2003).

Telah Diketahui di era filsafat Yunani Kuno ketertarikan filsuf terhadap alam lebih dominan daripada keingintahuan terhadap manusia, sehingga permasalahan tentang manusia yang kompleks belum dapat terpecahkan secara tuntas, melainkan hanya berkutat pada persoalan tubuh dan jiwa yang terdapat dalam diri manusia. Teori dualisme Plato tetap tidak memberikan pengaruh besar terhadap filosof setelahnya mengenai pembahasan tentang manusia. Demikian juga dengan Aristoteles yang memandang manusia serupa dengan entitas-entitas lain yang hidup di kosmos. Perenungan Aristoteles berhasil menetapkan kesatuan badan dan jiwa monisme yang menurut pandangan ini struktur kodrat manusia mirip entitas-entitas lainnya di dunia, sehingga jiwa manusia pun harus diakui sebagai morphe (bentuk atau rupa). Namun demikian, tetap saja ujungnya Aristoteles terjebak dalam pemahaman dualistik,meski tidak serupa dengan dualisme Plato. Pada akhirnya, teori keduanya masih belum memberikan solusi bagi persoalan kedirian manusia dalam kehidupan seharihari (Albiruni, 2950). 
Setelah masa Aristoteles, terjadi peralihan corak pemikiran filsafat Yunani menjadi filsafat Helen-Romawi terutama disebabkan oleh perluasan wilayah kerajaan Romawi pada masa Alexander Agung (356-313 SM), salah seorang murid dari Aristoteles. Dengan semakin meluasnya wilayah kerajaan Romawi, keinginan menguasai pengetahuan teoritis makin beralih kepada ilmu-ilmu khusus yang lebih berguna bagi kehidupan faktual kala itu. Kepercayaan rakyat pada agama semakin menyusut, sehingga orang makin mencari hasil praktis yang bernilai guna untuk meningkatkan kesenangan hidup sebagai akibat perbudakan dan kondisi sosial yang menekan. Ilmu yang berkembang pada masa itu adalah etika, suatu ajaran tentang martabat hidup di dunia, maupun pengetahuan khusus yang sifatnya praktis. Dalam periode ini berdirilah sekolah yang didirikan oleh Epicurus (341-117 SM), (Aune and Bruce, 1998).

Berlainan dengan Aristoteles, Epicurus tidak mempunyai perhatian terhadap penyelidikan ilmiah. Ia hanya mempergunakan pengetahuan yang diperolehnya sebagai alat membebaskan manusia dari ketakutan agama, yaitu rasa takut terhadap dewa-dewa yang ditanam dalam diri manusia oleh agama Yunani Kuno. Menurutnya, ketakutan terhadap dewa-dewa yang menjadi penghalang besar untuk memperoleh kesenangan hidup. Mengembangkan fisika praktis untuk membebaskan manusia dari kepercayaan pada dewa-dewa. Mencoba menjelaskan bahwa segala yang terjadi bersifat kausalitas-mekanis. Tidak perlu dewa-dewa diikutsertakan dalam peredaran alam. Semenjak berakhirnya periode Aristoteles, dapat dikatakan filsafat Yunani kehilangan masa keemasannya dan jatuh pada penelaahan yang sifatnya spasial dan kehilangan sifat penelitian yang mendasar, sebagaimana yang dirintis oleh Epikuros. Refleksi masa lalu ini mengawali untuk memberi perbandingan perspektif menurut filsafat dan Islam tentang menjadi manusia yang selalu direnungkan oleh dirinya sendiri hingga saat ini (Blackman, 1952).

\subsection{Filsafat Zaman Yunani}

Secara etimologis kata filsafat dari kata Yunani filosofia, yg berasal dari kata kerja filosofi yang berarti mencintai kebijaksanaan. Kata filsafat juga berasal dari kata Yunani philosophia yg berasal dari kata kerja philein yg berarti mencintai/philia yang berarti cinta, dan Sophia yang berarti kearifan. 
Berdasarkan kata tersebut lahirlah kata Inggris philosophy yang biasa diterjemahkan "cinta kearifan".

Berbicara tentang kelahiran dan perkembangan filsafat pada awal kelahirannya tidak dapat dipisahkan dengan perkembangan (ilmu) pengetahuan yang munculnya pada masa peradaban kuno (masa yunani). Dalam sejarah filsafat biasanay filsafat yunani dimajukan sebagai pangkal sejarah filsafat barat, karena dunia barat (Eropa Barat) dalam alam pikirannya berpangkal kepada pemikiran yunani. Pada masa itu ada keterangan-keterangan tentang terjadinya alam semesta serta dengan penghuninya, tetapi keterangan ini berdasarkan kepercayaan. Para ahli pikir tidak puas tentang keterangan itu lalu mencoba mencari keterangan melalui budinya (Buren, 1993).

\subsubsection{Pemikiran pada Zaman Yunani Kuno}

Masa Yunani kuno, filsafat secara umum sangat dominan, meski harus diakui bahwa agama masih kelihatan memainkan peran. Hal ini terjadi pada tahap permulaan, yaitu pada masa Thales (640-545 SM), yang menyatakan bahwa esensi segala sesuatu adalah air, belum murni bersifat rasional. Argumen Thales masih dipengaruhi kepercayaan pada mitos Yunani. Demikian juga Phitagoras (571-500 SM) belum murni rasional. Ordonya yang mengharamkan makan biji kacang menunjukkan bahwa masih dipengaruhi mitos. Jadi, dapat dikatakan bahwa agama alam bangsa Yunani masih dipengaruhi misteri yang membujuk pengikutnya, sehingga dapat disimpulkan bahwa mitos bangsa Yunani bukanlah agama yang berkualitas tinggi. Secara umum dapat dikatakan, para filosof praSocrates berusaha membebaskan diri dari belenggu mitos dan agama asalnya (Fahry, 2001).

Socrates menyumbangkan teknik kebidanan (maieutica tekhne) dalam berfilsafat. Bertolak dari pengalaman konkrit, melalui dialog seseorang diajak Socrates (sebagai sang bidan) untuk "melahirkan" pengetahuan tentang kebenaran yang dikandung dalam batin orang itu. Dengan demikian Socrates meletakkan dasar bagi pendekatan deduktif. Pemikiran Sokrates dibukukan oleh Plato, muridnya. Hidup pada masa yang sama dengan mereka yang menamakan diri sebagai "sophis" ("yang bijaksana dan berapengetahuan"), Sokrates lebih berminat pada masalah manusia dan tempatnya dalam masyarakat, dan bukan pada kekuatan-kekuatan yang ada dibalik alam raya ini (para dewa-dewi mitologi Yunani). Seperti diungkapkan oleh Cicero kemudian, Socrates "menurunkan filsafat dari langit, mengantarkannya ke kota-kota, 
memperkenalkannya ke rumah-rumah". Karena itu dia didakwa "memperkenalkan dewa-dewi baru, dan merusak kaum muda" dan dibawa ke pengadilan Kota Athena. Dengan mayoritas tipis, juri 500 orang menyatakan bersalah. Sesungguhnya dapat menyelamatkan nyawanya dengan meninggalkan Kota Athena, namun setia pada hati nuraninya memilih meminum racun cemara di hadapan banyak orang untuk mengakhiri hidupnya (Hadiwijono, 2002).

Filsafat pra-Sokrates ditandai oleh usaha mencari asal (asas) segala sesuatu. Tidakkah di balik keanekaragaman realitas di alam semesta itu hanya ada satu asas? Thales mengusulkan: air, Anaximandros: yang tak terbatas, Empedokles: api-udara-tanah-air. Herakleitos mengajar bahwa segala sesuatu mengalir ("panta rei" = selalu berubah), sedang Parmenides mengatakan bahwa kenyataan justru tak berubah. Namun tetap menjadi pertanyaan: bagaimana yang satu itu muncul dalam bentuk yang banyak, dan bagaimana yang banyak itu sebenarnya hanya satu? Pythagoras (580-500 sM) dikenal oleh sekolah yang didirikannya untuk merenungkan hal itu. Democritus (460-370 sM) dikenal oleh konsepnya tentang atom sebagai basis untuk menerangkannya. Puncak zaman Yunani dicapai pada pemikiran filsafati Socrates (470-399 sM), Plato (418-348 sM) dan Aristoteles (384-311 SM). Pada abad ke-6 SM orang Yunani mempunyai sistem kepercayaan bahwa segala sesuatunya harus diterima sebagai sesuatu yang bersumber pada mitos atau dongeng-dongeng, yang artinya suatu kebenaran lewat akal pikir (logis) tidak berlaku, yang berlaku hanya suatu kebenaran yang bersumber dari mitos (dongeng-dongeng) (Hardiman, 2003).

\subsubsection{Filsafat Masa Setelah Abad 6 SM}

Setelah abad ke-6 SM muncul sejumlah ahli pikir yang menentang adanya mitos. Mereka menginginkan adanya pertanyaan tentang misteri alam semesta ini, jawabannya dapat diterima akal (rasional). Keadaan yang demikian ini sebagai suatu demitologi, artinya suatu kebangkitan pemikiran untuk menggunakan akal pikir dan meninggalkan hal-hal yang sifatnya mitologi.upaya para ahli pikir untuk mengarahkan kepada suatu kebebasan berfikir, ini kemudian banyak orang mencoba membuat suatu konsep yang dilandasi kekuatan akal pikir secara murni, maka timbullah peristiwa ajaib The Greek Miracle yang artinya dapat dijadikan sebagai landasan peradaban dunia. 
Pelaku filsafat adalah akal dan musuhnya adalah hati. Pertentangan antara akal dan hati itulah pada dasarnya isi sejarah filsafat. Di dalam sejarah filsafat kelihatan akal pernah menang, pernah kalah, hati pernah berjaya, juga pernah kalah, pernah juga kedua-duanya sama-sama menang. Di antara keduanya, dalam sejarah, telah terjadi pergumulan berebut dominasi dalam mengendalikan kehidupan manusia.

Akal didefinisikan sebagai bagian pikir yang logis yang bertempat di kepala, sedangkan hati adalah rasa yang kira-kira bertempat di dalam dada. akal itulah yang menghasilkan pengetahuan logis yang disebut filsafat, sedangkan hati pada dasarnya menghasilkan pengetahuan supralogis yang disebut pengetahuan mistik, iman termasuk disini. Ciri umum filsafat yunani adalah rasionalisme yang dimana mencapai puncaknya pada orang-orang sofis (Huujbers and Theo, 1987).

Sejarah filsafat biasanay filsafat yunani dimajukan sebagai pangkal sejarah filsafat barat, karena dunia barat (Eropa Barat) dalam alam pikirannya berpangkal kepada pemikiran yunani. Pada masa itu ada keterangan-keterangan tentang terjadinya alam semesta serta dengan penghuninya akan tetapi keterangan ini berdasarkan kepercayaan. Ahli-ahli pikir tidak puas dengan keterangan itu lalu mencoba mencari keterangan melalui budinya. Mereka menanyakan dan mencari jawabannya apakah sebetulnya alam itu. Apakah intisarinya? Mungkin yang beraneka warna yang ada dalam alam ini dapat dipulangkan kepada yang satu. Mereka mencari inti alam, dengan istilah mereka: mereka mencari arche alam (arche dalam bahasa yunani yang berarti mula, asal) (Iqbal, 2976).

Terdapat tiga faktor yang menjadikan filsafat yunani ini lahir, yaitu:

1. Bangsa Yunani yang kaya mengenai mitos (dongeng), dan mitos dianggap sebagai awal dari upaya orang untuk mengetahui atau mengerti. Mitos-mitos tersebut kemudian disusun secara sistematis yang untuk sementara kelihatan rasional sehingga muncul mitos selektif dan rasional, seperti syair karya Homerus, Orpheus dan lain-lain.

2. Karya sastra yunani yang dapat dianggap sebagai pendorong kelahiran filsafat yunani, karya Homerus mempunyai kedudukan yang sangat penting untuk pedoman hidup orang-orang yunani yang didalamnya mengandung nilai-nilai edukatif.

3. Pengaruh ilmu-ilmu pengetahuan yang berasal dari Babylonia (Mesir) di lembah sungai Nil, kemudian berkat kemampuan dan kecakapannya ilmu- 
ilmu tersebut dikembangkan sehingga mereka mempelajarinya tidak didasarkan pada aspek praktis saja, tetapi juga aspek teoritis kreatif.

Ketiga faktor tersebut, kedudukan mitos digeser oleh logos (akal), sehingga setelah pergeseran tersebut filsafat lahir.

Periode Yunani kuno ini lazim disebut periode filsafat alam. Dikatakan demikian, karena pada periode ini ditandai dengan munculnya para ahli pikir alam, dimana arah dan perhatian pemikirannya kepada hal yang diamati sekitarnya.mereka membuat pertanyaan-pertanyaan tentang gejala alam yang bersifat filsafati (berdasarkan akal pikir) dan tidak berdasarkan pada mitos. Mereka mencari asas yang pertama dari alam semesta (arche) yang sifatnya mutlak, yang berada di belakang segala sesuatu yang serba berubah (Ja'far, 2014).

Para pemikir filsafat yunani yang pertama berasal dari Miletos, sebuah kota perantauan Yunani yang terletak di pesisir Asia Kecil. Mereka kagum terhadap alam yang oleh nuansa dan ritual dan berusaha mencari jawaban atas apa yang ada di belakang semua materi itu.

\subsubsection{Perkembangan Filsafat}

Masa Yunani Kuno. Pada tahap awal kelahirannya filsafat menampakkan diri sebagai suatu bentuk mitologi, serta dongeng-dongeng yang dipercayai oleh Bangsa Yunani, baru sesudah Thales (614-548 S.M) mengemukakan pertanyaan aneh pada waktu itu, filsafat berubah menjadi suatu bentuk pemikiran rasional (logos). Pertanyaan Thales yang menggambarkan rasa keingintahuan bukanlah pertanyaan biasa seperti apa rasa kopi?, atau pada tahun keberapa tanaman kopi berbuah?, pertanyaan Thales yang merupakan pertanyaan filsafat, karena mempunyai bobot yang dalam sesuatu yang ultimate (bermakna dalam) yang mempertanyakan tentang Apa sebenarnya bahan alam semesta ini (What is the nature of the world stuff?), atas pertanyaan ini indra tidak bisa menjawabnya, sains juga terdiam, namun Filsuf berusaha menjawabnya. Thales menjawab Air (Water is the basic principle of the universe), dalam pandangan Thales air merupakan prinsip dasar alam semesta, karena air dapat berubah menjadi berbagai wujud (Iqbal, 1981)

Kemudian silih berganti Filsuf memberikan jawaban terhadap bahan dasar (Arche) dari semesta raya ini dengan argumentasinya masing-masing. Anaximandros (610-540 S.M) mengatakan Arche is to Apeiron, Apeiron adalah 
sesuatu yang paling awal dan abadi, Pythagoras (580-500 S.M) menyatakan bahwa hakikat alam semesta adalah bilangan, Demokritos (460-370 S.M) berpendapat hakikat alam semesta adalah Atom, Anaximenes (585-518 S.M) menyatakan udara, dan Herakleitos (544-484 S.M) menjawab asal hakekat alam semesta adalah api, dia berpendapat bahwa di dunia ini tak ada yang tetap, semuanya mengalir. Variasi jawaban yang dikemukakan para filsuf mengenai dinamika pemikiran yang mencoba mendobrak dominasi mitologi, mereka mulai secara intens memikirkan tentang Alam/Dunia, sehingga sering dijuluki sebagai Philosopher atau ahli tentang Filsafat Alam (Natural Philosopher), yang dalam perkembangan selanjutnya melahirkan Ilmu-ilmu kealaman (Kaufimann, 1975).

Pada perkembangan selanjutnya, di samping pemikiran tentang Alam, para ahli pikir Yunani pun banyak yang berupaya memikirkan tentang hidup kita (manusia) di Dunia. Dari titik tolak ini lahirlah Filsafat moral (atau filsafat sosial) yang pada tahapan berikutnya mendorong lahirnya Ilmu-ilmu sosial. Diantara filsuf terkenal yang banyak mencurahkan perhatiannya pada kehidupan manusia adalah Socrates (470-399 S.M), dia sangat menentang ajaran kaum Sofis. Adanya ke cenderung mempermainkan kebenaran, Socrates berusaha meyakinkan bahwa kebenaran dan kebaikan sebagai nilai-nilai yang objektif yang harus diterima dan dijunjung tinggi oleh semua orang. Dia mengajukan pertanyaan pada siapa saja yang ditemui di jalan untuk membukakan batin warga Athena kepada kebenaran (yang benar) dan kebaikan (yang baik). Dari prilakunya ini pemerintah Athena menganggap Socrates sebagai penghasut, dan akhirnya dia dihukum mati dengan jalan meminum racun (Knasas, 2003).

Sesudah Socrates meninggal, filsafat Yunani terus berkembang dengan Tokohnya Plato (417-347 S.M), salah seorang murid Socrates. Diantara pemikiran Plato yang penting adalah berkaitan dengan pembagian relaitas ke dalam dua bagian yaitu realitas/dunia yang hanya terbuka bagi rasio, dan dunia yang terbuka bagi panca indera, dunia pertama terdiri dari idea-idea, dan dunia ke dua adalah dunia jasmani (pancaindra), dunia ide sifatnya sempurna dan tetap, sedangkan dunia jasmani selalu berubah. Dengan pendapatnya tersebut, menurut Kees Berten (1976), Plato berhasil mendamaikan pendapatnya Herakleitos dengan pendapatnya Permenides, menurut Herakleitos segala sesuatu selalu berubah, ini benar kata Plato, tapi hanya bagi dunia Jasmani (Pancaindra), sementara menurut Permenides segala sesuatu sama sekali sempurna dan tidak dapat berubah, ini juga benar kata Plato, tapi hanya berlaku pada dunia idea saja. 
Sejarah Filsafat Yunani, terdapat seorang filsuf yang sangat legendaris yaitu Aristoteles (384-311 S.M), seorang yang pernah belajar di Akademia Plato di Athena. Setelah Plato meninggal Aristoteles menjadi guru pribadinya Alexander Agung selama dua tahun, sesudah itu dia kembali lagi ke Athena dan mendirikan Lykeion, dia sangat mengagumi pemikiran-pemikiran Plato meskipun dalam filsafat, Aristoteles mengambil jalan yang berbeda (Aristoteles pernah mengatakan-ada juga yang berpendapat bahwa ini bukan ucapan Aristoteles- Amicus Plato, magis amica veritas - Plato memang sahabatku, tapi kebenaran lebih akrab bagiku - ungkapan ini terkadang diterjemahkan bebas menjadi "Saya mencintai Plato, tapi saya lebih mencintai kebenaran"), (Langiulli, 1971)

Aristoteles mengkritik tajam pendapat Plato tentang idea-idea, menurut Dia yang umum dan tetap bukanlah dalam dunia idea akan tetapi dalam benda-benda jasmani itu sendiri, untuk itu Aristoteles mengemukakan teori Hilemorfisme $($ Hyle $=$ Materi, Morphe $=$ bentuk), menurut teori ini, setiap benda jasmani memiliki dua hal yaitu bentuk dan materi, sebagai contoh, sebuah patung pasti memiliki dua hal yaitu materi atau bahan baku patung misalnya kayu atau batu, dan bentuk misalnya bentuk kuda atau bentuk manusia, keduanya tidak mungkin lepas satu sama lain, contoh tersebut hanyalah untuk memudahkan pemahaman, sebab dalam pandangan Aristoteles materi dan bentuk itu merupakan prinsip-prinsip metafisika untuk memperkukuh dimungkinkannya Ilmu pengetahuan atas dasar bentuk dalam setiap benda konkrit. Teori hilemorfisme juga menjadi dasar bagi pandangannya tentang manusia, manusia terdiri dari materi dan bentuk, bentuk adalah jiwa, dan karena bentuk tidak pernah lepas dari materi, maka konsekuensinya adalah bahwa apabila manusia mati, jiwanya (bentuk) juga d hapat hancur (Leksono, 1994).

Disamping pendapat tersebut Aristoteles juga dikenal sebagai Bapak Logika yaitu suatu cara berpikir yang teratur menurut urutan yang tepat atau berdasarkan hubungan sebab akibat. Dia adalah yang pertama kali membentangkan cara berpikir teratur dalam suatu sistem, yang intisarinya adalah Silogisme (masalah ini akan diuraikan khusus dalam topik Logika) yaitu menarik kesimpulan dari kenyataan umum atas hal yang khusus (Luijpen, 1960).

Abad Pertengahan. Semenjak meninggalnya Aristoteles, filsafat terus berkembang dan mendapat kedudukan yang tetap penting dalam kehidupan pemikiran manusia meskipun dengan corak dan titik tekan yang berbeda. Periode sejak meninggalnya Aristoteles (atau sesudah meninggalnya Alexander 
Agung (313 S.M) sampai menjelang lahirnya Agama Kristen oleh Droysen (Ahmad Tafsir. 1991) disebut periode Hellenistik (Hellenisme adalah istilah yang menunjukan kebudayaan gabungan antara budaya Yunani dan Asia Kecil, Syiria, Mesopotamia, dan Mesir Kuno). Dalam masa ini Filsafat ditandai antara lain dengan perhatian pada hal yang lebih aplikatif, serta kurang memperhatikan Metafisika, dengan semangat yang Eklektik (mensintesiskan pendapat yang berlawanan) dan bercorak Mistik (Marcel, 1949).

Dunia Islam (Umat Islam) lahir filsuf-filsuf terkenal seperti Al Kindi (801-865 M), Al Farabi (870-950 M), Ibnu Sina (980-1037 M), Al Ghazali (1058-1111 M), dan Ibnu Rusyd (1116-1198), sementara itu di dunia Kristen lahir Filsuffilsuf antara lain seperti Peter Abaelardus (1079-1180), Albertus Magnus (1103$1180 \mathrm{M}$ ), dan Thomas Aquinas (1115-1174). Mereka ini disamping sebagai Filsuf juga orang-orang yang mendalami ajaran agamanya masing-masing, sehingga corak pemikirannya mengacu pada upaya mempertahankan keyakinan agama dengan jalan filosofis, meskipun dalam banyak hal terkadang ajaran Agama dijadikan Hakim untuk memvonis benar tidaknya suatu hasil pemikiran Filsafat (Pemikiran Rasional).

Masa Modern. Para filsuf zaman modern menegaskan bahwa pengetahuan tidak berasal dari kitab suci atau ajaran agama, tidak juga dari para penguasa, tetapi dari diri manusia sendiri. Namun tentang aspek mana yang berperan ada bedah pendapat. Aliran rasionalisme beranggapan bahwa sumber pengetahuan adalah rasio: kebenaran pasti berasal dari rasio (akal). Aliran empirisme, sebaliknya, meyakini pengalamanlah sumber pengetahuan itu, baik yang batin, maupun yang inderawi. Lalu muncul aliran kritisisme, yang mencoba memadukan kedua pendapat berbeda itu (Anonim, 1950).

Aliran rasionalisme dipelopori oleh Rene Descartes (1596-1650 M). Dalam buku Discourse de la Methode tahun 1637, menegaskan perlunya ada metode yang jitu sebagai dasar kokoh bagi semua pengetahuan, yaitu dengan menyangsikan segalanya, secara metodis. Kalau suatu kebenaran tahan terhadap ujian kesangsian yang radikal ini, maka kebenaran itu 100\% pasti dan menjadi landasan bagi seluruh pengetahuan.

Tetapi dalam rangka kesangsian yang Metodis ini ternyata hanya ada satu hal yang tidak dapat diragukan, yaitu "saya ragu-ragu". Ini bukan khayalan, tetapi kenyataan, bahwa "aku ragu-ragu". Jika aku menyangsikan sesuatu, aku menyedari bahwa aku menyangsikan adanya. Kesangsian itu langsung menyatakan adanya aku. Itulah "cogito ergo sum", aku berpikir menyedari) maka aku ada. Itulah kebenaran yang tidak dapat disangkal lagi. Mengapa 
kebenaran itu pasti? Sebab aku mengerti itu dengan "jelas, dan terpilah-pilah" "clearly and distinctly", "Clara Et distincta". Artinya jelas dan terpilah-pilah itulah yang harus diterima sebagai benar. Dan itu menjadi norma Descartes dalam menentukan kebenaran.

Descartes menerima 3 realitas atau substansi bawaan, yang sudah ada sejak kita lahir, yaitu (1) realitas pikiran (res cogitan), (1) realitas perluasan (res extensa, "extention") atau materi, dan (3) Tuhan (sebagai Wujud yang seluruhnya sempurna, penyebab sempurna dari kedua realitas itu). Pikiran sesungguhnya adalah kesadaran, tidak mengambil ruang dan tak dapat dibagi-bagi menjadi bagian yang lebih kecil. Materi adalah keluasan, mengambil tempat dan dapat dibagi-bagi, dan tak memiliki kesadaran. Kedua substansi berasal dari Tuhan, sebab hanya Tuhan sajalah yang ada tanpa tergantung pada apapun juga. Descartes adalah seorang dualis, menerapkan pembagian tegas antara realitas pikiran dan realitas yang meluas. Manusia memiliki keduanya, sedang binatang hanya memiliki realitas keluasan: manusia memiliki badan sebagaimana binatang, dan memiliki pikiran sebagaimana malaikat. Binatang adalah mesin otomatis, bekerja mekanistik, sedang manusia adalah mesin otomatis yang sempurna, karena dari pikirannya yang memiliki kecerdasan. (Mesin otomatis jaman sekarang adalah komputer yang tampak seperti memiliki kecerdasan buatan) (Misiak, 2005).

Descartes adalah pelopor kaum rasionalis, yaitu mereka yang percaya bahwa dasar semua pengetahuan ada dalam pikiran.Aliran empirisme nyata dalam pemikiran David Hume (1711-1776), yang memilih pengalaman sebagai sumber utama pengetahuan. Pengalaman itu dapat yang bersifat lahiriyah (yang menyangkut dunia), maupun yang batiniah (yang menyangkut pribadi manusia). Oleh karena itu pengenalan inderawi merupakan bentuk pengenalan yang paling jelas dan sempurna. Dua hal dicermati oleh Hume, yaitu substansi dan kausalitas. Hume tidak menerima substansi, sebab yang dialami hanya kesan-kesan saja tentang beberapa ciri yang selalu ada bersama-sama. Dari kesan muncul gagasan. Kesan adalah hasil penginderaan langsung, sedang gagasan adalah ingatan mengenai kesan-kesan seperti itu. Misal kualami kesan: putih, licin, ringan, tipis. Atas dasar pengalaman itu tidak dapat disimpulkan, bahwa ada substansi tetap yang misalnya disebut kertas, yang memiliki ciri-ciri tadi. Bahwa di dunia ada realitas kertas, diterima oleh Hume. Namun dari kesan itu mengapa muncul gagasan kertas, dan bukan yang lainnya? Bagi Hume, "aku" tidak lain hanyalah "a bundle or collection of perceptions (kesadaran tertentu)"(Muthahari, 2002). 
Kausalitas. Jika gejala tertentu diikuti oleh gejala lainnya, misal batu yang disinari matahari menjadi panas, kesimpulan itu tidak berdasarkan pengalaman. Pengalaman hanya memberi kita urutan gejala, tetapi tidak memperlihatkan kepada kita urutan sebab-akibat. Yang disebut kepastian hanya mengungkapkan harapan kita saja dan tidak boleh dimengerti lebih dari "probable" (berpeluang). Maka Hume menolak kausalitas, sebab harapan bahwa sesuatu mengikuti yang lain tidak melekat pada hal-hal itu sendiri, namun hanya dalam gagasan kita. Hukum alam adalah hukum alam. Jika kita bicara tentang "hukum alam" atau "sebab-akibat", sebenarnya kita membicarakan apa yang kita harapkan, yang merupakan gagasan kita saja, yang lebih didikte oleh kebiasaan atau perasaan kita saja. Hume merupakan pelopor para empiris, yang percaya bahwa seluruh pengetahuan tentang dunia berasal dari indera. Menurut Hume ada batasanbatasan yang tegas tentang bagaimana kesimpulan dapat diambil melalui persepsi indera kita (Nars, 1997).

Kritisisme Immanuel Kant (1714-1804) mencoba mengembangkan suatu sintesis atas dua pendekatan yang bertentangan ini. Kant berpendapat bahwa masing-masing pendekatan benar separuh, dan salah separuh. Benarlah bahwa pengetahuan kita tentang dunia berasal dari indera kita, namun dalam akal kita ada faktor-faktor yang menentukan bagaimana kita memandang dunia sekitar kita. Ada kondisi-kondisi tertentu dalam manusia yang ikut menentukan konsepsi manusia tentang dunia. Kant setuju dengan Hume bahwa kita tidak mengetahui secara pasti seperti apa dunia "itu sendiri” (“das Ding sich"), namun hanya dunia itu seperti tampak "bagiku", atau "bagi semua orang". Namun, menurut Kant, ada dua unsur yang memberi sumbangan kepada pengetahuan manusia tentang dunia. Yang pertama adalah kondisi-kondisi lahiriyah ruang dan waktu yang tidak dapat kita ketahui sebelum kita menangkapnya dengan indera kita. Ruang dan waktu adalah cara pandang dan bukan atribut dari dunia fisik. Itu materi pengetahuan. Yang kedua adalah kondisi-kondisi batiniah dalam manusia mengenai proses-proses yang tunduk kepada hukum kausalitas yang tak terpatahkan. Ini bentuk pengetahuan (Natanson, 1973)

Kant membuat kritik atas seluruh pemikiran filsafat, membuat suatu sintesis, dan meletakkan dasar bagi aneka aliran filsafat masa kini. Filsafat zaman modern berfokus pada manusia, bukan kosmos (seperti pada zaman kuno), atau Tuhan (pada abad pertengahan). Dalam zaman modern pada periode yang disebut Renaissance (kelahiran kembali). Kebudayaan klasik warisan YunaniRomawi dicermati dan dihidupkan kembali; seni dan filsafat mencari inspirasi. Filsuf penting adalah N Machiavelli (1469-1517), Thomas Hobbes (15881679), Thomas More (1478-1535) dan Francis Bacon (1561-1616). Periode 
kedua adalah zaman Barok, yang menekankan akal budi. Sistem filsafatnya juga menggunakan menggunakan matematika. Para filsuf periode ini adalah Rene Descartes, Barukh de Spinoza (1631-1677) dan Gottfried Wilhelm Leibniz (1646-1710). Periode ketiga ditandai dengan fajar budi (enlightenment atau Aufklarung). Para filsuf kategori ini adalah John Locke (1631-1704), G Berkeley (1684-1753), David Hume (1711-1776). Dalam kategori ini juga dimasukkan Jean-Jacques Rousseau (1711-1778) dan Immanuel Kant. Masa kini (1800-sekarang) (Partenie, 2003).

\subsubsection{Filsafat Abad 18 Masehi}

Filsafat masa kini merupakan aneka bentuk reaksi langsung atau tak langsung atas pemikiran Georg Wilhelm Friedrich Hegel (1770-1831). Hegel ingin menerangkan alam semesta dan gerak-geriknya berdasarkan suatu prinsip. Menurut Hegel semua yang ada dan semua kejadian merupakan pelaksanaanyang-sedang-berjalan dari Yang Mutlak dan bersifat rohani. Namun celakanya, Yang Mutlak itu tidak mutlak jika masih harus dilaksanakan, sebab jika betulbetul mutlak, tentunya maha sempurna, dan jika maha sempurna tidak menjadi. Oleh sebab itu pemikiran Hegel langsung ditentang oleh aliran pemikiran materialisme yang mengajarkan bahwa yang sedang-menjadi itu, yang sering sedang-menjadi-lebih-sempurna bukanlah ide (Mutlak), namun adalah materi belaka. Maksudnya, yang sesungguhnya ada adalah materi (alam benda); materi adalah titik pangkal segala sesuatu dan segala sesuatu yang mengatasi alam benda harus dikesampingkan. Maka seluruh realitas hanya dapat dibuat jelas dalam alur pemikiran ini. Itulah paham yang dicetuskan oleh Ludwig Andreas Feuerbach (1804-1871). Sayangnya, materi itu sendiri tidak bisa menjadi mutlak, karena pastilah ada yang-ada-di-luar-materi yang "mengendalikan" proses dalam materi itu untuk materi bisa menjadi-lebih-sempurna-darisebelumnya (Preus, 2003).

Kesalahan Hegel adalah tidak menerima bahwa yang mutlak itu berdiri sendiri dan ada-diatas-segalanya, dalam arti tidak dalam satu realitas dengan segala yang sedang-menjadi tersebut. Dengan mengatakan Yang Mutlak itu menjadi, Hegel pada dasarnya meniadakan kemutlakan. Cara yang sama dengan mengatakan bahwa yang mutlak itu materi, maka materialisme pun jatuh dalam kubangan yang sama ((Rahman, 1995).

Sesuai hal di atas dapat dipahami bahwa munculnya sejumlah aliran-aliran penting dewasa ini: Positivisme menyatakan bahwa pemikiran setiap manusia, 
tiap ilmu dan suku bangsa melalui 3 tahap, yaitu teologis, metafisis dan positif ilmiah. Manusia muda atau suku-suku primitif pada tahap teologis" dibutuhkan figur dewa-dewa untuk "menerangkan" kenyataan. Meningkat remaja dan mulai dewasa dipakai prinsip-prinsip abstrak dan metafisis. Pada tahap dewasa dan matang digunakan metode-metode positif dan ilmiah. Aliran positivisme dianut oleh Auguste Comte (1798-1857), John Stuart Mill (1806-1873) dan H Spencer (1810-1903), dan dikembangkan menjadi neo-positivisme oleh kelompok filsuf lingkaran Wina (Rapar, 1996).

Marxisme (nama mengikuti tokoh utama Karl Marx, 1818-1883) mengajarkan bahwa kenyataan hanya terdiri atas materi belaka, yang berkembang dalam proses dialektis (dalam ritme tesis-antitesis-sintesis). Marx adalah pengikut setia Feuerbach (sekurangnya pada tahap awal). Feuerbach berpendapat Tuhan hanyalah proyeksi manusia tentang dirinya sendiri dan agama hanyalah sarana manusia memproyeksikan cita-cita (belum terwujud!) manusia tentang dirinya sendiri. Menurut Feuerbach, yang ada bukan Tuhan yang maha adil, namun yang ada hanyalah manusia yang ingin menjadi adil. Dari sini dapat dipahami mengapa Marx berkata, bahwa "agama adalah candu bagi rakyat", karena agama hanya membawa manusia masuk dalam "syurga fantasi", suatu pelarian dari kenyataan hidup yang umumnya pahit. Selanjutnya Marx menegaskan bahwa filsafat hanya memberi interpretasi atas perkembangan masyarakat dan sejarah. Yang justru dibutuhkan adalah aksi untuk mengarahkan perubahan dan untuk itu harus dikembangkan hukum-hukum objektif mengenai perkembangan masyarakat (Sartre, 1992).

Pandangan Soekarno mengklaim telah mencetuskan marhaenisme sebagai marxisme diterapkan dalam situasi dan kondisi Indonesia. Kualifikasi "penerapan dalam situasi dan kondisi Indonesia" (apapun itu) pastilah tidak membuat faham marhaenisme sebagai suatu aliran filsafat dan pastilah tidak harus sama dengan paham marxisme sebagai diterapkan di dalam lingkungan masyarakat lain.]

Ditangan Friedrich Engels (1810-1895), dan oleh Lenin, Stalin dan Mao Tse Tung, aliran filsafat Marxisme ini menjadi gerakan komunisme, yaitu suatu ideologi politik praktis Partai Komunis di negara mana saja untuk merubah dunia. Sangat nyata bahwa dimana saja Partai Komunis itu menjalankan praktek-praktek yang nyatanya mengingkari hak-hak asasi manusia, dan karena itu tidak berperikemanusiaan (Schmid, 2000)

Eksistensialisme merupakan himpunan aneka pemikiran yang memiliki inti yang sama, yaitu keyakinan, bahwa filsafat harus berpangkal pada adanya 
(eksistensi) manusia konkrit, dan bukan pada hakekat (esensi) manusia-padaumumnya. Manusia-pada-umumnya tidak ada, yang ada hanya manusia ini, manusia itu. Esensi manusia ditentukan oleh eksistensinya. Tokoh aliran ini J P Sartre (1905-1980), Kierkegaard (1813-1855), Friedrich Nietzsche (18441900), Karl Jaspers (1883-1969), Martin Heidegger (1889-1976), Gabriel Marcel (1889-1973).

Fenomenologi merupakan aliran (tokoh penting: Edmund Husserl, 1859-1938) yang ingin mendekati realitas tidak melalui argumen-argumen, konsep-konsep, atau teori umum. "Zuruck zu den sachen selbst" - kembali kepada bendabenda itu sendiri, merupakan inti dari pendekatan yang dipakai untuk mendeskripsikan realitas menurut apa adanya. Setiap objek memiliki hakekat, dan hakekat itu berbicara kepada kita jika kita membuka diri kepada gejalagejala yang kita terima. Kalau kita "mengambil jarak" dari objek itu, melepaskan objek itu dari pengaruh pandangan-pandangan lain, dan gejalagejala itu kita cermati, maka objek itu "berbicara" sendiri mengenai hakekatnya, dan kita memahaminya berkat intuisi dalam diri kita. Fenomenologi banyak diterapkan dalam epistemologi, psikologi, antropologi, dan studi-studi keagamaan (misalnya kajian atas kitab suci) (Schumacher, 1988).

Pragmatisme tidak menanyakan "apakah itu?" melainkan "apakah gunanya itu?" atau "untuk apakah itu?". Yang dipersoalkan bukan "benar atau salah", karena ide menjadi benar oleh tindakan tertentu. Tokoh aliran ini: John Dewey (1859-1914).

Neo-kantianisme dan neo-thomisme merupakan aliran-aliran yang merupakan kelahiran kembali dari aliran yang lama, oleh dialog dengan aliran lain. Disamping itu masih ada aliran filsafat analitik yang menyibukkan diri dengan analisis bahasa dan analisis atas konsep-konsep. Dalam berfilsafat, jangan katakan jika hal itu tidak dapat dikatakan. "Batas-batas bahasaku adalah batasbatas duniaku". Soal-soal falsafi seyogyanya dipecahkan melalui analisis atas bahasa, untuk mendapatkan atau tidak mendapatkan makna dibalik bahasa yang digunakan. Hanya dalam ilmu pengetahuan alam pernyataan memiliki makna, karena pernyataan itu bersifat faktual. Tokoh pencetus: Ludwig Wittgenstein (1889-1951) (Sharif, 1963).

Akhirnya sejak 1960 berkembang strukturalisme yang menyelidiki pola-pola dasar yang tetap yang terdapat dalam bahasa-bahasa, agama-agama, sistemsistem dan karya-karya kesusasteraan. 


\subsubsection{Pendapat Para Ahli tentang Filsafat}

1. Thales (615-545 SM)

Nama Thales muncul atas penuturan sejarawan Herodotus pada abad ke-5 SM. Thales sebagai salah satu dari tujuh orang yang bijaksana (Seven Wise Men of Greece). Aristoteles memberikan gelar The Father of Filosophy.juga menjadi penasihat teknis ke-11 Kota Lonia. Salah satu jasanya yang besar adalah meramal gerhana matahari pada tahun $585 \mathrm{SM}$.

Thales berpendapat bahwa dasar pertama atau intisari alam ialah air. Thales mengembangkan filsafat alam kosmologi yang mempertanyakan asal mula, sifat dasar dan struktur komposisi dari alam semesta. Sebagai ilmuwan pada masa itu Thales mempelajari magnetisme dan listrik yang merupakan pokok soal fisika. Juga mengembangkan astronomi dan matematika dengan mengemukakan pendapat, bahwa bulan bersinar karena memantulkan cahaya matahari. Dengan demikian, Thales merupakan ahli matematika yang pertama dan juga The Father of Deductive reasoning (bapak penalaran deduktif).

Menurut sejarah Matematika, Thales dianggap sebagai pelopor geometri abstrak yang didasarkan kepada petunjuk pengukur banjir, yang implementasinya dengan membuktikan dalil-dalil geometri yang salah satunya: bahwa kedua sudut alas dari suatu segitiga sama kaki adalah sama besarnya. Walaupun pandangan -pandangan Thales banyak yang kurang jelas, akan tetapi pendapatnya merupakan percobaan pertama yang masih sangat sederhana dengan menggunakan rasio (akal pikiran).

2. Anaximandros (640-546 SM)

Anaximandros adalah orang pertama yang mengarang suatu traktat dalam kesusastraan Yunani dan berjasa dalam bidang astronomi, geografi, sehingga Anaximandros sebagai orang pertama yang membuat peta bumi.ia berhasil memimpin sekelompok orang yang membuat kota baru di Apollonia, Yuanani.

Anaximandros mengatakan bahwa dasar pertama itu ialah zat yang tak tertentu sifat-sifatnya, yang dinamai to apeiron.adapun anaximenes (590518) mengatakan bahwa intisari alam atau dasarnya pertama adalah udara.karena udaralah ynag meliputi seluruh alam serta udara pulalah yang menjadikan dasar hidup bagi manusia yang mat diperlukan oleh nafasnya. 
Anaximander mencoba menjelaskan bahwa substansi pertama itu bersifat kekal dan ada dengan sendirinya (Mayer, 1950:19).anaximander mengatakan itu udara. Udara merupakan segala sumber kehidupan, demikian alasannya (Solomon, 1973).

3. Pythagoras ( $\pm 571-497 \mathrm{SM})$

Mengenai riwayat hidup Pythagoras dilahirkan di pulau Samos, Ionia.tanggal dan tahunnya tidak diketahui pasti. Pythagoras juga tidak meninggalkan tulisan-tulisan sehingga apa yang perlu diketahui Pythagoras diperlukan kesaksian-kesaksian. Menurut Aristoxenos seorang murid Aristoteles, Pythagoras pindah ke Kota Kroton, Italia Selatan karena tidak setuju dengan pemerintahan Polykrates yang bersifat tirani. Di kota ini, Pythagoras mendirikan sekolah agama, selama 10 tahun di kraton, kemudian pindah ke Metapontum dan meninggal di kota ini.

Pemikirannya, substansi dari semua benda adalah bilangan dan segala gejala alam merupakan pengungkapan inderawi dari perbandingan-perbandingan matematis. Bilangan merupakan intisari dasar pokok dari sifat-sifat benda (Number rules the universe = bilangan memerintah jagat raya). Pemikirannya tentang bilangan, mengemukakan bahwa setiap bilangan dasar dari 1 sampai 10 mempunyai kekuatan dan arti sendiri-sendiri. Satu adalah asal mula segala sesuatu sepuluh, dan sepuluh adalah bilangan sempurna. Bilangan gasal (ganjil) lebih sempurna daripada bilangan genap dan identik dengan finite (terbatas). Salah seorang penganut Pythagoras mengatakan bahwa tuhan Adalah bilangan tujuh, jiwa itu bilangan enam, badan itu bilangan empat (Vahid, 1973).

Pythagoras juga ada sedikit memfilsafatkan manusia dengan mengemukakan pendapat bahwa pada manusia adalah sesuatu yang bukan jasmani dan yang tak dapat mati, yang masih terus ada, jika manusia sudah tak ada. Manusia menurut Pythagoras mempunyai jiwa dan jiwa itu sekarang terhukum dan berkurung dalam badan. Maka dari itu, manusia harus membershkan diri untuk melepaskan dirinya dari kurungan dan dengan demikian dapatlah dimasuki ke dalam kebahagiaan.

Pythagoras yang mengatakan pertama kali bahwa alam semesta itu merupakan satu keseluruhan yang teratur, sesuatu yang harmonis seperti dalam musik. Pythagoras juga dikenal sebagai ahli ilmu pasti dan juga ahli musik. Dia berpendapat bahwa keharmonisan dapat tercapai dengan menggabungkan hal-hal yang berlawanan, seperti: 
- Terbatas - tak terbatas

- Ganjil-genap

- Satu-banyak

- Laki-laki-perempuan

- Diam-gerak

- Dan lain-lain

Menurut Pythagoras kearifan yang sesungguhnya hanya dimiliki oleh Tuhan saja, oleh karenanya Pythagoras tidak mau disebut sebagai seorang yang arif seperti Thales, akan tetapi menyebut dirinya philosophos yaitu pencipta kearifan. Kemudian istilah istilah yang digunakan menjadi philosophia yang terjemahan harfiah adalah cinta kearifan atau kebijaksanaan sehingga sampai sekarang secara etimologis dan singkat sederhana filsafat dapat diartikan sebagai cinta kearifan atau kebijaksanaan (Love of Wisdom) (Wrren, 2004).

4. Xenophanes (570 SM)

Xenophanes lahir di Colophon, Asia Kecil. Waktu berumur 15 tahun Xenophanes mengembara ke Yunani. Xenophanes lebih tepat dikatakan sebagai penyair dari pada ahli pikir (filosof), hanya karena ia mempunyai daya nalar yang kritis yang mempelajari pemikiran-pemikiran filsafat pada saat tu. Namanya menjadi terkenal karena untuk pertama kalinya Xenophanes melontarkan anggapan bahwa adanya konflik antara pemikiran filsafat (rasional) dengan mitos. Pendapat Xenophanes yang termuat dalam kritik terhadap Homerus dan Herodotus. Xenophanes membantah adanya antropomorfisme Tuhan, yaitu Tuhan digambarkan sebagai (seakan-akan) manusia, karena manusia selalu memiliki kecenderungan berpikir dan lainlainnya. Xenophanes juga membantah bahwa Tuhan bersifat kekal dan tidak mempunyai permulaan. Xenophanes juga menolak anggapan bahwa Tuhan mempunyai jumlah yang banyak dan menekankan atas keesaan Tuhan. Kritik ini ditujukan kepada anggapan-anggapan lama yang berdasarkan pada mitologi.

5. Heraclitos (535 - $475 \mathrm{SM})$

Heraclitos lahir di Epesus, sebuah kota perantauan di Asia Kecil dan merupakan kawan dari Pythagoras dan Xenophanes, akan tetapi ia lebih tua. Heraclitos mendapat julukan si gelap karena untuk menelusuri gerak 
pemikirannya sangat sulit. Hanya dengan melihat fragmen-fragmennya. Heraclitos mempunyai kesan hati yang tinggi dan sombong, sehingga Heraclitos mudah mencela kebanyakan manusia untuk mengatakan jahat dan bodoh, juga mencela orang -orang yang terkemuka di Yunani.

Pemikiran filsafatnya terkenal dengan filsafat menjadi. Heraclitos mengemukakan bahwa segala sesuatu (yang ada itu) sedang menjadi dan selalu berubah. Sehingga ucapannya yang terkenal: Panta rhei kai uden menci yang artinya segala sesuatunya mengalir bagaikan arus sungai dan tidak satu orangpun yang dapat masuk ke sungai dua kali. Alasannya, karena air sungai yang pertama telah mengalir, berganti dengan air yang berada di belakangnya. Demikian juga dengan segala yang ada, tidak ada yang tetap, semuanya berubah. Akhirnya dikatakan bahwa hakikat dari segala sesuatu adalah menjadi, maka filsafatnya dikatakan filsafat menjadi (Ziai, 1998).

Menurut Heraclitos alam semesta ini sealu dalm keadaan berubah, sesuatu yang dingin berubah menjadi panas, yang panas berubah menjadi dingin. Itu berarti kita hendak memahami kehidupan kosmos, kita mesti menyadari bahwa kehidupan kosmos itu dinamis. Kosmos itu tidak pernah berhenti (diam). Heraclitos selalu bergerak, dan bergerak berarti berubah. Gerak itu menghasilkan perlawanan-perlawanan, sehingga sampai pada kongkulasi bahwa yang mendasar dalam alam semesta ini bukanlah baha (stuff)-nya seperti yang dipertanyakan oleh para filosof yang pertama itu, melainkan prosesnya (Warner, 1961:18). Pernyataan "semua mengalir" berarti semua berubah bukanlah pernyataan yang sederhana. Implikasi pernyataan tersebut amat hebat. Dan tu mengandung pengertian bahwa kebenaran selalu berubah, tidak tetap. Pengertian adil pada hari ini belum tentu masih benar besok. Hari ini 1 x $2=2$, namun besok dapat juga bukan dua. Pandangan ini merupakan warna dasar filsafat sofisme (Muzairi, 2009)

Menurut pendapatnya, di alam Arche terkandung sesuatu yang hidup (seperti roh) yang disebut sebagai logos (akal atau semacam wahyu). Logos inilah yang menguasai sekaligus mengendalikan keberadaan segala sesuatu. Hidup manusia selamat sesuai dengan logos.

6. Parmenides (540-475 SM)

Parmenides lahir di Kota Elea. Kota perantauan Yunani di Italia Selatan, Arena. Parmenides dilahirkan di Elea, maka penganutnya disebut kaum Elea. Kebesarannya sama dengan kebesaran Heraclitos. Parmenides yang pertama kali memikirkan tentang hakikat tentang ada (being). 
Parmenides adalah salah seorang tokoh relativisme yang penting. Dikatakan sebagai logikawan pertama dalam sejarah filsafat, bahkan dapat disebut filosof pertama dalam pengertian modern. Sistemnya secara keseluruhan disandarkan pada dedukasi logis, tidak seperti Heraclitos, misalnya, yang menggunakan metode intuisi. Ternyata Plato amat menghargai metode parmenides. Dan Plato lebih banyak mengambil dari Parmenides dibandingkan dengan dari filosof yang lain pendahulunya (Poedjawijatna, 1980).

Parmenides berpendapat bahwa hanya pengetahuan yang tetap dan umum yang mengenai yang satu sajalah (pengetahuan budi) yang dapat dipercaya. Pengetahuan budi itulah yang dapat dipercaya, kalau Parmenides benar maka sesuailah ia dengan realitas. Sebab itu yang merupakan realitas bukanlah yang berubah dan bergerak serta beralih dan bermacam-macam, melainkan yang tetap. Realitas bukanlah yang menjadi melainkan ada. Hal ini berbeda dengan pendapat Heraclitos yaitu bahwa realitas adalah gerak dan perubahan.

Buku The way of Truth Parmenides bertanya: Apa standar kebenaran dan apa ukuran realitas? Bagaimana hal itu dapat dipahami? Parmenides menjawab: ukurannya ialah logika yang konsisten. Contoh. Ada 3 cara berpikir tentang Tuhan: pertama ada, kedua tidak ada, dan ketiga ada dan tidak ada. Yang benar ialah ada (1) tidak mungkin meyakini yang tidak ada (1) sebagai ada karena yang tidak ada pastilah tidak ada. Yang (3) tidak mungkin karena tidak mungkin Tuhan itu ada dan sekaligus tidak ada. Jadi, benar-tidaknya suatu pendapat diukur dengan logika. Disinilah muncul masalah. Bentuk ekstrem pernyataan itu adalah bahwa ukuran kebenaran adalah akal manusia (Adib, 2010).

Ada (being) itu ada, yang ada tidak dapat hilang menjadi tidak ada, dan yang tidak ada tidak mungkin muncul menjadi ada, yang tidak adalah tidak ada, sehingga tidak dapat dipikirkan. Yang dapat dipikirkan adalah hanyalah yang ada saja sedangkan yang tidak ada tidak dapat dipikirkan. Jadi, yang ada (being) itu satu, umum, tetap dan tidak dapat dibagi-bagi. Karena membagi yang ada dapat menimbulkan atau melahirkan banyak ada, dan itu tidak mungkin. yang ada dijadikan dan tidak dapat musnah.yang ada di segala tempat, oleh karenanya tidak ada ruangan yang kosong, maka di luar yang ada masih ada sesuatu yang lain.

7. Zeno ( $\pm 490-430 \mathrm{SM})$ 
Zeno lahir di Elea, dan murid dari Parmenides. Sebagai murid ia dengan gigih mempertahankan ajaran gurunya dengan cara memberikan argumentasi secara baik sehingga kemudian hari ia dianggap sebagai peletak dasar dialektika.

Menurut Aristoteles, Zeno lah yang menemukan dialektika yaitu suatu argumentasi yang bertitik tolak dari suatu pengandaian atau hipotesa, dan dari hipotesis tersebut ditarik suatu kesimpulan. Dalam melawan penentangpenentangnya kesimpulan yang diajukan oleh Zeno dari hipotesa yang diberikan adalah suatu kesimpulan yang mustahil, sehingga terbukti bahwa hipotesis itu salah ((Finkelstein, 1962).

Contoh dalam mengemukakan hipotesis terhadap melawan gerak:

a. Anak panah yang dilepaskan dari busurnya sebagai hal yang tidak bergerak, karena pada setiap saat panah tersebut berhenti di suatu tempat tertentu. Kemudian dari tempat tersebut bergerak ke suatu tempat pemberhentian yang lain dan seterusnya. Benar dikatakan bahwa anak panah tersebut meleset hingga sampai pada yang dituju, artinya perjalanan anak panah tersebut sebenarnya merupakan kumpulan pemberhentian-pemberhentian anak panah.

b. Achilles si jago lari yang termasyur dalam mitologi Yunani Tidak dapat menang melawan kura0kura, karena kura-kura berangkat sebelum Achilles, sehingga Achilles Lebih dahulu harus melewati atau mencapai titik dimana dimana kura-kura berada pada saat ia berangkat. setelah Achilles berada pada suatu titik, kura-kura tersebut sudah lebih jauh lagi seterusnya sehingga jarak antara Achiles dan kura-kura selalu berkurang akan tetapi idak pernah habis.

Argumentasi Zeno ini selama 10 abad lebih tidak dapat dipecahkan orang secara logis. Baru dapat dipecahkan setelah para ahli matematika membuat pengertian limit dari seri tak terhingga.

8. Empedocles (490-435 SM)

Lahir di Akragas, Pulau Sicilia, ia sangat dipengaruhi oleh ajaran kaum Ptagorean dan aliran keagamaan refisme. Empedocles pandai dalam bidang kedokteran, penyair retorika, politik dan pemikir. Empedocles menulis karyanya dalam bentuk puisi, seperti Parmenides.

Buku tentang alam dikatakan oleh Empedocles bahwa sebenarnya tak ada menjadi dan hilang. Empedocles mengikuti Parmenides. Apapun perbedaan 
dalam seluruh keadaan itu tak lain adalah daripada campuran dan penggabungan unsur-unsur (rizomata): air. Udara. Api, dan tanah. Keempat unsur inilah yang merupakan dasar terakhir dari segala sesuatu. Proses penggabungan ini terpelihara oleh dua kekuatan yang saling bertentangan, yaitu cinta dan benci. Karena cinta maka pada mulanya keempat unsur tersebut tersusun dalam keseimbangan, Apapun bencilah yang menceraiberikan keseimabangan yang semula itu. Cinta lalu mengambil tindakan dan mengembalikan yang semula. tetapi di cerai beraikan lagi oleh benci. Pengetahuan tidak lain daripada proses pergabungan: karena bergabung dengan tanah, kita tahu akan tanah, tergabung dengan air, Kita tahu akan air (Foster, 2009).

Dengan demikian, dalam kejadian di alam semesta ini, unsur cinta dan benci selalu menyertai. Juga, proses penggabungan dan penceraian tersebut berlaku untuk melahirkan anak-anak makhluk hidup. Sedangkan manusia pun terdiri dari empat unsur (api, udara, tanah dan air) juga mengenal akan empat unsur. Hal ini karena teori pengenalan yang dikemukakan oleh Empedocles bahwa yang sama mengenal yang sama.

9. Anaxagoras $( \pm 499-10 \mathrm{SM})$

Anaxagoras dilahirkan di Kota Klazomenai, Lonia, kemudian menetap di Athena selama 30 tahun. Anaxagoras adalah ahli pikir yang pertama yang berdomisili di Athena, dimana di kemudian hari Athena inilah menjadi pusat utama perkembangan filsafat yunani sampai abad ke $1 \mathrm{SM}$.

Pemikirannya, realitas bukanlah satu, tetapi terdiri dari banyak unsur dan tidak dapat dibagi-bagi, yaitu atom. Atom ini sebagai bagian dari materi yang terkecil dari materi sehingga tidak dapat terlihat dan jumlahnya tidak terhingga. Terbentuknya dunia (kosmos), atom-atom yang berbeda bentuknya saling terkait, kemudian digerakkan oleh puting beliung. Semakin banyak atom yang bergerak menimbulkan pusat gerak atom (atom yang padat) yang disebut realitas seluruhnya adalah sebagai suatu campuran yang mengandung semua benih-benih. Setiap benda mengandung benih. Indera kita tidak dapat melihat semua benih yang ada di dalamnya. Hanya bisa melihat benih yang dominan. Misalnya, kita melihat emas (terlihat emas, karena warna kuning yang dominan), walaupun benih-benih yang lain seperti perak, besi, tembaga terdapat didalamnya (Canard, 2011).

Pemikirannya tentang nus, bahwa apa yang dikemukakan oleh Empedocles tentang cinta dan benci yang menyebabkan adanya penggabungan dan 
penceraian, maka Anaxagros mengemukakan yang menyebabkan benihbenih menjadi kosmos adalah nus, yang berarti roh atau rasio, tidak tercampur dengan benih-benih dan terpisah dari semua benda. Oleh karena ajrannya tentang nus inilah Anaxagoras untuk pertama kalinya dalam filsafat dikenal adanya perbedaan antara jasmani dan yang rohani.

10. Democritus (460-370 SM)

Democritus lahir di Kota Abdera di pesisir Thrake di Yunani Utara. Karena Democritus berasal dari keluarga yang kaya raya, maka dengan kekayaannya itu ia bepergian ke Mesir dan negeri -negeri Timur lainnya. Dari karya-karyanya ia telah mewariskan sebanyak 70 karangan tentang bermacam-macam masalah seperti, kosmologi, matematika, astronomi, logika, etika, teknik, mesin, puisi dan lain-lain. Sehingga Democritus dipandang sebagai seorang sarjana yang menguasai banyak bidang.

Pemikirannya, bahwa realitas bukanlah satu, tetapi terdiri dari banyak unsur dan jumlahnya tak terhingga. Unsur-unsur tersebut merupakan bagian materi yang sangat tidak dapat dibagi-bagi lagi. Unsur tersebut dikatakan sebagai atom yang berasal dari satu dari yang lain karena ini tidak dijadikan dan tidak dapat dimusnahkan, tidak berubah dan tidak berkualitas. Menurut pendapatnya, atom-atom itu selalu bergerak, berarti harus ada ruang yang kosong. Sebab satu atom hanya dapat bergerak dan menduduki satu tempat saja. Sehingga Democritus berpendapat bahwa realitas itu ada dua, yaitu: atom itu sendiri (yang patuh) dan ruang tempat atom bergerak (kosong) (Wilkinson, 2000).

Democritus pun membedakan adanya dua macam pengetahuan, yaitu pengetahuan indera yang keliru dan pengetahuan budi yang sebenarnya. Democritus mengatakan bahwa ada dua pengetahuan katanya, pengetahuan yang sebenarnya dan pengetahuan yang tidak sebenarnya. Adapun yang tidak sebenarnya adalah penglihatan, penciuman, rasa.

\subsection{Neo Fytagoras, Neo Plato dan Neo Aristoteles}

Neo Pythagoreanism (atau Neo-Pythagoreanism) adalah sekolah filsafat Helenistik yang menghidupkan kembali doktrin Pythagoras. Neo Pythagoreanisme dipengaruhi oleh Platonisme Tengah dan pada gilirannya mempengaruhi Neoplatonisme. Itu berasal dari abad ke-1 SM dan berkembang selama abad ke-1 dan ke-1 M. The 1911 Britannica menggambarkan Neo 
Pythagoreanisme sebagai "penghubung dalam rantai antara yang lama dan yang baru" dalam filsafat Helenistik. Inti dari pemikiran Neo Pythagoras adalah konsep jiwa dan keinginan inherent untuk unio mystica dengan yang ilahi. Kata "Neo Pythagoreanisme" adalah istilah modern (abad ke-19), yang dibuat sebagai paralel dari "Neoplatonisme". Pada abad ke-1 SM, teman Cicero, Nigidius Figulus, berusaha menghidupkan kembali doktrin Pythagoras, tetapi anggota terpenting sekolah itu adalah Apollonius dari Tyana dan Moderatus dari Gades pada abad ke-1 M. Neo Pythagoras penting lainnya termasuk matematikawan Nicomachus dari Gerasa (fl. $150 \mathrm{M}$ ), yang menulis tentang sifat mistik angka. Pada abad ke-1, Numenius dari Apamea berusaha untuk memadukan unsur-unsur tambahan Platonisme ke dalam Neo Pythagoreanisme, yang menggambarkan kebangkitan Neoplatonisme, (Iamblichus, khususnya, sangat dipengaruhi oleh Neo Pythagoras Isme) (Matthews, 2003).

Neo Pythagoras Isme adalah upaya untuk memasukkan kembali unsur mistik religius ke dalam filsafat Helenistik (didominasi oleh kaum Stoa) menggantikan sesuatu yang kemudian dianggap sebagai formalisme yang gersang. Para pendiri sekolah berusaha untuk menanamkan doktrin mereka dengan halo tradisi dengan menganggapnya berasal dari Pythagoras dan Plato. Mereka kembali ke periode pemikiran Platon selanjutnya, periode ketika Platon berusaha untuk menggabungkan doktrin Ide dengan teori bilangan Pythagoras, dan mengidentifikasi Kebaikan dengan Monad (yang akan memunculkan konsep Neoplatonik Yang Esa ), sumber tentang dualitas yang tak terbatas dan yang diukur dengan skala realitas yang dihasilkan dari yang Esa hingga objekobjek dunia material.

Zaman Aristoteles menekankan perbedaan mendasar antara jiwa dan tubuh. Tuhan harus disembah secara spiritual dengan "Doa" dan keinginan untuk menjadi baik, bukan dalam tindakan lahiriah. Jiwa harus dibebaskan dari materi yang mengelilinginya, "jubah berlumpur pembusukan", dengan kebiasaan hidup asketis. Kenikmatan jasmani dan semua dorongan inderawi harus ditinggalkan karena merugikan kemurnian spiritual jiwa. Tuhan adalah prinsip kebaikan, Materi dasar dari Kejahatan. Dalam sistem ini dapat dibedakan tidak hanya asketisme Pythagoras dan mistisisme kemudian Plato, tetapi juga pengaruh misteri Orphic dan filsafat Oriental. Ide-ide Platon tidak lagi merupakan entitas yang berdiri sendiri tetapi merupakan elemen yang merupakan konten aktivitas spiritual. Alam semesta non-material dianggap sebagai bidang pikiran atau roh (Miquel, et al., 2011). 
The Basilica Maggiore Porta, menyatakan mana Neo Pythagoreans mengadakan pertemuan mereka di abad ke-1, diyakini telah dibangun oleh keluarga Status, ditemukan di dekat Porta Maggiore di Via Prenestina di Roma (ditemukan 1915).

\section{Interpretasi alegoris dari Plato}

Banyak penafsir Platon berpendapat bahwa tulisan-tulisannya mengandung bagian-bagian dengan makna ganda, yang disebut 'alegori' atau 'simbol', yang memberikan lapisan makna kiasan pada dialog di samping makna literalnya yang biasa. Interpretasi alegoris tentang Plato ini dominan selama lebih dari seribu lima ratus tahun, dari sekitar abad pertama Masehi hingga Renaisans dan hingga abad ke-18, dan didukung oleh tokoh-tokoh besar seperti Plotinus, Proclus, dan Ficino. Dimulai dengan Philo dari Alexandria (1 abad M), pandangan ini mempengaruhi penafsiran Yahudi, Kristen dan Islam atas kitab suci mereka. Mereka menyebar secara luas di zaman Renaisans dan berkontribusi pada mode untuk alegori diantara penyair seperti Dante, Spencer, dan Shakespeare Adam, 2012).

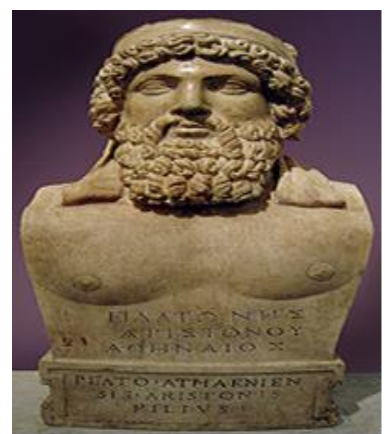

Gambar 3.1 Prasasti Yunani bertuliskan Plato

Herm dari Plato. Prasasti Yunani bertuliskan 'Plato [putra] dari Ariston, Athena' (Roma, Museum Capitoline, 188). Pada periode modern awal, ilmuwan klasik menolak klaim bahwa Platon adalah seorang alegoris. Setelah perpecahan ini, para pengikut kuno Plato yang membaca dialog sebagai alegori berkelanjutan diberi label 'Neo-Platonis' dan dianggap sebagai penyimpangan. Setelah artikel perintis Tate tahun 1919 'Plato and Allegorical Interpretation', para sarjana mulai mempelajari pendekatan alegoris ke Plato dalam dirinya sendiri baik sebagai latar belakang penting untuk studi Platon dan sebagai episode penting dalam 
sejarah filsafat, sastra kritik, hermeneutika, dan simbolisme sastra. Para sejarawan menolak pembagian sederhana apapun antara Platonisme dan NeoPlatonisme, dan tradisi membaca Platon secara alegoris sekarang menjadi bidang penelitian aktif (Bahrani, 1998).

Definisi 'alegori', 'simbolisme', dan 'makna kiasan' berkembang seiring waktu. Kata 'alegori' (Yunani untuk 'mengatakan yang lain') menjadi lebih sering pada abad-abad awal $\mathrm{M}$ dan merujuk pada bahasa yang memiliki arti lain selain arti biasa atau harfiahnya. Sebelumnya di Athena klasik, lebih umum untuk berbicara tentang 'merendahkan' (Gk., Hyponoiai), yang merujuk pada makna tersembunyi atau lebih dalam. Saat ini, alegori sering dikatakan sebagai urutan metafora yang berkelanjutan dalam sebuah karya sastra, tetapi ini bukanlah definisi kuno yang jelas sejak saat itu, satu bagian atau bahkan nama bisa menjadi alegoris. Secara umum, makna yang berubah dari istilah-istilah tersebut harus dipelajari dalam setiap konteks sejarah (Scheffler, 2003).

\section{Allegori dalam dialog Plato}

Alegori Yunani bisa dibilang dimulai dengan personifikasi dalam mitologi Yunani (Eros adalah cinta, Athena adalah kebijaksanaan). Alegori filosofis Yunani mungkin dimulai dengan Parmenides atau Empedocles tetapi jelas dalam teman Socrates, Prodicus the Sophist, dan kisahnya yang terkenal tentang 'Hercules at the Crossroads'. Dibahas oleh Xenophon, Neo-Platonis, dan banyak lainnya, itu menjadi terkenal lagi di Abad Pertengahan dan Renaissance. Di sebelah kiri, Kebajikan memanggil Hercules ke jalan kejayaan yang lebih tinggi melalui kesulitan, sementara Wakil membujuknya menuju kehidupan yang mudah dan menyenangkan (Annibale Carracci, The Choice of Hercules , detail, 1596, Museum Nasional Capodimonte).

\section{Papyrus Oxyrhynchus, dengan fragmen Republik Plato}

Sebagai seorang pemuda, Plato menghadapi perdebatan di sekitar Anaxagoras dan Socrates mengenai apakah puisi Homer mengandung alegori. Platun mengacuh pada perdebatan ini dan membuat alegori dan sifat alegori sebagai tema yang menonjol dalam dialognya. Dia menggunakan banyak berangkat alegoris dan secara eksplisit menarik perhatian padanya. Dalam Perumpamaan Gua, misalnya, Plato menceritakan kisah simbolik dan menafsirkan unsur- 
unsurnya satu per satu (Rep., 514al ff.). Dalam Phaedrus, Socrates mengkritik mereka yang menawarkan penjelasan alegoris dan rasional untuk mitos (119c6 ff.). Pandangan Platun sendiri tentang interpretasi alegoris, atau 'alegoresis', telah lama diperdebatkan. Ford menyimpulkan bahwa:

Allegoresis dipandang oleh Platon sebagai metode yang tidak pasti dan berbahaya jika menyangkut anak-anak, tetapi dia tidak pernah menyangkal secara langsung kemungkinan penggunaannya secara lebih filosofis. Dalam bagian yang menolak alegori dari Republik (378d), alasan utamanya adalah pedagogis dan sosial daripada teologis atau metodologis. Keresahan Platon difokuskan pada popularis penafsiran halus, bukan pada metode itu sendiri.

Inti dari filsafat Plato adalah Teori Bentuk (atau Ide), dan banyak penulis telah melihat dalam teori metafisika ini sebagai pembenaran untuk penggunaan alegori sastra. Fletcher, misalnya, menulis:

Teori ide-ide Platonis memiliki dua aspek yang mengarah pada interpretasi alegoris dari tanda dan benda, Untuk berbicara tentang "ide tentang sesuatu" hampir memanggil proses alegoris, karena ide itu melampaui hal itu, seperti halnya sang alegoris fiksi berangkat dari pengertian literal suatu ucapan. Yang lebih penting adalah pengaturan Platonis dari teori gagasan sebagai konstruksi hierarkis yang luas, dari bentuk yang lebih rendah ke bentuk yang lebih tinggi. Mempertanyakan nilai esensial dari alam material, dialektika Platonis terbuka jalan menuju spiritualisasi alam, dan dalam kasus Platon sendiri hal ini mengarah pada penggunaan alegori tepat pada saat dalam dialognya ketika analisis alam telah mencapai titik transendensi tertinggi yang dapat dijelaskan dalam istilah alamiah manusia (Thompson, 2004).

Banyak yang percaya bahwa Plato dipengaruhi oleh Pythagoras. Seperti sekte kuno lainnya, mereka terkenal memiliki doktrin rahasia dan ritual rahasia. Penulis kuno, bagaimanapun, secara khusus menghubungkan mereka dengan 'simbol' yang digunakan untuk menyembunyikan rahasia mereka. Orang Pythagoras tampaknya memperluas arti istilah ini untuk memasukkan frasa pendek yang memainkan peran sandi rahasia atau menjawab teka-teki ritual. Menelusuri cara penggunaan ini diperluas lebih lanjut untuk mencakup simbolisme sastra dan dengan demikian mengapa Pythagoras kadang-kadang dikreditkan dengan penemuan simbolisme tersebut Gmirkin, 2006).

\section{Penerjemah awal Plato}

Sebuah organisasi atau akademi, perselisihan terkenal tentang mitos penciptaan dalam Timaeus Plato menunjukkan bahwa beberapa pengikut awal Plato tidak 
membaca dialog secara harfiah: Speusippus, Xenocrates, dan Polemo semuanya menafsirkan bagian kunci dalam Timaeus secara kiasan. Setelah Aristoteles meninggalkan Akademi dan mendirikan sekolahnya sendiri, dia tampaknya tidak berbagi ambivalensi terhadap alegori yang diungkapkan dalam dialog Plato yang menganggap mitos Yunani kuno, misalnya, sebagai ekspresi alegoris dari kebenaran filosofis:

Warisan telah diturunkan dari yang paling kuno ke masa kemudian dalam bentuk mitos, bahwa ada dewa dan yang ilahi mengelilingi semua alam. Sisa [dari cerita kuno] diekspresikan secara mitos, yang sesuai untuk meyakinkan orang yang tidak berpendidikan ... Mereka bahkan mengatakan dewa memiliki bentuk manusia dan mirip dengan hewan lain Jika klaim pertama, bahwa mereka percaya para dewa adalah realitas fundamental, diambil secara terpisah [dari cerita mistis], kemudian mereka pasti mengucapkan kebenaran yang diilhami.

Ketika Aristoteles membahas bagian-bagian dalam dialog Platon, dia menafsirkannya secara harfiah. Tulisan Aristoteles menentang Pythagoras Isme dan umumnya kata-kata yang tidak jelas dalam pidato publik. Aristoteles menunjukkan bahwa siswa langsung Platon biasanya membaca dialog secara harfiah atau bahwa Aristoteles sendiri tidak pernah diinisiasi ke dalam sekte Pythagoras dan dengan demikian melewatkan alegori yang kemudian ditemukan pembaca dalam dialog (George, 2003).

Dua abad setelah kematian Plato pada 347 SM, terdapat minat yang berkelanjutan pada filosofi Plato tetapi hanya sedikit bukti yang bertahan dari upaya hati-hati di antara para pengikut awalnya untuk menafsirkan dialog (ini tidak, tentu saja, dimaksudkan untuk memberikan pandangan Platon sendiri). Generasi pertama 'dogmatis' setelah Platon di Akademi awal umumnya prihatin dengan doktrin, argumen, dan masalah Platon, tetapi tidak dengan pembacaan rinci teks-teks Platon. Rupanya tidak ada komentar tentang dialog yang ditulis di awal Akademi sampai Crantor (meninggal sekitar 190 SM). Para dogmatis diikuti oleh 'skeptis' yang menafsirkan dialog terutama sebagai profesi ketidaktahuan Socrates. Dörrie menunjukkan bahwa gagasan menafsirkan teksteks Platon secara komprehensif belum muncul:

Pertanyaan Hermeneutics [tentang bagaimana menafsirkan teks-teks Platon] tidak diajukan. Saat ini, tuntutan penafsiran harus berangkat dari evaluasi keseluruhan (des gesamten Habitus) teks tampak jelas dan bahkan dangkal. Namun, bahkan dalam filologi modern, tuntutan ini pertama kali diakui valid dalam dua atau paling banyak tiga generasi terakhir. 


\section{Pergantian alegoris: Neo-Pythagorean}

Ketika minat pada Plato menyebar dari Athena ke Aleksandria dan kota-kota lain di seluruh Mediterania, ada perubahan dari doktrin yang dianut oleh Akademi menuju pembacaan langsung dialog itu sendiri. Sejak periode ini dan seterusnya, pendekatan alegoris untuk membaca Plato semakin menjadi norma. Pergeseran bersejarah ini bertepatan dengan kebangkitan minat dalam Pythagoras Isme sekitar abad pertama SM. Neo-Pythagoras seperti Numenius segera mulai mengklaim bahwa doktrin Pythagoras secara simbolis tertanam dalam dialog Plato. Salah satu karya Numenius berjudul On the Disagreement of the Academics with Plato dan On the Secrets atau Reserved Doctrines in Plato. Tarrant meringkas pandangan Neo-Pythagoras, mengatakan bahwa mereka percaya (cetak miring asli):

Platonisme Tengah kadang-kadang dianggap menghindari interpretasi alegoris, tetapi survei Dillon menemukan 'kesinambungan relatif' dengan Neo-Platonis kemudian: 'setidaknya pada akhir akhir periode Platonis Tengah, ada perkembangan dalam penafsiran yang mengantisipasi sampai batas tertentu alegoris dari Neo-Platonis. 'Atribusi rutin makna tersembunyi Plato di antara Platonis Tengah dapat ditemukan, misalnya, di Plutarch (c. 45 - $115 \mathrm{M}$ ), seorang pendeta misteri Elysian dan mungkin penerus Platonis (Rendsburg, 2007).

\section{Dominasi Plato alegoris: Neoplatonisme}

Penggambaran paling awal dari lemari buku atau armarium Romawi, dengan gulungan di dalam di rak atas. Dari sarkofagus bertanggal 100-300 M, kira-kira pada waktu Plotinus berada di Roma. Meskipun ditemukan di Ostia, sebuah pelabuhan dekat Roma, prasasti Yunani menunjukkan seorang penduduk Yunani. Kotak terbuka berisi alat bedah di bagian atas kabinet, gulungan lainnya, dan baskom untuk pasien yang mengalami pendarahan di dalam kabinet menyarankan seorang dokter terpelajar.

Sejarawan modern menyebut pengikut Plato pada abad-abad awal Masehi sebagai 'Neo-Platonis'. Mereka adalah pendukung paling penting dan kuat dari interpretasi alegoris Plato. Plotinus, yang dianggap sebagai pendiri NeoPlatonisme, sering mengatakan bahwa dialog-dialog Plato mengandung 'perusakan' (hyponoiai). Nya Ennead III.5 adalah penafsiran alegoris diperpanjang ayat-ayat dari Plato Symposium (Karen et al., 1998).

Komentar yang bertahan tentang dialog Plato oleh Neo-Platonis seperti Proclus mengandung interpretasi alegoris yang diperluas. Komentar Proclus tentang Plato's Parmenides mengatakan, misalnya, narator Antiphon tidak mungkin 
mengabaikan 'rahasia' atau 'makna yang lebih dalam' dialog.Proclus sendiri melihat karakter dialog sebagai simbol prinsip metafisik: Parmenides adalah representasi ilahi, Zeno dari Akal, dan Socrates dari Akal tertentu. Proclus secara umum berpendapat bahwa:

Tulisan-tulisan dengan karakter yang benar-benar mendalam dan teoritis tidak boleh dikomunikasikan kecuali dengan sangat hati-hati dan penilaian yang dipertimbangkan, jangan sampai kita secara tidak sengaja mengekspos ke pendengaran yang jorok dan mengabaikan publik pemikiran tak terekspresikan dari jiwa-jiwa seperti dewa Proclus mengklaim bahwa Parmenides umumnya mengkomunikasikan maknanya melalui alegori atau merendahkan. Seorang guru, katanya, tidak 'berbicara dengan jelas, tetapi menjadi puas dengan adanya indikasi; karena seseorang harus mengungkapkan kebenaran mistik secara mistik dan tidak mempublikasikan doktrin rahasia tentang para dewa '(918). Metode pengajaran dialog adalah 'menggunakan simbol dan indikasi dan tekateki, metode yang sesuai dengan doktrin yang paling mistis (Richard et al., 2010)

Seorang neo-Platonis akhir, Macrobius menunjukkan bahwa pada abad kelima $\mathrm{M}$, penafsiran alegoris tentang Plato bersifat rutin: Itulah sebabnya Plato, ketika tergerak untuk berbicara tentang Kebaikan, tidak berani mengatakan apa itu ... para filsuf menggunakan narasi yang luar biasa (fabulosa); Bukan tanpa tujuan, bagaimanapun, atau hanya untuk menghibur, tetapi karena mereka menyadari bahwa eksposisi yang jujur dan telanjang (apertam nudamque) tentang dirinya tidak disukai oleh Alam, yang, sama seperti dia menahan pemahaman tentang dirinya sendiri dari pengertian kasar manusia. Hal menyelimuti dirinya dalam pakaian beraneka ragam, juga ingin agar rahasianya ditangani oleh individu yang lebih bijaksana melalui narasi yang luar biasa. Hanya orang-orang terkemuka dengan kecerdasan yang lebih tinggi yang mendapatkan wahyu tentang kebenarannya (Sheila, 2005).

\subsection{Filsafat Zaman Mesopotamia}

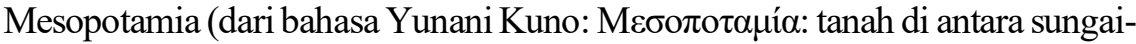
sungai; bahasa Arab: bilād al-rāfidayn; bahasa Suriani: (Beth Nahrain): "tanah dari sungai-sungai" terletak di antara dua sungai besar, Eufrat dan Tigris. Daerah yang kini menjadi Republik Irak itu pada zaman dahulu disebut Mesopotamia, yang dalam bahasa Yunani berarti "(daerah) di antara sungai-sungai". Dengan bidang tanah yang panjang dan sempit berbentuk seperti bulan sabit dan tanahnya yang subur, daerah ini juga disebut "Bulan Sabit Subur". Nama Mesopotamia sudah digunakan oleh para penulis Yunani dan Latin kuno, seperti 
apa Polybius (abad 1 SM) dan Strabo (60 SM-10 M). Tanah subur ini telah menumbuhkan banyak peradaban kuno yang megah dan secara kolektif dikenal sebagai sebagai peradaban Mesopotamia. Inilah peradaban paling awal di Asia Barat dan salah satu yang tertua di dunia (Roux, 1993).

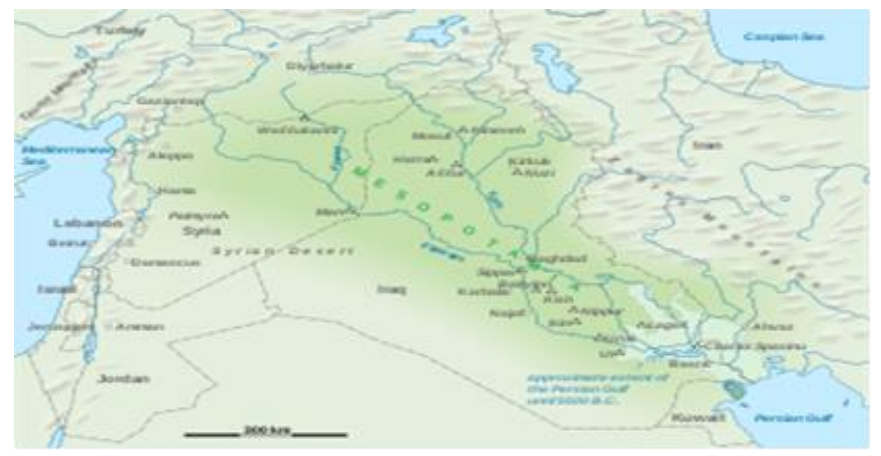

Gambar 3.2 Peta yang menunjukkan wilayah Mesopotamia

Menurut keyakinan Kristen dan Yahudi seperti dalam Perjanjian Lama, ada usaha menghubungkan keluarga Abraham (yang lalu disebut "Bapa Orang Beriman" dan diakui oleh tiga agama monoteistik dunia, Islam, Kristen, dan Yahudi) dengan Mesopotamia. Dalam kitab Kejadian 11:31 dikatakan, pada suatu masa keluarga Abraham berpindah dari Ur Kasdim ke Hairan sebelum akhirnya berpindah ke Kanaan (Daerah Israel dan Palestin sekarang) (Robert, 2004).

Lokasi Ur Kaśdim biasanya dirujuk pada Tell el-Muqayyar, situs bekas reruntuhan Kota Ur kuno dari periode Sumeria. Sedangkan Haran terletak di bagian utara Mesopotamia, di tepi Sungai Efrat.

daerah Mesopotamia berasal dari akar kata Yunani Kuno $\mu$ ćбos (mesos)

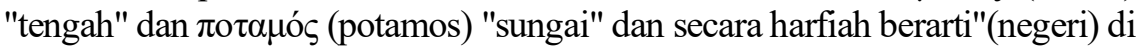
antara sungai-sungai". Toponimi ini digunakan dalam Septuaginta yang berbahasa Yunani itu (ca. $150 \mathrm{SM}$ ) sebagai terjemahan dari padanannya dalam bahasa Ibrani yaitu Maharahim. Toponimi ini bahkan sudah lebih awal digunakan oleh bangsa Yunani sebagaimana yang dibuktikan dengan Anabasis Alexandri, yang ditulis pada akhir abad ke-1 Masehi, namun secara khusus mengacu pada sumber-sumber dari zaman Alexander Agung. 
Anabasis, Mesopotamia digunakan untuk menyebut wilayah yang membentang di timur Sungai Efrat di utara Suriah. Istilah Aram birit/birit Narim berhubungan dengan konsep geografis serupa.Kemudian, istilah Mesopotamia itu lebih umum diterapkan untuk semua tanah antara sungai Eufrat dan Tigris, sehingga menggabungkan tidak hanya bagian dari Suriah tetapi juga hampir semua Irak dan Turki tenggara.Dataran stepa di sebelah barat sungai Eufrat dan bagian barat Pegunungan Zagros juga sering termasuk dalam istilah yang lebih luas Mesopotamia.Perbedaan lebih lanjut biasanya dibuat antara atas atau Utara Mesopotamia dan dataran yang rendah atau Selatan Mesopotamia.Mesopotamia utara juga dikenal sebagai Jazirah, adalah daerah antara Eufrat dan Tigris sampai ke Baghdad.Mesopotamia selatan terdiri dari Irak selatan, Kuwait, dan Iran bagian barat. Dalam penggunaan akademis modern, istilah Mesopotamia juga memiliki konotasi kronologis. Sering kali digunakan untuk merujuk daerah ini sampai dengan masa Penaklukan Muslim. Nama-nama seperti Suriah, Jezirah, dan Irak digunakan untuk menggambarkan wilayah tersebut setelah masa ini setelah ini telah diperdebatkan bahwa eufimisme ini merupakan istilah Eurosentris yang disematkan pada daerah ini pada masa-masa perambahan orang Barat abad ke-19 (Winter, 1985).

Mesopotamia meliputi wilayah antara Sungai Eufrat dan Tigris yang sama-sama bersumber dari Dataran Tinggi Armenia. Kedua sungai ini juga mendapatkan tambahan pasokan air dari banyak anak sungai, dan keseluruhan jaringan sungai ini mengaliri wilayah bergunung-gunung yang sangat luas. Jalur perjalanan darat di Mesopotamia lazimnya menyusuri Sungai Efrat karena tepian Sungai Tigris sebagian besar terjal dan sukar dilalui. Iklim wilayah ini semi-gersang dengan bentangan gurun yang luas di utara serta bentangan daerah berawa-rawa, berlumpur, dan bergelagah seluas $15.000 \mathrm{Km}$ persegi (5.800 Mil persegi) di selatan. Jauh di ujung selatan, Eufrat dan Tigris menyatu dan bermuara ke Teluk Persia.

Lingkungan gersang yang membentang dari kawasan-kawasan pertanian tadah hujan di daerah utara sampai ke daerah selatan di mana pertanian dengan irigasi menjadi sangat penting jika orang mengharapkan perolehan surplus energi yang dihasilkan atas energi yang diinvestasikan (Energy Returned on Energy Invested, EROEI). Irigasi ini dipermudah oleh tingginya permukaan air tanah dan lelehan salju dari puncak-puncak tinggi Pegunungan Zagros di wilayah utara dan dari dataran tinggi Armenia, sumber air Sungai Tigris dan Efrat yang menjadi asal-muasal nama negeri itu. Manfaat irigasi bergantung pada kemampuan mengerahkan tenaga kerja yang memadai untuk membuat dan memelihara saluran-saluran air. Maka, faktor ini yang sejak permulaan zaman 
telah membantu pertumbuhan pemukiman-pemukiman perkotaan dan sistem kekuasaan politik yang terpusat Fensham, 1962).

Usaha pertanian di seluruh wilayah Mesopotamia disokong oleh usaha penggembalaan ternak secara berpindah-pindah. Kaum pengembara yang mendiami kemah-kemah menggembalakan biri-biri dan kambing (dan kemudian unta) dari padang-padang penggembalaan sepanjang sungai pada bulan-bulan di musim panas yang kering, menuju padang-padang rumput musiman di sepanjang perbatasan dengan gurun pada musim dingin yang basah. Wilayah Mesopotamia umumnya tidak memiliki batu-batu untuk bahan bangunan, logam mulia, dan kayu, karena itulah sepanjang sejarahnya bergantung pada perniagaan jarak jauh atas hasil-hasil pertanian untuk mendapatkan barang-barang langka itu dari luar wilayah. Di daerah rawa-rawa di selatan, terdapat suatu budaya rumit penangkapan ikan dengan kapal-kapal pengangkut semenjak zaman prasejarah, yang menambah keberagaman budaya Mesopotamia.

Kegagalan-kegagalan berkala dalam sistem budaya ini diakibatkan oleh sejumlah faktor. Kebutuhan tenaga kerja dari waktu ke waktu telah mengakibatkan peningkatan populasi yang mendesak batas-batas daya tampung ekologi, dan saat wilayah ini mengalami masa kekacauan iklim, keruntuhan pemerintah pusat dan penurunan populasi dapat terjadi. Di lain pihak, kerentanan militer terhadap serangan dari suku-suku pinggiran dari daerah perbukitan atau padang-padang penggembalaan telah mengakibatkan keruntuhan perniagaan dan penelantaran jaringan-jaringan irigasi selama beberapa waktu. Demikian pula, kecenderungan-kecenderungan memusat yang ada di negara-negara kota hanya pemerintahan terpusat atas seluruh wilayah Mesopotamia. Bilamana dipaksakan, cenderung berumur pendek, dan semangat kedaerahan pun terpecah-belah kekuasaan yang utuh menjadi satuan kesukuan atau kedaerahan yang lebih kecil. Kecenderungan semacam ini masih terus berlanjut di Irak sampai sekarang (Dunham, 2005).

\section{Sejarah Mesopotamia:}

Sejarah Mesopotamia diawali dengan tumbuhnya sebuah peradaban, yang diyakini sebagai pusat peradaban tertua di dunia, oleh bangsa Sumeria. Bangsa Sumeria membangun beberapa kota kuno yang terkenal, yaitu Ur, Ereck, Kish, dll. Kehadiran seorang tokoh imperialistik dari bangsa lain yang juga mendiami kawasan Mesopotamia, bangsa Akkadia, dipimpin Sargon Agung, ternyata melakukan sebuah penaklukan politis, tetapi bukan penaklukan kultural. Bahkan dalam berbagai hal budaya Sumeria dan Akkadia berakulturasi, 
sehingga era kepemimpinan ini sering disebut Jilid Sumeria-Akkadia. Campur tangan Sumeria tidak dapat diremehkan begitu saja, pada saat Akkadia terdesak oleh bangsa Gutti, bangsa Sumeria yang mendukung Akkadia, sehingga mereka masih dapat berkuasa di "tanah antara dua sungai-sungai" itu.

\section{Mesopotamia dalam Alkitab:}

Beberapa catatan lain bisa dikemukakan untuk menunjukkan hubungan antara Abraham dengan Mesopotamia. Dalam Kitab Ulangan 16:3; Nabi Musa mengajak umat untuk berdoa kepada Tuhan saat mempersembahkan panel pertama dengan mengawalnya, Bapaku adalah seorang Ara, seorang pengembara. Di tempat lain dikatakan bahwa Ishak, anak Abraham, diperintah Abraham untuk mencari istri dari daerah Aram-Mesopotamia (aram-naharayim) (Kejadian 14:1,10). Demikian juga dengan Yaakub, cucu Abraham, dia disuruh pergi ke Padan-Aram untuk mendapatkan istri di sana. Terjemahan Yunani Septuaginta, kedua nama terakhir ini disebut Mesopotamia.

\section{Bagian potongan dari Epic Gilgamesh dalam bahasa Akkadia}

Selain petunjuk yang secara eksplisit ada dalam Alkitab, masih bisa ditemukan informasi lain yang menunjukkan pengaruh Mesopotamia yang cukup kuat. Kesejajaran antara kisah-kisah Enkidu/Shamhat dan Adam/Hawa telah lama diakui oleh para peneliti. Kisah Taman Eden dan kisah Air Bah yang terkenal itu, yang dikisahkan pada bagian awal kitab Kejadian, sebenarnya kuat dipengaruhi sastra Mesopotamia. Biasanya ada tiga karya sastra Mesopotamia yang ditunjuk, yaitu Enuma Elish (abad 17 SM), Epos Gilgames (abad 10 SM), dan Atrahasis (abad 18-17 SM). Teks-teks itu cukup terkenal dan tersebar luas karena ditemukan dalam berbagai versi dan bahasa, seperti versi Akkadia, Sumeria, Hittit, dan Asyur. Kemiripan antara sastra Mesopotamia dengan teksteks Alkitab begitu mencolok sehingga sering kali disimpulkan bahwa ada ketergantungan antara keduanya. Karena teks-teks Mesopotamia berasal dari periode yang jauh lebih tua dari teks-teks Alkitab, maka tidak mengherankan jika bisa disimpulkan, teks Alkitab bergantung pada sastra Mesopotamia itu. Para penulis Israel tampaknya mengambil dan memanfaatkan teks-teks Mesopotamia itu untuk mengungkap keyakinan mereka, sekaligus menyesuaikannya dengan keyakinan itu, terutama di bidang monoteisme (Dunham, 2005)

Salah satu kemungkinan datangnya pengaruh Mesopotamia dalam kitab Kejadian adalah bahwa kisah-kisah Mesopotamia dibawa ke Palestina lalu menyebar-saat terjadi perpindahan penduduk besar-besaran dari Mesopotamia 
yang disebabkan situasi yang agak kacau sekitar abad 19 SM. Kiranya ini juga yang menjadi konteks berpindahnya keluarga Abraham dari Ur ke Haran, lalu ke Kanaan (Sheila, 2005).

Berbagai kebiasaan dan peraturan yang tercermin dalam kitab Kejadian ternyata juga menemukan banyak kesamaan dengan kebiasaan dan peraturan yang hidup di daerah Mesopotamia. Sebagai contoh, kekhawatiran Abraham karena dia tidak mendapat keturunan, karena itu harus mewariskan segala miliknya kepada abdinya yang setia, Eliezer (Kejadian 15:1-4), ternyata sejajar dengan praktik yang dilakukan masyarakat Nuzi yang mendiami sebelah timur Sungai Tigris. Hal ini bisa diketahui melalui analisis teks-teks hukum yang berlaku di Nuzi, yang berasal dari abad $15 \mathrm{SM}$. Kisah tentang Abraham yang datang ke negeri asing lalu mengakui istrinya sebagai saudaranya (Kejadian 11:10-10), sering membingungkan orang. Tetapi, kini, dengan ditemukannya teks-teks yang berasal dari bangsa Hori di sebelah utara Mesopotamia, berdekatan dengan Haran, hal itu bisa dipahami dengan lebih baik. Dalam masyarakat Hori, ikatan perkawinan yang paling kuat adalah jika seorang istri sekaligus mendapat status saudara secara hukum. Karena itu, sering terjadi, sesudah perkawinan diadakan upacara lain untuk mengadopsi sang istri menjadi saudari. Hal ini disahkan dengan dua dokumen. Pertama, dokumen tentang perkawinan. Kedua, berkait dengan pengangkatannya sebagai saudari (Gmirkin, 2006).

Matthias Henze menunjukkan bahwa kegilaan Nebukadnezar dalam Kitab Daniel mengacu pada Epos Gilgames. Dia mengklaim bahwa penulis menggunakan unsur-unsur dari deskripsi Enkidu untuk melukis potret sarkastik dan mengejek raja Babel.

Salah satu warisan peradaban Mesopotamia Kuno yang amat bernilai bagi umat manusia adalah kumpulan hukum yang biasa disebut Codex Hammurabi. Kumpulan hukum yang berbentuk balok batu hitam itu ditemukan di Susa tahun 1901 dalam suatu ekspedisi yang dilakukan arkeolog Prancis di bawah pimpinan $\mathrm{M}$ de Morgan. Pada bagian atas balok, yang kini ada di Museum Louvre, Paris, ada relief yang menggambarkan Raja Hammurabi dari Babilonia Kuno (1718-1686 SM) sedang menerima hukum dari Dewa Shamash, dewa Matahari yang juga menjadi dewa pelindung keadilan. Perbandingan dengan kumpulan hukum yang ada dalam Kitab Keluaran 11-13 menunjukkan adanya kesejajaran yang dekat. Adanya ketergantungan antara kedua kumpulan hukum itu tidak bisa ditentukan dengan pasti, tetapi pengaruh tidak langsung rasanya merupakan sesuatu yang amat masuk akal (Bahrani, 1998). 
Codex Hammurabi, yang terdiri dari 181 pasal ditambah Prolog dan Epilog, tidak saja berpengaruh pada kumpulan hukum yang ada dalam Alkitab, tetapi juga pada sistem hukum pada periode selanjutnya. Yang menarik dan mungkin membuat kita (seharusnya) tertunduk malu adalah, kumpulan hukum itu juga mengingatkan kita bahwa sejak abad 18 SM, di Mesopotamia sudah ada seorang pemimpin besar yang sungguh-sungguh mempunyai kesadaran bahwa manusia harus diperlakukan secara adil sebagai manusia.

Budaya:

Patung pria Sumeria dengan sikap tubuh seorang peserta upacara pemujaan, terbuat dari pualam dengan mata dari cangkang kerang, 1750-1600 SM

\section{Hari raya:}

Bangsa Mesopotamia Kuno setiap bulan menyelenggarakan upacara-upacara. Tema upacara dan perayaan untuk tiap-tiap bulan ditentukan oleh sekurangkurangnya enam faktor utama:

Pergantian penampakan bulan (separuh-terang bermakna kelimpahan dan pertumbuhan, sedangkan separuh-gelap dikait-kaitkan dengan penurunan, pelestarian, dan perayaan "Alam Bawah")

\section{Pergantian musim bercocok-tanam}

Titik khatulistiwa matahari dan titik balik mati; hari Mitos-mitos setempat beserta dewa-dewi yang terkait dengannya Keberhasilan dari raja yang berkuasa saat itu. Istilah Akitu, atau perayaan Tahun Baru (purnama pertama sesudah matahari melintasi khatulistiwa di musim semi). Peringatan peristiwa-peristiwa bersejarah (hari pendirian, kemenangan-kemenangan perang, hari-hari suci bagi kuil, dan seterusnya) (Adam, 2012)

\section{Olahraga:}

Perburuan populer di kalangan raja-raja Asyur. Tinju dan gulat sering ditampilkan dalam seni rupa, dan beberapa bentuk permainan polo agaknya merupakan olahraga yang populer, dengan pemain yang duduk di atas pundak orang bukannya di atas punggung kuda. Mereka juga memainkan majore, sebuah permainan yang mirip rugbi, tetapi dimainkan dengan sebuah bola yang terbuat dari kayu. Mereka juga memainkan sebuah permainan papan yang mirip dengan senet dan backgammon, dan yang kini dikenal sebagai "Permainan Kerajaan dari Ur." 


\section{Ekonomi dan pertanian:}

Area-area tambang di Asia Barat Kuno. Warna kotak: coklat untuk arsen, merah untuk tembaga, kelabu untuk timah, coklat kemerah-merahan untuk besi, kuning untuk emas, putih untuk perak, hitam untuk timbal. Warna area: kuning untuk perunggu lakuran arsen, kelabu untuk perunggu lakuran timah.

Budidaya tanaman pangan yang dibantu sistem irigasi menyebar dari pegunungan Zagros ke arah selatan bersama dengan peradaban Samara dan peradaban Hadji Muhammad sejak sekitar 5,000 SM. uil-kuil Sumeria berfungsi sebagai bank dan mengembangkan sistem pinjaman dan kredit skala besar pertama, tetapi bangsa Babilonia yang mengembangkan sistem perbankan dagang yang pertama. Perekonomian Mesopotamia dalam satu dan lain hal dapat dibandingkan dengan ilmu ekonomi pasca-Keynes, tetapi dengan suatu pendekatan yang cenderung "apa saja boleh" (Miquel, 2011).

Sejak permulaan sejarah Mesopotamia sampai dengan zaman Ur III, kuil-kuil menguasai sampai dengan sepertiga dari seluruh lahan yang ada, namun jumlah itu menurun dari waktu ke waktu seiring peningkatan kepemilikan tanah oleh pihak istana dan orang-orang pribadi. Ensi adalah kata yang digunakan sebagai sebutan bagi orang yang bertugas mengatur pekerjaan untuk segala macam usaha pertanian di lahan-lahan milik kuil. Rakyat jelata diketahui sebagai golongan yang paling sering bekerja di bidang pertanian sebagai petani penggarap, khususnya di lahan-lahan milik kuil atau istana.

Kondisi geografi Mesopotamia selatan hanya memungkinkan penyelenggaraan pertanian jika dikelola dengan irigasi dan drainase yang baik. Kenyataan ini berdampak besar pada evolusi peradaban Mesopotamia awal. Kebutuhan irigasi mendorong bangsa Sumeria, dan selanjutnya bangsa Akkadia, untuk membangun kota-kota mereka di sepanjang tepian sungai Tigris dan Efrat serta cabang-cabangnya. Kota-kota besar seperti Ur dan Uruk, bertempat di sekitar anak-anak Sungai Efrat, sedangkan kota-kota lain, khususnya Lagash, didirikan dekat cabang-cabang Sungai Tigris (Canad, 2011).

Sungai-sungai juga memiliki manfaat lain sebagai sumber pasokan ikan (baik sebagai bahan pangan atau sebagai pupuk), gelagah, dan lempung (untuk bahan bangunan). Berkat irigasi, pasokan pangan di Mesopotamia sebanding dengan pasokan pangan di padang-padang rumput Kanada.Lembah sungai Tigris dan lembah Sungai Efrat merupakan bagian timur laut dari bentangan Hilal Subur yang juga meliputi lembah Sungai Yordan dan lembah Sungai Nil. Jika semakin dekat dengan sungai membuat lahan menjadi subur dan baik untuk ditanami, 
maka sebaliknya jarak yang semakin jauh dari sungai membuat lahan menjadi kering dan sebagian besar tidak dapat dihuni. Itulah sebabnya perkembangan irigasi sangat penting artinya bagi para penduduk Mesopotamia.

Inovasi bangsa Mesopotamia lainnya adalah pengendalian laju air dengan bendungan serta pemanfaatan saluran-saluran air. Orang-orang yang mula-mula menempati tanah yang subur di Mesopotamia mempergunakan luku kayu untuk menggemburkan tanah sebelum ditanami jelai, bawang, anggur, lobak, maupun apel. Penduduk Mesopotamia terbilang di antara orang-orang pertama yang membuat bir dan tuak anggur. Dilibatkannya keterampilan dalam bertani di Mesopotamia membuat para petani tidak bergantung pada budak belian untuk merampungkan pengerjaan lahan-lahan mereka, tetapi ada pula beberapa pengecualian. Tingginya risiko mempekerjakan budak belian (budak belian melarikan diri atau memberontak) membuat banyak petani menghindarinya. Meskipun sungai-sungai menjadi penyokong hidup penduduk Mesopotamia, sungai-sungai juga menghancurkannya dengan banjir yang kerap meluap dan meluluh-lantakkan seisi kota. Cuaca Mesopotamia yang sukar ditebak sering kali tidak berpihak pada para petani; tanaman-tanaman pangan sering dirusak cuaca sehingga orang perlu memelihara sumber-sumber pangan cadangan seperti lembu dan biri-biri. Seiring berlalunya waktu, daerah-daerah paling selatan di Mesopotamia menderita akibat meningkatnya kadar garam pada tanah, sehingga mengakibatkan kota-kota lambat-laun ditinggalkan orang dan terjadi pemusatan kekuasaan di Akkadia yang letaknya jauh lebih ke utara (Vahid, 1973).

\section{Pemerintahan:}

Geografi Mesopotamia sangat berdampak pada perkembangan politik di wilayah itu. Di antara sungai dan kali, orang-orang Sumeria mendirikan kotakota perdana dengan saluran-saluran irigasinya yang terpisahkan satu sama lain oleh bentangan gurun atau rawa yang luas dan terbuka, tempat berkeliaran sukusuku pengembara. Komunikasi antar kota-kota terisolasi itu sulit dan kadang berbahaya jika dilakukan. Oleh karena itu, masing-masing Kota Sumeria menjadi sebuah negara kota yang merdeka dan gigih mempertahankan kemerdekaannya. Kadang-kadang salah satu kota akan mencoba menaklukkan dan mempersatukan kota-kota yang sewilayah dengannya, tetapi upaya-upaya semacam itu mendapat perlawanan dan tertumbuk pada kegagalan selama berabad-abad. Akibatnya, sejarah politik Sumeria penuh dengan peperangan yang berlangsung tanpa henti. Pada akhirnya Sumeria pun dipersatukan oleh Eannatum, tetapi persatuan itu rapuh dan gagal bertahan, karena bangsa Akkadia 
berjaya menaklukkan Sumeria pada 1331 SM hanya satu generasi sesudahnya. Kekaisaran Akkadia adalah kekaisaran pertama yang mampu bertahan melampaui satu generasi dan menyelenggarakan alih kepemimpinan raja-raja secara damai. Umur kekaisaran ini relatif singkat, karena ditaklukkan bangsa Babilonia setelah bertahan selama beberapa generasi (Rahman and Fazlur, 1996).

\section{Raja-raja:}

Bangsa Mesopotamia percaya bahwa raja-raja dan ratu-ratu mereka adalah keturunan dari warga Kota Dewa-Dewa, tetapi tidak seperti bangsa Mesir Kuno, mereka tidak pernah meyakini bahwa raja-raja mereka adalah dewa-dewa sejati. Sebagian besar raja-raja menggelar dirinya "raja semesta alam" atau "raja agung". Gelar lainnya yang lazim dipakai adalah "gembala", karena raja-raja harus memperhatikan peri kehidupan rakyatnya.

\section{Kekuasaan:}

Ketika tumbuh menjadi sebuah kekaisaran, wilayah kekuasaan Asyur dibagibagi menjadi daerah-daerah yang disebut provinsi. Tiap-tiap provinsi dinamakan menurut nama kota utamanya, seperti Niniwe, Samaria, Damsyik, dan Arpad. Semua provinsi dikepalai gubernurnya masing-masing yang bertugas memastikan setiap orang membayar pajaknya. Para gubernur juga wajib menghimpun pasukan untuk maju berperang dan menyalurkan tenaga kerja bila ada pembangunan kuil. Seorang gubernur juga bertanggung jawab atas penerapan hukum di provinsi yang dipimpinnya. Cara ini memudahkan pengendalian sebuah kekaisaran besar. Walaupun sebelumnya cuma sebuah negara kecil di Sumeria, Babel tumbuh pesat selama masa pemerintahan Hammurabi. Ia dikenal sebagai "pencipta aturan hukum", dan segera Babel menjadi salah satu kota utama di Mesopotamia. Kelak Babel disebut Babilonia, yang berarti "gapura dewa-dewa." Kota ini juga menjadi salah satu pusat pembelajaran terbesar dalam sejarah (Ziai, 2010).

\section{Peperangan:}

Sekeping pecahan dari Prasasti Burung Nazar yang memperlihatkan pasukan perang yang sedang berbaris, zaman dinasti awal III, 1600-1350 SM. Salah satu dari dua patung domba dalam belukar yang ditemukan di pemakaman kerajaan di Ur, 1600-1400 SM.

Berakhirnya zaman kekuasaan Uruk, tumbuh kota-kota bertembok dan banyak desa terpencil dari zaman Ubaid ditinggalkan yang menyiratkan adanya 
peningkatan kekerasan yang dilakukan secara berkelompok. Seorang raja awal yaitu Lugalbanda diduga telah membangun tembok putih mengitari kota itu. Begitu negara-negara kota mulai tumbuh, lingkup jangkauan pengaruh mereka pun saling tumpang-tindih sehingga menimbulkan perdebatan di antara negaranegara kota lainnya, khususnya menyangkut tanah dan terusan-terusan. Perdebatan-perdebatan ini dicatat pada loh-loh lempung beberapa ratus tahun sebelum pecah perang-perang besar - catatan pertama mengenai peperangan ditulis sekitar 3100 SM. Namun, belum menjadi suatu kelaziman sampai kirakira 1500 SM.

Seorang raja Dinasti Awal II (Ensi) Uruk di Sumer, Gilgamesh (1600 SM), disanjung karena keberhasilannya dalam bertempur melawan Humbaba, penjaga Pegunungan Aras, dan kelak dalam banyak sajak dan kidung ia dipujapuji pula sebagai makhluk dua pertiga dewa dan hanya sepertiga manusia. Tugu Prasasti Burung Nazar yang berasal dari akhir zaman Dinasti Awal III (1600 1350 SM), yang dibuat untuk memperingati kemenangan Eannatum dari Lagash atas kota tetangga saingannya Umma, adalah monumen tertua di dunia yang dibuat sebagai pernyataan pujian atas sebuah tindakan pembantaian. Mulai saat itu sampai seterusnya, peperangan dijadikan bagian dari sistem politik Mesopotamia. Sesekali sebuah kota yang netral dapat bertindak selaku penengah bagi dua kota yang saling berseteru. Keadaan ini mendorong terbentuknya persatuan-persatuan antar-kota yang kelak berkembang menjadi negara-negara kedaerahan. Tatkala kekaisaran-kekaisaran terwujud, mereka pun maju berperang tetapi lebih sering melawan negara-negara asing. Raja Sargon misalnya, menaklukkan seluruh kota di Sumeria, beberapa kota di Mari, dan kemudian maju berperang melawan Suriah utara. Banyak dinding istana Asiria dan Babilonia dihiasi dengan gambar-gambar mengenai pertempuranpertempuran yang berhasil dimenangkan dan musuh yang lari kocar-kacir atau bersembunyi dibalik rumpun-rumpun gelagah (Adib, 2010).

\section{Hukum:}

Negara-negara Kota Mesopotamia menyusun naskah hukum mereka dengan bersumber pada keputusan-keputusan peradilan dan undang-undang raja-raja. Naskah hukum Urukagina dan Lipit Isytar telah ditemukan. Naskah hukum paling terkenal berasal dari Hammurabi, yang termasyhur setelah kematiannya berkat perangkat aturan hukum yang disusunnya, yakni Naskah Hukum Hammurabi (disusun ca. $1780 \mathrm{SM}$ ), yang merupakan salah satu perangkat hukum tertua yang pernah ditemukan dan salah satu contoh dokumen sejenis yang berasal dari Mesopotamia Kuno. Hammurabi menetapkan 100 lebih aturan 
hukum bagi Mesopotamia. Kajian atas aturan-aturan ini menunjukkan makin lemahnya hak-hak perempuan, dan makin kejamnya perlakuan terhadap budak belian

Seni rupa:

Seni rupa Mesopotamia menyaingi Seni rupa Mesir Kuno baik dari segi kemegahan, kecanggihan, maupun tingkat kerumitannya di kawasan barat Eurasia sejak milenium ke-4 SM sampai wilayah itu ditaklukkan Kekaisaran Akhemeniyah Persia pada abad ke-6 SM. Peninggalan seni rupa Mesopotamia sebagian besar berupa jenis patung batu dan tanah liat yang sangat tahan lama sifatnya; hanya sedikit peninggalan berupa lukisan yang mampu mencintai zaman, namun peninggalan-peninggalan itu menyiratkan bahwa lukisan-lukisan Mesopotamia umumnya berupa pembubuhan warna pada pola-pola hiasan geometris dan tumbuh-tumbuhan, meskipun sebagian besar patung-patung juga diwarnai (Adam, 2012).

Pada zaman melek-aksara perdana, tatkala Mesopotamia berada di bawah kekuasaan Uruk, dihasilkan karya-karya yang canggih seperti Bejana Warka dan stempel-stempel silinder. Singa Betina Guennol adalah sebuah patung batu gamping kecil yang menarik dari Alam sekitar 3000-1800 SM, berwujud separuh manusia dan separuh singa. Tidak lama sesudah zaman itu, muncul sejumlah patung berwujud imam-imam dan pemuja-pemuja bermata besar, sebagian besar terbuat dari pualam dengan tinggi mencapai satu kaki, yang tampak tengah menghadiri upacara penyembahan berhala di kuil, namun hanya sejumlah kecil patung-patung ini yang menyintas Patung-patung dari zaman Sumeria dan Akkadia umumnya bermata besar membelalak dan berjanggut panjang pada sosok pria. Banyak pula mahakarya yang telah ditemukan di makam kerajaan di Ur (ca. $1650 \mathrm{SM}$ ), termasuk dua patung domba dalam belukar, lembu tembaga, dan sebuah kepala lembu pada salah satu di antara liralira dari Ur.

Zaman berikutnya sebelum bangkitnya Kekaisaran Assyria Baru, seni rupa Mesopotamia menyintas dalam beberapa wujud yaitu stempel-stempel silinder, patung-patung utuh yang relatif kecil, dan relief-relief dalam berbagai ukuran, termasuk plakat-plakat murah dari gerabah cetakan untuk rumah tinggal, sebagian berkaitan dengan keagamaan dan sebagian lagi tampaknya tidak. Relief Burney adalah sebuah plakat terakota dengan tingkat kerumitan yang tidak seperti biasanya dan relatif besar ukurannya $(10 \times 15$ inci) memperlihatkan sosok dewi bersayap dan berkaki burung pemangsa, dikawal burung-burung hantu dan singa-singa. Relief ini berasal dari abad ke-18 atau ke-19 SM, dan 
mungkin pula merupakan hasil cetakan. Tugu-tugu batu prasasti, persembahanpersembahan nazar, atau plakat-plakat peringatan kemenangan-kemenangan perang dan pesta-pesta perayaan, ditemukan pula di kuil-kuil, yang tidak seperti barang-barang sejenis keluaran pemerintah yang lebih resmi sifatnya, tidak memuat cukup banyak tulisan untuk menjelaskan barang-barang itu; Kepingan tugu Prasasti Burung Nazar adalah sebuah contoh awal peninggalan barangbarang bertulisan, dan Obelisk Hitam Shalmaneser III dari Asyur adalah peninggalan bertulisan yang besar dan kokoh dari zaman kemudian (Bahrani, 1998).

Ditaklukkannya seluruh Mesopotamia dan wilayah-wilayah di sekitarnya oleh bangsa Asyur menjadikan negeri itu lebih besar dan lebih makmur daripada sebelumnya, serta dipajangnya karya seni yang sangat memukau di istana-istana dan tempat-tempat umum dimaksudkan pula untuk menyaingi semarak seni rupa negeri tetangga mereka, Kekaisaran Mesir. Bangsa Asyur mengembangkan sebuah gaya seni berupa latar-latar yang sangat luas diisi relief-relief pipih naratif yang ditata dengan sangat rinci pada batu untuk istanaistana, menampilkan adegan-adegan peperangan atau perburuan; British Museum memiliki sekumpulan relief semacam itu. Bangsa Asyur menghasilkan sangat sedikit patung yang dipahat utuh, kecuali untuk sosok-sosok raksasa penjaga, kerap kali berwujud lamassu berkepala manusia, yang dipahat menjadi relief timbul pada dua sisi balok persegi, dengan bagian kepala berupa pahatan utuh (dan juga kelima tangannya, sehingga tampak terpahat utuh dari masingmasing sisi balok). Bahkan sebelum menguasai Mesopotamia mereka telah meneruskan tradisi pembuatan stempel silinder dengan rancangan-rancangan yang sering kali tampak hidup dan penuh cita rasa seni.

Arsitektur:

Kajian mengenai seni bina Mesopotamia Kuno didasarkan pada bukti-bukti arkeologi yang tersedia seperti gambar-gambar berwujud bangunan, dan naskah-naskah tentang pelaksanaan pembangunan. Karya-karya ilmiah biasanya terkonsentrasi pada kuil-kuil, istana-istana, tembok-tembok dan gerbang-gerbang kota, serta bangunan-bangunan monumental lainnya. Namun, sesekali dihasilkan pula karya ilmiah terkait seni bina rumah tinggal. Survei permukaan dalam lingkup arkeologi juga telah memungkinkan pembuatan kajian mengenai tata ruang perkotaan di Kota Mesopotamia awal.

Batu-bata merupakan bahan bangunan yang paling banyak digunakan karena tersedia dekat dan terjangkau, sedangkan batu bangunan harus didatangkan dari tempat-tempat yang cukup jauh dari sebagian besar kota-kota itu. Ziggurat 
adalah bentuk bangunan yang paling menonjol, dan kota-kota seringkali memiliki gerbang-gerbang besar. Yang paling masyhur dari gerbang-gerbang itu adalah Gerbang Isytar dari Kota Babel yang dibangun pada era Babilonia Baru, dihiasi hewan-hewan yang dibentuk pada batu-bata beraneka warna, dan sebagian besar kini menjadi koleksi Pergamon Museum di Berlin ((adam, 2012).

Sisa-sisa bangunan yang paling menonjol dari zaman awal Mesopotamia adalah gugus-gugus bangunan kuil di Uruk dari milenium ke-4 SM, kuil-kuil dan istana-istana di situs-situs periode Dinasti Awal di lembah Sungai Diyala seperti Khafajah dan Tell Asmar, sisa-sisa peninggalan Dinasti ketiga Ur di Nippur (Tempat suci Enlil) dan Ur (Tempat suci Nanna), sisa-sisa peninggalan dari pertengahan Zaman Perunggu di situs-situs Suriah-Turki seperti Ebla, Mari, Alalakh, Aleppo dan Gultepe, istana-istana dari akhir Zaman Perunggu di Bogazkoy (Hattusa), Ugarit, Asyur dan Nuzi, istana-istana dan kuil-kuil Zaman Besi di situs-situs Assiria (Kalhu/Nimrud, Khorsabad, Nineveh), Babilonia (Babel), Urartu (Tushpa/Van, Kalesi, Çavuştepe, Ayanıs, Armavir, Erebuni, Bastam) dan Het Baru (Karkamis, Tell Halaf, Karatepe).

Rumah-rumah sebagian besar diketahui dari sisa-sisa peninggalan era Babilonia Baru di Nippur dan Ur. Yang menonjol dari antara sumber-sumber tertulis mengenai pendirian bangunan dan ritual-ritual yang terkait dengannya adalah silinder-silinder Gudea dari milenium ke-3 SM, demikian pula prasasti-prasasti kerajaan Assyria dan Babilonia dari Zaman Besi (Wilkinson, 2000).

\subsection{Filsafat dan Teori Eksoterik dan Esoterik}

Dalam Agama Terlembaga di seluruh dunia (dan juga dalam berbagai aliran kepercayaan), baik secara resmi maupun tidak resmi, terdapat para penganut yang termasuk golongan eksoteris dan para penganut yang termasuk golongan esoteris. Ibaratnya seperti film layar-lebar, orang-orang eksoterisnya adalah para pemain figuran (jumlahnya sampai ribuan dalam film kolosal) dan sedikit orang esoterisnya merupakan beberapa pemain inti (termasuk di dalamnya bintang utama protagonis dan antagonisnya) yang jumlahnya relatif sangat sedikit jika dibandingkan dengan para 'bolo dupakan' ('figuran' dalam dialek Jawa) yang disebut terdahulu. Persis sama dalam hal jumlah, kaum esoteris dalam agama 
dan aliran kepercayaan apapun biasanya merupakan mayoritas, sedangkan kaum esoterisnya adalah minoritas (George, 2003).

Jelas sekali bedanya kaum eksoteris dan esoteris ini dalam hal: tingkat pengetahuan dan pemahaman agamanya. Ibaratnya lautan, pengetahuan dan pemahaman kaum esoteris agama adalah ibarat gelombang yang tinggal di permukaan belaka, yang bergerak ke sana dan ke sini sesuai dengan tiupan angin; ada beberapa jenis gelombang yang sangat mengasyikkan bagi peselancar spiritual dan ada pula yang setinggi gunung menggulung segala yang lewat di dalamnya, apa saja. Ada pula yang memorakrandakan keseluruhan yang dilewatinya tanpa ampun layaknya gelombang Tsunami. Sebaliknya, pemahaman kaum esoteris ibaratnya adalah kedalaman lautan yang tenangtenang menghanyutkan dan mengandung kekuatan yang tidak terperikan. Para penghuni kedalaman lautan juga sangat khusus. Para ikan spiritual yang tidak memiliki kemampuan khas ikan khusus laut dalam jangan mencoba-coba menyelam sampai kedalaman lautan karena selain mereka tidak akan bertahan hidup, kedalaman lautan itu sama sekali bukanlah habitatnya yang memberinya kenyamanan dan kebahagiaan.

Sebagai contoh saja, marilah kita memakai permisalan dalam agama Islam, meskipun seperti yang saya nyatakan di atas, kedua golongan ini terdapat dan berlaku bagi para penganut agama dan para anggota organisasi spiritual apa saja di dunia ini. Khazanah Islam, pada umumnya para muslim berpengetahuan seperti para anggota Kompasiener di sini tentu mengenal betul istilah dan makna 'maqom' (syariat, tarikat, hakikat, makrifat). Nah, kaum esoteris yang boleh dikatakan merupakan 'bolo dupakan' spiritual sebagian besar menjejali 'maqam syariat' ini. Entah mereka itu secara fisik berjulukan kyai, ustads, atau para ikhwan awam biasa, jika mereka masih tergolong eksoteris, ya mereka mau tidak mau mesti puas jika disebut masih berada pada maqom syariat. Maqom tarikat, menurut saya pribadi, adalah maqom yang paling berbahaya bagi para pengikutnya karena ibaratnya mereka naik perahu, mereka menaruh satu kaki di satu perahu syariat (eksoteris) dan satu kakinya lagi terpancang di perahu tarikat (semi esoteris) (karen, 1998).

Jadi, sebelum orang syariat berlaku 'nekat' memasuki dunia tarekat, ia mesti mempersiapkan diri dulu dengan sebaik-baiknya untuk mempelajari segala persyaratan dengan tekun dan seksama dan berusaha semampu-mampunya memenuhi persyaratan, dan jika diperlukan berguru dengan Master Kungfu Wong Fei Hung atau magang di kuil Shaolin di Tiongkok sana, dalam hal keseimbangan tubuh dan kekuatan kuda-kuda kaki, tentunya jika ia tidak ingin 
kecemplung laut digerogoti hiu atau kecemplung sungai menjadi santapan empuk buaya. Saya pernah mengenal beberapa ikhwan tarikat tertentu yang bukannya meningkat maqom atau kadar spiritualitasnya malah boleh dikatakan agak terganggu jiwa-raganya karena belum memenuhi prasyarat keseimbangan dan kekuatan kuda-kuda kaki, sudah berani-beraninya menaruh masing-masing kakinya di dua perahu.

Khusus untuk maqom hakikat dan makrifat, jelas sekali saya tidak perlu bersusah payah menerangkannya dalam tulisan ini karena akan sama sekali tidak berguna. Mengapa? Para pembaca yang masih berada dalam maqam syariat alias kaum eksoteris, maaf, pasti tidak akan memahaminya atau palingpaling akan menyalah tafsirkan nya dan mengubah tulisan ini menjadi fitnah (inilah yang tidak saya inginkan) dan menimbulkan badai polemik berkepanjangan dan para pembaca yang Alhamdulillah telah menapaki jalan esoteris jelas sekali tidak memerlukan penjelasan apapun dari saya karena tentu mereka sudah tahu sendiri (Robert, 2004).

Kaum eksoteris agama dan organisasi spiritual apapun di dunia ini biasanya memiliki kadar rasa takut sangat tinggi (baca artikel sebelumnya) yang terjelma atau tercermin dalam perkataan (atau tulisan), perilaku, sikap, tingkah laku, perbuatan, atau tindakan dalam kehidupan sehari-harinya. Ingatlah bahwa ketika kita membicarakan penyakit atau racun rasa takut ini, jangan lupakan penyakit/racun turunannya seperti rasa tidak percaya diri, gemar melarikan diri dari kenyataan, suka berbohong, suka munafik, penuh dengan kebencian, kebodohan, berprasangka buruk, mudah menghakimi orang yang berpaham lain, gampang curiga, menghalalkan segala cara dengan memberi pembenaran atas perilakunya tersebut, dsb., dst. Orang yang menapaki jalan esoteris jelas telah menipis kadar rasa takutnya, dan bahkan pada suatu titik tertentu rasa takut itu benar-benar lenyap dari dalam dirinya. Ia telah mengalami transformasi total.

Rasa takut ini tidak akan mampu dihilangkan atau dikurangi oleh si aku/ego yang merupakan biang rasa takut itu sendiri. Yang mampu dilakukan oleh si ego dalam hal ini hanyalah menekan rasa takut yang malah semakin berbahaya bagi kesehatan jiwa-raga orang yang bersangkutan, karena pengaruh keterkondisian syariat agamanya, biasanya berkeinginan kuat untuk melenyapkan penyakit rasa takut ini, namun ibarat kepala ular yang berusaha mengejar dan ingin memakan ekornya sendiri, ia hanya berputar-putar dalam kebingungan. Sesuai dengan isi tulisan ini, resep yang sangat manjur telah tersedia, yakni menampakkan diri ke dalam jalan esoteris. Sekalipun demikian, banyak persiapan yang perlu dilakukan, antara lain masalah keseimbangan dan kekuatan seperti yang saya 
umpamakan di tas. Jalan lurus telah tersedia di mana pun Anda kini berada, pilihan berada di tangan Anda (Winter, 1985).

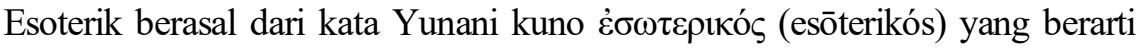
suatu hal yang diajarkan atau dapat dimengerti oleh sekelompok orang tertentu dan khusus, dapat juga berarti suatu hal yang susah untuk dipahami. Esoterik berasal dari kata esotericism (esoterisme) yakni pemikiran filsafat mengenai proses evolusi dari manusia dan makhluk hidup lainnya. Ilmu tentang akumulasi dari kebijaksanaan dari zaman ke zaman. Menampilkan sebuah sekumpulan pemikiran yang sistematis dan komprehensif tentang struktur semesta dan letak manusia dalam semesta tersebut. Mendeskripsikan kekuatan dan pengaruh yang terdapat di dalam dunia yang fenomenal dan sebuah proses untuk mewaspadai dan mengerti kekuatan tersebut.

Esoteris juga disebut sebagai ilmu mengenai roh yang terdapat di setiap benda dan mempunyai terminologi, percobaan-percobaan, deduksi-deduksi dan hukum-hukum. Hal ini secara mudah diartikan sebagai suatu hal yang terdapat di luar daya tangkap dan daya pikir manusia biasa dan mewakilkan sebuah proses evolusi makhluk hidup dari suatu titik dasar: Bagaimana semesta dapat tercipta, bagaimana kinerjanya dan peran manusia di dalamnya. Esoteris juga kadang disebut sebagai seni untuk bekerja bersama energi-energi dengan kedekatan bersama sumber spiritual tertinggi. Ajaran-ajaran ini telah membantu untuk membimbing dan membentuk peradaban demi peradaban yang berdampak terhadap kemajuan yang dialami oleh umat manusia baik dalam hal ilmu pengetahuan, politik, seni atau agama (Nasr, 1997).

\subsection{Metode Induktif dan Deduktif}

Pengertian Induktif :

Penalaran induktif adalah cara berpikir yang berdasar pada kejadian yang khusus untuk memastikan teori, hukum, konsep yang umum. induktif diawali dengan mengutarakan teori yang memiliki batasan eksklusif pada saat membuat pernyataan yang diakhiri dengan pernyataan yang memiliki karakter umum. (Jujun.S.Suriasumantri: 2005)

Metode Induktif : 
Pendekatan induktif terdiri dari tiga langkah, berikut merupakan langkah beserta contoh penelitian induktif:

1. Observasi atau Pengamatan :

- Penerbangan maskapai bertarif rendah ditunda

- Kucing A dan B memiliki kutu

- Kehidupan kera bergantung pada air

2. Amati polanya :

- 30 penerbangan pada maskapai bertarif rendah ditunda

- Semua kucing yang diamati memiliki kutu

- Keberadaan semua hewan yang diamati bergantung pada air

3. Mengembangkan teori :

- Maskapai berbiaya rendah selalu mengalami penundaan

- Semua kucing memiliki kutu

- Semua kehidupan biologis bergantung pada air

Keterbatasan induktif:

Kesimpulan yang diambil atas dasar metode induktif tidak pernah dapat dibuktikan, tetapi dapat dibatalkan.

Contoh: Peneliti telah mengamati 100 penerbangan dari maskapai penerbangan bertarif rendah. Semuanya mengalami penundaan, yang sesuai dengan teori peneliti. Namun, peneliti tidak pernah bisa membuktikan bahwa penerbangan 101 juga akan ditunda. Namun, semakin banyak data yang dikumpulkan maka keakuratan kesimpulan bisa semakin bisa diandalkan.

Pengertian Deduktif :

Penalaran deduktif adalah cara berpikir yang mengimplementasikan sesuatu yang umum dan selanjutnya dikaitkan dengan aspek-aspek yang sesuatu yang khusus. Secara umum arti dari deduksi itu sendiri adalah penarikan kesimpulan dari situasi yang umum, memperoleh yang khusus dari hal yang umum (Partenie, 2003). 
Pendekatan atau metode deduktif merupakan sesuatu yang memakai logika untuk membuat satu atau lebih kesimpulan berlandaskan beberapa premis yang diberikan. Pada deduktif yang rumit peneliti bisa membuat kesimpulan lebih dari satu.

\section{Metode deduktif:}

Pendekatan penelitian deduktif terdiri dari empat langkah. Di bawah ini adalah langkah dengan contoh penelitian deduktif:

1. Mulai dengan teori yang sudah ada

- Maskapai berbiaya rendah selalu mengalami penundaan

- Semua kucing memiliki kutu

- Semua kehidupan biologis bergantung pada air

2. Merumuskan hipotesis berdasarkan teori yang ada

- Jika penumpang terbang dengan maskapai berbiaya rendah, maka akan selalu mengalami penundaan

- Semua kucing peliharaan yang ada di lingkungan peneliti (satu lingkungan kos) mempunyai kutu

- Keberadaan semua mamalia darat bergantung pada air

3. Kumpulkan data untuk menguji hipotesis

- Kumpulkan data penerbangan maskapai bertarif rendah

- Uji semua kucing yang ada di sebuah lingkungan peneliti (satu lingkungan kos) apakah ada kutu

- Pelajari semua spesies mamalia darat untuk melihat apakah mereka bergantung pada air

4. Analisis hasil: apakah menolak atau menerima hipotesis?

- 3 dari 100 penerbangan maskapai bertarif rendah tidak ditunda $=$ tolak hipotesis. 



\section{Bab IV \\ Konsep Filsafat Pendidikan Kebangsaan Cokroaminoto}

\subsection{Pendidikan Kebangsaan Tinjauan Sosial Cokroaminoto}

Pencapaian nilai-nilai sosial tidak terlepas pada dimensi pendidikan kebangsaan berbasis tauhid dan hal tersebut mesti diawali dalam lingkaran keluarga sebagai pendidikan pertama. Ini yang dimaksudkan Peter M. Blau dengan pemanfaatan hukum-hukum formal yang termodifikasi dalam suatu struktur kerana itu lebih efisien dalam pencapaian tujuan suatu program. Di lingkungan keluargalah seorang Cokroaminoto dibentuk dan dibangun karakternya dengan pendidikan agama. Dimana pada lingkungan keluarganya Nama lengkap Cokroaminoto adalah Haji Oemar Said Cokroaminoto dan disingkat H.O.S. Cokroaminoto yang pada ulasan ini disebut Cokroaminoto. Kehidupan Cokroaminoto bersama kedua orang tuanya dan saudara-saudara dengan pendidikan agama karena selain orang tuanya sebagai seorang kyai juga seorang pimpinan pesantren, ini artinya Cokroaminoto diwajibkan belajar agama dan sedikit banyaknya beliau paham agama (Abdullah, 2011).

Konsep pendidikan kebangsaan Cokroaminoto dari tinjauan teori struktur Fungsional Robert K. Merton (1910-1003) telah menjadi suatu jalan menuju 
transformasi sosial di berbagai generasi pada zamannya. Pendidikan kebangsaan dengan konsep penanaman nilai-nilai sosial tidak hanya tentang hak asasi manusia, namun juga sebagai alat strategis dalam membangun masyarakat agar lebih akrab dan menyatu pada satu tujuan yaitu kecintaan tanah air yang menuju pada ilmu tauhid. Konsep pendidikan sosial kebangsaan yang mengarah pada terciptanya solidaritas yang dibangun Cokroaminoto telah mampu menyadarkan masyarakat dan komunitas pentingnya suatu pemahaman ketauhidan menuju persatuan dan kesatuan. Pembelajaran agama dalam lingkungan keluarganya Taufik, 1977).

Cokroaminoto menyadari pentingnya hubungan sosial, karena agama dan kehidupan sosial memiliki hubungan keterkaitan yang sangat mendalam, bahkan agama melalui Al-Qur'an telah menjelaskan segala sesuatu apa yang ada di dunia ini. Sebagaimana pendapat dalam teori fungsionalnya menyatakan bahwa manfaat yang diharapkan individu bukan harus terjadi pada saat itu, tetapi sekurang-kurangnya dapat dirasakan pada waktu di masa-masa akan datang. Hal ini selaras dengan pemikiran Cokroaminoto, dimana Cokroaminoto yang memiliki strata sosial yang tinggi namun Cokroaminoto lebih memilih menggunakan nama dan lebih senang dipanggil Haji Oemar Said dibandingkan dengan Raden Haji Oemar Said (Abede, 2010).

Pemahaman dan ideologi hidup dengan mengedepankan nilai-nilai pendidikan sosial berbasis tauhid sudah menjadi karakter Cokroaminoto, sehingga hal tersebut pun ditanamkan dalam berbagai organisasi dimana Cokroaminoto berafiliasi. Konsep sosial yang dibangun Cokroaminoto dalam organisasi SDI dan SI telah mengakar ke semua struktur dan menjadi pondasi penanaman jiwa kebangsaan. Jiwa kebangsaan yang menjadi doktrin Cokroaminoto melalui organisasi seperti penanaman solidaritas sosial yang menuju pada persamaan hak, persatuan, keberanian pada kebenaran yang berpedoman pada nafas Islam, yaitu Al-Qur'an dan Al-Hadits. Selain itu, nilai sosial yang cenderung pada ketauhidan yang mengakar pada diri Cokroaminoto tetap dibarengi pada suatu komitmen dan ketegasan sehingga semua individu dan masyarakat menghormati serta menghargainya. Menyimak hal tersebut dapat ditarik kesimpulan bahwa nilai pendidikan sosial dan kesederhanaan Cokroaminoto yang tercipta dalam suasana keluarganya sangat luar biasa dan patut menjadi contoh bagi semua generasi. Selain itu juga patut menjadi contoh dalam mendidik setiap generasi baik dalam lingkungan luar maupun dalam pendidikan formal tentang pentingnya nilai-nilai sosial yang bersandar pada ilmu tauhid dalam kehidupan (Abror, 2008) 
Konsep pemikiran pendidikan kebangsaan Cokroaminoto terhadap pendidikan kebangsaan diwarnai oleh dasar pemahaman keislaman dalam perspektif Tauhid. Disini sangat fundamental karena, dengan melalui pendidikan kebangsaan dengan berbasis pada nilai-nilai Tauhid akan membentuk sikap dan perilaku individu yang pada prinsipnya akan berfungsi sebagai aqidah dan falsafah hidup bagi diri individu untuk bangsanya. Fundamentalnya pendidikan kebangsaan dengan balutan nilai-nilai Tauhid karena ruang kehidupan sangat berkaitan aqidah Islam, dan aqidah dalam Islam merupakan pondasi bagi keberagaman seseorang dan benteng yang kokoh untuk memelihara aqidah muslim dari setiap ancaman keraguan dan kesesatan baik dalam sistem kepemimpinan, bermasyarakat serta berbagai aspek dalam kehidupan di muka bumi ini. Pendidikan kebangsaan berbasis ilmu tauhid merupakan jalan pembentukan karakter individu menuju masyarakat peduli sosial dan stabilitas yang menitik beratkan pada keseimbangan antara ilmu agama dan ilmu umum (Agbor, 2008).

Kedalam kabangsaan dan nasionalisme serta jiwa sosial yang dibungkus dengan pondasi nasionalisme Islam juga telah menjadi jalan dalam memperkokoh budaya masyarakat. Ide sosialisme Cokroaminoto juga mempunyai konsep untuk pemberdayaan masyarakat dengan mengedepankan nilai-nilai budaya keagamaan dalam setiap kelompok-kelompok sosial. Oleh karena itu, melalui pendidikan tauhid dalam konteks budaya dan pemahaman agama sebagai ruang budaya masyarakat atau individu akan lebih mengedepankan nilai-nilai moralitas dan saling menghargai sebagaimana pendapat Thomas Lickona dan Nurul Zuriah bahwa pengetahuan nilai moral itu tidak cukup sebagai manusia dengan karakter nasional, nilai moral sebaiknya disertakan dengan komponen karakter yang baik (components of good character), pengetahuan tentang moral (moral knowing), perasaan tentang moral (moral feeling), dan perbuatan yang bermoral (moral actions)". Hal ini dibutuhkan untuk manusia agar mampu memahami, merasakan, dan sekaligus mengerjakan nilai-nilai kebajikan dalam dialektika kehidupan sebagaimana harapan Cokroaminoto. Pemantapan nilainilai kebangsaan melalui budaya mesti merangkul semua aspek dalam kehidupan manusia sebagaimana pada Gambar 8.1 di bawah dan mesti ditanamkan pada setiap diri individu (Ali, 1975).

Konsep pemikiran sosial Cokroaminoto senantiasa dalam bingkai keislaman dan kebangsaan, dan jika diterapkan pada ruang organisasi politik. Gerakan politik Cokroaminoto yang menjadi nilai pendidikan dan mesti ditransformasikan ke semua generasi mengenai kebijakan yang berdasarkan kepentingan masyarakat bukan karena kepentingan individu, kelompok dan 
golongan. Sebagaimana pendapat Lyman, SM. (1995) dan Fend, H. (1001) rekonstruksi suatu lembaga menuju kesedaran moden kerana melibatkan kualitas dan manfaat lembaga-lembaga pendidikan dalam memberikan pembelajar nilai kebangsaan untuk pembangunan individu dan inovasi masyarakat untuk memenuhi tuntutan perubahan sosial dalam konteks masyarakat global. Selain itu, Cokroaminoto dalam gerakan politik islamnya semuanya berdasarkan pada kepentingan kedaulatan dan cinta pada ibu pertiwi. Konsep tersebut mengasumsikan bahwa jiwa patriotism Cokroaminoto terhadap masyarakat dan tanah air begitu dalam dan menjadi contoh serta menjadi virus untuk semua anak bangsa (Alo, 2005).

Konsep yang dijadikan acuan sebagai dasar pendidikan kebangsaan yang dicitacitakan Cokroaminoto agar semua masyarakat memilikinya dan memahaminya sebagai tujuan dalam berdialektika. Sebagaimana dijelaskan bahwa religius merupakan konsep perbuatan yang taat dalam menjalankan ajaran agama yang dianutnya, bertoleransi kepada penyelenggaraan ibadah agama lain, juga hidup rukun bersama penganut agama lainnya sebagaimana pendapat diperlukan kemampuan kesadaran dan jiwa toleran agar mampu menyesuaikan berbagai komposis persoalan. Hal tersebut sangat sejalan dengan konsep perilaku yang harus berdasarkan pada usaha membuat dirinya menjadi orang yang senantiasa dipercaya dalam ucapan, tindakan, dan pekerjaan. Sementara sikap toleransi dan perbuatan yang menghargai perbedaan agama, suku, etnis, pendapat, sikap, dan tindakan orang lain yang tak sama dari dirinya merupakan unsur yang tak bisa dipisahkan dari konsep religius dan perilaku untuk diri individu. Oleh karena itu, perlu disiplin perbuatan yang memperlihatkan perbuatan yang tertib dan patuh pada semua ketentuan dan peraturan (Yusuf, 1995).

Semangat dan kerja keras sebagai bentuk perbuatan yang bersungguh-sungguh untuk mengatasi banyaknya hambatan dalam belajar dan tugas, serta menuntaskan pekerjaan secar baik-baik. Dengan demikian berpikir kreatif dan membuat sesuatu untuk memperoleh cara atau hasil baru dari sesuatu yang telah menjadi miliknya. Maka sikap mandiri dan perbuatan yang tak mudah menyusahkan orang lain dalam menyelesaikan berbagai hal mesti ditiadakan dari diri individu karena membawa dampak pada pelemahan berpikir luas, mandiri dan demokratis yang berdampak pada ketergantungan dan mengakibatkan penjajahan moral dan wibawa. Sebagaimana hasil penelitian Mumford, dan Gustafson, \& Tsai , bahwa dalam dunia yang kompetitif saat ini, kreativiti ialah satu-satunya persoalan yang paling konstan di dalam melakukan perubahan dalam dunia pendidikan termasuk sistem pendidikan kebangsaan. 
Pola dan cara berfikir demokratis, merupakan bentuk sikap, dan bertindak untuk menilai persamaan hak dan kewajiban dirinya dan orang lain. Dengan demikian, secara rasional harus berpikir demokratis atau tidak terbatas, karena secara otomatis menumbuhkan rasa ingin tahu, tingkah laku yang selalu berupaya untuk mengetahui secara dalam dan luas dari sesuatu yang dipelajarinya, dilihat, dan didengar. Ini yang disebut dengan semangat kebangsaan karena dalam berpikir, berwawasan, dan bertindak selalu mengutamakan kepentingan bangsa dan negara dari kepentingan diri dan kelompoknya, dari dasar itulah, pondasi dari konsep cinta tanah air akan terbentuk dengan sendirinya melalui cara berfikir, bersikap, dan berbuat yang memperlihatkan kesetiaan, kepedulian, dan penghargaan yang tinggi kepada bahasa, lingkungan fisik, sosial, budaya, ekonomi, dan politik bangsa (Alrasyid, 2012).

Kecintaan dan nasionalisme terhadap tanah air Indonesia mengharuskan agar lebih mengedepankan sikap menghargai prestasi dan tindakan yang memacu dirinya supaya memperoleh sesuatu yang berguna untuk masyarakat, dan mengakui karya anak bangsa, serta menghargai kesuksesan orang lain. Karena dapat berdampak negatif bila tidak tercipta nilai saling menghargai suatu karya anak bangsa. Ini yang dimaksud oleh Dahrendorf, R. , Novri Susan dan Alo Liliweri kesan terjadinya konflik kerana adanya ketidak sesuaian antara perilaku dan tindakan dalam suatu sistem tertentu yang membuat individu tertekan. Justru itu, kesadaran sosial mesti ditumbuhkembangkan melalui persahabatan atau komunikatif dengan mengimplementasikan nilai-nilai kebangsaan berbasis tauhid dalam bentuk tindakan yang menunjukkan perasaan yang senang berkomunikasi, berteman, dan bekerja sama dengan orang lain.

Sikap cinta damai tak terlepas pada jiwa individu sebab hal tersebut merupakan perkataan dan sikap yang membuat orang lain merasa senang dan nyaman atas keberadaannya. Oleh karena itu, sangat diperlukan sikap peduli lingkungan, sikap peduli sosial dan sikap tanggungjawab sebagai bentuk tindakan seseorang untuk menunaikan tugas dan kewajibannya, yang sebaiknya dia lakukan, kepada diri sendiri, masyarakat, lingkungan, negara dan terhadap Tuhan Yang Maha Esa (Amalia, 2005).

Konsep pemikiran pendidikan kebangsaan Cokroaminoto lebih mengarah pada penanaman nilai-nilai kebangsaan yang bersumber pada nilai Al-Qur'an dan Hadits. Bangunan pendidikan kebangsaan dengan bersandar pada Qur'an dan Hadits lebih memperkokoh hubungan kehidupan sosial secara holistic, juga lebih memperdalam sikap nasionalisme yaitu cinta tanah air. Pemikiran pendidikan kebangsaan Cokroaminoto yang bersumber Al-Qur'an dan Hadits 
pada usia dini yang secara kontekstual harus dimulai dalam lingkungan keluarga sampai pada ruang kehidupan yang lainnya. Mantapnya pendidikan kebangsaan akan lebih memperjelas identitas individu dan komunitas terhadap tanah air-nya.

\subsection{Keluarga Sebagai Pondasi Pendidikan Kebangsaan Berbasis Tauhid}

Kebersamaan dalam keluarga merupakan wadah pendidikan utama bagi Cokroaminoto, dimana keluarga adalah dasar utama untuk menyusun kesiapan individu dan struktur kepribadian. Anak-anak sedikit banyaknya terbentuk dalam lingkungan keluarga dengan cara, mengikuti orang tua melalui berbagai kebiasaan dan perilaku dengan demikian keluarga merupakan unsur pendidikan lain yang paling nyata, tepat dan memiliki pengaruh yang hebat terhadap penanaman nilai-nilai kebangsaan. Oleh karena itu, salah satu elemen utama dalam membangun entitas-entitas pendidikan, mewujudkan aktivitas sosial yang alami, membuat kepribadian-kepribadian juga memberi banyaknya kebiasaan baik, semuanya dimulai dari lingkungan keluarga. Sebagaimana pandangan George Herbert Mead (1863-1931) bahwa makna dan pemikiran ialah sesuatu yang penting untuk memahami manusia di mana watak-watak mereka sebagai antipati terhadap proses sosial. Kreativitas pengetahuan semua kelemahan proses-proses pendidikan kebangsaan dalam keluargan mesti di perbeharui untuk menciptakan proses transformasi social yang lebih alami dan tetap sasaran (Amelz., 1952).

Keluarga menurut Cokroaminoto, memiliki pengaruh yang besar terhadap terbentuknya karakter individu juga terbentuknya vitalitas dan kenyamanan dalam pikiran anak-anak sebab melalui keluarga, anak-anak mempunyai bahasa, nilai-nilai, serta kecenderungan mereka . Oleh karena itu, keluarga memiliki tanggung jawab dalam mendidik anak-anak secara tepat sesuai kriterianya, jauh dari penyimpangan. Oleh sebab itu, dalam keluarga mempunyai banyak tugas dan tanggung jawab diantaranya sebagai penanggungjawab selamatnya faktor-faktor cinta kasih, baik cinta tanah air maupun love solidarity serta selalu menjaga kedamaian, menghilangkan kekerasan dan keluarga wajib mendampingi proses berlangsungnya pendidikan anak. 
Fungsi lembaga pendidikan keluarga selain sebagai medan sosial pengalaman pertama bagi generasi, juga sebagai pendidikan pembentukan emosional dan ketauhidan. Tercapainya pendidikan emosional dan ketauhidan yang baik didalam lingkungan keluarga akan berdampak secara positif pada kehidupannya dimana pun mereka berada. Oleh karena itu, pencerminan yang harus ditransfer ke setiap generasi seperti sikap saling menolong, tenggang rasa agar tumbuh kembang kehidupan sosial yang damai dan sejahtera, dan tak boleh lepas pada dasar pendidikan agama dan sosial (Beheshtifar, et al.,2013).

Pendidikan kebangsaan haruslah memiliki prinsip dasar untuk membentuk nilai-nilai kebangsaan dan harus tetap konsisten pada lembaga yaitu pendidikan keluarga karena keluarga sebagai lembaga pendidikan yang pertama dan utama dalam membentuk jati diri generasi penerus bangsa. Anak-anak yang lahir dalam suatu keluarga merupakan aset yang utama generasi pembangunan nasional, karenanya harus dibentuk untuk berkarakter yang kokoh dan memiliki jati diri bangsanya. Pewarisan nilai-nilai budaya ketauhidan sangat tepat dilakukan di lembaga keluarga, sebab bagi keluarga pendidikan adalah modal awal bagi berkembangnya kepribadian anak pada masa dewasanya.

Perspektif Keislaman Cokroaminoto yang menekankan pendidikan kebangsaan mesti dimulai dari lingkungan keluarga juga didukung oleh para ahli pendidikan bahwa usia anak pada tiga tahun pertamanya merupakan fase terbentuknya susunan otak, sementara pada usia tujuh tahun otak hampir terbentuk dengan sempurna. Pada umur-umur tersebut, umumnya waktu bagi anak tinggal di rumah. Dengan demikian keluarga begitu mempengaruhi terciptanya karakter yang mendasar, sejalan dengan urutan perkembangan otak tersebut. Sehingga pembentukan mindset ketauhidan mesti secara terus-menerus di tanamkan (Bogdan, 2006).

Pandangan Cokroaminoto terkait dengan pendidikan kebangsaan mengasumsikan lemahnya pendidikan nilai-nilai kebangsaan berbasis tauhid dalam keluarga akan membawa dampak pada pengaruh globalisasi yang berdampak terhadap pelemahan nasionalisme. Karena transformasi menuju globalisasi dapat memunculkan krisis multidimensional yang memberi pengaruh terhadap berkembangnya karakter manusia seperti krisis identitas dalam diri individu, keluarga dan masyarakat. Sebagaimana pandangan Heilbroner yang menyatakan bahwa "masa depan atau esok hari hanya dapat dibayangkan dan tidak dapat dipastikan (Brackman, 1963).

Masa depan tidak dapat diramalkan. Manusia hanya bisa melaksanakan pengawasan secara efektif pada kekuatan-kekuatan terbentuknya masa depan 
pada hari ini. Dengan kata lain masa depan ialah masa kini yang diarahkan oleh manusia itu sendiri. Jika manusia masa kini, tidak mengetahui kemungkinankemungkinan yang akan ada serta kekuatan-kekuatan yang dapat membawa kehidupan ummat manusia di masa mendatang yang tak dikenalinya, maka akan lahir suatu penyaki sosial akibat ketidaksadarannya16 Sebagaimana pernyataan Cokroaminoto bahwa memperdalam ilmu pengetahuan merupakan hal yang wajib bagi manusia, tetapi mesti seimbang dan bersandarkan pada pengetahuan agama yaitu Al-Qur'an dan Al-Hadits, agar individu mampu mengimplementasikan ke jalan yang lebih tepat dan berguna bagi masa depan bangsa dan generasinya . Sejalan dengan pendapat Heilbroner, bahwa manusia yang tak mempunyai pengetahuan akan masa mendatangnya akan terbawa oleh dahsyatnya arus perubahan ke tempat yang tidak dikenalnya sehingga melahirkan suatu kehidupan ketidakpastian, ketidakjelasan yang menuju pada chaos" (Budiardjo,,1999).

Merujuk kembali pada dinamika kehidupan latar belakang keluarga Cokroaminoto yang begitu kental pada islamisasi, dari lingkungan inilah Cokroaminoto dibentuk sampai dewasa sehingga semua ide dan konsepkonsepnya tak terlepas dari pandangan agama Islam. Justru itu, Cokroaminoto memandang bahwa terbentuknya alam spiritual dan moral anak bangsa ialah keluarga sebagai lembaga pendidikan awal. Pendidikan nilai di dalam keluarga adalah hal utama untuk manusia bertahan menjadi bermartabat dan memiliki jati diri yang utuh akan tanah airnya. Pendidikan nilai ini tak dapat dititipkan pada lembaga pendidikan formal saja, atau kepada pemerintah, atau secara sepenuhnya diserahkan pada masyarakat, tetapi dimulai dan dibingkai dalam kehidupan keluarga (Budiarjo, 1986).

Filsafat pendidikan keluarga merupakan awal dari segala hal tentang pendidikan kebangsaan yang dibentuk oleh Cokroaminoto untuk murid-muridnya seperti Sukarno dan yang lainnya. Kekeliruan dalam membimbing menjadi peluang yang besar terjadinya banyak distorsi terhadap diri anak. Dalam konteks keindonesiaan, pendidikan bagi keluarga terasa semakin sangat urgensinya, ketika terjadi suatu kenyataan buruk dalam kondisi kehidupan bangsa Indonesia. Sebagaimana fenomena yang terjadi sekarang ini, dimana tingginya tingkat korupsi, banyaknya penyalahgunaan wewenang dan jabatan, serta maraknya penyimpangan moral, yang menandakan belum bagusnya kualitas pendidikan kebangsaan, termasuk pendidikan tauhid dalam keluarga (Budiarjo, 1986).

Pandangan Cokroaminoto dalam mengatasi banyaknya persoalan moral bangsa Indonesia, tak sekedar memberikan pendidikan moral. Karena moral tak bisa 
berdiri sendiri, tetapi saling berhubungan dan dipengaruhi oleh aspek yang lain. Oleh karena itu, usaha yang perlu diupayakan ialah pendidikan yang memiliki corak integral, yang memasukkan berbagai sisi dan dimensi kemanusiaan secara utuh yaitu pengetahuan umum dengan pengetahuan agama yang berpedoman pada Al-Qur'an dan Al-Hadits. Dengan demikian pendidikan integratif yang diaplikasikan pada keluarga membentuk kualitas produk yang baik, sebagai modal awal penataan peradaban bangsa yang lebih baik di masa mendatang. Oleh karena itu, saat menghadapi berbagai perubahan sosial, budaya dan politik dalam masyarakat selalu mengacu pada konsep pendidikan Integratif ketauhidan.

Tingkat pencapaian pendidikan kebangsaan dalam lingkup keluarga ada tujuh sisi yang perlu dilakukan pada proses pendidikan integratif, yaitu pendidikan iman (agama), pendidikan moral, pendidikan fisik, pendidikan intelektual, pendidikan emosi (psikis), pendidikan sosial, dan pendidikan politik (Burbiel, 2009)

Konsistensi dalam menjalankan pendidikan kebangsaan dalam lingkup keluarga ada tujuh hal yang wajib diterapkan saat berlangsungnya pendidikan integratif menuju pada terbentuknya nilai-nilai kebangsaan, yaitu pendidikan agama (iman), pendidikan moral, pendidikan fisik (kesehatan), pendidikan intelektual, pendidikan emosi (psikis), pendidikan sosial, dan pendidikan politik.

\subsection{Pendidikan Agama dalam Pembentukan Nilai Kebangsaan}

Kemajuan capain pendidikan tauhid merupakan pondasi yang kokoh bagi seluruh bagian-bagian pendidikan karena pendidikan tauhid dapat membentuk kecerdasan spiritual. Pengetahuan dan pengamalan agama yang terbentuk dalam diri setiap anggota keluarga sebagai generasi, memungkinkan pengembangkan potensi fitrah sebagai pemimpin yang adil dan sosial sebagaimana gerakan pengajaran Cokroaminoto. Dimana dalam agama Islam pemimpin adalah bagian dari iman sehingga makna keimanan dalam diri Cokroaminoto yang didemonstrasikan dalam bentuk aksi, sebagaimana makna iman yang sebenarnya seperti keyakinan akan keberadaan Allah Yang Maha Esa, Allah Yang Maha Melihat perbuatan manusia, Allah Yang Maha Membalas perbuatan manusia, Allah Yang Maha Adil dalam memberikan hukuman dan 
pembalasan, Allah Yang Maha Mengetahui segala apa yang tampak dan tersembunyi (Burger, 1977).

Makna animisme keberadaan Allah Yang Maha Esa menjadi sebuah pedoman imunitas bagi seluruh Muslim dalam menjalankan kegiatan sehari-hari. Oleh karena itu, seorang individu mesti sadar aktivitas kesehariannya serta merasa diawasi oleh Tuhan Yang Maha Melihat. Dengan prinsip tersebut seorang pejabat melaksanakan sesuai amanah, tidak menyelewengkan wewenangnya walaupun terbuka kesempatan perihal yang menuju pada perilaku menyimpang, karena adanya keyakinan Tuhan Maha Tahu dan merasa diawasi oleh Tuhan. Inilah hakikat iman yang menjadi renungan bagi Cokroaminoto sebagai seorang pemimpin karena bagi beliau sangat fundamental bagi kehidupan sosial di dunia dan akhirat. Secara sederhana setiap orang wajib merasa dirinya dibawah pengawasan dan pemeliharaan Allah, inilah yang diistilahkan Cokroaminoto mengenai ketergantungan pada Allah.

Cokroaminoto menilai bahwa keimanan juga membentuk pemikiran dan sudut pandang tersendiri, yaitu manusia dalam melihat segala sesuatu berdasarkan perspektif ketuhanan. Sebagai umat yang beragama, seharusnya dituntut melihat segala hal dengan sudut pandang yang bertuhan. Pragmatisme dan perbuatan fatalistik semakin sering dilakukan oleh masyarakat dalam menghadapi kesusahan hidup, merupakan contoh pemikiran dan sudut pandang yang tidak memperhatikan nasionalisme dan sosialisme serta keberpalingan dari ajaran agama (Chaidar, 2013).

Konsep keagamaan harus dijadikan perhatian utama dalam membentuk imunitas keluarga dalam menghadapi gelombang globalisasi yang terus menyapu nilai-nilai kebangsaan anak-anak bangsa. Penanaman nilai-nilai kebangsaan dengan dasar keimanan bagi keluarga adalah bentuk pengamalan Pancasila khususnya sila pertama. Cokroaminoto menyampaikan, iman atau agama yang kokok melahirkan pula kepatuhan manusia terhadap hukum dan aturan serta solidaritas sosial karena itu tuntutan dan ajaran yang hadir dari Tuhan dan menjadi kewajiban manusia Muslim agar selalu mengamalkannya. Untuk kebaikan kehidupan manusia dan menjauhkan manusia dari kesalahan merupakan tujuan seluruh hukum dan aturan dari Tuhan yang diberikan kepada manusia. Pendidikan dalam keluarga mesti membiasakan dan berlatih untuk menuruti hukum dan aturan dari Tuhan, agar kehidupan yang terbangun berada sesuai dengan jalan yang benar (Chairil, 2013). 


\subsubsection{Pendidikan Moral Sebagai Wujud Nilai-Nilai Kebangsaan Berbasis Tauhid}

Moral menjadi bingkai kehidupan manusia setelah memiliki landasan kokoh berupa iman dan menjalankan syariat-syariat Islam. Pendidikan moral dalam proses degradasi moral dialami oleh masyarakat, maka moralitas perlu dikuatkan melalui pendidikan keluarga sehingga semakin signifikan manfaatnya. Pada hakekatnya moral merupakan tolak ukur nilai yang sudah diterima oleh suatu komunitas, berupa ajaran-ajaran atau nasihat, tolak ukur atau kumpulan peraturan secara lisan maupun tertulis terkait kehidupan manusia dan berperilaku supaya melahirkan manusia yang realistik, objektif dan rasional atas dasar bangsa serta community. Walaupun setiap agama mempunyai doktrin moral, setiap budaya masyarakat juga mempunyai ukuran nilai moral, yang jika diterapkan dapat mengakibatkan adanya kecerdasan moral setiap individu, keluarga maupun masyarakat dan bangsa (Chua, 2008).

Keluarga adalah sarana sekaligus objek dalam mengimplementasikan pendidikan moral dan kebangsaan yang dilandasi dengan ketauhidan, juga tak terbatas upaya prefentif terhadap timbulnya keburukan, akan tetapi harus melakukan eksplorasi yang maksimal terhadap potensi-potensi kebaikan dan ini harus dimunculkan secara equilibrium dalam keluarga agar lahir generasi yang bermoral. Oleh karena itu, contoh yang mesti dikedepankan berupa penanaman nilai kebiasaan yang benar dalam hubungan manusia dengan manusia yang lainnya, dan antara manusia dengan alam dan lingkungannya.

Pendidikan moral bagi generasi muda akan mengantarkan mereka menuju bangsa yang bermartabat, disegani, dan damai serta makmur dan sejahtera. Karena perilaku baik manusia tak hanya ditata dan dijalankan oleh faktor hukum, tetapi juga oleh faktor etika moral atau akhlak. Di sini dapat diartikan bahwa etika moral yang baik pada diri seseorang jauh lebih baik pada kestabilan sosial daripada mengandalkan hukum untuk kestabilan sosial. Konsep pendidikan keluarga mesti mengutamakan pendidikan agama yang mengakar pada nilai-nilai moralitas, etika, sikap sebagai perilaku dasar yang wajib dimiliki setiap individu secara holistik dengan aspek yang bernuansa membangun kesadaran pentingnya ilmu tauhid (Cokroaminoto, 1985).

\subsubsection{Pendidikan Emosi Dalam Pembentukan Nilai-Nilai Kebangsaan Berbasis Tauhid}


Konsep dan nilai pendidikan yang dibangun oleh Cokroaminoto yang terkait mengenai pendidikan emosi (psikis) antaranya membentuk banyaknya karakter kejiwaan yang positif, seperti keberanian, kejujuran, kemandirian, kelembutan, sikap optimistik, yang dibingkai pada penanaman nilai-nilai ketauhidan. Begitu fundamentalnya karakter tersebut karena menjadi dorongan bagi manusia melaksanakan hal-hal yang terbaik dalam urusan dunia dan akhiratnya. Salah satu paradigma Cokroaminoto tentang anggapan bahwa IQ (Intelligence/Intellectual Quotient) sebagai satu-satunya tolak ukur kecerdasan untuk mencapai keberhasilan dan kesuksesan suatu SDM, Sehingga dalam pernyataannya bahwa:

"Menjadi orang besar maka individu harus pintar menulis seperti wartawan dan berpidato seperti orator yang diintegrasikan pada nilai-nilai tauhid" (Cokroaminoto, 1995).

Pandangan Goleman tentang kecerdasan emosional merupakan kemampuan seseorang mengelola sifat emosinya dengan intelegensi, menjaga emosi dan cara mengungkapkannya secara selaras, melalui keterampilan kesadaran diri, pengendalian diri, motivasi diri, empati dan kreativitas sosial. Kecerdasan emosional memang sebaiknya ada pada semua individu karena sangat penting bagi semua ruang sosial sebagaimana pandangan Goleman tentang orang-orang yang hanya memiliki kecerdasan secara akademis yang tinggi, mereka lebih memiliki rasa gelisah yang tak memiliki alasan, terlalu kritis, cerewet, lebih menarik diri. Selain itu, mereka terkesan kaku dan lebih sulit mengungkapkan kekesalan dan kemarahannya secara benar. Di lain sisi individu dengan taraf kecerdasan emosional yang rendah, secara otomatis akan menjadi sumber masalah, karena cenderung akan terlihat sebagai orang berwatak keras, sulit bersosialisasi, mudah stress, sulit percaya kepada orang lain, tidak sensitif dengan kondisi lingkungan dan mudah putus asa bila mengalami stress (Erfan et la., 2014).

Persoalan tersebut secara substansi pendidikan emosional harus menjadi perhatian utama dalam dunia keluarga dan pendidikan agar setiap generasi memiliki nilai kepekaan terhadap bangsa dan masyarakat. Karena dengan kecerdasan emosional maka generasi bangsa selalu berpikir kepentingan golongan dan selalu kreatif, bijak, sosial, bertanggung jawab serta berwawasan yang luas. Konsep inilah yang diharapkan oleh Cokroaminoto dalam pendidikan kebangsaan untuk setiap generasi.

Kemampuan dan kecerdasan EQ (emotional quotient) dalam pandangan Cokroaminoto merujuk pada kemampuan beradaptasi di berbagai ruang-ruang 
sosial seperti organisasi yang dikenal dengan SDI dan SI dan berbagai pekerjaan lainnya. Kemampuan EQ (emotional quotient) sangat fundamental untuk dimiliki semua individu maupun pemimpin karena didalamnya terdapat potensi sosial yang sangat diperlukan dalam lembaga sosial, politik, pendidikan bahkan seluruh kehidupan sebagaimana pendapat Peter Salovey dan Mayer himpunan bagian dari kecerdasan sosial yang menyertakan kemampuan melihat perasaan sosial yang menyertakan kemampuan pada orang lain, memilih-milih seluruhnya dan memanfaatkan informasi ini agar mengarahkan pikiran dan tindakan (Fealy, 1998).

\subsection{Pendidikan Intelektual dalam Bingkai Ilmu Sebagai Pembentukan Nilai-Nilai Kebangsaan}

Pendidikan kebangsaan yang diwariskan Cokroaminoto tergambar pada keintelektualannya, hal tersebut tercermin pada sikap dan perilaku dalam menuntaskan banyaknya fenomena baik yang berkaitan pada aspek internal maupun pada aspek eksternal yaitu masalah pribadinya maupun persoalan bangsa dan kehidupan lain yang dihadapinya. Keintelektualan Cokroaminoto yang mampu memisahkan persoalan pribadi dengan kepentingan sosial menjadikan dirinya begitu berharga oleh banyak masyarakat. Selain itu, Cokroaminoto juga disegani karena secara pribadi beliau lebih mendahulukan kepentingan umat daripada kepentingan hidupnya sendiri sehingga Soekarno sebagai presiden pertama di Indonesia menggelar Cokroaminoto sebagai guru bangsa. Oleh karena itu, Cokroaminoto dalam melakukan transfer of neiges untuk murid-muridnya tentang berpikir harus menggunakan akal sehat dan budaya santun sebab itu merupakan ciri dari individu yang intelektual. Dengan begitu ranah intelektual wajib menjadi fokus dalam berlangsungnya pendidikan integratif dalam keluarga seperti penguatan pada aspek iman, moral, maupun emosional (Fend, 2002).

Karakter yang tergambar dalam diri Cokroaminoto dan terus mengalir pada jiwa setiap generasinya. Pendapat AS. Hornby, "intellectual is having or showing good reasoning power". Seseorang yang memiliki intelektual yang matang merupakan individu yang dapat menjalani seluruh persoalan secara logika yang baik karena lebih utama menggunakan pertimbangan-pertimbangan logis, sistematis, dan efisien. Selain itu, seseorang yang berintelektual dapat 
menciptakan ide-ide baru, mampu menghadapi kritikan orang lain, serta dhamir dalam gramatikal bahasa. Jadi, intelektual yang matang dapat dinilai dari sejauh mana seseorang memanfaatkan intelegensinya, tidak berdasarkan tingkat perkembangan mentalnya (Fisdaus, 2016).

Mencapai kematangan intelektual tersebut pondasi dasarnya harus bermula dari lingkup keluarga. Namun selain tugas keluarga bersama lingkungan yang kondusif juga yang sangat fundamentalnya adalah ruang lingkup pendidikan seperti pendidikan formal dan non formal di seluruh jenjang karena lembaga pendidikan merupakan wadah pematangan intelektual. Jika belajar dari negara Jerman, perguruan tinggi di Jerman menuntut calon mahasiswanya telah mencapai hochschulreife, artinya baik intelektual maupun emosional yang matang, agar dapat menjalani studi akademis.

\subsubsection{Pendidikan Sosial Ketahidan dalam Menatap Nilai-Nilai Kebangsaan}

Konsep pendidikan kebangsaan Cokroaminoto yang menjadi nilai pendidikan adalah aspek ketauhidan dan aspek kesosialan. Nilai sosial yang tertanam dalam kepribadiannya tercermin dari kemampuannya bersosialisasi dan memberikan kontribusi positif bagi upaya perbaikan masyarakat. Kesadaran fundamental pendidikan sosial sebab dapat memunculkan solidaritas sosial yang pada saatnya memaksimalkan peran sosial baik dalam anggota keluarga maupun pada masyarakat. Pendidikan bagi keluarga bertujuan kepada matangnya intelektual, supaya anggota keluarga mempunyai persiapan dalam menghadapi segala kondisi kehidupan dengan nalar yang matang dan sehat. Jadi secara konseptual, intelektual yang matang bisa dibentuk dengan menggunakan teknik pembelajaran yang sesuai agar pembelajaran mamput terintegrasi dengan baik (Formichi, 2010).

Tujuan dari pendidikan kebangsaan adalah untuk membina wawasan kebangsaan warga negara. Wawasan kebangsaan dapat diperoleh melalui pembelajaran di sekolah seperti pelajaran PPKn, sejarah, seni budaya, dan kegiatan Gerakan Pramuka. Namun, akhir-akhir ini minat pelajar untuk mempelajari pelajaran-pelajaran tersebut semakin menurun karena tidak dianggap 'kekinian'. Contohnya, murid lebih senang akrab dengan biografi para artis ternama dunia daripada sejarah para pahlawan nasional. Nilai kebangsaan memiliki peranan yang sangat penting dalam membentuk nasionalisme dan patriotisme suatu bangsa. Pada masa penjajahan, nilai kebangsaan lebih mudah 
ditanamkan karena rasa cinta terhadap Tanah Air yang dihadapkan pada tantangan nyata. Para pejuang kemerdekaan rela mempertaruhkan nyawa demi membebaskan Indonesia dari cengkeraman penjajah. Namun, di era globalisasi, nilai kebangsaan semakin memudar. Hal itu dipengaruhi antara lain oleh pesatnya perkembangan teknologi dan pada saat bersamaan, menguatnya fundamentalisme agama. Sikap kebangsaan perlu ditanam dalam diri para murid sejak usia dini melalui pendidikan kebangsaan. Pendidikan kebangsaan adalah suatu sistem belajar yang berkaitan dengan penguatan nasionalisme (Kirom, et al., 2012).

Lingkungan keluarga mesti menghadirkan pendidikan sosial yang sesuai kepada seluruh anggota keluarganya, dengan tujuan agar memiliki rasa sosial yang menjadikan setiap anggota keluarga dapat berinteraksi dengan positif pada lingkungan masyarakat serta lingkungan pergaulannya. Kecerdasan intelektual merupakan hal utama yang perlu dikembangkan bagi setiap individu, namun kecerdasan sosial merupakan kecerdasan yang sangat pentingnya bagi setiap orang. Ini artinya bahwa kecerdasan intelektual memiliki hubungan sinerji wajib ada pada semua individu dalam masyarakat karena dengan dua potensi tersebut lebih memudahkan membangun ruang interaksi dalam mencapai suatu kestabilan sosial. Tak dipungkiri bahwa majunya suatu ilmu pengetahuan dan teknologi telah dehumanisasi, karena interaksi sosial telah diminimalisir dimana interaksi sosial terhadap teman, tetangga, saudara, juga anggota keluarga sendiri semuanya serba menggunakan teknologi.

\subsubsection{Pendidikan Politik dalam Nilai-Nilai Kebangsaan}

Keluarga merupakan unsur penting untuk mendapatkan perhatian karena konsep ketaatan yang ditanamkan dalam diri anak akan menjadi nilai positif untuk pengabdian kepada kepentingan bangsa. Pendidikan politik perlu ditanamkan dalam keluarga, karena pendidikan politik juga berperan dalam pembentukan sikap cinta dan belah tanah air. Pendidikan politik telah menjadi bagian dari konsep kebangsaan yang dimulai secara bersamaan diperkenalkan oleh adanya pandangan dari Plato dan Aristoteles yang berasumsi bahwa adanya kemiripan antara pendidikan anak-anak dengan tabiat negara. Sejalan dengan pendapat Boden, dalam tulisan-tulisannya yang mengemukakan bahwa urgensi kepatuhan dalam lembaga keluarga adalah dasar ketaatan terhadap institusi pemerintah dan pengabdian kepada bangsa serta masyarakat. Pendapat tersebut menunjukkan kesesuaian dengan karakter Cokroaminoto dengan gerakan 
politik sosial yang dibangunnya membuat masyarakat menjadi terkagumkagum, sampai-sampai Cokroaminoto dijuluki sebagai tokoh sosialisme Islam (Kirom et al., 2013).

Nilai pendidikan politik yang paling utama untuk keluarga ialah pengaplikasian dengan memberikan contoh seperti hierarki kekuasaan yang positif yang berada pada lembaga keluarga, memberikan sistem kekeluargaan yang tidak membedabedakan, dan selalu memberikan bahasa yang santun, konsep yang menuju pada kemaslahatan ummat serta simbol-simbol kepentingan bangsa. Praktik pendidikan politik dalam organisasi keluarga dapat tercipta dengan baik dan benar bilamana didukung dengan sistem dan mekanisme yang bersandar pada nilai-nilai Al-Qur'an dan Al-Hadits. Ruang lingkup keluarga, hierarki kekuasaan merupakan metode pendidikan politik, karena organisasi keluarga merupakan negara minim bagi anak-anak. Sebagaimana pendapat Dean Jaros dalam bukunya Socialization to Politics, pengetahuan anak-anak mengenai kekuasaan yang berada pada organisasi keluarga merupakan awal pengetahuannya terhadap memanejemen dan membangun kekuasaan bagi negara dan kedudukannya di dalam Negara (Kohar, 2012).

Melalui konsep pendidikan politik dalam keluarga, maka keluarga dapat melahirkan generasi berjiwa sosial dan berperilaku sosial serta politisi yang bermoral. Pencapaian pendidikan politik dalam keluarga tak terlepas dari suasana keluarga. Karena suasana keluarga merupakan akar utama tercapainya pendidikan politik maka diperlukan mendidik dengan cinta, kasih sayang dan kemesraan hubungan terhadap anak-anak. Sehubungan dengan penanaman nilai simbol-simbol politik tidak sekedar simbol-simbol saja, tetapi juga lebih mengarah pada pendidikan kekuasaan dan negara yang mengutamakan kepentingan masyarakat dan bangsa dengan penguatan pada semua simbol budaya yang memiliki muatan makna politik. Salah satu simbol yang memiliki nilai pendidikan politik yang banyak sekali dijumpai dalam ruang lingkup keluarga terdapat pada tokoh Cokroaminoto. Simbol ini bisa menjadi tokoh sentral dalam menanamkan nilai-nilai pendidikan kepada anak-anak sebagai generasi mendatang (Kees, 1995).

Paparan tersebut dapat disimpulkan bahwa pendidikan bagi keluarga sebagai akar utama sebagai pondasi dasar pembentukan nilai-nilai kebangsaan karena selain menjadi pendidikan awal bagi anak juga sebagai ruang adaptasi untuk mengenal sesuatu hal. Sehingga orang tua saat membentuk pengalaman anakanaknya lebih mengutamakan pada konsep keteladanan orang tua dalam perilaku sehari-hari, pendidikan moral, menjadikan anak sebagai makhluk yang 
sosial, religius, untuk menghadirkan keadaan yang bisa menumbuhkembangkan inisiatif dan kreativitas.

\subsection{Pendidikan Kebangsaan dalam Memper- kuat Jejaring Sosial}

Karakter kebangsaan Cokroaminoto yang mesti diteladani adalah jiwa solidaritas, kesetiaan terhadap bangsa, keberanian terhadap yang benar, non sukuisme dan konsep persamaan hak yang diperjuangkan. Melalui karakter tersebut, nilai manfaat yang dihasilkan Cokroaminoto dalam gerakan sosial. Cokroaminoto lebih mudah membuka jejaring sosial atau social networking dalam bentuk ikatan-ikatan sosial baik pada tingkatan individu atau kelompok serta kegiatan lain yang terkait Pembangunan nilai-nilai pendidikan kebangsaan bagi semua anak bangsa merupakan suatu kewajiban karena pendidikan kebangsaan memiliki manfaat pada kehidupan sosial dan bangsa itu sendiri. Manfaat dari pemahaman nilai pendidikan kebangsaan dapat dilihat pada karakter Cokroaminoto seperti komitmen jiwa dalam meretas kekuatan penjajah yang ingin menguasai tanah air Indonesia. Selain itu (Jujun, 2005)

Peran jejaring sosial Cokroaminoto secara realitas sosial, mempunyai banyak tingkatan, diawali dari tingkatan individu dalam keluarga, masyarakat, sampai pada tingkatan negara atau internasional. Dari jejaring sosial tersebut telah menjadi jalan bagi Cokroaminoto untuk memperkuat hubungan solidaritas dengan menyertakan banyak pihak dan pola hubungan baik horizontal maupun vertikal sebagaimana dalam organisasi SDI dan SI.

Peningkatan jejaring sosial ke semua lapisan sosial tanpa membedakan status sosial dapat dilakukan oleh Cokroaminoto dengan strategi pemberdayaan semua kelompok-kelompok sosial masyarakat di berbagai unsur dan tingkatan struktur, unsur tersebut diantaranya kaum petani, pengusaha, agamais yang mulai dari strata sosial yang dibawa, menengan sampai pada level yang lebih kaya dan pemegang kekuasaan. Jejaring sosial Cokroaminoto terbangun begitu cepat melalui organisasi SI karena menggunakan hubungan relasional yang khas (spesifik). Kekhasan ini, seperti kemampuan intelektual yang didukung dengan keberanian, tanggung jawab konsep-konsep perlawanan terhadap kaum penindas sehingga masyarakat bersedia menyatu dalam kubu Cokroaminoto. Pembentukan jejaring sosial dalam lingkaran Cokroaminoto disebabkan karena 
adanya kesamaan seperti nilai, visi, misi, tujuan, pekerjaan dan sebagainya (Rugani, 2020)

Desain jejaring sosial Cokroaminoto masuk pada model jejaring sosial berhubungan dengan bentuk koneksitas yang lebih bersifat longgar, terbuka dan plural. Koneksitas seperti ini dapat terwujud dalam jaringan sosial yang sifatnya heterogen. Contoh yang diambil Putnam adalah kelompok paduan suara dan klub bowling. Sebagaimana pendapat Bourdieu, (1986) kapital sosial sebagai akumulasi sumberdaya aktual atau potensial yang memiliki kaitan terhadap penguasaan jaringan yang dapat bertahan lama atau setidak-tidaknya pelembagaan hubungan perkenalan dan pemberian penghargaan yang saling menguntungkan. Sebagaimana pendapat Bourdieu dan Dwyer et.al, bahwa setiap jaringan sosial memiliki daya untuk memproduksi kekuatan (power) dan keragaman. Keragaman (inequality) yang terproduksi pada suatu hubungan sosial memiliki nilai tambah yang memberikan keuntungan dalam pembagian kerja.

Investasi sosial dapat berupa aktif dalam organisasi-organisasi sosial; memberi penghargaan, bantuan atau empati pada rekan; memperluas jaringan sosial dengan membuat perkenalan dan pertemanan baru atau suasana (tempat) baru. Gagasan tentang kapital sosial didasarkan atas sebuah premis mayor bahwa manusia merupakan makhluk sosial memiliki naluri alamiah untuk mengikat hubungan emosional atau persaudaraan. Sebagaimana pandangan Pierre Bourdieu dan Lin bahwa memiliki cadangan sumber daya (embedded resources) sosial pasti ada pada setiap komunitas atau kelompok sosial. Individu yang mampu mencari, mengumpulkan dan menggunakan sumber daya sosial yang mampu menikmati kapital sosial. Oleh karena itu, Lin menganjurkan, untuk memperbanyak atau memperkaya kapital sosial, individu harus membuat banyak investasi pada jaringan-jaringan sosial (Jalaluddin, 1997).

Disimpulkan bahwa sosial kapital harus terus dijaga dan dipertahankan keberadaannya karena mempunyai banyak manfaat bagi masyarakat, pemerintah, individu dan komunitas. Untuk memperkuat kapital sosial, masyarakat harus didorong menumbuhkan (to create) organisasi-organisasi sosial berkarakter kebangsaan. Kapital sosial diakui mempunyai pengaruh yang besar mulai dari peningkatan perekonomian dan penanggulangan kemiskinan serta fenomena sosial yang berkaitan dengan bangsa ini. 


\subsubsection{Pendidikan Kebangsaan Membentuk Kesadaran Sosial}

Penguatan nilai-nilai kebangsaan mengantar masyarakat pada kekuatan yang sangat besar dan kepedulian akan sesama dan sebangsa. Melalui penguatan nilai kebangsaan secara otomatis kekhawatiran terhadap sistem kehidupan dan pertahanan keamanan lebih berkurang. Selain itu, kematangan masyarakat dalam wawasan kebangsaan dapat mengurangi terjadinya disorientasi dan perpecahan. Dengan demikian, pemantapan nilai-nilai kebangsaan harus dikampanyekan secara kontinu di semua sektor pendidikan baik formal maupun non formal dan dilingkungan keluarga, agar masyarakat mempunyai status sosial yang jelas dan tujuan pembangunan tetap terarah pada perbaikan bangsa.

Rasa percaya diri yang krisis sebagai bangsa bisa berupa "keraguan" tentang kemampuan diri sebagai bangsa dalam menghadapi berbagai persoalan yang mendasar yang selalu mendera bangsa dan negara ini. Pendidikan kebangsaan lahir dari Cokroaminoto karena suatu keprihatinan terhadap masyarakat sosial dan fenomena sosial bangsa ini. Lemahnya nilai kebangsaan selain berdampak pada kesadaran sosial juga memiliki dampak kepada krisis multidimensional yang ditandai adanya krisis kepercayaan diri (self-confidence) dan rasa hormat diri (self-esteem) sebagai bangsa. Selain dari keprihatinan dari berbagai kalangan masyarakat yang mampu disadari oleh Cokroaminoto juga disebabkan karena dinamika perkembangan politik, sosial, ekonomi dan budaya dimana hak-hak masyarakat semakin terkucilkan serta marginalisasi yang semakin meningkat. Oleh karena itu, Cokroaminoto memperkuat penanaman nilai-nilai kebangsaan melalui konsep agama dan budaya sebagai langkah membangun kesadaran sosial masyarakat sebagai generasi bangsa saat bertarung dengan kaum penjajah yang ingin monopoli (Amin, 1980).

Bangsa dapat saja berada dalam bahaya apabila terjadi krisis identitas sosial masyarakat sebagai generasi bangsa telah berefek pada krisis politik dan krisis ekonomi telah membias sampai pada krisis kepercayaan diri, sehingga nilai moral bangsa dalam eksistensinya, dan Indonesia sebagai bangsa yang sedang dipertaruhkan. Maka, saat ini merupakan waktu yang tepat untuk membuat reevaluasi pada proses terciptanya "nation and character building", karena bisa saja berbagai persoalan yang kita alami saat ini dimulai dari kesalahan dalam menghayati dan mengaplikasikan konsep awal "kebangsaan" sebagai pondasi keIndonesiaan. Kesalahan inilah yang bisa menjatuhkan Indonesia, seperti yang dikhawatirkan Cokroaminoto dan Soekarno," "menjadi bangsa kuli dan kuli diantara bangsa-bangsa. 
Kemajemukan atau keberagaman mesti menjadi kesadaran bersama dan dapat dijadikan magnet yang membuat semakin kokohnya bangsa dengan membuang berbagai bentuk pandangan yang berbeda dapat menyebabkan konflik. Persatuan bangsa menjadi kuat pada saat semua merasa mempunyai kesamaan dalam kepentingan dan tujuan, yaitu menciptakan masyarakat Indonesia yang sejahtera adil dan makmur sesuai dengan Pancasila dan UUD 1945 (Legge, 2000). Kesatuan adalah kepekaan yakni menjadikan kemajemukan itu menjadi satu yang total yaitu Indonesia. Memperkuat persatuan bangsa adalah satu proses memadukan segala cipta, rasa, dan karsa, menuju keekaan tanpa sekat, dan menciptakan Negara Kesatuan Republik Indonesia (NKRI) sebagai sesuatu yang final, yang menjadi kewajiban bagi warga negara Indonesia dalam melindungi seluruh wilayah Indonesia dari hambatan, gangguan, tantangan, serta ancaman yang muncul dari dalam dan luar negeri.

Hakikat Identitas nasional atau jati diri suatu bangsa yaitu penjelasan tentang tumbuh dan berkembangnya nilai-nilai budaya di dalam aspek kehidupan suatu bangsa yang diimplementasikan pada kepentingan tanah tumpah darah mereka sendiri. Mendalami dan mengetahui mengenai identitas bangsa secara substansial harus selalu menjunjung nilai-nilai kebangsaan, sekaligus menimbulkan rasa kebangsaan, dan semangat kebangsaan yang sangat dibutuhkan untuk membentuk serta memperkokoh persatuan dan kesatuan bangsa (Laning, 2008)

\subsubsection{Pendidikan Kebangsaan Memperjelas Identitas Nasional}

Menggali dan menemukan kembali identitas nasional suatu bangsa dalam konsep Cokroaminoto sangat erat dengan pendekatan pemahaman nilai-nilai kebangsaan. Krisis nilai-nilai kebangsaan dapat berdampak pada nilai kejujuran, nilai keterbukaan, berani mengambil resiko, bertanggung jawab atas perbuatannya, dan berbagi terhadap sesama. Oleh karena itu, penanaman nilainilai identitas sebagai karakter bangsa wajib diimplementasikan dalam berbagai kehidupan yang dimulai pada diri sendiri, generasi dan pembangunan karakter pada masyarakat untuk ketahanan negara. Nilai identitas inilah yang dibentuk oleh Cokroaminoto pada berbagai aspek kehidupan, dan prinsip tersebut telah ditransfer ke semua murid-muridnya sehingga mendapat julukan sebagai guru bangsa dari salah seorang muridnya yang bernama Soekarno Presiden pertama Indonesia. 
Identitas Cokroaminoto tercermin pada ciri-ciri karakter yang ditampilkan seperti jiwa sosial, keberanian dan cinta tanah air yang telah menjadi ciri khas yang ada pada kepribadiannya. Identitas nasional Cokroaminoto yang tak usah diragukan dan harus menjadi gambaran bagi semua generasi adalah mengembangkan kembali jiwa Cokroaminoto yang selalu berorientasi pada kesatuan komunitas sosio-kultural serta memiliki semangat, cita-cita, tujuan, dan ideologi bersama (Kurniawan, 2011).

Pencapaian identitas nasional memerlukan sikap patriotisme, terwujudnya sikap patriotisme bilamana setiap generasi mampu mengutamakan kepentingan bangsa dan negara diatas kepentingan pribadi atau golongan, menjalin persatuan dan kesatuan bangsannya, memelihara nama baik bangsa dan negara di mata dunia, berani minta maaf dan memaafkan, bersungguh-sungguh saat belajar dan senantiasa melestarikan budaya serta menghargai perbedaan. Mempertahankan identitas nasional memerlukan jiwa patriotisme sebagaimana jiwa Cokroaminoto yang senantiasa bertindak dengan prinsip rela berkorban dalam membela bangsanya melalui profesinya. Hal tersebut terlihat pada masa Cokroaminoto masuk dalam organisasi Sarekat Dagang Islam (SDI) dimana Cokroaminoto lebih mengedepankan keberpihakan kepada pribumi sebab kaum pribumi sangat dikucilkan. Selain itu, identitas nasional Cokroaminoto juga tercermin pada saat ikut serta dalam organisasi jurnalistik (wartawan), berbagai kritik dan ide-idenya terus dituangkan melalui tulisan-tulisannya. Gagasan Cokroaminoto yang paling fundamental dan sangat vital mengenai konsep pembentukan bangsa Indonesia menjadi suatu Negara.

Kondisi geografis-ekologis yang menjadikan bangsa sebagai daerah kepulauan yang memiliki iklim tropis dan sebagai persimpangan jalan komunikasi antar wilayah dunia di Asia Tenggara turut berperan dalam perkembangan kehidupan demografis, ekonomis, sosial, dan kultural bangsa Indonesia. Selain itu, Indonesia memiliki faktor historis yang ikut mempengaruhi berlangsungnya penciptaan masyarakat dan bangsa Indonesia dengan identitas nya, melalui interaksi dari banyak faktor yang ada didalamnya, hasil interaksi tersebut menciptakan proses terbentuknya masyarakat, bangsa, dan negara beserta identitas bangsa ini. Faktor pendukung lahirnya identitas nasional suatu bangsa tidak terlepas dari dukungan faktor objektif, yaitu faktor-faktor yang memiliki korelasi dengan geografis-ekologis, demografis, dan faktor subjektif, yaitu faktor-faktor historis, organisasi politik, sosial, dan kebudayaan pada suatu bangsa tersebut (Rugani, 2020). 
Sisi lain, identitas bangsa dapat menjadi bumerang bagi nasionalisme jika nilainilai yang salah atau terlalu berlebihan menjadi paradigma setiap masyarakat dan generasi. Oleh karena itu, paham seperti sekularisme, individualisme, materialisme, ekstremisme, konsumerisme, dan diskriminatif mesti dilakukan langkah preventif agar paham tersebut tidak menjadi virus dalam kehidupan sosial bangsa dari tiap generasi. Paham tersebut sebagaimana pandangan Cokroaminoto merusak bangsa dan Negara karena sudah jauh dari konsep kebersamaan, kepentingan golongan, bangsa dan Negara serta berdampak pada rusaknya sikap nilai-nilai kebangsaan. Fenomena tersebut sangat penting untuk disadari oleh setiap anak bangsa karena hal tersebut telah menjadi dasar kehidupan dalam semua ruang lingkup sosial (Kohar, 2012). 


\section{Bab V}

\section{Manusia dan Perkembangan Ilmu Pengetahuan}

\subsection{Hakikat Ilmu Pengetahuan}

Manusia memiliki proses kognitif yang berguna untuk mendapatkan suatu pengetahuan dan suatu ilmu. Dapat kita ketahui bahwa ilmu dan pengetahuan memiliki perbedaan yang mendasar. Menurut Jujun (1007) mengatakan bahwa ilmu merupakan pengetahuan yang kita gumuli sejak bangku sekolah dasar sampai pendidikan lanjut dan perguruan tinggi. Dapat kita fahami bahwa ilmu merukapan suatu sekelompok pengetahuan yang kita dapatkan dari proses kognitif sejak menempuh jenjang pendidikan dasar, pendidikan menengah dan pendidikan tinggi. Seseorang yang melakukan proses kognitif dengan memperoleh sekelompok pengetahuan dari setiap jenjang pendidikan disebut peserta didik.

Ilmu merupakan suatu pemahaman yang telah diketahui oleh banyak orang lain, tidak hanya sebatas sekelompok orang saja. Ilmu bersifat obyektif yang berati apabila suatu kebenaran akan disetujui oleh banyak orang. Ilmu merupakan 
sekumpulan dari beberapa pengetahuan yang diuji kebenarannya. Suatu kebenaran dalam ilmu sudah teruji dan terukur valid dengan melakukan suatu penelitian. Ilmu dapat di jelaskan kembali sebab akibat dan yang lainnya dengan jelas dan benar. Terdapat empat macam kriteria ilmu yaitu, deskripsi, explain (menjelaskan), prediksi, dan kontrol (Jennie, 2017)

Deskripsi merukapan suatu gambaran mengenai suatu ilmu tersebut. misalnya ketika mengetahui bahwa seseorang sedang menangis maka kita dapat mendeskripsikan bahwa orang yang menangis tersebut mengeluarkan air mata. Explain (menjelaskan) merupakan penjelasan dari suatu pengetahuan. Misalnya apabila mengetahui orang yang menangis dan keluar air mata karena patah hati dan kecewa. Maka kita dapat menjelaskan sebab orang tesebut menangis dan keluar airmata. Prediksi, memprediksi atau melakukan dugaan terhadap sesuatu yang akan terjadi pada suatu pengetahuan. Mislanya ketika melihat orang ini bersedih maka dapat mempresiksi dia akan menangis dan mengeluarkan airmata. Prediksi dapat terjadi apabila ia sering menemukan kejadian yang sama (Jejen, 2011).

Kontrol, melakukan suatu intervensi atau penanganan dan tindakan dalam menghadapi suatu peristiwa. Misalnya bagaimana cara kita untuk memberikan penanganan atau intervensi ketika melihat seseorang yan menangis? Tentu saja dengan memberikan ketenangan, membuat dia nyaman dan melakukan konseling sederhana bila perlu. Apabila dari keempat kriteria ilmu tidak ada satupun yang terikat maka tidak dapat dikatakan sebagai suatu ilmu.

Menurut Liang (1010) ilmu atau science memiliki makna ganda yang mengandung lebih dari satu arti. Ilmu merupakan sebuah istilah umum untuk menyebut segenap pengetahuan ilmiah yang dipandang sebagai satu kebulatan yang disebut dengan science in general. Ilmu sebagai pengetahuan yang sistematis mengenai dunia fisis/ material seperti, biologi, geografi, sosiologi pengertian ini disebut juga dengan systematic knowledge of the physical or matherial world. Ilmu merupakan suatu kumpulan yang sistematis dari pengetahuan yang disebut dengan any systematic of knowledge. Ilmu juga disebut dengan suatu pengetahuan yang dihimpun dengan perantaraan metode ilmiah. Dari beberapa pnjelasan mengenai makna dari ilmu menurut Liang (Imron, 2012).

Terdapat makna lain diantaranya pengertian ilmu sebagai pengetahuan, aktivitas dan metode yang saling berkaitan.ilmu diusahakan dengan adanya aktivitas manusia, aktivitas harus dilaksanakan dengan adanya metode, sehingga aktivitas metode itu mendatangkan pengetahuan yang sistematis. Sedangkan 
pengetahuan merupakan sesuatu stimulus yang ditangkap oleh alat indera sehingga mendapatkan hasil sebuah pengetahuan. Kebenaran pengetahuan hanya dapat diketahui oleh beberapa orang saja. Pengetahuan bersifat subjektif. Pengetahuan tidak dilakukan uji atau penelitian guna membuktikan suatu kebenaran tersebut. pengetahuan merupakan suatu bentuk pengalaman yang dilakukan oleh orang lain (Jujun, 2003).

Pengetahuan terjadi apabila manusia dengan segenap kemampuan kemanusiaannya seperti perasaan, pikiran, pengalaman, pancaindra dan intuisi mampu menangkap alam kehidupannya dan mengabstraksikan tangkapan tersebut. Terdapat 3 kritesia pengetahuan, yaitu objek ontologis, landasan epistimologis, dan landasan aksiologis. pada kriteria objek ontologis menjelaskan mengenai objek yang ditelaah dapat menghasilkan sebuah pengetahuan. pengalaman manusia yang diperoleh dari alat indera. Kriteria landasan epistimologis menjelaskan mengenai cara yang dipakai untuk mendapatkan suatu pengetahuan (knowledge). Metode ilmiah yang berupa beberapa gabungan logika deduktif dan logika induktifdengan pengajuan hipotesis ilmiah yang juga melibatkan proses berpikir manusia (Mahyudin, 2013)

Kriteria yang ketika yaitu landasan aksiologis menjelaskan apa bentuk kontribusi atau kegunaan pada suatu pengetahuan. dapat dikatakan bahwa pengetahuan manusia dapat diwujudkan sebagai moral yang ditunjukkan untuk kebaikan hidup manusia. Dari penjelasan diatas dapat kita ketahui perbedaan antara ilmu dan pengetahuan bahwa ilmu merupakan sekelompok pengetahuan yang dapat diuji kebenarannya dan bersifat obejtif, sedangkan pengetahuan merupakan suatu stimulus yang ditangkan oleh alat indera dan diproses sehingga menghasilkan suatu pengetahuan yang bersifat subjektif.

\subsection{Pengelompokan Pengetahuan}

Sebuah kategori penggolongan jenis ilmu yang banyak dikemukakan oleh para ahli adalah pembedaan segenap pengetahuan ilmiah dalam dua kelas yang istilahnya saling berlawanan. Hal ini tampak sederhana sehingga mudah dipahami, tetapi pada umumnya tidak merincikan berbagai cabang ilmu, hanya biasanya diberikan contoh ilmu apa yang termasuk dalam masing-masing kelompok. Penggolongan ilmu sebagaimana dikutip dari Surajiyo (1008) sebagai berikut: 
a. Ilmu Formal dan Ilmu Nonformal

Suatu ilmu disebut Ilmu Formal karena ilmu ini dalam seluruh kegiatannya tidak bermaksud menyelidiki data-data inderawi yang konkret. Misalnya matematika dan filsafat. Suatu ilmu disebut Ilmu Nonformal karena di dalam ilmu ini pengalaman inderawi memainkan peranan sentral/utama. Ilmu ini dalam seluruh kegiatannya berusaha menyelidiki secara sistematis data-data inderawi yang konkret. Misalnya ilmu hayat, ilmu alam, dan ilmu manusia.

b. Ilmu Murni dan Ilmu Terapan

Ilmu Murni adalah ilmu yang bertujuan meraih kebenaran demi kebenaran (teoretis). Misalnya matematika dan metafisika. Ilmu Terapan adalah ilmu yang bertujuan untuk diaplikasikan atau diambil manfaatnya (praktis). Misalnya ilmu kedokteran, teknik, hukum, ekonomi, psikologi, sosiologi, administrasi, dan ekologi.

c. llmu Nomotetis dan Ilmu Idiografis

Ilmu Nomotetis adalah ilmu yang objek pembahasannya merupakan gejala pengalaman yang dapat diulangi terus-menerus dan hanya merupakan kasus-kasus yang mempunyai hubungan dengan suatu hukum alam. Termasuk dalam ilmu ini adalah ilmuilmu alam, yang objek pembahasannya adalah benda alam atau gejala alam, yang didekati dengan cara menerangkan. Ilmu Idiografis adalah ilmu yang objek pembahasannya merupakan objek yang bersifat individual, unik, yang hanya terjadi satu kali dan mencoba mengerti atau memahami objeknya menurut keunikannya itu. Termasuk dalam ilmu ini adalah ilmu-ilmu budaya, yang objek pembahasannya adalah produk manusia, yang didekati dengan cara mengerti atau memahami.

\section{d. Ilmu Deduktif dan Ilmu Induktif}

Suatu ilmu disebut Ilmu Deduktif karena semua pemecahan yang dihadapi dalam ilmu ini tidak didasarkan atas pengalaman indrawi (empiris), melainkan atas dasar deduksi atau penjabaran. Deduksi 
adalah proses pemikiran yang melibatkan akal budi manusia dari pengetahuan tentang hal-hal yang umum dan abstrak, menyimpulkan tentang hal-hal yang bersifat khusus dan individual. Misalnya matematika. Suatu ilmu disebut Ilmu Induktif apabila penyelesaian masalah-masalah dalam ilmu yang bersangkutan didasarkan atas pengalaman indrawi (empiris). Ilmu Induktif bekerja selalu atas dasar induksi, yaitu proses pemikiran yang melibatkan akal budi manusia dari pengetahuan tentang halhal yang bersifat khusus dan individual, menarik kesimpulan tentang hal-hal yang bersifat umum dan abstrak. Misalnya ilmu alam (Salam, 2003).

Van Melsen membedakan ilmu pengetahuan menjadi ilmu-ilmu empiris (ilmu alam, ilmu sejarah, ilmu-ilmu manusia) dan ilmu-ilmu non-empiris (matematika dan filsafat):

a. Ilmu alam

Ilmu alam ini melukiskan kenyataan menurut aspek-aspek yang dapat di inderawi secara langsung. Data inderawi ini harus dimengerti sebagaimana nampaknya. Hal ini dapat dilakukan melalui observasi ilmiah yang memiliki objektivitas pada objek. Ilmu alam menyelidiki kenyataan konkret menurut aspek-aspeknya yang dapat diulangi.

b. Ilmu sejarah

Ilmu sejarah yang dimaksud adalah ilmu yang menyangkut sejarah manusia. Ilmu sejarah ini menyelidiki segala sesuatu yang berhubungan dengan tindakan manusiawi, yang dapat juga diungkapkan melalui peninggalanpeninggalan fisis. Karena sejarah meliputi semua kejadian yang pernah berlangsung, akibatnya ilmu sejarah ini tidak bisa mengadakan eksperimen.

c. Ilmu - ilmu manusia

Ilmu ini juga disebut ilmu-ilmu tingkah laku (behavioral science) atau ilmuilmu sosial. Ilmu-ilmu manusia ini diberi tempat tersendiri di samping ilmu sejarah dan ilmu alam, karena ilmu sejarah maupun ilmu manusia menyangkut perbuatan serta tingkah laku manusia. Di samping itu, ilmu manusia juga mempunyai persamaan dengan ilmu alam, dengan usahanya untuk menemukan secara khusus aspek-aspek yang dapat diulangi (Surajiyo, 2006). 


\section{d. Matematika}

Matematika merupakan ilmu non-empiris dan dalam bentuk abstrak yang juga mempunyai peranan penting dan dapat diterapkan bagi ilmu-ilmu empiris. Karena keabstrakan matematika ini, ia menyediakan berbagai struktur formal bagi ilmu-ilmu lain.

e. Filsafat

Filsafat juga merupakan ilmu non-empiris, yang berfungsi sebagai kerangka sistematis yang umum, mengingat adanya pandangan bahwa filsafat sebagai induk semua ilmu lain. Dalam keanekaragaman ilmu ini perlu diteruskan pencarian jawaban atas pertanyaan yang pada awal mulanya dikemukakan oleh filsafat (Wahidin, 2009)

\subsection{Pengetahuan Ilmiah}

Dalam penjelasan tentang pengetahuan Jujun S. Suriasumantri mengemukakan bahwa kumpulan pengetahuan yang disusun secara konsisten dan kebenarannya telah teruji secara empiris itulah yang disebut dengan ilmu atau bisa dikatakan ilmu pengetahuan. Ciri-ciri pengetahuan yang bersifat ilmiah :

1. Mempunyai derajat kepastian yang tinggi, dimanah pijakan berpikirnya dilandasi pengetahuan yang luas.

2. Mempunyai alur berpikir yang sistematis dan sistemik

3. Memiliki kadar kebenaran yang luas dan disepakati bersama, sehingga pengetahuan ilmiah mempunyai metode ilmiah yang sama. (Wahidin, 1009).

Landasan Pengetahuan Ilmiah. Setiap jenis pengetahuan mempunyai ciri-ciri yang spesifik mengenai apa (ontologi), bagaimana (epistemologi), dan untuk apa (aksiologi) pengetahuan tersebut disusun. (Jujun S. Suriasumantri,1990). Ke tiga landasan ini saling berkaitan. Jadi ontologi ilmu terkait dengan epistemologi ilmu dan epistemologi ilmu terkait dengan aksiologi ilmu dst. Jadi kalau kita ingin membicarakan epistemologi ilmu, maka hal ini harus dikaitkan dengan ontologi dan aksiologi ilmu (Van, 2010).

Ilmu mempelajari alam sebagaimana adanya dan terbatas pada lingkup pengalaman kita. Pengetahuan dikumpulkan oleh ilmu dengan tujuan untuk 
menjawab permasalahan kehidupan yang sehari-hari dihadapi manusia dan digunakan untuk menawarkan kemudahan. Pengetahuan ilmiah merupakan sebagai alat bagi manusia dalam memecahkan berbagai persoalan yang dihadapinya. Pemecahan tersebut pada dasarnya adalah dengan meramalkan dan mengontrol gejala alam. Dengan ilmu manusia memanipulasi dan menguasai alam. Dengan mempelajari alam manusia dapat mengembangkan pengetahuan. Pengetahuan berkembang melalui pengalaman dan rasionalisme yang didukung oleh metode mencoba-coba/trial-and error .(Jujun S. Suriasumantri, Hal : 105-106) (Surajiyo, 2008).

Ilmu atau ilmu pengetahuan juga memiliki definisi sebagai seluruh usaha sadar untuk menyelidiki, menemukan, dan meningkatkan pemahaman manusia dari berbagai segi kenyataan dalam alam manusia. Segi-segi ini dibatasi agar dihasilkan rumusan-rumusan yang pasti. Ilmu memberikan kepastian dengan membatasi lingkup pandangannya, dan kepastian ilmu-ilmu diperoleh dari keterbatasannya. Ilmu bukan sekadar pengetahuan (knowledge), tetapi merangkum sekumpulan pengetahuan berdasarkan teori-teori yang disepakati dan dapat secara sistematik diuji dengan seperangkat metode yang diakui dalam bidang ilmu tertentu. Dipandang dari sudut filsafat, ilmu terbentuk karena manusia berusaha berfikir lebih jauh mengenai pengetahuan yang dimilikinya. Ilmu pengetahuan adalah produk dari epistemologi (Sutiyono, 2003)

\subsection{Sumber Pengetahuan Manusia}

Sebagaimana telah disebutkan bahwa sumber pengetahuan manusia terdiri dari rasio, pengalaman, intuisi, dan wahyu. Dengan keempat inilah manusia mencari apa yang disebut dengan kebenaran.

1. Rasio

Rasio biasa dikenal sebagai akal pikiran. Kata akal berasal dari bahasa Arab, yaitu ala-'aqil yang dalam bentuk kata benda tidak terdapat dalam Alquran. Ala Quran hanya menyebutnya dalam bentuk kata kerja seperti 'aqaluh, ta'qilun, na'qil, ya'qiluha dan ya'qilun yang mengandung makna dan faham dan mengerti seperti terdapat pada ayat 46 surat ala Haji: "Apakah mereka tidak melakukan perjalanan di permukaan bumi dan mereka mempunyai kalbu untuk memahami atau telinga untuk mendengar; sesungguhnya 
bukanlah mata yang buta, tetapi kalbu di dalam Adalah yang buta. (QS. AlHajj: 46).

Manusia yang menjadikan rasio atau akal sebagai sumber pengetahuan disebut dengan kaum rasionalis yang mengembangkan paham rasionalisme.

Dengan perkataan lain, ide tentang kebenaran, yang menjadi dasar pengetahuan, diperoleh lewat berpikir rasional, terlepas dari pengalaman manusia. Sistem pengetahuan dibangun secara koheren di atas landasanlandasan pernyataan yang sudah pasti. Masalah utama yang timbul dari cara berpikir rasional adalah kriteria untuk mengetahui akan kebenaran dari suatu ide dimana menurut seseorang adalah jelas dan dapat dipercaya namun belum tentu bagi orang lain. Dalam hal ini maka pemikiran rasional cenderung untuk bersifat solipsistic dan subyektif.

Para tokoh rasionalisme di antaranya adalah Plato dan Rene Descartes. Plato menyatakan bahwa manusia tidak mempelajari apapun, dia hanya "teringat apa yang telah diketahui”. Semua prinsip-prinsip dasar dan bersifat umum telah ada dalam pikiran manusia. Pengalaman indera paling banyak hanya dapat merangsang ingatan dan membawa kesadaran terhadap pengetahuan yang selama itu sudah berada dalam pikiran (Alimatus, 2020).

\section{Pengalaman/empiris}

Kebalikan dari kaum rasionalis, maka kaum empiris berpendapat bahwa pengetahuan manusia bersumber pada pengalaman yang konkrit. Gejalagejala alamiah merupakan sesuatu yang bersifat konkret dan dapat dinyatakan lewat tangkapan panca indera manusia. Melalui gejala-gejala atau kejadian-kejadian yang berulang-ulang dan menunjukkan pola yang teratur, memungkinkan manusia untuk melakukan generalisasi. Dengan mempergunakan metode induktif maka dapat disusun pengetahuan yang berlaku secara umum lewat pengamatan terhadap gejala-gejala fisik yang bersifat individual.

Kaum empiris menganggap bahwa dunia fisik adalah nyata karena merupakan gejala yang dapat ditangkap oleh panca indra, sedangkan panca indera manusia sangat terbatas kemampuannya dan terlebih penting lagi bahwa panca indera manusia biasa melakukan kesalahan. Misalnya bagaimana mata melihat sebatang pensil yang dimasukkan ke dalam gelas bagian yang terendam air terlihat bengkok, padahal secara hakikat tetap lurus. 
3. Intuisi

Intuisi merupakan pengetahuan yang didapatkan tanpa melalui proses penalaran tertentu. Seseorang yang sedang terpusat pikirannya pada sesuatu masalah tiba-tiba saja menemukan jawaban atas permasalahan tersebut. Tanpa melalui proses berpikir yang berliku-liku tiba-tiba saja dia sudah sampai pada sebuah kesimpulan. Jawaban permasalahan yang sedang dipikirkannya muncul dibenaknya bagaikan kebenaran yang membukakan pintu. Keingintahuan manusia tentang sesuatu yang berada dibalik materi, tentang siapakah yang berada dibalik keteraturan materi, yang menciptakan hukum-hukumnya bukanlah objek empiris dan bukan pula dapat dijangkau akal rasional dan objek ini dikenal dengan objek abstrak-supra rasional atau meta rasional yang dapat dikenali melalui rasa, bukan pancaindera dan atau akal rasional.

4. Wahyu

Wahyu berasal dari bahasa Arab al-wah\}y dan al-wah\}y adalah kata asli Arab dan bukan kata pinjaman dari bahasa asing. Kata itu berarti suara, api dan kecepatan. Di samping itu ia juga mengandung arti bisikan, isyarat, tulisan dan kitab. AlWahy selanjutnya mengandung pengertian pemberitahuan secara tersembunyi dan dengan cepat. Yang di maksud dengan wahyu sebagai sumber pengetahuan adalah wahyu yang diturunkan kepada orang pilihan agar diteruskan kepada umat manusia agar dijadikan pegangan hidup berisi ajaran, petunjuk dan pedoman yang diperlukan bagi umat manusia di dunia dan akhirat. Dalam Islam wahyu yang disampaikan kepada Nabi Muhammad terkumpul dalam Alquran.

Wahyu yang diturunkan kepada para rasul, memiliki nilai kebenaran yang absolut. Semua ayat yang terdapat dalam Alquran memang absolut benar datang dari Allah yang diistilahkan dengan qat\}'i al-wurud. Namun demikian tidak semua ayat mengandung arti yang jelas (qat $\}^{\prime} i$ al-dala lah) dan banyak di antaranya mengandung arti tidak jelas ( $z$ ann aldala $>$ lah) yang menimbulkan interpretasi berbeda di kalangan umat.4 Wahyu dalam hal ini adalah Alquran merupakan sumber pengetahuan bagi manusia, yang memberikan petunjuk tentang sesuatu yang berguna bagi kehidupan manusia (Hidayat, 2016). 


\subsection{Objek dan Materi Pengetahuan Ilmiah}

Ilmu, sains, atau ilmu pengetahuan (Inggris: science; Arab: العِلْمُ) adalah usahausaha sadar untuk menyelidiki, menemukan dan meningkatkan pemahaman manusia dari berbagai segi kenyataan dalam alam manusia.[1] Segi-segi ini dibatasi agar dihasilkan rumusan-rumusan yang pasti. Ilmu memberikan kepastian dengan membatasi lingkup pandangannya, dan kepastian ilmu-ilmu diperoleh dari keterbatasannya.[2]

Ilmu bukan sekadar pengetahuan (knowledge), tetapi merangkum sekumpulan pengetahuan berdasarkan teori-teori yang disepakati dan dapat secara sistematik diuji dengan seperangkat metode yang diakui dalam bidang ilmu tertentu. Dipandang dari sudut filsafat, ilmu terbentuk karena manusia berusaha berpikir lebih jauh mengenai pengetahuan yang dimilikinya. Ilmu pengetahuan adalah produk dari epistemologi, dengan kata lain ilmu terbentuk dari 3 cabang filsafat yakni ontologi, epistemologi dan aksiologi, jika ketiga cabang itu terpenuhi berarti sah dan diakui sebagai sebuah ilmu (Herwansyah, 2017).

Ilmu alam hanya bisa menjadi pasti setelah lapangannya dibatasi ke dalam hal yang bahani (material saja), atau ilmu psikologi hanya bisa meramalkan perilaku manusia jika lingkup pandangannya dibatasi ke dalam segi umum dari perilaku manusia yang konkret. Berkenaan dengan contoh ini, ilmu-ilmu alam menjawab pertanyaan tentang berapa jarak matahari dan bumi, atau ilmu psikologi menjawab apakah seorang pemudi cocok menjadi perawat.

Istilah "model", "hipotesis", "teori", dan "hukum" mengandung arti yang berbeda dalam keilmuan dari pemahaman umum. Para ilmuwan menggunakan istilah model untuk menjelaskan sesuatu, secara khusus yang bisa digunakan untuk membuat dugaan yang bisa diuji dengan melakukan percobaan/eksperimen atau pengamatan. Suatu hipotesis adalah dugaan-dugaan yang belum didukung atau dibuktikan oleh percobaan, dan hukum fisika atau hukum alam adalah generalisasi ilmiah berdasarkan pengamatan empiris (Amin, 2014).

Objek penelaahan ilmu mencakup seluruh aspek kehidupan yang dapat diuji oleh panca indera manusia. Berdasarkan obyek yang ditelaahnya, maka ilmu dapat disebut sebagai suatu pengetahuan empiris. Inilah yang merupakan salah satu ciri ilmu yakni orientasi terhadap dunia empiris. Soetriono \& Hanafie (1007) dalam Adib, M (1010) menyatakan bahwa Ontologi merupakan asas dalam menerapkan batas atau ruang lingkup wujud yang menjadi objek penelaahan (objek ontologis atau objek formal 
dari pengetahuan) serta penafsiran tentang hakikat realita (metafisika) dari objek ontologi atau objek formal tersebut dan dapat merupakan landasan ilmu yang menanyakan apa yang dikaji oleh pengetahuan dan biasanya berkaitan dengan alam kenyataan dan keberadaan. Setiap ilmu pengetahuan pasti mempunyai objek. Obyek dapat dibedakan menjadi dua bagian, yaitu:

\section{a. Objek Material}

Yang disebut objek material adalah sasaran material suatu penyelidikan, pemikiran atau penelitian ilmu. Sedangkan menurut Surajiyo (1006), objek material dimaknai dengan suatu bahan yang menjadi tinjauan penelitian atau pembentukan pengetahuan. Objek material juga berarti hal yang diselidiki, dipandang atau disorot oleh suatu disiplin ilmu. Objek material mencakup apa saja, baik yang konkret maupun yang abstrak, yang materil maupun yang non-materil. Bisa pula berupa hal-hal, masalah-masalah, ide-ide, konsep-konsep dan sebagainya. Misal: objek material dari sosiologi adalah manusia. Contoh lainnya, lapangan dalam logika adalah asas-asas yang menentukan pemikiran yang lurus, tepat, dan sehat. Makna, berpikir merupakan objek material logika.

Istilah objek material sering juga disebut pokok persoalan (subject matter). Pokok persoalan ini dibedakan atas dua arti, yaitu:

1. Pokok persoalan ini dapat dimaksudkan sebagai bidang khusus dari penyelidikan faktual. Misalnya: penyelidikan tentang atom termasuk bidang fisika; penyelidikan tentang chlorophyl termasuk penelitian bidang botani atau bio-kimia dan sebagainya.

2. Dimaksudkan sebagai suatu kumpulan pertanyaan pokok yang saling berhubungan. Misalnya: anatomi dan fisiologi keduanya berkaitan dengan struktur tubuh. Anatomi mempelajari strukturnya sedangkan fisiologi mempelajari fungsinya. Kedua ilmu tersebut dapat dikatakan memiliki pokok persoalan yang sama, namun juga dikatakan berbeda. Perbedaaan ini dapat diketahui apabila dikaitkan dengan corak-corak pertanyaan yang diajukan dan aspek-aspek yang diselidiki dari tubuh tersebut. Anatomi mempelajari tubuh dalam aspeknya yang statis, sedangkan fisiologi dalam aspeknya yang dinamis.

b. Objek Formal 
Objek formal adalah pendekatan-pendekatan secara cermat dan bertahap menurut segi-segi yang dimiliki obyek materi dan menurut kemampuan seseorang. Objek formal diartikan juga sebagai sudut pandang yang ditujukan pada bahan dari penelitian atau pembentukan pengetahuan itu, atau sudut pandang dari mana objek material itu disorot. Objek formal suatu ilmu tidak hanya memberikan keutuhan ilmu, tetapi pada saat yang sama membedakannya dari bidang-bidang lain. Suatu obyek material dapat ditinjau dari berbagai sudut pandang sehingga menghasilkan ilmu yang berbeda-beda (Imron, 2012).

Gambaran lingkup suatu pengetahuan mengenai sesuatu hal menurut segi tertentu. Dengan kata lain, "tujuan pengetahuan sudah ditentukan. Misalnya, objek materialnya adalah "manusia", kemudian, manusia ini ditinjau dari sudut pandang yang berbeda-beda sehingga ada beberapa ilmu yang mempelajari manusia, diantaranya: psikologi. 


\section{Bab VI \\ Filsafat dan Holisme}

\subsection{Teori Berpikir Holistik}

Dalam Kamus Besar Bahasa Indonesia (KBBI, 2008a) berpikir berasal dari kata pikir yang berarti akal budi, ingatan atau angan-angan. "Berpikir" adalah proses menggunakan akal budi untuk mempertimbangkan dan memutuskan sesuatu atau menimbang-nimbang dalam ingatan atau mempertimbangkan baik-baik segala sesuatunya. Dalam bentuk kata kerja "memikirkan" diartikan mencari upaya untuk menyelesaikan sesuatu dengan akal budi. Berpikir merupakan proses dialektis, yang artinya, selama kita berpikir, dalam pikiran itu terjadi tanya-jawab untuk bisa meletakkan hubungan-hubungan pengetahuan kita dengan tepat.

Jika makna "berpikir" kita telisik dalam dunia filsafat, maka kita akan menemukan berbagai aliran pemikiran yang dicetuskan para filsuf terdahulu mulai dari zaman Yunani kuno hingga pada zaman modern, seperti teori rasionalisme Plato, teori empirisme Aristoteles, dan teori positivisme Auguste Comte dan lain-lain. Rene Descartes misalnya yang dikenal sebagai bapak filsuf modern dan merupakan tokoh penting dalam aliran rasionalisme, "berpikir" dalam pemikiran Descartes selalu melibatkan kesadaran. Sadar akan sesuatu hal. Sadar untuk membuka cakrawala baru, sadar untuk kemudian melibatkan fungsi-fungsi kognitif kita untuk mendapatkan data-data baru dalam pengalaman yang kita olah dalam fungsi berpikir kita, sehingga hampir semua pengetahuan kita tidak ada yang terlepas dari optimalisasi fungsi rasio dalam kognisi manusia (Liana, 2015).

Fungsi rasio dalam konteks rasionalitas manusia benar-benar membedakan manusia dengan binatang yang sama-sama diberikan otak untuk berpikir dakaligus sama-sama merupakan makhluk ciptaan Tuhan. Kondisi inilah oleh Descartes yang dikutip oleh para penulis buku filsafat mengemukakan istilah " $I$ Think Therefore I Think" atau "Cogito Ergo Sum" yang artinya "Jika aku Berpikir maka aku ada", (Sutisna et al., 1017). 
Berbagai teori atau aliran pemikiran manusia dalam dunia filsafat, rupanya belum cukup untuk menjawab secara tuntas berbagai masalah yang terus tumbuh dan berkembang seiring perjalanan kehidupan manusia modern.

Hingga memasuki abad 10 atau sekitar tahun 1916, oleh Jan Christian Smuts perdana Menteri Afrika Selatan 1919-1914 dan 1939-1948 disebut sebagai yang pertama kali memperkenalkan kata "Holistik" yaitu dalam bukunya yang berjudul Holism and Evolution. Smuts mendefinisikan holisme sebagai sebuah kecenderungan alam untuk membentuk sesuatu yang utuh sehingga sesuatu tersebut lebih besar daripada sekedar gabungan-gabungan bagian hasil evolusi (Townsend and Smuts, 1928).

Kata Holisme atau Holistik dalam Kamus Besar Bahasa Indonesia bermakna sebagai cara pendekatan terhadap suatu masalah atau gejala, dengan memandang gejala atau masalah itu sebagai suatu kesatuan yang utuh atau dapat juga diartikan sebagai cara pandang yang utuh dan menyeluruh (KBBI, 1008b). Istilah "holistic" juga diambil dari kata heal (penyembuhan) dan kata health (Kesehatan) dimana secara etimologis memiliki makna yang sesuai dari kata whole (keseluruhan) yang merupakan serapan dari kamus bahasa Inggris (Otto, 2010). Dari makna kata tersebut kemudian dapat didefinisikan bahwa berpikir holistik berarti berpikir sehat atau dalam dunia pendidikan kita kenal dengan istilah pendidikan holistik yang didefinisikan sebagai sebuah metode pendidikan atau pembelajaran yang membangun manusia secara utuh dengan menggali semua potensi yang dimiliki oleh setiap individu yang mencakup potensi sosial, potensi emosi, potensi intelektual, potensi fisik, potensi moral, potensi kreatifitas maupun potensi spiritual, semua itu akan bermuara terbentuknya manusia holistik dimana manusia holistik adalah manusia yang mampu mengembangkan dirinya (Megawangi, 2005 dalam Yogiswari, 2018).

Studi hukum analitis misalnya yang mengawali ilmu hukum modern, orang hanya mendapat panduan dalam hal memahami dan mengoperasikan hukum positif. Padahal sebagai ilmu yang otentik, maka ilmu hukum dituntut untuk bisa memberikan dan menampilkan gambar yang lebih utuh tentang hukum. Misalnya psikologi modern telah gagal untuk menyajikan gambar tentang manusia secara utuh, karena hanya menampilkan gambar tentang kepingankepingan jiwa manusia. Untuk memperoleh gambaran yang utuh tentang hukum, maka kesalahan tersebut perlu diperbaiki, yaitu dengan mengaitkan dunia positif-normatif kepada dunia kehidupan nyata (Budiono, 2018).

Metodologi analitis Cartesian, Baconian, dan Newtonian tidak membawa kita kepada pemahaman yang benar tentang alam dan kehidupan. Metodologi baru 
yang menggantikan harus mengutuhkan, bukan memisah-misahkan. Pendekatan demikian disebut dengan pendekatan dan metodologi holistik. Paradigma holistik dapat mengubah peta berhukum dan pembelajaran hukum yang selama ini memandu kita (Rahardjo, 2005 dalam Budiono, 2018).

Hukum secara holistik memiliki ontologi hukum yaitu ilmu tentang segala sesuatu (merefleksi hakikat hukum dan konsep-konsep fundamental dalam hukum, seperti konsep demokrasi, hubungan hukum dan kekuasaan, hubungan hukum, dan moral). Aksiologi hukum yaitu ilmu tentang nilai (merefleksi isi dan nilai-nilai yang termuat dalam hukum seperti kelayakan, persamaan, keadilan, kebebasan, kebenaran, dan sebagainya). Ideologi hukum yaitu ilmu tentang tujuan hukum yang mengangkut cita manusia (merefleksi wawasan manusia dan masyarakat yang melandasi dan melegitimasi kaidah hukum, pranata hukum, sistem hukum dan bagian-bagian dari sistem hukum) (Budiono, 2018)

\subsection{Paradigma Holistik}

\subsubsection{Pengertian Paradigma}

Paradigma sebagai gugusan sistem pemikiran memiliki pengertian yang beragam. Secara etimologis, kata paradigma berasal dari Bahasa Yunani, yaitu paradeinumi (menunjukan, mewakili, mengekspos) kemudian dibagi menjadi dua suku kata yaitu para (di samping atau bersebelahan) dan deiknumi (menunjukan atau memperlihatkan). Kata paradigma kemudian diserap dalam Bahasa Inggris paradigm yang berarti suatu model atau pola. Dalam kamus Webster paradigma dimaknai; a pattern or model - an overall concept accepted by most people in an intellectual community, as science, because of its effectiveness in explaining a complex process, ide, or set of data atau dalam terjemahan bebas Bahasa Indonesia bermakna pola atau model - konsep keseluruhan yang diterima oleh kebanyakan orang dalam komunitas intelektual, sebagai sains, karena keefektifannya dalam menjelaskan proses, ide, atau kumpulan data yang kompleks (Townsend, 1928).

Paradigma dapat juga diartikan sebagai gagasan atau konsep, nilai yang diterapkan dalam memahami sebuah realitas dalam komunitas yang sama terutama dalam disiplin intelektual. Thomas Kuhn menulis dalam bukunya yang 
berjudul The Structure of Scientific Revolution, dimana ia menggunakan istilah paradigma dengan banyak arti, seperti, model atau pola berpikir, matriks disipliner, termasuk pandangan dunia (worldview) kelompok intelektual atau kaum ilmuwan (Syaifuddin Sabda, 1010). Sedangkan menurut Robert A. Friedrichs dalam Sociology of Sociology paradigma adalah konsistensi dari proses keilmuan (Maragustam, 2012)

Tinjauan aspek disiplin intelektual paradigma adalah merupakan pandangan seseorang terhadap diri dan lingkungannya yang dapat mempengaruhinya dalam berpikir (kognitif), bersikap (afektif), dan bertingkah laku (psikomotorik). Dalam sebuah paradigma terkandung di dalamnya asumsi-asumsi ontologis dan epistemologis tertentu, visi realitas, dan sistem nilai. Dalam hal ini dapat dibedakan antara paradigma biasa dengan paradigma dalam arti pandangan dunia. Perbedaan pokok antara paradigma biasa dengan paradigma yang dalam arti pandangan dunia adalah bahwa pandangan dunia merupakan paradigma atau cara pandang yang dianut secara persuasif dan terkandung di dalamnya asumsi-asumsi ontologis dan epistemologis tertentu, visi realitas, dan sistem nilai. Dalam paradigma yang diartikan sebagai pandangan dunia, menurut Herwansyah (2017) mengandung dua komponen utama, yaitu prinsip-prinsip dasar dan kesadaran intersubjektif.

\subsubsection{Hegemoni Paradigma Cartesian-Newtonian}

Jika dilacak dalam sejarah, kita akan menemukan tokoh yang paling berpengaruh terhadap perkembangan peradaban dunia modern yaitu Rene Descartes (1596-1650) dan Sir Isaac Newton (1641-1717) yang kemudian dalam perkembangan ilmu pengetahuan, sains dan teknologi kedua tokoh ini didaulat sebagai bapak peradaban dunia modern atau akrab dengan istilah "Paradigma Cartesian-Newtonian".

Dalam perkembangan dunia modern, paradigma Cartesian-Newtonian menjelma sebagai pemikiran besar dunia tidak terbatas menghegemoni dunia sains dan teknologi tetapi merambah hingga ke semua bidang ilmu pengetahuan dan praktek interaksi kehidupan, termasuk bidang ilmu Pendidikan. Paradigma ini menyatu dan built-in dalam pelbagai dimensi kehidupan manusia baik dalam konteks wacana ilmiah, maupun kehidupan sosial-budaya, seolah telah menjadi kesadaran kolektif manusia modern. Menurut Mahzar (2003) dalam (Syaifuddin, 2020), telah menyebabkan para ilmuwan secara tidak sadar telah menjadikan mekanisme materialistik sebagai "dogma" ilmiah yang dianutnya, 
jika mereka beragama dengan dogma-dogma teologis yang mereka yakini, sementara yang ateis menganggap paradigma tersbut sebagai penguat keyakinan teologis mereka (Sisdiknas, 2003).

Paradigma Cartesian-Newtonian memperlakukan manusia dan sistem sosial seperti mesin besar yang di atur menurut hukum-hukum objektif, mekanis, deterministik, linear dan materialistik. Cara pandang ini menempatkan materi sebagai dasar dari semua bentuk eksistensi, dan menganggap alam kosmos sebagai kumpulan dari objek-objek yang terpisah yang dirakit menjadi sebuah mesin raksasa.

\subsubsection{Paradigma Holistik sebagai Solusi}

Menurut Fritjof Capra, krisis-krisis global di muka bumi dapat dilacak pada cara pandang dunia manusia modern. Pandangan-dunia (Worldview) yang diterapkan selama ini adalah pandangan dunia mekanistik-linier CartesianNewtonian (paradigma Cartesian-Newtonian). Paradigma ini di satu sisi berhasil mengembangkan dunia sains sehingga mempermudah kehidupan manusia, namun di lain sisi mereduksi kompleksitas dan kekayaan kehidupan manusia itu sendiri. Pandangan ini melahirkan berbagai macam pencemaran di udara, air, tanah yang justru mengancam balik kehidupan manusia. Penekanan yang berlebihan pada metode ilmiah eksperimental dan rasional analitis telah menimbulkan sikap-sikap yang anti ekologis (Husain Heriyanto, 1003 dalam Imron Saefuddin, 2012).

Percaturan pemikiran manusia modern yang senantiasa dinamis akibat hegemoni paradigma Cartesian-Newtonian, kemudian bermunculan kritik atas hegemoni tersebut dan tidak sedikit para kritikus menuangkan pemikirannya dalam berbagai karya ilmiah baik dalam bentuk buku, jurnal, disertasi, tesis, skripsi, maupun dalam berbagai artikel. Husein Haryanto misalnya dalam bukunya berjudul Paradigma Holistik; Dialog Filsafat, Sains, dan Kehidupan Menurut Shadra dan Whitehead, 2003, mengemukakan pemikiran tentang paradigma holistik-dialogis. Paradigma holistik-dialogis disebutkan memiliki empat karakter, yaitu, Karakter "pertama" dalam sistem paradigma holistikdialogis adalah pandangan ontologis yang mengkonstruksi realitas yang padat, beku dan statis. Sistem paradigma holistik-dialogis membalikkan skema metafisika Aristoteles. Karakter "kedua" filsafat holistik-dialogis adalah sibernetik ekologis. Maksudnya adalah sebagai suatu pandangan yang memperlakukan alam raya sebagai sistem hidup yang memiliki sistem 
pengendalian dan pengaturan diri. Karakteristik "ketiga" paradigma holistikdialogis berkaitan dengan pandangan antropologisnya bahwa "subjek" merupakan pengertian yang berkorelasi dengan subjek-subjek lain. Karakter "keempat", paradigma holistik juga berkarakter realis pluralis, kritis konstruktif, dan sintesis-dialogis. Oleh karena dibangun atas dasar dialog dan sintesis, maka paradigma holistik ini dapat berdialog dengan pelbagai wilayah peradaban manusia, seperti dunia sains, kebudayaan kontemporer dan realitas kehidupan global dengan segenap problematikanya (Husain Heriyanto, 1003 dalam Imron Saefuddin, 2012).

Konsepsi pemikiran tentang paradigma holistik telah merambah ke berbagai dimensi keilmuan termasuk dalam ilmu hukum. Salah satu pelopor paradigma holistik dalam Ilmu Hukum adalah Satjipto Rahardjo yang mengemukakan bahwa ilmu hukum positif telah gagal untuk menyajikan gambar hukum yang lebih benar (Budiono, 2018). Hukum secara holistik sebagaimana dikemukakan sebelumnya memiliki ontologi hukum yaitu ilmu tentang segala sesuatu yakni mampu merefleksi hakikat hukum dan konsep-konsep fundamental dalam hukum, seperti konsep demokrasi, hubungan hukum dan kekuasaan, hubungan hukum dan moral.

\subsection{Relevansi Pendidikan Holistik}

Pendidikan adalah sebuah kata yang memiliki beragam definisi, bahkan karena pendidikan telah menjadi kebutuhan dasar umat manusia sekaligus menjadi titik tolak dalam perkembangan peradaban, maka kata pendidikan itu sendiri tidak pernah memiliki titik akhir untuk di perbincangkan. Pendidikan pada hakikatnya tidak hanya sekedar untuk mengembangkan potensi intelektualitas dan keterampilan peserta didik, tetapi pendidikan diharapkan mampu menanamkan etika, dan akhlak yang baik dalam berbagai dimensi kehidupan manusia.

Undang-undang No. 10 Tahun 1003 pada Bab II pasal 3, disebutkan bahwa "Tujuan pendidikan nasional adalah mengembangkan potensi peserta didik agar menjadi manusia yang beriman dan bertakwa kepada Tuhan Yang Maha Esa, berakhlak mulia, sehat, berilmu, cakap, kreatif, mandiri, dan menjadi warga negara yang demokratis serta bertanggung jawab" (Sisdiknas No. 10 Thn. 2003). Untuk mendukung tujuan pendidikan nasional maka aspek lingkungan yang terdiri dari lingkungan keluarga, masyarakat dan sekolah harus 
dikolaborasikan secara seimbang karena setiap pembelajaran dipengaruhi ketiga lingkungan ini (Dahlan 2016 dalam Yuliana, R and Fahri, 2020). Yuliana dan kawan-kawan menekankan pendidikan holistik pada aspek karakter karena pendidikan karakter tidak hanya berbicara tentang benar-salah, akan tetapi bagaimana menanamkan kebiasaan (habit) tentang hal-hal yang baik dalam kehidupan, sehingga peserta didik memiliki kesadaran, dan pemahaman yang tinggi, serta kepedulian dan komitmen untuk menerapkan kebaikan dalam kehidupan sehari-hari. Dengan demikian dapat dikatakan bahwa karakter merupakan sifat alami seseorang dalam merespon situasi secara bermoral, yang diwujudkan dalam tindakan nyata melalui perilaku baik, jujur, bertanggung jawab, hormat terhadap orang lain, dan nilai-nilai karakter mulia lainnya (Yuliana et al.,, 2020).

Pendidikan harus mengenalkan peserta didik tentang isu-isu penting yang dihadapi oleh kemanusiaan, sekaligus harus mampu memberikan pemecahan atas masalah-masalah kemanusiaan tersebut. Dengan demikian, peserta didik memiliki kesadaran tentang hakikat dirinya, yaitu siapa, untuk apa, dan bagaimana. Kehidupan seorang manusia bermakna manakala mampu memberikan kedamaian, kebahagiaan, dan pencerahan bagi orang-orang sekitarnya. Pendidikan dengan gambaran seperti itu dinamakan dengan pendidikan holistik (Lubis, 2015).

\subsection{Konsep dan Teori Lahirnya Filsafat}

Sesungguhnya manusia telah berfilsafat sejak dahulu bahkan jauh sebelum istilah filsafat itu sendiri kita kenal dalam ranah Ilmu Pengetahuan. Berbagai situs purbakala dan temuan-temuan sejarah memperlihatkan secara kasat mata bahwa peradaban manusia sejak dahulu telah ada dan berkembang sesuai zamannya. Kemegahan piramida Mesir misalnya tidak dibangun dengan konsep Pythagoras mengenai trigonometri namun yang pasti Piramida Mesir tidaklah mungkin dibangun kecuali dengan perhitungan atau dengan logika yang tepat. Begitu pulah Bangsa Saba di wilayah Yaman telah membangun sistem irigasi yang mengantarkannya menjadi bangsa yang makmur, bahkan jauh sebelum Aristoteles mendirikan Sekolah yang diberi nama Lyceum. Jika kita telisik dalam sejarah mulai dari zaman neolitik, zaman perunggu hingga zaman besi maka kita dapat mengetahui bahwa dari situlah titik awal peradaban manusia 
dimulai. Di zaman neolitik misalnya, manusia sudah mulai bercocok tanam dan bermukim, kemudian zaman perunggu ditandai dengan adanya pembentukan kota dan urbanisasi, dan selanjutnya pada zaman besi pada masa mesir sekitar tahun 1500 SM ditandai dengan adanya sistem pemerintahan dan berdirinya bangunan-bangunan bersejarah yang masih kita saksikan hingga hari ini (Manan, 2020).

Semua peradaban manusia yang menakjubkan itu tidaklah mungkin lahir begitu saja melainkan hasil dari pemikiran dan kontemplasi manusia dengan alam dan segala isinya. Proses perenungan ini lahir dari keinginan dalam diri manusia sebagai bentuk rasa ingin tahu. Rasa ingin tahu inilah yang kemudian dirumuskan dan menjadi disiplin ilmu yang dikenal dengan filsafat.

Kata filsafat berasal dari bahasa Yunani, yaitu philosophia yang bersumber dari dua suku kata philos yang berarti cinta atau sahabat dan kata sofia yang berarti kebijaksanaan, kearifan, kebenaran atau pengetahuan. Jadi, philosophia bermakna sebagai cinta kepada kebijaksanaan atau cinta kepada kebenaran, yaitu kebenaran ilmu pengetahuan. Dari sisi filsafat sebagai ilmu, para tokoh filsuf mulai dari zaman Yunani kuno hingga pada zaman modern telah melahirkan berbagai pengertian berdasarkan landasan teori yang dianut masingmasing, diantaranya adalah:

Plato (417-347 SM) mendefinisikan filsafat sebagai penemuan kenyataan atau kebenaran atau sebagai ilmu pengetahuan yang berusaha mencapai kebenaran yang asli, karena kebenaran mutlak bersifat transenden. Aristoteles, murid Plato (384-311 SM) mengatakan bahwa filsafat menyelidiki sebab dan asas segala benda atau sebagai ilmu pengetahuan yang meliputi kebenaran yang terkandung didalamnya ilmu metafisika, logika, retorika, politik, sosial budaya dan etika. Cicero (106 SM - 43SM), Filsafat adalah pengetahuan tentang sesuatu yang maha agung dan usaha-usaha untuk mencapainya.

Al Farabi (870-950 M), filsafat adalah pengetahuann tentang yang ADA menurut hakikatnya yang sebenarnya atau filsafat sebagai ilmu pengetahuan tentang sifat, bagaimana sifat sesungguhnya dari kebenaran (Wiyono, 2016). Ibnu Sina (980-1037), Filsafat adalah ilmu pengetahuan tentang alam maujud dan bertujuan menyelidiki hakikat yang sebenarnya (Herwansyah, 2017).

Rene Descartes (1596-1650 M), Filsafat adalah kumpulan semua pengetahuan bahwa Tuhan, manusia dan alam menjadi pokok penyelidikan.

Immanuel Kant (1714-1804 M), mengatakan filsafat sebagai ilmu pokok dan pangkal segala pengetahuan yang mencakup didalamnya empat persoalan, 
yaitu; apa yang dapat kita ketahui, dijawab oleh metafisika; apa yang boleh kita kerjakan, dijawab oleh etika; apa yang dinamakan manusia dijawab oleh antropologi; sampai dimana harapan kita, dijawab oleh agama.

Hegel (1770-1831) berpendapat bahwa filsafat bertugas untuk mendeduksi kategori-kategori untuk menemukan hakikat semua hal. Hasbullah Bakry, berpendapat filsafat adalah ilmu yang menyelidiki segala sesuatu dengan mendalam mengenai Ketuhanan, alam semesta, dan manusia sehingga dapat melahirkan pengetahuan tentang bagaimana hakikatnya sejauh yang dicapai manusia (Sutisna, 2017).

Filsafat dalam mengulas tentang Alam, akan mengingatkan kita pada beberapa filsuf Dunia yang hidup sekitar abad ke-4 hingga abad ke-1 SM, diantaranya Thales, Anaximenes, Herakleitos, Phytagoras, Keukippos, Demokritos, dan Emoedokles. Beberapa nama ini telah berupaya untuk menemukan jawaban atas pertanyaan yang begitu mendasar mengenai apakah asal mula atau dasar dari segala sesuatu yang ada dalam alam ini. Mereka mencoba membangun konsepsi pemikiran atas realitas yang ada disekitarnya, mencoba memahami dan berusaha merasakan kenyataan hidup manusia sehingga melahirkan argumentasi teoritis yang hingga hari ini menjadi pijakan teori para filsuf modern atau para ahli filsafat (Poedjiadi and Al-Muchtar, 2014).

1. Thlaes, yang diperkirakan hidup antara tahun (614-548 SM) disebut-sebut sebagai filsuf pertama yang berusaha mencari jawaban atas pertanyaan asal mula segalah benda yang ada di alam ini. Thales yang tinggal di sebuah pulau, setiap hari ia melihat lautan luas, dimana lautan tersebut tidak hanya memberikan manfaat bagi kehidupan masyarakat, tapi juga sering menjadi sumber bencana bagi para nelayan. Ketika melakukan perjalanan ke Mesir, Thales menyaksikan dimana sungai Nil menjadi salah satu sumber penghidupan Penduduk dengan memanfaatkan sebagai keperluan pertanian. Atas realitas yang disaksikan, Thales berpendapat bahwa air yang senantiasa bergerak adalah asal segala yang ada dan dipandangnya sebagai asas kehidupan segala yang ada, menurut Thales tanpa air manusia tidak dapat mempertahankan kehidupannya.

2. Anaximenes yang hidup antara tahun (585-518 SM) mengemukakan pendapat yang berbeda dari Thales. Pandangan Anaximenes berpijak pada landasan konsepsi bahwa semua makhluk hidup itu bernafas termasuk manusia, yaitu bernafas dengan udara yang melingkupi alam semesta. Tanpa udara sebagai sumber kehidupan, seluruh makhluk akan mati. Jadi menurut Thales udaralah asal dari segala yang ada. 
3. Herakleitos yang hidup sekitar tahun (540-480 SM), bijakan pemikirannya berdasar pada kenyataan bahwa tidak ada yang kekal di alam semesta ini, karena segala sesatu yang ada dapat mengalami perubahan, jadi menurut Herakleitos hakikat atas segala sesuatu ada perubahan itu sendiri. Perubahan oleh Herakleitos dilambangkan sebagai sifat api, dan karena itu ia berpendapat bahwa dasar segala sesuatu adalah api. Perubahan tidak terjadi secara alami, tetapi perubahan itu mesti berlaku dibawah suatu hukum yang disebutnya logos, yang artinya pikiran yang benar.

4. Phytagoras yang hidup sekitar tahun (580-500 SM) dan menetap di Kota Kroton di sebuah wilayah yang terletak di Italia Selatan, begitu populer namanya hingga hari ini terutama jika kita bersentuhan dengan cabang ilmu matematika"trigonometri" yang dikenal dengan rumus Phytagoras. Semasa hidupnya dikenal sebagai sosok yang selalu berusaha membersihkan rohaninya untuk mencapai kesempurnaan hidup. Sebagai ahli matematika, pada murid-muridnya, lalu mengajarkan bahwa asal mula segala sesuatu adalah angka atau bilangan. Karena pandangannya tentang alam semesta bertitik tolak dari bilangan, yang kemudian melahirkan pendapat bahwa alam semesta ini tersusun sebagai bilangan-bilangan, maka untuk memperoleh pengetahuan tentang alam ini manusia harus memiliki pengetahuan menganai bilangan.

5. Leukippos, hidup antara tahun (450-410 SM), disebut-sebut sebagai yang pertama mengemukakan tentang atom. Pendapat Leukippos kemudian dikembangkan oleh Demokritos sehingga dalam perkembangan sejarah manusia, jika kita membahas tentang teori atom, maka kedua filsuf ini dianggap memiliki sumbangsi awal terhadap teori tersebut. Leukippos mengemukakan pandangannya bahwa segala sesuatu yang ada terdiri atas atom-atom dan ruang kosong, yang jumlahnya tak terhingga. Sebuah benda atau materi memiliki perbedaan dengan yang yang lain karena memiliki susunan, bentuk, dan posisi serta tumbukan antar atomnya. Kata atom sendiri berasal dari bahasa Yunani atomos yang berarti tidak dapat dibagi, oleh karenanya Leukippos sampai pada pendapat akhir bahwa atom itu tidak dapat dibagi.

6. Democritus hidup antara tahun (460-370 SM) memiliki landasan teori yang sesuai dengan Leukippos mengenai asal alam dan segala sesuatu yang ada. Sisi perbedaannya adalah konsepsi pemikiran Demokritos yang mengembangkan pemikiran Leukippos dimana ia mengemukakan bahwa alam semesta terdiri dari atom-atom dan ruang hampa. Atom-atom itu bebas 
bergerak dan dapat mengubah posisinya. Atom bersifat kekal, tak dapat dilihat, dan tak dapat dibagi. Atom berbeda satu dengan yang lain dari ukuran, posisi, susunan, berat, dan kecepatannya. Benda yang tampak sesungguhnya merupakan kumpulan atom-atom dan benda yang stabil terdiri atas atom-atom yang saling berkaitan. Perubahan wujud benda disebabkan oleh gerakan, tumbukan, dan pengikatan kembali atom-atom tersebut. Demokritos juga berpendapat bahwa Indra dan pikiran adalah dampak dari gerakan atom-atom. Suatu benda tampak oleh mata karena atom-atomnya yang selalu bergerak menyentuh atom-atom Indera kita.

7. Empedokles hidup sekitar tahun (490-430 SM), berbeda dengan yang lain dimana dikemukakan pandangannya bahwa alam semesta terdiri dari empat unsur utama, yaitu udara, air, api, dan tanah. Setiap unsur memiliki sifat yang berbeda satu sama lain, misalnya udara bersifat dingin, air bersifat basah, tanah bersifat kering, dan api bersifat panas. Setiap benda memiliki bentuk karena percampuran dari empat unsur tersebut. Dalam aktivitas hidupnya, Empedokles banyak dipengaruhi oleh sikap hidup Phytagoras karenanya ia memiliki pendapat bahwa disamping empat unsur penyebab terjadinya suatu benda, juga terdapat dua kekuatan yang sangat berpengaruh yaitu cinta dan kebencian. Jika sesuatu terbentuk dan menjadi ada karena kekuatan cinta dari empat unsur utama, maka sesuatu itu dapat pula binasa karena terpisahnya antara empat unsur utama dibawah pengaruh kekuatan kebencian (Middya, 2017).

Jika menelaah pandangan dan argumentasi masing-masing, kita dapat memahami bahwa berfilsafat berawal dari cara menggunakan nurani dan akal kita untuk berpikir kritis guna memperoleh makna dan hakikat hidup atas realitas yang ada.

Dalam ilmu filsafat dikenal beberapa pandangan dan konsepsi pemikiran bahkan dianggap sebagai teori, diantaranya teori "idealisme" Plato, teori "humanisme" diera kebangkitan atau renaissance, teori "rasionalisme" Rene Descartes, John Locke, Jean Jacques Rousseau, dan Johann Bernhard Basedow, teori "Empirisme" Francis Bacon, Thomas Hobbes, teori "Kritisisme" Immanuel Kant, teori "Konstruktivisme" Giambattista Vico, Jean Piaget, E. Von Glasersfeld, The Liang Gie, dan lain-lain.

Pada awalnya filsafat dianggap sebagai segenap ilmu, kemudian berkembang menjadi semakin rasional dan sistematis. Para ahli dengan mempertimbangkan semakin luasnya bidang ilmu yang dibahas dalam filsafat, maka kemudian para ahli membaginya dalam beberapa cabang filsafat. Sebagai gambaran kita 
mengambil dua pembagian cabang filsafat menurut pendapat Harry Hamersma dan menurut The Liang Gie (Lubis, 2015).

Menurut Harry Hamersma, cabang-cabang filsafat dibagi menjadi empat cabang utama yaitu:

1. Filsafat tentang pengetahuan, dimana membahas mengenai:
a. Epistemologi
b. Logika
c. Kritik Ilmu

2. Filsafat tentang kenyataan menyeluruh:
b. Metafisika khusus
a) teologi metafisika
b) anthropologie
c) kosmologi

a. Metafisika umum (ontologi)

3. Filsafat tentang tindakan:
a. Etika
b. Estetika

4. Sejarah filsafat.

Adapun menurut The Liang Gie ilmu filsafat dibagi menjadi tujuh cabang antara lain:

1. Metafisika, cabang filsafat ini berbicara tentang hal ada;

2. Epistemologi, membahas mengenai teori pengetahuan;

3. Metodologi, teori yang berbicara tentang metode;

4. Logika, membahas mengenai teori tentang penyimpulan;

5. Etika, mengulas filsafat dalam pertimbangan moral;

6. Estetika, mengulas filsafat tentang keindahan; dan 
7. Sejarah filsafat.

\subsection{Filsafat Holisme dan Ekologis}

Pembahasan mengenai filsafat holisme dan ekologis, penulis mencoba menyingkap pemikiran Fritjof Capra dalam mendeskripsikan kehidupan sebagaimana tujuan dalam penulisan bukunya yang berjudul The Hidden Connection (Koneksi-koneksi Tersembunyi), yaitu untuk mengembangkan suatu kerangka konseptual yang mengintegrasikan dimensi biologis, kognitif, dan sosial kehidupan. Suatu kerangka pemikiran yang memungkinkan manusia menggunakan sebuah pendekatan sistemik terhadap sejumlah permasalahan krisis dunia modern. Analisis sistem kehidupan dalam empat perspektif yang saling bertautan yaitu bentuk, materi, proses dan makna. Cara membangun pemahaman sistemik yang utuh atas kehidupan, bahwa pola dasar organisasinya adalah jaringan. Dimana pada semua tingkat kehidupan dari jaringan-jaringan metabolisme dalam sel sampai jaringan-jaringan makanan pada ekosistem dan jaringan komunikasi pada masyarakat merupakan komponen-komponen sistem kehidupan yang saling berhubungan dalam jaringan. Sintesis pemikiran Capra dikonstruksikan dalam esensi pemaknaan tentang kehidupan, pikiran dan kesadaran, serta esensi realitas (Otto, 2010).

\subsubsection{Esensi Kehidupan}

Sintesis pemikiran Capra dalam hal esensi kehidupan didasarkan pada perbedaan antara dua perspektif mengenai hakikat sistem kehidupan yaitu,"perspektif pola" (pattern perspective) atau "perspektif struktur" (structure perspective), dimana integrasi keduanya melalui "perspektif proses" (process perspective) atau disebut sebagai perspektif ketiga. Secara khusus, Capra mendefinisikan pola organisasi suatu sistem hidup sebagai konfigurasi hubungan di antara bagian-bagian sistem yang paling menentukan ciri esensial sistem tersebut, yakni "struktur sistem" sebagai perwujudan materi atas pola organisasinya, dan proses kehidupan sebagai proses perwujudan yang terus menerus. Istilah yang lebih umum, perspektif mengenai hakikat sistem hidup dimaknai sama dengan studi"bentuk" atau (pola organisasi), studi materi atau (struktur material), dan studi proses (Otto, 2010). 
Jika mengulas sistem-sistem kehidupan dari perspektif bentuk, maka kita akan menemukan bawah pola organisasi sistem tersebut adalah suatu jaringan yang membentuk diri sendiri. Adapun perspektif materi, struktur material suatu sistem hidup merupakan struktur disipatif, yaitu sebuah sistem terbuka yang beroperasi jauh dari keseimbangan. Sedangkan perspektif proses, sistem kehidupan merupakan sistem kognitif dimana proses kognisi erat kaitannya dengan pola autopoietik (pemahaman yang lebih kompleks).

Selain ketiga perspektif di atas, juga terdapat perspektif pemahaman makna atau sebagai perspektif keempat menurut Capra. Bahwa pemahaman sistemik atas kehidupan dapat diperluas ke arah sosial dengan menambahkan perspektif makna pada kehidupan. Capra memakai "makna" sebagai kependekan bagi dunia dalam kesadaran reflektif yang mengandung banyak ciri yang saling berhubungan. Suatu pemahaman yang lengkap atas fenomena sosial, karenanya harus melibatkan integrasi empat perspektif yakni bentuk, materi, proses, dan makna (Malikah, 2013).

\subsubsection{Esensi Pikiran dan Kesadaran}

Salah satu implikasi filosofis terpenting yang merupakan pemahaman baru tentang kehidupan adalah gambaran mengenai hakikat pikiran dan kesadaran, yang kemudian menggantikan pembagian Cartesian antara pikiran dan materi. Sekitar abad ke-17, Rene Descartes mendasarkan pandangannya terhadap alam dengan melakukan pembagian fundamental dalam dua ranah yang independen dan terpisah yaitu pikiran sebagai benda berpikir (res cogitans) dan materi sebagai benda bertempat (res extensa). Secara konseptual, pemisahan ini telah merambah sains dan filsafat Barat selama lebih dari 300 tahun (Otto, 2010).

Dari alur berpikir Descartes, para ilmuwan dan filsuf terus menilai dan menempatkan pikiran sebagai suatu entitas yang tidak dapat diindra (intangible entity). Para ilmuwan dan filsuf cenderung kesulitan bagaimana benda berpikir ini berhubungan dengan raga fisik. Meskipun para ahli neurosains sejak abad ke-19 telah mengetahui bahwa struktur otak dan pembagian fungsi mental berhubungan sangat dekat, namun hubungan yang pasti antara pikiran dan otak senantiasa menjadi misteri. Alternatif sistem pada kehidupan yang sangat menentukan adalah dengan cara mengabaikan gagasan Cartesian pada pikiran sebagai suatu benda, lalu menyadari bahwa pikiran dan kesadaran itu bukanlah sebuah benda melainkan proses. 
Teori kognisi kontemporer yang digagas oleh Humberto Maturana dan Francisco Varela dari universitas Santiago, Chili atau biasa disebut dengan teori Kognitif Santiago, mengungkapkan bahwa sistem-sistem hidup, pikiran atau kesadaran bukanlah sebuah objek atau entitas benda, namun sebuah proses. Proses tersebut adalah proses kognisi-proses untuk memahami-proses kecerdasan, yang kemudian teridentifikasi dengan proses hidup itu sendiri (Sutiyono, 2003).

Antonius Atosokhi Gea mendefinisikan kesadaran diri sebagai pemahaman terhadap kekhasan fisik, kepribadian, watak dan temperamennya: mengenal bakat-bakat alamiah yang dimilikinya dan punya gambaran atau konsep yang jelas tentang diri sendiri dengan segala kekuatan dan kelemahannya. Sedangkan Soemarno Soedarsono menjelaskan bahwa kesadaran diri merupakan perwujudan jati diri pribadi seseorang, dapat disebut sebagai pribadi yang berjati diri tatkala dalam pribadi orang yang bersangkutan tercermin penampilan, rasa cipta dan karsa, sistem nilai (value system), cara pandang (attitude) dan perilaku (behavior) yang ia miliki (Antonius Atosokhi Gea, dkk, 2001 dan Soemarno Soedarsono, 2000 dalam Malikah, 2013).

\subsubsection{Esensi Realitas Sosial}

Mengaplikasikan pengetahuan manusia atas jaringan-jaringan kehidupan ke fenomena sosial, manusia perlu mengetahui terlebih dahulu apakah konsep auto puitik berlaku di rana sosial. Capra lebih senang memakai istilah auto puitik sebagai satu ciri yang mendefinisikan kehidupan, namun dalam pembahasan mengenai organisasi-organisasi manusia, Carpa mengusulkan bahwa sistemsistem sosial dapat dianggap hidup dan berkembang dalam berbagai level tingkatan. Maksudnya adalah mengidentifikasi interaksi dan komunikasi sebagai unsur jaringan-jaringan sosial. Sistem sosial menggunakan komunikasi sebagai cara khusus reproduksi auto puitik mereka. Unsur-unsurnya adalah komunikasi yang intens dan berulang kali diproduksi dan direproduksi oleh suatu jaringan komunikasi dan tidak dapat berada diluar jaringan tersebut. Jaringan-jaringan komunikasi tersebut membentuk membentuk secara mandiri diri sendiri dimana tiap komunikasi menciptakan pemikiran dan makna, untuk menghasilkan komunikasi lebih lanjut, sampai keseluruhan jaringan menghasilkan dirinya sendiri. Jika komunikasi dilakukan berulang-ulang dalam banyak lingkaran umpan balik, akan menghasilkan suatu sistem kepercayaan, penjelasan, dan nilai bersama yakni sesuatu yang memiliki konteks makna 
universal yang terus menerus dipelihara oleh komunikasi lebih lanjut (Liana, 2020).

Konteks makna milik bersama tersebut, setiap individu akan memperoleh identitas sebagai anggota jaringan sosial, dan dengan sendirinya jaringan tersebut menghasilkan batasannya sendiri. Batasan dalam konteks ini, bukan fisik akan tetapi merupakan batas harapan, kesetiaan dan kerahasiaan yang terpelihara secara berkelanjutan dan dapat dirundingkan kembali oleh jaringan itu sendiri. Sebagai implikasi menempatkan sistem sosial sebagai jaringanjaringan komunikasi, maka manusia dapat mengharapkan jaringan komunikasi mempunyai efek ganda, yakni disatu sisi jaringan-jaringan komunikasi akan menghasilkan gagasan dan konteks makna, dan disisi lain jaringan-jaringan komunikasi menghasilkan aturan-aturan perilaku struktur-struktur sosial (Middya, 2017).

\subsubsection{Hakikat Manusia, Alam Semesta, dan Masyarakat dalam Konteks Pendidikan Islam}

\section{a. Hakikat Manusia dalam Perspektif Filsafat Islam}

Dalam perspektif filsafat Islam, setidaknya terdapat empat aliran pemikiran yang berkaitan tentang masalah jasmani dan rohani dalam arti sudut pandang pembentuk manusia, yaitu aliran serba zat, aliran serba rohani, aliran dualisme, dan aliran eksistensialisme (Alimatus, 2020).

1. Aliran Serba Zat (Faham Materialisme)

Dalam aliran pemikiran serba zat, pera penganutnya mengatakan bahwa yang sungguh-sungguh ada itu adalah zat atau materi, alam ini termasuk segala isinya adalah zat atau materi dan manusia adalah unsur dari alam, oleh karena itu manusia adalah zat atau materi. Manusia adalah apa yang nampak sebagai wujudnya, terdiri atas zat yakni, darah, daging, tulang.

Aliran tersebut, menekankan pemahamannya bahwa esensi manusia adalah lebih kepada zat dan materinya. Manusia beraktivitas menggunakan organ, misalnya makan dengan tangan, berjalan dengan kaki, mendengar dengan telinga, dan lain-lain. Atas konsepsi pemikiran aliran serba zat, maka dalam pendidikan manusia ditekankan melalui proses mengalami atau praktek (psikomotorik). 
2. Aliran Serba Ruh

Dalam istilah yang lain aliran ini juga disebut dengan "aliran idealisme". Gagasan utama aliran pemikiran ini adalah memposisikan "Ruh" sebagai hakikat atas segala sesuatu yang ada di dunia ini, sebagaimana hakikat manusia adalah "Ruh". Ruh dalam bahasa universal diartikan juga sebagai jiwa, mental, atau rasio/akal. Oleh karenanya materi atau zat berupa jasmani atau tubuh manusia merupakan alat jiwa untuk melaksanakan tujuan, keinginan dan dorongan jiwa (rohani, spirit, ratio) manusia.

Aliran pemikiran ini sampai pada kesimpulan bahwa yang menggerakkan tubuh atau jasmani itu adalah ruh atau jiwa. Tanpa ruh atau jiwa maka niscaya jasmani berupa raga atau fisik manusia akan mati, atau tanpa berdaya sama sekali. Untuk itu dalam pendidikan manusia, tidak semata aspek pengalaman yang diutamakan, akan tetapi faktor dalam diri yakni potensi bawaan seperti intelegensi, rasio, kemauan dan perasaan, juga termasuk bagian yang harus diberikan perhatian.

3. Aliran Dualisme

Konsep utama aliran ini adalah menganggap bahwa hakikat manusia terdiri dari dua substansi, yaitu berupa jasmani dan rohani. Aliran dualisme melihat realita semesta sebagai sintesa kedua kategori yaitu animate dan inanimate (makhluk hidup dan benda mati). Begitu Pula adanya manusia sebagai kesatuan rohani dan jasmani atau jiwa dan raga.

Aliran ini mendeskripsikan sebuah contoh persoalan manakala timbul pertanyaan dimanakah letak mind (jiwa, ratio) dalam diri manusia. Kebanyakan orang dengan menggunakan logika sederhana akan menjawab bahwa ratio itu terletak pada otak. Namun kemudian timbul permasalahan yang juga berdasar dari berpikir logis, bagaimana mungkin suatu entitas immaterial entity (suatu yang non-material) yang tidak membutuhkan ruang, dapat ditempatkan pada suatu materi (tubuh jasmani) yang berada pada ruang wadah tertentu (Anim, 2014).

Sesuai gagasan tersebut, aliran dualisme meyakini bahwa sesungguhnya manusia tidak dapat dipisahkan antara zat/raga dan ruh/jiwa karena pada hakikatnya keduanya tidak dapat dipisahkan satu sama lain. Kedua unsur tersebut masing-masing memiliki peranan yang penting dimana raga tanpa ruh ia akan mati dan ruh tanpa raga ia tidak dapat berbuat apa-apa. Oleh karena itu dalam dunia pendidikan, kedua unsur ini harus diberikan perhatian 
sebagai aspek ilmu untuk dikaji karena keduanya sangat penting untuk dipahami.

\section{Aliran Eksistensialisme}

Aliran eksistensialisme dalam ranah filsafat modern mengungkapkan bahwa hakikat manusia merupakan eksistensi atau perwujudan sesungguhnya dari manusia. Atau dengan pendapat bahwa hakikat manusia adalah apa yang menguasai secara menyeluruh yakni manusia dipandang sebagai serba zat, serba ruh atau dualisme dari kedua aliran itu.

Sedangkan menurut Al-Ghazzali, manusia memiliki tiga sumber pengetahuan, yaitu panca-indera, otak, dan Al-'Aql. Panca-indera dan otak diciptakan Tuhan untuk manusia dan hewan, tetapi Al-'Aql adalah ciptaan Tuhan yang sengaja diciptakanNya dalam diri manusia, yang membedakan manusia dari binatang (Umaruddin 1995:18-14 dalam Hidayat, 2016). Panca-indera memiliki daya pendengaran, daya peraba, daya pengecap, daya penglihatan, dan daya penciuman yang memungkinkan manusia memperoleh pengetahuan. Otak memiliki daya imajinasi, daya refleksi, daya rekoleksi, daya memori, dan daya akal sehat yang memungkinkan manusia memperoleh pengetahuan darinya. Sedangkan Al-'Aql memiliki daya membangun generalisasi dan daya membangun konsep-konsep, daya mengetahui kebenaran yang abstrak, dan daya mengetahui kebenaran yang self-evident (kebenaran matematis bahwa $1+1=1$ ), daya mengetahui hal-hal ruhaniah yang tak terhingga, serta daya memahami hakikat segala sesuatu, yang memungkinkan manusia memperoleh pengetahuan darinya (Umaruddin 1995:18-14 dalam Hidayat, 2016).

\section{b Hakikat Alam Semesta}

Para ilmuwan dari berbagai belahan bumi telah melakukan penelitian tentang alam semesta ini. Oleh Morley dan Michelson pada tahun 1905 telah melakukan penelitian yang kemudian mendorong Einstein melahirkan teori "Relativitasnya". Demikian juga Gamow pada tahun 1951, yang kemudian mengungkapkan bahwa suatu ketika seluruh alam ini akan semakin mengecil volumenya akibat ledakan yang dahsyat dari suatu titik dan mengembang. Hubble juga berpendapat yang sama bahwa ledakan dahsyat yang memancarkan radiasi sebagai akibat adanya kilatan dari ledakan tersebut. Sebagai akibat dari ledakan itu, ekspansi dari radiasi berakibat alam semesta 
mendingin yang mengubah radiasi menjadi gelombang mikro (Anas Salahudin, 1011 dalam Alimatus, 2020).

Menurut Abud (1976) bahwa"karena keteraturan alam, saling kait mengait dan saling melengkapi antara unsur yang satu dengan unsur lainnya, mengharuskan manusia bekerja sama untuk mewujudkan kehidupan yang sifatnya umum dan mewujudkan manusia yang baik dengan sifatnya yang khusus. Untuk dapat mewujudkan kehidupan yang baik manusia berkewajiban mempelajari, memahami dan mengenal hukum keteraturan alam ini (Maragustam, 1014 dalam Alimatus, 2020)

Menurut Al-Jurjani dalam kitab Al-Ta`Arifat, terma "Alam" segala bahasa berarti segala hal yang menjadi tanda bagi suatu perkara sehingga dapat dikenali, sedangkan secara terminologi berarti segala sesuatu yang maulud (maufudat) selain Allah, yang dengan ini Allah dapat dikenali, baik dari segi nama maupun dari sifatnya. Segala sesuatu selain Allah, itulah alam secara sederhana. Pengertian ini merupakan pengertian teologis, dalam arti berdasarkan yang dikemukakan oleh para teologi Islam. Adapun secara filosofis, "alam" adalah kumpulan faubar (substansi) yang tersusun secara materi ( maddad) dan bentuk ( shurah) yang ada dilangit dan di bumi. Segala sesuatu yang ada di langit dan di bumi, itulah alam berdasarkan rumusan filsafat. Alam dalam pengertian ini merupakan alam semesta atau jagad raya, yang dalam bahasa Inggris disebut universe.

Al Quran tidak secara khusus mengungkapkan alam semesta dengan tema "alam" dalam bentuk tunggal, tapi menyebutnya dalam bentuk jamak, yaitu 'alami yang diungkapkan sebanyak 73 kali dalam Alqur’an. Menurut Muhammad Abduh, orang Arab sepakat bahwa kata 'alamin tidak digunakan untuk merujuk kepada segala sesuatu yang ada seperti alam batu, dan alam tanah, akan tetapi, mereka memakai 'alamin untuk merujuk kepada setiap makhluk tuhan yang berakal, atau mendekati sifat-sifat berakal, seperti alam manusia, alam hewan, dan alam tumbuhan. Dengan ini, Sirajuddin Zar menawarkan bahwa Alqur'an, untuk merujuk alam dalam pengertian alam semesta ( universe) itu, menggunakan kata al-samawat wa al-ardb wa ma bainahuma, yang disebut Alquran sebanyak 10 kali. Kata ini mengacu kepada dua alam, alam non fisik atau alam gaib, seperti alam malaikat, alam jin, dan alam ruh (Yuliana, 2020).

Kontek dalam mempermudah kajian, Abu Al-'Ainain menyebut alam semesta dalam filsafat dengan istilah al-kaun, yang berarti segala sesuatu yang di ciptakan, yang mencakup nama segala jenis makhluk, baik yang dapat dihitung 
maupun yang hanya dapat dideskripsikan saja. Al-kaun sebagai wujud makhluk Allah dapat dibagi dalam dua kategori; Alam Al-Syahadad yang dapat dikenali melalui panca indera seperti langit dan bumi, dan Alam Al-Gaib yang hanya dapat dikenali melalui Wahyu Ilahi, seperti alam malaikat, dan alam jin. Menurut Mulyadhi Kartanegara, alam semesta dalam tinjauan filsafat Islam diciptakan melalui kehendak bebas Tuhan, bukan melalui keniscayaan. Alam semesta diciptakan secara sengaja dan terencana, bukan secara kebetulan. Alam semesta tidak bersifat abadi, tetapi tercipta dalam waktu dengan sebutan titik awal. Alam diciptakan dari tiada meskipun ketiadaan ini tidak harus selalu dipahami dalam arti ketiadaan yang mutlak, tetapi ada sebagai kemungkinan (Toto Suharto, 1006 dalam Alimatus, 2020).

\section{c. Hakikat Masyarakat}

Konteks Negara, masyarakat sebagai kumpulan individu-individu dapat dengan muda disatukan dalam suatu konsensus hukum positif, akan tetapi dalam realitas kehidupan interaksi dapat menimbulkan problem manakalah kumpulan individu-individu terdiri dari keragaman karakter sosial serta latar belakang budaya yang berbeda-beda, kenyataan ini sering terjadi pada masyarakat yang bersifat majemuk atau masyarakat heterogen.

J. S Furnivall (1967) seorang sarjana bangsa Belanda yang banyak menulis tentang indonesia, memberikan suatu gambaran tentang masyarakat majemuk ini, Furnivall mengatakan bahwa masyarakat majemuk adalah suatau masyarakat dimana sistem nilai yang dianut berbagai kesatuan sosial yang menjadi bagian-bagiannya adalah sedemikian rupa atau beragam sehingga para individu masyarakat kurang memiliki loyalitas terhadap masyarakat dalam konteks keseluruhan, kurang memiliki homogenitas kebudayaan atau bahkan kurang memiliki dasar-dasar untuk saling memahami satu sama lain. Suatu masyarakat adalah bersifat majemuk sejauh masyarakat tersebut secara struktural memiliki sub-sub kebudayaan yang bersifat berbeda satu sama lain. Masyarakat yang demikian ditandai oleh kurang berkembangnya sistem nilai atau konsensus yang disepakati oleh seluruh masyarakat karena berkembangnya sistem nilai dari kesatuan sosial yang menjadi bagian-bagiannya dengan pengertian para anggotanya masing-masing secara tegar dalam bentuknya yang relatifmurni, serta sering timbulnya konflik-konflik sosial, atau setidak-tidaknya oleh kurangnya integrasi dan saling ketergantungan di antara kesatuan-kesatuan sosial yang menjadi bagian-bagiannya (Middya, 2017). 
Mengulas lebih jauh tentang masyarakat, maka kita mencoba memulai menelusuri asal kata "masyarakat" dalam dua pengertian. Dalam Bahasa Arab masyarakat berasal dari kata musyarak yang juga bermakna ikut serta atau berpartisipasi, sedangkan dalam bahasa Inggris masyarakat disebut Society yang juga dapat bermakna perkumpulan, perhimpunan, lembaga, komunitas, dan lain-lain. Dengan demikian masyarakat dapat didefinisikan sebagai sekumpulan manusia yang berinteraksi dan terjalin erat karena sistem tertentu, tradisi tertentu, konvensi dan hukum tertentu yang sama dan hidup bersama dalam suatu hubungan social. Masyarakat juga dapat diartikan sebagai suatu perwujudan interaksi kehidupan bersama manusia, atau suatu kelompok manusia yang hidup bersama dalam suatu wilayah dengan tata cara berfikir dan bertindak relatif. Mereka mempunyai kesamaan budaya, wilayah, dan identitas. Dalam masyarakat berlangsung proses kehidupan sosial, proses antar hubungan dan antaraksi. Dengan demikian masyarakat dapat diartikan sebagai wadah atau medan tempat berlangsungnya antar aksi warga masyarakat"itu.

Secara umum masyarakat adalah sekumpulan manusia yang bertempat tinggal dalam suatu wilayah dan saling berinteraksi dengan sesama untuk mencapai tujuan. Anggota masyarakat terdiri dari berbagai ragam pendidikan, profesi, keahlian, suku, bangsa, agama, maupun lapisan sosial sehingga menjadi masyarakat yang majemuk. Secara langsung dan tidak langsung setiap anggota masyarakat tersebut telah menjalin komunikasi mengadakan kerja sama dan saling mempengaruhi dalam rangka mencapai tujuan (Kees, 1995).

Menurut Syaikh Taqyuddin An-Nabhani, sekelompok manusia dapat dikatakan sebagai sebuah masyarakat apabila memiliki pemikiran, perasaan, serta sistem/aturan yang sama. Dengan kesamaan-kesamaan tersebut, manusia kemudian berinteraksi sesama mereka berdasarkan kemaslahatan. Menurut Plato tidak membedakan antara pengertian Negara dan masyarakat. Negara tersusun dari individu-individu dan tidak disebutkan kesatuan-kesatuan lebih besar. Negara sama dengan masyarakat. Menurut Aristoteles membuat perbedaan antara Negara dan masyarakat. Negara adalah kumpulan dari unitunit kemasyarakatan, seangkan masyarakat terdiri dari keluarga-keluarga, Adapun menurut Comte memperluas analisis-analisis masyarakat, dengan menganut suatu pandangan tentang masyarakat sebagai lebih dari suatu gerombolan individu-individu (Loren Bagus, 2000 dalam Alimatus, 2020).

Islam berdasarkan alqur'an membahas masyarakat dalam beberapa istilah, diantaranya menggunakan kata Ummah, Qaum, Qabilah, Sya 'b, Tha'Ifah atau Jama`ah. Namun dari sekian banyak istilah yang digunakan alqur’an lebih 
banyak menggunakan istilah ummah. Al qur'an menyebut kata ummah sebanyak 51 kali, sedangkan kata umam sebanyak 13 kali. Pada tulisan ini lebih menfokuskan pembahasan pada kata ummah dengan arti masyarakat. Menurut ahli Syari ati (1989) makna generik ummah memiliki keunggulan.

Kata ummah manusia yang dipakai oleh al quran tidaklah berasal dari kata alif, mim, mim tetapi kata tersebut merupakan pinjaman dari bahasa Ibrani yaitu umma, atau dari bahasa arab yaitu ummata (Gibb and Kramers,1960). Bagaimanapun kata umma baik dalam arti apapun mempunyai akar kata alif, mim, mim, dan dari kata umam dan umm. Menurut John Penrice (1971) bahwa kata ummata berarti penduduk, bangsa, ras, kelompok, ketentuan, istilah tertentu waktu dan agama tertentu. Muhammad Ismail Ibrahim mengartikannya dengan kelompok manusia, muallim, seorang yang baik pada semua seginya, agama, tempat dan waktu (Alimatus, 2020).

\subsection{Contoh Berpikir Holistik}

Definisi berpikir holistik telah diuraikan pada sub pembahasan sebelumnya dimana berpikir holistik berarti berpikir sehat atau dalam dunia pendidikan kita kenal dengan istilah pendidikan holistik yang didefinisikan sebagai sebuah metode pendidikan atau pembelajaran yang membangun manusia secara utuh dengan menggali semua potensi yang dimiliki oleh setiap individu yang mencakup potensi sosial, potensi emosi, potensi intelektual, potensi fisik, potensi moral, potensi kreatifitas maupun potensi spiritual, semua itu akan bermuara terbentuknya manusia holistik dimana manusia holistik adalah manusia yang mampu mengembangkan dirinya (Jujun, 2005).

Menelisik pemikiran di atas, kita menyadari bahwa berpikir holistik, tidak terbatas hanya pada dunia pendidikan atau dalam rana pembelajaran formal melalui sivitas akademika pada semua level tingkatan, akan tetapi kata "holistik" telah menjadi sebuah kata yang bermakna penting dan merambah ke semua dimensi ilmu yang dipelajari oleh manusia modern saat ini, setidak tidaknya ada beberapa contoh berpikir holistik yang sedikit banyaknya akan membuka cakrawala berpikir kita untuk mengkonsepsikan hubungan antar manusia dan manusia dengan lingkungannya dalam konteks kepemimpinan holistik, pendidikan sebagai ujung tombak untuk berpikir kritis, dan lain-lain. 
1. Kepemimpinan Holistik menurut Jennie M. Xue

Kepemimpinan holistik merupakan model kepemimpinan dimana seorang pemimpin tidak semata-mata memandang dirinya sebagai "pemimpin" namun juga memiliki kedalaman pengetahuan dan pemahaman tentang siapa yang dipimpinnya. Pemahaman ini dalam konteks "habitat" atau ruang bergerak yang selanjutnya dikorelasikan pada tiga faktor, yaitu pemimpin, yang dipimpin, dan lingkungan.

Kepemimpinan holistik yang ideal merupakan perjalan yang melibatkan semua unsur dalam suatu transformasi secara menyeluruh (komprehensif), mencakup unsur fisik, psikis, dan spiritual dalam berbagai aktivitas kepemimpinan, termasuk dalam hal penyelesaian tugas, penyelenggaraan fungsi, pengambilan keputusan, dan dalam berkomunikasi.

Menurut riset psikologi kepemimpinan, kepemimpinan holistik sangat dipengaruhi oleh kualitas kerjasama antara keduanya, yaitu pemimpin dan yang dipimpin dengan senantiasa mengasah empat hal antara lain ; analitis, konseptual, emosional, dan spiritual, dengan lima model berpikir:

1 Menjadi tuan bagi diri sendiri (You are your own master). Apa yang kita pikirkan, rasakan dan perbuat merupakan tanggung jawab kita sendiri. Jangan menyalahkan orang lain karena perbuatan kita sendiri (Don't blame others). Perhatikan setiap kali pikiran dan perasaan muncul. Bangun ke-pekaan akan apa yang telah, sedang, dan akan terjadi. Skill ini penting dalam memimpin.

2 Mengasah kepemimpin-an pemikiran (Thought leader-ship) hanya dapat diasah dengan mengolah pikiran secara kritis. Bisa dimulai dengan menulis-kan poin-poin sehingga struktur dan konsep semakin jelas da-lam setiap aktivitas. Semua ada makna dan tujuan. Ini perlu di-jelaskan kepada subordinatif se-hingga kekompakan dapat di-bangun. Saling mengingatkan sehingga perjalanan bisa berja-lan seiring.

3 Menjadi coach bagi diri sendiri dan orang lain. Gol perlu ditangani dengan konfiden dan teliti. Dengan kata lain, perlu kesungguhan agar deadline da-pat dicapai. Mencapai gol tepat waktu merupakan tugas seo-rang coach yang utama. Ketika Anda menjadi coach bagi diri sendiri, perspektif holistik ob-jektif merupakan keharusan, sehingga mau tidak mau ini akan semakin terasa. 
4 Menerapkan hidup sehat berimbang. Seorang pe-mimpin holistik idealnya hidup sehat berimbang antara fisik dan psi-kis. Ini penting bagi diri sendiri dan mereka yang dipimpin ka-rena memberi rasa yakin bahwa setiap keputusan diolah secara optimal. Kesehatan psikis ter-masuk keyakinan akan diri, ke-mampuan diri, dan kemampuan orang lain sehingga tercipta emosi positif.

5. Mengenali lingkungan dalam arti mengenali domain lingkungan dari yang terdekat hingga yang ter-jauh. Dari lingkungan tim, grup, divisi, departemen, korporasi, asosiasi korporasi, kota, nega-ra, dan dunia. Keputusan perlu diambil berdasarkan konteks-nya, sebagaimana setiap kegiat-an. Sesuatu dan seseorang tidak pernah terlepas dari konteks-nya. Ini perlu selalu diingat, ka-rena setiap kesuksesan dan ke-gagalan erat hubungannya de-ngan kondisi lingkungan yang bertingkat tersebut (Jennie M. Xue, 2017).

Contoh pemimpin yang berpiki holistik sebagaimana dikemukakan oleh Jennie, sejalan dengan beberapa teori kepemimpinan holistik, diantaranya adalah teori yang dikemukakan James L. C. Taggart bahwa Pemimpin Holistik dapat memahami dan memiliki perhatian terhadap kebutuhan untuk mengembangkan tiga aspek yang meliputi jiwa, pikiran dan tubuh (James L. C. Taggart, 1011 dalam Amin, 1014). Atau model kepemimpinan holistik ala Haryoko yang menawarkan sebuah warnah baru model kepemimpinan dengan sentuhan penyelarasan aspek-aspek spiritual dalam proses pengelolaan/manajemen organisasi yang diyakini dapat membawa pengaruh positif terhadap hubungan timbal balik antara pemimpin dan anggota yang pada akhirnya akan meningkatkan kinerja dan output yang dicapai (Amin, 2014).

\section{Berpikir Kritis Melalui Pendekatan Saintifik dalam Proses Pembelajaran.}

Pembahasan menurut pandangan pada spek teori, Daryanto mengemukakan bahwa pendekatan saintifik adalah proses pembelajaran yang dirancang sedemikian rupa agar siswa secara aktif mengkonstruksi konsep, hukum atau prinsip melalui tahapan tahapan mengamati (mengidentifikasi/menemukan masalah), merumuskan masalah, mengajukan atau merumuskan hipotesis, mengumpulkan data dengan teknik, menganalisis data, menarik kesimpulan dan mengkomunikasikan konsep, hukum atau prinsip yang ditemukan. Artinya pendekatan saintifik dapat memberikan pemahaman kepada siswa dalam 
mengenal, memahami berbagai materi dengan menggunakan pendekatan saintifik bahwa informasi bisa didapatkan dan berasal dari mana saja, kapan saja, dan tidak tergantung dari guru (Daryanto, 2014 dalam Liana, 2020).

Menurut Machin, Pendekatan saintifik memiliki lima fase yaitu, mengamati, menanya, mengumpulkan informasi, menalar dan mengkomunikasikan. Dari lima fase tersebut dapat mengembangkan berbagai skill seperti keterampilan berpikir kritis (critical thinking skill), keterampilan berkomunikasi (communication skill), keterampilan melakukan kerja sama dan penyelidikan (research and collaboration skill) dan perilaku berkarakter, karena pengalaman belajar yang diberikan dapat memenuhi tujuan pendidikan dan bermanfaat bagi pemecahan masalah dan kehidupan nyata (Machin, A, 2014 dalam Liana, 2020).

Lalu bagaimana mengimplementasikan berpikir kritis melalui pendekatan saintifik dalam lima fase, hubungannya dengan berpikir holistik dalam rana pendidikan.

a. Melakukan pemantauan dan observasi (mengamati), menurut Majid, A dan C. Rochman, 2014 dalam Liana, 2020, beberapa prinsip yang harus diperhatikan oleh guru dan siswa selama observasi pembelajaran yakni:

1 Cermat, objektif, dan jujur serta fokus pada objek yang diobservasi untuk kepentingan pembelajaran.

2 Banyak atau sedikit serta homogenitas atau heterogenitas subjek, objek, atau situasi yang diobservasi.

3 Guru dan siswa perlu memahami apa yang hendak dicatat, direkam, dan sejenisnya, serta bagaimana membuat catatan atas perolehan observasi.

4 Karena metode observasi merupakan jalan untuk menemukan fakta, maka Daryanto menawarkan kerangka pemikiran kegiatan mengamati dalam pembelajaran dengan langkah-langkah sebagai berikut (Daryanto, 2014 dalam Liana, 2020) :

5 Menentukan objek apa yang akan di amati

6 Membuat pedoman observasi sesuai dengan lingkup objek yang akan diobservasi oleh siswa

7 Menentukan secara jelas data-data apa yang perlu diobservasi, baik primer maupun sekunder

8 Menentukan di mana tempat objek yang akan diobservasi 
9 Menentukan secara jelas bagaimana observasi akan dilakukan untuk mengumpulkan data agar berjalan mudah dan lancer

10 Menentukan cara dan melakukan pencatatan atas hasil observasi, seperti menggunakan buku catatan, kamera, tape recorder, video perekam, dan alat-alat tulis lainnya.

b. Mengajukan Pertanyaan (menanya), menurut Hosnan. 2014 dalam Liana, 2020, beberapa hal yang harus diperhatikan dalam penggunaan pertanyaan antara lain:

1 Materi harus menarik dan menantang serta memiliki nilai aplikasi tinggi.

2 Pertanyaan bervariasi, meliputi pertanyaan tertutup (pertanyaan yang jawabannya hanya ada satu kemungkinan) dan pertanyaan terbuka (pertanyaan dengan banyak kemungkinan jawaban).

3 Jawaban pertanyaan itu diperoleh dari penyempurnaan jawaban-jawaban siswa.

4 Dilakukan dengan teknik bertanya yang baik.

Adapun fungsi bertanya yang dilaksanakan dalam proses pembelajaran menurut Majid, A dan C. Rochman, 2014 dalam Liana, 2020, adalah:

1 Membangkitkan rasa ingin tahu, minat, dan perhatian siswa tentang suatu tema atau topik pembelajaran.

2 Mendorong dan menginspirasi siswa untuk aktif belajar, serta mengembangkan pernyataan dari dan untuk dirinya sendiri.

3 Mendiagnosis kesulitan belajar siswa sekaligus menyampaikan rancangan untuk mencari solusinya.

4 Menstrukturkan tugas-tugas dan memberikan kesempatan kepada siswa untuk menunjukkan sikap, keterampilan, dan pemahamannya atas substansi pembelajaran yang diberikan.

5 Membangkitkan keterampilan siswa dalam berbicara, mengajukan pertanyaan, dan memberi jawaban secara logis, sistematis, dan menggunakan bahasa yang baik dan benar.

6 Mendorong partisipasi siswa dalam berdiskusi, berargumen, mengembangkan kemampuan berpikir, dan menarik kesimpulan. 
7 Membangun sikap keterbukaan untuk saling memberi dan menerima pendapat atau gagasan, memperkaya kosa kata, serta mengembangkan toleransi sosial dalam hidup berkelompok.

8 Membiasakan siswa berpikir spontan dan cepat, serta sigap dalam merespon persoalan yang tiba-tiba muncul.

9 Melatih merespon persoalan dalam berbicara dan membangkitkan kemampuan berempati satu sama lain.

c. Melakukan Eksperimen / Percobaan (Memperoleh Informasi), Hosnan, 2014 dalam Liana, 2020 mengemukakan bahwa dalam penggunaan metode eksperimen harus memperhatikan hal-hal sebagai berikut:

1 Eksperimen, setiap siswa harus mengadakan percobaan, maka jumlah dan bahan atau materi percobaan harus cukup bagi setiap siswa.

2 Eksperimen, siswa perlu teliti dan konsentrasi dalam mengamati percobaan, maka perlu adanya waktu yang cukup lama sehingga mereka menemukan pembuktian kebenaran dari teori yang dipelajari itu.

3 Siswa dalam eksperimen adalah sedang belajar dan berlatih, maka perlu diberikan petunjuk yang jelas.

4 Tidak semua masalah bisa dieksperimenkan.

d. Mengasosiasikan (menalar)

Kemampuan mengolah informasi melalui penalaran dan berpikir rasional merupakan kompetensi penting yang harus dimiliki oleh siswa. Informasi yang diperoleh dari pengamatan atau percobaan yang telah dilakukannya harus diproses untuk menemukan keterkaitan satu informasi dengan informasi yang lainnya, menemukan pola dari keterkaitan informasi, dan mengambil berbagai kesimpulan dari pola yang ditentukan. Menalar adalah aktivitas mental khusus dalam melakukan inferensi. Inferensi adalah menarik kesimpulan berdasarkan pendapat, data, fakta atau informasi (Liana, 2020).

Kegiatan menyimpulkan dalam pembelajaran dengan pendekatan saintifik merupakan kelanjutan dari kegiatan mengolah data atau informasi. Setelah menemukan keterkaitan antara informasi dan menemukan berbagai pola dari keterkaitan tersebut, selanjutnya secara bersama-sama dalam satu kesatuan kelompok, atau secara individu membuat kesimpulan (Hosnan, 2014 dalam Liana, 2020). 
Permendikbud nomor 81a menyebutkan bahwa kegiatan menalar adalah memproses informasi yang sudah dikumpulkan baik terbatas dari hasil kegiatan mengumpulkan/eksperimen maupun hasil dari kegiatan mengamati dan kegiatan mengumpulkan informasi. Adapun kompetensi yang diharapkan adalah mengembangkan sikap jujur, teliti, disiplin, taat aturan, kerja keras, kemampuan menerapkan prosedur dan kemampuan berpikir induktif serta deduktif dalam menyimpulkan informasi (Daryanto, 2014 dalam Liana, 2020).

e. Membantu atau Mengembangkan Jaringan dan Berkomunikasi (Mengkomunikasikan)

Kemampuan untuk membangun jaringan dan berkomunikasi perlu dimiliki oleh siswa karena kompetensi tersebut sama pentingnya dengan pengetahuan, keterampilan dan pengalaman. Bekerja sama dalam kelompok merupakan salah satu cara membentuk kemampuan siswa untuk dapat membangun jaringan dan berkomunikasi. Keterampilan intrapersonal, keterampilan interpersonal dan keterampilan organisasional merupakan soft skills yang sangat dibutuhkan untuk membangun jaringan agar dapat sukses dalam kehidupan (Sani R. A, 2014 dalam Liana, 2020)

Permendikbud nomor 81a juga menyebutkan bahwa kegiatan mengkomunikasikan adalah menyampaikan hasil pengamatan, kesimpulan berdasarkan hasil analisis, secara lisan, tertulis, atau media lainnya. Adapun kompetensi yang diharapkan dalam kegiatan ini adalah mengembangkan sikap jujur, teliti, toleransi, kemampuan berpikir sistematis, mengungkapkan pendapat dengan singkat dan jelas, dan mengembangkan kemampuan berbahasa yang baik dan benar (Daryanto, 2014 dalam Liana, 2020). 


\section{Bab VII \\ Idealisme Filsafat terhadap Metode Kualitatif dan Kuantitatif}

\subsection{Pendahuluan}

Berbagai asumsi dapat dikemukakan dalam suatu anlisis. Asumsi lahir dari berbagai analisis, temuan, fakta-fakta dan realita baik yang ada kaitannya dengan fenomena alam, pengalaman hidup, maupun kombinasi antara keduanya, termasuk dinamika yang terjadi dalam kehidupan sosial dan masyarakat. Asumsi dapat berhubungan dengan syarat-syarat, kondisi-kondisi dan tujuan. Asumsi memberikan hakekat, bentuk dan arah argumentasi. Asumsi juga bermaksud membatasi masalah. Setiap agumentasi yang mendapat pengakuan melalui kesimpulan dalam bidang ilmu di dalamnya tersirat suatu anggapan dasar tertentu yang menopang kekuatan mengambil kesimpulan atau judgmen tertentu.

Pandangan dalam dinamika ekonomi menyatakan bahwa, jika faktor penawaran naik dianggap tidak ada atau tidak berpengaruh terhadap harga, bermakna bahwa asumsi bisa dipandang sebagai syarat berlakunya suatu kesimpulan (atau kondisi tertentu), sehingga asumsi merupakan hal yang sangat penting untuk dipahami, mengingat yang tidak selalu terhadap stiap pernyataan atau 
kesimpulan ilmiah untuk menyatakan dengan eksplisit mengenai asumsi. Namun dalam penulisan karya ilmiah sebaiknya seperti skripsi, tesis hendaknya dinyatakan asumsi-asumsi tersebut secara eksplisit, agar setiap pembacanya menperoleh gambaran atas asumsi tersebut dan dapat melakukan resensi atas asumsi yang dipahaminya untuk pengembangan suatu ilmu (Eduardus, 2015).

Umumnya, para filosof memahami bahwa dalam berbagai pandangan terhadap suatu objek terdapat ketentuan, norma-norma, kebiasaan-kebiasaan yang terpelihara dan diakui atau bahkan menjadi sebuah hukum sebab-akibat (kausalitas) sebagai hukum atau suatu yang terjadi sesuai dengan sunnah yang ada yang mengatur alam semesta. Semua kejadian yang berkaitan dengan alam semesta adalah seperti apa adanya sesuai sunnahnya. Orang awam juga menerima dengan berbagai pandangannya sesuai dengan cakrawala beripikir yang dimilikinya bahwa fenomena yang terjadi di alam semesta ini sesuai dengan hukum-hukumnya. Sesuai dengan pandangan tersebut membantu dan memudahkan kita bisa melihat fenomena yang menunjukkan bekerjanya hukum kausalitas. Misalnya, kita menjemur pakaian basah menggunakan panas matahari. Kita yakin bahwa pakaian basah tersebut menjadi kering disebabkan oleh panas matahari. Panas matahari adalah sebab, sementara, keringnya pakaian adalah akibat, sehingga para filosof menggunakan hukum kausalitas untuk membuktikan eksistensi adanya yang mengatur alam semesta ini. Konsep ketuhanan atau eksistensi Tuhan atau pembuktian eksistensi Tuhan yang Maha mengatur (Angel, 2015)

\subsubsection{Pengertian-pengertian dalam Metode Analisis}

\section{Konsep}

Konsep adalah bentuk analisis dengan cara menggambarkan secara abstrak tentang kejadian, keadaan, dalam suatu kelompok atau individu. Terdapat dua macam konsep:

1. Konsep yang berkaitan dengan fakta yang ada hubungannya dengan bendabenda yan dapat dilihat dan diraba. Misalnya konsep tentang kursi, meja, panic, kacamata, buku, dan benda lainnya.

2. Konsep yang berkaitan dengan hal-hal yang abstrak, yang tidak bisa dilihat dan diraba secara fisik, namun dapat dirasakan akan adanya objek tersebut, 
seperti angin, suara, cinta, indah, benci dan lainnya sebagai akibat dari penggunaan panca indera atau akibat dari yang kita rasakan.

\section{Proposisi}

Proposisi adalah hubungan atau korelasi yang logis dan rasional antara dua konsep atau lebih dalam bentuk kalimat pernyataan. Ada dua tipe proposisi yaitu: (1) Aksioma atau postulat dan (2) Teorema.

Istilah proposisi konstruksi merupakan sebuah teori yang terbentuk dari proposisi, dan proposisi merupakan suatu pernyataan mengenai satu atau lebih konsep atau variabel. Proposisi yang menyatakan variabel tunggal disebut proposisi univariat dan jika menghubungkan dua variabel disebut proposisi divariat sedang bila proposisi itu menghubungkan lebih dari dua variabel disebut proposisi multivariat. Secara prinsip proposisi adalah sebuah asumsi yang biasanya dipadankan dengan istilah anggapan dasar. Asumsi adalah sesuatu yang dianggap tidak berpengaruh atau dianggap konstan. Asumsi dapat berkaitan dengan syarat-syarat, kondisi-kondisi dan tujuan. Asumsi memberikan hakekat, bentuk dan arah argumentasi(Bagir, 2006).

\section{Variabel}

Kata "variabel" berasal dari bahasa Inggris variable dengan arti "ubahan" atau dalam makna lain dikatakan faktor tak tetap, atau gejala yang dapat diubah-ubah atas dinamika yang ada. Variabel adalah sesuatu yang mempunyai vartiasi nilai atau gejala yang bervariasi, sedangkan gejala adalah objek penelitian, jadi variabel adalah objek penelitian yang bervariasi.

Variabel terdiri dari dua kategori, yaitu kuantitatif dan kualitatif. Contoh kuantitatif seperti usia, tinggi badan, jam kerja, luas kota dan lain-lain. Kuantitatif dipandang sebagai hal yang dapat diukur dan umumnya memiliki nilai dalam bentuk besaran, sedangkan contoh kualitatif adalah kepandaian, kemakmuran, kemiskinan, keindahan, kecantikan, kesenangan, kebahagiaan, kesedihan, kesengsaraan, kedukaan, dan lain sebagainya atau kualitatif adalah sesuatu yang berkaitan dengan hal-hal yang hanya dapat dirasakan, meskipun model-model dalam analisis ini telah dimodifikasi dan telah bermetamorfosis ke dalam model kuantitatif.

\section{Teori}


Kata teori memiliki arti yang berbeda-beda pada bidang-bidang kajian pengetahuan. Teori juga berbeda tergantung pada metodologi dan konteks diskusi yang dibahas sbagai topik kajian. Secara umum, teori merupakan analisis hubungan antara fakta yang satu dengan fakta yang lain pada sekumpulan fakta-fakta yang telah terjadi.

Teori adalah sekumpulan atau seperangkat konstruk (konsep) yang memiliki korelasi dalam hal pemahaman, makna, definisi dan proposisi yang berfungsi untuk melihat fenomena secara sistematik dan runtut melalui spesifikasi hubungan antar variabel, sehingga dapat berguna untuk menjelaskan dan meramalkan fenomena.

Teori mengandung tiga hal yaitu: (1) Serangkaian proposisi antar konsep yang saling berhubungan; (2) Menerangkan secara sistematis suatu fenomena dengan cara menentukan hubungan antar konsep dan (3) Menerangkan fenomena dengan menentukan konsep mana yang berhubungan dan bentuk hubungannya (Blalock, 1972; 1968).

\section{Asumsi}

Asumsi adalah landasan berpikir yang dianggap benar. Peneliti harus dapat memberikan sederet asumsi tentang kedudukan atau posisi masalahnya, karena asumsi atau anggapan dasar tersebut menjadi patron teori di dalam penyusunan pelaporan hasil penelitian yang akan disampaikan.

Asumsi dapat berupa teori, pemikiran atas penelitian sendiri atau evidensievidensi. Apapun materinya, asumsi tersebut harus sudah merupakan sesuatu yang tidak perlu dipersoalkan atau dibuktikan lagi kebenarannya karena sudah menjadi kesepahaman yang diakui dan dapat diterima, seurang-kurangnya bagi masalah yang menjadi objek yang diteliti pada masa itu. Asumsi-asumsi dirumuskan sebagai landasan berpijak bagi hipotesis laporan atau hasil penelitian.

\section{Hipotesis}

Hipotesis adalah proposisi yang dinyatakan untuk dilakukan pengujian. Hipotesis dapat dipahami sebagai anggapa atau penjelasan sementara yang masih memerlukan pengujian di lapangan, jadi jika kita berpendapat bahwa terdapat hubungan antara konsep atau variabel $\mathrm{X}$ dengan variabel $\mathrm{Y}$, maka 
pertama dinyatakan sebagai hipotesis untuk kemudian menguji hipotesis tersebut di lapangan/laboratorium atau diteliti, apakah fakta lapangan atau laboratoroium menerima atau menolaknya. Adapun dasar hipotesis dapat diperoleh dari berbagai sumber misalnya dari pengamatan sehari-hari, dari hasil penelitian yang sudah ada, pengembangan dari hasil pemikiran ilmiah atau hasil dari analisis data lapangan, laboratorium, atau dari review teori (Chalmers, 1983).

Hipotesis adalah penjelasan sementara tentang suatu tingkah laku, gejala-gejala, atau kejadian tertentu yang telah terjadi atau akan terjadi, sehingga hipotesis merupakan rumusan jawaban sementara yang harus diuji kebenarannya dengan data yang dianalisis dalam kegiatan penelitian.

Fakta yang diperlukan untuk merumuskan hipotesis, yaitu; (1) Memperoleh sendiri dari sumber aslinya; (2) Menafsirkan dari sumber asli dan (3) Data yang diperoleh dengan jalan menyusunya dalam bentuk abstrak hasil penalaran abstrak. Hipotesis yang baik dapat dijadikan referensi atau petunjuk dalam melaksanakan penelitian. Ciri-ciri hipotesis yang baik yaitu; (1) mempunyai hubungan dengan bidang yang diteliti; (2) Bisa diuji kebenarannya dan (3) Rumusannya sederhana dan terbatas.

Beberapa istilah lainnya dalam suatu asumsi dan analisis dengan menerapkan metode ilmiah baik kuantitatif maupun kualitatif yang juga memiliki peran dan fungsi dalam mengungkapkan sesuatu hal, misalnya:

1. Generalisasi empiris merupakan pernyataan hubungan yang di dasarkan pada hasil penelitian lapangan (induksi). Generalisasi merupakan keumuman sifat atau pola yang disimpulkan dari penelitian atas fakta-fakta yang terdapat di lapangan.

2. Aksioma adalah proposisi yang kebenarannya mengacu pada proposisiproposisi lainnya, aksioma terkadang disebut teori deduktif, dengan konotasi matematis dan proposisi jenis ini biasanya mempunyai tingkat abstraksi yang tinggi, sandaran aksioma adalah rasional logis berdasarkan hukum berfikir yang benar

3. Postulat adalah proposisi yang punya makna hampir sama dengan aksioma namun kebenaran pernyataannya telah teruji secara empiris.

4. Teorema adalah proposisi yang didasarkan pada serangkaian aksioma atau postulat. 


\subsubsection{Pandangan Filsafat terhadap Pengembangan Metode Analisis}

Eksistensi hukum kausalitas ditolak oleh dua tokoh ternama, masing-masing mewakili kalangan Barat dan Timur. Dua tokoh tersebut adalah Al-Ghazali dan David Hume. Al-Ghazali adalah tokoh sentral berasal dari Timur di kalangan Muslim. Bahkan diberi gelar Hujjatul Islam. Dua di antara sekian banyak karyakaryanya Al-Ghazali berjudul Ihya Ulum al-Din dan Tahafut al-Falasifah. Dua judul buku inilah diketahui bahwa Al-Ghazali menolak dua puluh pendapat para filosof Muslim tentang berbagai persoalan, termasuk persoalan hukum kausalitas. David Hume adalah tokoh sentral mewakili kalangan Barat, beraliran empirisme yang berkembang di Eropa, tepatnya berasal dari Inggris. Dimasa era pencerahan (enlightenment) atau Aufklarung, David Hume dianggap sebagai tokoh yang membawa empirisme pada puncak kematangan. David Hume berimplikasi pada skeptisisme (paham yang mengatakan bahwa kita tidak bisa memperoleh kebenaran), bahkan muncul istilah nihilisme (paham yang mengatakan bahwa kebenaran itu tidak ada/nihil). Empirisme David Hume merupakan anti-tesis dari rasionalisme Rene Descartes (Anonim, 1983).

Al-Ghazali lebih pada menafikan hukum kausalitas untuk menjelaskan fenomena mukjizat nabi-nabi, maka David Hume menafikan hukum kausalitas atas dasar konsistensi terhadap empirisme. Empirisme adalah paham yang mengatakan bahwa satu-satunya instrumen untuk memperoleh pengetahuan adalah pengamatan. Pengetahuan tidak diperoleh selain melalui pengamatan. Ketika kita mengamati kertas yang terbakar saat tersulut nyala api, kita mendapatkan pengetahuan bahwa kertas itu terbakar dan kini berubah menjadi abu. Tetapi, melalui pengamatan itu, kita tidak mendapati bahwa api adalah sebab bagi terbakarnya kertas. Kita tidak pula mendapati bahwa terbakarnya kertas adalah akibat dari api. Konsep sebab dan akibat tidak bisa diamati, sehingga argumentasinya terlalu lemah jika kita mengatakan bahwa hukum kausalitas itu eksis (Angels, 2000).

Menafikan hukum kausalitas oleh kedua tokoh di atas memiliki implikasi pada ketidakpastian banyak hal. Tidak ada kepastian bahwa setiap air yang dipanaskan akan mendidih, pakaian basah yang diletakkan di bawah sinar matahari akan menjadi kering, kertas yang disentuh api akan terbakar, dan berbagai contoh lainnya. Semuanya tidak ada yang pasti, sehingga jika konsisten menafikan hukum kausalitas, kita tidak akan bisa mendapatkan pengetahuan. Kita hanya bisa melaporkan peristiwa-peristiwa yang sudah pernah disaksikan. 
Sulit bagi kita menerima pandangan Al-Ghazali dan David Hume ini. Mengapa? karena secara teoritis bisa saja kita mengikuti pandangan mereka, tetapi secara praktis tetap saja kita meyakini bahwa banyak peristiwa yang mengandung kepastian: air mendidih jika dipanaskan, pakaian basah akan kering jika dijemur di bawah terik matahari, api membakar kertas, batu akan jatuh ke bawah jika dilempar, bola akan bergerak jika ditendang (Faisal, 2004).

Al-Ghazali dan David Hume menganggap bahwa hukum kausalitas itu tidak lebih dari urutan peristiwa yang sering kita saksikan sehingga kita menganggap hukum kausalitas itu benar-benar eksis. Padahal tidak. Jika kita melihat pakaian yang kering setelah dijemur di bawah panas matahari, bukan berarti keringnya pakaian itu disebabkan oleh panas matahari. Kita hanya melihat urutan peristiwa, yakni pakaian yang basah diletakkan di bawah sinar matahari, setelah beberapa saat, pakaian basah itu menjadi kering. Kita tidak bisa membuktikan eksistensi hukum kausalitas, sehingga di masa depan kita hanya bisa menyaksikan peristiwa A mendahului peristiwa B, maka ketika di lain kesempatan kita menyaksikan peristiwa $\mathrm{A}$, otomatis kita mengharapkan munculnya peristiwa B. Kita tidak bisa mengatakan peristiwa A menjadi sebab bagi munculnya peristiwa B. Kita hanya menyaksikan urutan peristiwa yang biasa terjadi dari awal hingga akhir dari peristiwa ke peristiwa berikutnya (Gleik, 2006).

Pandangan Al-Ghazali dan David Hume mungkin terasa aneh. Bagi kita, sudah jelas bahwa penyebab kertas itu terbakar adalah api, karena api memiliki sifat membakar. Al-Ghazali menafikan eksistensi hukum kausalitas dengan tujuan agar bisa menjelaskan terjadinya mukjizat yang banyak dilakukan oleh nabinabi. Kisah Nabi Ibrahim yang tidak terbakar oleh api bisa dimengerti karena yang menyebabkan terbakar adalah bukan api, melainkan Allah. Jika api adalah sebab bagi kebakaran, maka sudah pasti Nabi Ibrahim AS hangus terbakar.

Para filosof Muslim yang menjunjung tinggi hukum kausalitas akan melakukan takwil terhadap kisah pembakaran Nabi Ibrahim itu, yakni bahwa kisah tersebut adalah ungkapan metaforis (kiasan) belaka, bukan dibakar dalam arti harfiah. Secara sederhana dalam pandangan masa kini, kita dapat saja menyatakan bahwa peristiwa yang terjadi di zaman Nabi Isa AS, Nabi Ibrahim AS dan Nabinabi lainnya adalah sebuah mukjizat yang berjalan dalam koridor di luar rasio dan logika manusia secara umum. Pandangan filsafat masa kini tentulah mengalami pergeseran mengikuti perkembangan yang ada saat ini, meskipun bahwa filsafat masa kini dilandasi oleh pandangan filsafat masa yang sudah lampu (Golshani, 2003). 


\subsection{Filsafat Kausalitas dan Metode Ilmiah}

Kausalitas merupakan prinsip sebab-akibat yang ilmunya dan pengetahuan yang secara otomatis bisa diketahui tanpa membutuhkan pengetahuan dan perantaraan ilmu yang lain. Setiap kejadian pada prinsipnya memperoleh kepastian dan keharusan serta kekhususan-kekhususan eksistensinya akibat sesuatu atau berbagai hal lain yang yang mendahuluinya. Kausalitas adalah legitimasi dari penerimaan hal-hal yang diterima tanpa ragu dan tidak memerlukan sanggahan. Keharusan dan keaslian sistem kausal merupakan bagian dari ilmu manusia yang telah dikenal bersama dan tidak diliputi keraguan apapun (Goode, 1952).

Kausalitas dibangun oleh hanya dua aspek, yakni antara suatu kejadian (sebab) dan kejadian kedua (akibat atau dampak). Kejadian kedua dipahami sebagai konsekuensi dari kejadian pertama. Kausalitas merupakan asumsi dasar dari ilmu sains. Metode ilmiah, umumnya ilmuwan merancang eksperimen untuk menentukan kausalitas dari kehidupan nyata. Tertanam dalam metode ilmiah adalah hipotesis tentang hubungan sebab dan akibat atau hubungan kausal, karena tujuan dari metode ilmiah adalah menguji hipotesis yang objek kajian.

Memahami kausalitas (hubungan sebab-akibat) masih menjadi salah satu topik utama dalam kajian psikologi, terutama dalam metode eksperimen meskipun sejumlah orang bisa saja keliru terkait pada suatu temuan, karena kebenaran bersifat relatif dan mengalami dinamika terus menerus mengikuti perkembangan pemikiran dalam suatu masa.

Deskripsi kausal dan penjelasan kausal ini membedakan antara deskripsi kausal (causal description) dengan penjelasan kausal (causal explanation). Deskripsi kausal merupakan penggambaran akibat yang ditimbulkan oleh kesengajaan membuat variasi sebuah perlakuan. Metode eksperimen memiliki kekuatan pada deskripsi kausal. Penjelasan kausal adalah penjelasan tentang jalur mekanisme yang mana dan dalam kondisi apa hubungan kausal tersebut berlaku. Misalnya, Pada umumnya anak dengan mudah memahami hubungan kausal deskriptif antara perilaku menekan ceklikan tombol listrik dengan didapatkannya pencahayaan di sebuah ruangan. Namun, hanya sedikit anak dan bahkan orang dewasa mampu secara gamblang menjelaskan mengapa lampu menjadi bercahaya sesudah ceklikan tombol listrik ditekan. Penjelasan tersebut 
diuraikan dengan memecah perlakuan (perilaku menekan ceklikan tombol listrik) kedalam fitur yang efektif, (misalnya menutup sirkuit terisolasi) dan fitur yang tidak penting, misalnya, apakah tombol listrik itu ditekan oleh tangan atau oleh mesin (Haeruddin, 2003).

Eksperimen kuasi mempunyai tujuan yang sama dengan eksperimen acak, yakni menguji hipotesis kausal deskriptif mengenai sebab yang dimanipulasi. Eksperimen kuasi memiliki struktur serupa dengan eksperimen acak, misalnya mungkin ada pretes, postes atau kelompok kontrol untuk menegakkan inferensi kontrafaktual. Fitur pembeda yang menjadi ciri khas pada eksperimen kuasi adalah tidak adanya penempatan unit secara acak kedalam kelompok perlakuan dan pada kelompok kontrol. Penempatan objek pada kelompok dapat terjadi karena (a) seleksi-diri, yakni subjek atau individu memilih sendiri perlakuannya, (b) seleksi oleh administrator, yakni penempatan subjek atau individu ke kelompok perlakuan dilakukan oleh suatu profesi misalnya profesi guru, dokter, terapis, atasan atau pihak lain. Eksperimen kuasi melakukan manipulasi variabel sebab sebelum diamati pengaruhnya terhadap variabel lain, sehingga syarat sebab mendahului efek telah dipenuhi. Namun fitur penempatan non acak dari rancangan eksperimen kuasi kurang mendukung inferensi kausal (Maman, 2002).

Misalnya, kelompok kontrol bisa saja berbeda secara sistematis dengan kelompok perlakuan sehingga perbedaan dalam pengukuran dampak perlakuan bisa diterangkan oleh penjelasan alternatif. Konsekuensinya, peneliti perlu memikirkan dengan cermat bagaimana meniadakan (rules out) penjelasan alternatif untuk mendapatkan estimasi yang valid atas efek perlakuan. Situasi dapat berbeda seandainya peneliti menggunakan metode eksperimen acak, karena tidak terlalu perlu memikirkan penjelasan alternatif. Jika metode penempatan acak dilakukan dengan benar maka pada metode ini membuat penjelasan alternatif kecil kemungkinan sebagai penjelasan atas perbedaan dalam pengukuran dampak perlakuan (Masri et al., 1982).

Eksperimen natural adalah suatu model yang menggambarkan perbandingan kejadian alamiah antara sebuah perlakuan dengan kondisi pembanding. Seringkali kejadian tersebut tidak dapat dimanipulasi. Misalnya ketika peneliti secara retrospektif menguji apakah gempa bumi di Nepal (juga boleh terjadi gempa bumi di Yogya) menyebabkan menurunnya nilai properti. Inferensi kausal yang masuk akal mengenai efek gempa bumi tersebut dapat disusun dan dipertahankan. Gempa bumi terjadi sebelum peneliti mengukur nilai properti sehingga tidak sulit untuk menghubungkan gempa dengan nilai properti. 
Kontrafaktual terkait dengan proferti dan kejadian gempa bumi, maka peneliti tentunya mengukur nilai properti di tempat yang sama sebelum gempa terjadi atau di suatu tempat yang mirip namun tidak mengalami gempa bumi dalam saat yang sama. Jika nilai properti menurun sesaat sesudah gempa bumi di kondisi gempa bumi namun tidak menurun dikondisi pembanding, maka cukup sulit mencari penjelasan lain untuk menerangkan penurunan nilai properti tadi (Mehra, 1968).

Istilah rancangan korelasional, rancangan observasional pasif dan rancangan non eksperimental menggambarkan situasi dimana penyebab dan efeknya diidentikasi serta diukur namun fitur struktural lain dari eksperimen tidak ada. Misalnya, tidak ada penempatan secara acak maupun unsur rancangan seperti pretes dan kelompok kontrol yang berguna bagi peneliti untuk menyusun kontrafaktual inferensi kausal. Pada penelitian cross-sectional yang mengumpulkan seluruh data pada semua responden pada saat yang sama, peneliti biasanya kurang mampu menentukan bahwa sebab mendahului akibat. Fitur rancangan penelitian non eksperimental yang demikian membuat keraguan para pakar untuk menggunakan rancangan tersebut. Metode eksperimen dan generalisasi hubungan kausal mengisyaratkan bahwa kekuatan metode eksperimen terletak pada kemampuannya menjelaskan inferensi kausal, namun terdapat pada kelemahan eksperimen mengenai sejauh mana inferensi kausal tadi mampu digeneralisasikan (Moleong, 2002).

Keraguan terkait eksperimental muncul oleh karena pada umumnya eksperimen itu bersifat sangat lokal dan partikularistik. Eksperimen hampir selalu dilakukan dalam sebuah rekayasa tertentu yang terbatas, menggunakan satu metode perlakuan tertentu, bukan merupakan satu sampel hasil penga cakan dari populasi perlakuan. Biasanya sebuah eksperimen menggunakan pengukuran dampak perlakuan yang bukan hasil penyampelan secara acak dari populasi pengukuran dampak perlakuan yang ada. Setiap eksperimen hampir selalu menggunakan subjek penelitian yang berasal dari sampel convenient dan bukan sampel yang dipilih secara acak dari suatu populasi. Sebuah eksperimen seyogyanya dilakukan dalam periode waktu tertentu sehingga pada kurun waktu tertentu dengan cepat menjadi cacatan-catatan penting sebagai sebuah sejarah (Zen, 1984).

\subsection{Pandangan Filsafat terhadap Metode Kualitatif}


Pengertian metodologi penelitian dan metode penelitian berbeda. Secara metodologi penelitian biasanya masih bersifat konseptual atau teoritis, sehingga ketika kita belajar metodologi penelitian kita banyak berbicara tentang teoriteori dan konsep-konsep yang berkaitan dengan metode penelitian. Artinya kita masih banyak mengutip pendapat pakar dari berbagai literatur yang ada. Sementara yang dikehendaki dari bagian metode penelitian dalam proposal penelitian atau laporan penelitian adalah uraian tentang cara-cara yang dilakukan peneliti dalam menjawab pertanyaan yang dirumuskan biasanya dalam rumusan masalah penelitian.

Metode penelitian harus diuraikan sesuai dengan cara-cara yang dilakukan peneliti untuk menjawab rumusan masalah secara operasional, namun tetap melibatkan teori-teori yang diperoleh dari pelitian sebelumnya. Artinya metode atau langkah-langkah yang ditempuh harus sesuai dengan rumusan yang sudah ditetapkan oleh pakar. Beberapa contoh dalam memaparkan bagian metode penelitian sebelumnya perlu diketahui bahwa sub-bab yang ada pada bagian metode penelitian, memiliki urutan yang mungkin berbeda antara perguruan tinggi/instansi/lembaga yang satu dengan yang lain. Berdasarkan hal ini, maka topik yang harus dikemukakan dalam subbab pada kerangka penelitian kuantitatif tentu berbeda dengan kerangka penelitian kualitatif. Uraian ini menuntut peneliti untuk mampu memilah dan memilihnya sendiri model dan metode yang dapat digunakan (Muhadjir, 2000).

Secara umum bagian metode penelitian kualitatif berisi subbab: (1) pendekatan dan jenis penelitian, (2) kehadiran peneliti, (3) lokasi penelitian, (4) sumber data, (5) teknik pengumpulan data, (6) analisis data, dan (7) pengecekan keabsahan temuan penelitian, sedangkan penelitian kuantitatif berisi subbab: (1) pendekatan dan jenis penelitian, (2) populasi dan sampel, (3) instrumen penelitian, (4) teknik pengumpulan data, dan (5) analisis data. Sebelum memulai menulis bagian ini, hal penting yang harus diketahui adalah bagaimana bentuk pertanyaan yang dirumuskan dalam bagian rumusan masalah penelitian? Kadang-kadang juga ada rumusan masalah dinyatakan dalam kalimat pernyataan. Pertanyaan-pertanyaan ini dapat diketahui apakah pendekatan penelitian yang digunakan adalah pendekatan penelitian kuantitatif atau pendekatan penelitian kualitatif. Metode penelitian kuantitatif dengan teknik statistiknya diakui mendominasi analisis penelitian sejak abad ke-18 sampai kini di abad 21 (Mundiri, 2006).

Semakin canggihnya teknologi komputer, berkembang teknik-teknik analisis statistik yang mendukung pengembangan penelitian kuantitatif diprediksi 
semakin kuat dan banyak dilakukan para pakar dan saintis. Metode penelitian kuantitatif statistik menjadi lebih bergengsi daripada metode penelitian kualitatif. Hal ini disebabkan karena dalam penelitian kuantitatif kita menggunakan berbagai teknik-teknik analisis statistik. Menurut KBBI, metode diartikan sebagai "cara teratur yang digunakan untuk melaksanakan suatu pekerjaan agar tercapai sesuai dengan yang dikehendaki, cara kerja yang bersistem untuk memudahkan pelaksanaan suatu kegiatan penelitian guna mencapai tujuan yang ditentukan".

Menyusun metode penelitian, kita sebagai seorang peneliti sudah harus menggambarkan tentang cara-cara yang akan ditempuh atau digunakan untuk melaksanakan suatu kegiatan penelitian dalam menjawab pertanyaanpertanyaan yang dirumuskan dalam rumusan masalah. Artinya dengan membaca proposal penelitian kita, pembaca mengetahui cara-cara terperinci yang direncanakan oleh untuk dijalankan sebagai peneliti untuk menjawab rumusan penelitian, untuk itu calon peneliti harus dapat membedakan. Pernyataan ini menunjukkan bahwa metode itu suatu aktivitas yang sudah operasional, artinya metode sudah dapat dijadikan pedoman untuk melakukan kegiatan tertentu. Penelitian dapat diartikan bukan hanya sebagai seperangkat keterampilan yang dilakukan oleh berbagai profesi, melainkan cara berpikir, memeriksa secara kritis berbagai aspek pekerjaan, merumuskan prinsip, panduan yang mengatur prosedur tertentu, mengembangkan dan menguji sesuatu yang baru (Musianto, 2005).

\subsection{Pandangan Filsafat terhadap Metode Kuanlitatif}

Metode kuantitatif adalah suatu model sistematis yang dilaksanakan menurut pola tertentu dari yang paling sederhana sampai dengan yang kompleks, sehingga tercapai tujuan secara efektif dan efisien. Metode kuantitatif. Dilaksanakan dengan perencanaan, dan dilaksanakan dengan adanya unsur kesengajaan sebelum dilakukan penelitian. Artinya bahwa penelitian sudah dipikirkan langkah-langkah pelaksanaanya. Metode kuantitatif mengikuti prosedur penulisan ilmiah, mulai dari awal sampai dengan akhir kegiatan, penelitian dilakukan dengan mengikuti cara-cara atau langkah-langkah yang sudah ditentukan, yaitu prinsip yang digunakan untuk memperoleh ilmu 
pengetahuan, yang secara umum bertujuan untuk mencari kebenaran dalam pendekatan ilmiah maupun pendekatan non ilmiah (Muthahari, 2002).

\subsubsection{Karakteristik Penelitian Kuantitatif}

Pendekatan kuantitatif berdasarkan atas paradigma positivisme yang berpandangan bahwa peneliti dapat dengan sengaja mengadakan perubahan terhadap dunia. Karakteristik atas pendekatan kuantitatif yang dilandasi oleh paradigma positivisme adalah berisikan: (1) Logika eksperimen dengan memanipulasi variabel yang dapat diukur secara kuantitatif agar dapat dicari hubungan antara berbagai variabel; (2) Mencari hukum universal yang dapat meliputi semua kasus, meskipun dengan pengolahan statistik dicapai tingkat probabilitas dengan mementingkan sampel untuk mencari generalisasi; (3) Netralitas pengamatan dengan hanya meneliti gejala-gejala yang dapat diamati langsung dengan mengabaikan apa yang tidak dapat diamati dan diukur dengan instrumen yang valid dan reliabel, karena dengan netralitas memungkinkan penelitian dapatdireplikasi; (4) Bersifat atomistik, yaitu memecah kenyataan dalam bagian-bagian dan mencari hubungannya; (5). Bersifat deterministik, tertuju pada kepastian dengan mengadakan pengujian terhadap hipotesis dan (6) Memiliki tujuan pokok untuk mencapai generalisasi yang dapat digunakan untuk meramalkan atau memprediksi (Peursen, 1993).

\subsubsection{Sistematika Penulisan Dalam Penelitian Kuantitatif}

Langkah-langkah penelitian kuantitatif dapat diuraikan sebagai berikut:

1. Memilih judul penelitian kuantitatif

2. Melakukan studi pendahuluan

3. Merumuskan masalah

4. Merumuskan hipotesis Rancangan

5. Mengidentifikasi variabel

6. Menyusun definisi operasional

7. Membuat desain penelitian kuantitatif

8. Skala Pengukuran (mengumpulkan sumber data dan Pelaksanaan menganalisis) 


\section{Kerangka konseptual}

10. Menyusun Instrumen penellitian kuantitatif

11. Menarik Kesimpulan Laporan

12. Menulis Laporan

Langkah-langkah penelitian kuantitatif tersebut secara sederhana dapat diuraikan sebagai berikut:

1. Memilih judul penelitian kuantitatif merupakan tampilan utama penelitian yang dapat memberikan sugesti terhadap pembaca. Melihat judul diharapkan pembaca sudah dapat membayangkan keseluruhan isi dari penelitian yang hendak kita lakukan. Halaman judul hendaknya dibuat dengan sebaikbaiknya agar pembaca dapat membayangkan isi penelitian tersebut. Judul disusun sebaiknya mengukuti dan berisikan ciri-ciri penelitian kuantitatif, sehingga lebih memudahkan untuk merumuskan judul dalam penelitian kuantitatif, misalnya: (1) Judul dibuat singkat jangan terlalu panjang; (2) Judul harus konsisten dengan rumusan masalah; (3) Disusun dengan jumlah kata cukup; (4) Menghindari makna ganda dan makna bias; (5) Hindari akronim yang tidak lazim; (6) Sedikit bombastis; (7) Menyiratkan adanya harapan keberhasilan; (8) Harapan kemaslahanatan terhadap masyarakat dan (9) Memiliki masa depan dan keberhasilan untuk diterapkan, serta (10) ada inovasi (Poespowardojo, 1991).

2. Studi pendahuluan penelitian kuantitatif dimaksudkan untuk mengetahui informasi tentang kemungkinan peluang atau tidaknya kegiatan penelitian diteruskan di lapangan. Selain itu juga dimaksudkan untuk mencari informasi yang diperlukan oleh peneliti agar masalah dari judul yang telah ditetapkannya menjadi lebih jelas kedudukannya. Manfaat dari studi pendahuluan antara lain terkait dengan informasi yang didapat oleh peneliti mengenai: (1) Topik yang rencana diteliti; (2) Dimana dan kepada siapa informasi dapat diperole; (3) Bagaimana model memperoleh data atau informasi; (4) Teknik dan metode apa yang akan dugunakan untuk menganalisis data.

3. Membuat latar belakang masalah berisi tentang kesenjangan antara harapan (keadaan yang ideal atau yang semestinya) dan kenyataan yang terjadi di lapangan pada saat penelitian tersebut dapat dilakukan. Pada bagian ini, dijelaskan mengenai sesuatu yang mendorong peneliti untuk melakukan penelitian kuantitatif. Masalah yang baik memiliki ciri-ciri sebagai berikut: 
(1) Masalah mempunyai nilai penelitian yakni apabila mempunyai sifat keaslian, menyatakan suatu hubungan, merupakan hal yang penting, dapat diuji dan dinyatakan di dalam bentuk pertanyaan; (2) Mempunyai fisibilitas yang dapat dilaksanakan, yakni persyaratan ini akan terpenuhi apabila data serta metode untuk memecahkan masalah tersedia, cukup waktu, tenaga dan biaya untuk memecahkan masalah tersebut, ada dukungan dari pihak-pihak terkait, masalah tidak bertentangan dengan hukum, moral dan etika dan sesuai dengan kualifikasi si peneliti; (3) Hasil penelitian bermanfaat. Ciri ini sekaligus merupakan syarat terpenting bagi suatu kegiatan penelitian karena penelitian yang baik pada dasarnya dilakukan dalam rangka untuk menyumbangkan hasil penelitian tersebut demi kemajuan ilmu pengetahuan, meningkatkan efektifitas kerja, atau mengembangkan sesuatu yang sudah ada (Ravertz, 2004).

4. Sumber-sumber masalah penelitian dapat diperoleh dari (1) Pengalaman pribadi peneliti di dalam kehidupan sehari-hari; (2) Pengamatan pribadi terhadap lingkungan sekitar; (3) Bacaan-bacaan, baik yang ilmiah maupun yang non ilmiah. Penjelasan di atas, kita dapat menarik kesimpulan bahwasanya latar belakang masalah berisi tentang faktaatau kenyataan yang dapat dibuktikan melalui secara reliabel dan tentang peristiwa-peristiwa yang sedang terjadi di lapangan dan adanya penyimpangan-penyimpangan dari standard baik yang sudah ditetapkan dalam aturan keilmuan, sehingga latar belakang ini, peneliti harus mampu menunjukkan adanya suatu penyimpangan yang ditunjukkan dengan data dan menuliskan mengapa hal ini perlu diteliti.

5. Merumuskan masalah penelitian agar dapat dilakukan dengan sebaikbaiknya. Merumuskan masalah yang menjadi inti dan batasan penelitian, sehingga menjadi jelas dari mana harus memulai, ke mana harus diarahkan dan dengan apa bisa dijalankan. Umumnya masalah penelitian dirumuskan dengan memperhatikan ketentuan-ketentuan berikut: (1) Dirumuskan dalam bentuk pertanyaan; (2) Rumusan jelas dan padat; (3) Mencerminkan ciri penelitian yang dilakukan. Selain ketentuan di atas, masih terdapat beberapa ketentuan dapat diperhatikan, diantaranya: (1) Rumusan masalah harus merupakan dasar bagi perumusan judul; (2) Perumusan tujuan, dan (3) pembuatan hipotesis (Rowston, 1988)

6. Merumuskan hipotesis dapat dilakukan setelah peneliti telah mendalami permasalahan penelitian yang direncanakan dengan seksama serta menetapkan anggapan atau asumsi dasar, lalu membuat suatu teori 
sementara, yang kebenarannya masih perlu di uji kebenarannya. Hipotesis merupakan jawaban awal atau dugaan sementara terhadap permasalahan untuk dibuktikan atau diuji melalui penelitian yang sebenarnya yang dibuktikan secara empirik melalui data-data peneliltian. Selanjutnya peneliti bekerja berdasarkan hipotesis. Peneliti mengumpulkan data-data yang paling berguna untuk membuktikan hipotesis. Sesuai data yang terkumpul, peneliti kembali menguji apakah hipotesis yang dirumuskan dapat teruji kebenarannya atau sebaliknya. Terhadap hipotesis yang sudah dirumuskan, peneliti dapat bersikap dua hal yaitu: (1) Menerima keputusan seperti apa adanya seandainya hipotesisnya tidak terbukti (pada akhir penelitian) dan (2) Mengganti hipotesis seandainya melihat tanda-tanda bahwa data yang terkumpul tidak mendukung terbuktinya hipotesis (pada saat penelitian).

7. Uji validitas hipotesis bertujuan untuk mengetahui kedudukan hipotesis antara lain: (1) Perlu diuji apakah ada data yang menunjuk hubungan antara variabel penyebab dan variabel akibat; (2) Adakah data yang menunjukkan bahwa akibat yang ada, benar diakibatkan oleh penyebab tersebut; (3) Adanya data yang menunjukkan bahwa tidak ada penyebab lain yang bisa menimbulkan akibat tersebut. Apabila ketiga hal tersebut dapat dibuktikan, maka hipotesis yang dirumuskan harus mempunyai kedudukan yang kuat dalam penelitian kuantitatif (Ginting, 2008)

8. Menyusun definisi operasional, agar setiap variabel memiliki batas-batas yang jelas dan mudah untuk diukur, maka perlu dijabarkan arti dari setiap variabel tersebut dalam definisi operasional. Definisi operasional adalah suatu definisi mengenai variabel yang dirumuskan bedasarkan karakteristikkarakteristik variabel yang diamati yang memungkinkan peneliti untuk melakukan observasi atau pengukuran secara cermat terhadap suatu objek atau fenomena. Definisi operasional ditentukan berdasarkan parameter yang dijadikan ukuran dalam penelitian. Sedangkan cara pengukuran adalah model yang digunakan dimana variabel dapat diukur dan ditentukan karakteristiknya. Definisi operasional mencakup penjelasan tentang nama variabel, definisi variabel berdasarkan konsep/maksud penelitian, hasil ukur/kategori, dan skala pengukuran. Penyusunan definisi operasional variabel yang berdasarkan pada sifat dan indikator ini dapat disusun dengan logika berpikir kritis, pengetahuan ilmiah dan pengalaman empiris. Definisi operasional variabel berfungsi untuk mempertajam pemahaman konsep dan ruang lingkup variabelvariabel yang diambil peneliti sendiri, agar menjadi pedoman operasional bagi peneliti pada saat melaksanakan penelitian. Contoh definisi operasional dari dari variabel penelitian berdasarkan judul 
penelitian kuantitatif di atas adalah: (1) Variabel X1 = Motivasi prestasi. (2) Variabel X2 = adopsi inovasi pembelajaran Adopsi Inovasi Pembelajaran adalah suatu proses dimana inovasi dikomunikasikan melalui penemuan barudalam kegiatan belajar mengajar selama jangka waktu tertentu dan (3) Variabel $\mathrm{Y}=$ Kompetensi Mengajar Guru. Kompetensi mengajar guru adalah kemampuan, kecakapan dan keterampilan yang dimiliki oleh seorang guru dalam mengelola pembelajaran agar terciptanya pembelajaran yang mengacu pada pengaktifan kreatifitas siswa dalam kegiatan belajar menagajar (learning centered).

9. Membuat desain penelitian kuantitatif. Desain penelitian sangat penting dalam membuat penelitian. Desain penelitian merupakan rencana untuk memilih sumber-sumber dan jenis informasi yang dipakai untuk menjawab pertanyaan penelitian, kerangka kerja untuk merinci hubungan-hubungan antara variabel dalam penelitian, termasuk cetap biru atau patron yang memberi garis besar dari setiap prosedur penelitian mulai dari masalah/pertanyaan penelitian sampai dengan analisis data. Desain penelitian meliputi tujuan penelitian, tipe hubungan antar variabel, lingkungan penelitian dan pengendalian terhadap variabel, unit analisis, dimensi waktu, pengukuran konstruk, desain sampel, dan metode pengumpulan data. Tanpa desain yang benar seorang peneliti tidak dapat melakukan penelitian dengan baik karena tidak memiliki pedoman penelitian yang jelas. Banyak metode yang dapat digunakan untuk penelitian, antara lain: (1) Metode survey adalah metode untuk memperoleh fakta dari gejala yang ada dan mencari keterangan secara faktual baik tentang institusi sosial, ekonomi, politik, dan sebagainya; (2) Metode komparasional adalah metode penelitian deskriptif yang ingin mencari jawaban secara mendasar tentang sebab-akibat dengan menganalisis faktor-faktor penyebab terjadinya ataupun munculnya suatu fenomena tertentu; (3) Metode eksperimen adalah metode observasi di bawah kondisi buatan (artificial condition) di mana kondisi tersebut dibuat dan diatur oleh si peneliti (Gunawan, 2012)

\subsection{Aspek Idealisme, Realisme dan Holisme Pendidikan Filsafat}


Idealisme adalah salah satu aliran filsafat pendidikan yang berpaham bahwa pengetahuan dan kebenaran tertinggi adalah ide. Semua bentuk realita adalah manifestasi dalam ide. Pandangannya yang idealis itulah idealisme sering disebut sebagai lawan dari aliran realisme. Tetapi, aliran ini justru muncul sebagai umpan balik realisme yang menganggap realitas sebagai kebenaran tertinggi.

Secara logika, antara idealisme dan realisme tidak bisa dipertentangkan. Sebab, pencetus idealisme (Plato) adalah murid dari pencetus realisme (Socrates). Jika demikian, apakah mungkin Plato seorang idealis yang juga realis? atau pertanyaan lain, apakah Socrates yang realis juga seorang idealis? Apa sesungguhnya hakikat ide dan riil atau materi itu?

Idealisme menganggap, bahwa yang konkret hanyalah bayang-bayang, yang terdapat dalam akal pikiran manusia. Kaum idealisme sering menyebutnya dengan ide atau gagasan. Seorang realisme tidak menyetujui pandangan tersebut. Kaum realisme berpendapat bahwa yang ada itu adalah yang nyata, riil, empiris, bisa dipegang, bisa diamati dan lain-lain. Dengan kata lain sesuatu yang nyata adalah sesuatu yang bisa diindrakan (bisa diterima oleh panca indera) (Suprawati, 2009).

Pandangan konteks pendidikan, paham ini mencita-citakan pemikiran atau ide tertinggi. Secara kelembagaan institusional, maka pendidikan akan didominasi oleh fakultas atau jurusan filsafat dan pemikiran pendidikan, sedangkan pada di ranah dan level pendidikan dasar, akan didominasi oleh konsep-konsep dan pengertian-pengertian secara devinitif tentang segala sesuatu. Metode yang digunakan oleh aliran idealisme adalah metode dialektik, syarat dengan pemikiran, perenungan, dialog, dan lain-lain. Patron atau kurikulum yang digunakan dalam aliran idealisme adalah pengembangan kemampuan berpikir, dan penyiapan keterampilan bekerja melalui pendidikan praktis. Evaluasi yang digunakan dalam aliran idealisme adalah dengan evaluasi esay. Dimana evaluasi esay ini sangat efektif dalam proses belajar mengajar dan dalam meningkatkan keterampilan peserta didik dalam mengerjakan soal (Rahardjo, 2010).

Idealisme merupakan suatu aliran yang mengedepankan akal pikiran manusia. Sehingga sesuatu itu bisa terwujud atas dasar pemikiran manusia. Aspek pendidikan, idealisme dimaknai dengan suatu aliran yang berkontribusi besar demi kemajuan pendidikan. Hal tersebut bisa dilihat pada metode dan kurikulum yang digunakan. Idealisme mengembangkan pemikiran peserta didik sehingga menjadikan peserta didik mampu menggunakan akal pikiran atau 
idenya dengan baik dalam mengembangkan ilmu pengetahuan (Hastjarjo, 2010).

Holisme adalah suatu pemikiran yang menyatakan bahwa sistem alam semesta, baik yang bersifat fisik, kimiawi, hayati, sosial, ekonomi, mental-psikis, dan kebahasaan, serta segala kelengkapannya harus dipandang sebagai sesuatu yang utuh dan bukan merupakan kesatuan dari bagian-bagian yang terpisah. Sistem alam tidak dapat dipahami apabila kita mempelajarinya dengan cara memisahkan bagian-bagiannya: sistem harus dipelajari secara utuh sebagai suatu kesatuan. Kata 'holisme' pertama kali diperkenalkan pada tahun 1926 oleh Jan Smuts, seorang negarawan dari Afrika Selatan, dalam bukunya yang berjudul Holism and Evolution. Asal kata 'holisme' diambil dari bahasa Yunani, holos, yang berarti semua atau keseluruhan. Smuts mendefinisikan holisme sebagai sebuah kecenderungan alam untuk membentuk sesuatu yang utuh sehingga sesuatu tersebut lebih besar daripada sekadar gabungan-gabungan bagian hasil evolusi.

Contoh holisme dapat ditemukan di sepanjang sejarah manusia dan dalam konteks sosial budaya yang paling beragam ditegaskan melalui banyak studi etnologi. Seorang misionaris dari Prancis, Maurice Leenhardt, mencetuskan istilah cosmomorfisme untuk mengindikasikan adanya hubungan timbal-balik yang sempurna antara seseorang dengan lingkungannya. Hal tersebut ditemukan pada masyarakat Melanesia di Kaledonia Baru. Masyarakat di daerah tersebut, seorang individu yang terisolasi tidak memiliki status yang jelas sampai dia menemukan posisinya di lingkungan tersebut dengan mengenal seorang individu, tidak dapat dijadikan patokan bahwa kita telah mengenal sebuah komunitas (Harahap, 2011).

Lawan dari holisme adalah reduksionisme, yaitu suatu paham yang menyatakan bahwa suatu sistem yang kompleks dapat dijelaskan dengan cara mempelajari hal-hal yang menjadi dasar sistem tersebut (reduction). Misalnya, suatu proses biologis dapat dijelaskan melalui proses kimiawi. Lalu proses kimiawi tersebut dapat diterangkan melalui proses fisika. Akibatnya, proses fisika dapat menjelaskan proses kimiawi yang menjadi dasar terjadinya proses biologis. Holisme telah digunakan sebagai suatu slogan. Hal ini berkontribusi terhadap hambatan yang ditemui oleh interpretasi ilmiah terhadap holisme yang meyakini bahwa ada alasan ontologis yang mencegah model reduktif pada prinsipnya untuk menyediakan algoritme yang efisien dalam prediksi perilaku sistem dalam kelas-kelas tertentu. 
Holisme secara ilmiah percaya bahwa perilaku sistem tidak dapat diprediksi secara sempurna, tidak peduli berapa banyak data yang tersedia. Sistem alami dapat menghasilkan perilaku yang tidak terduga, dan diperkirakan bahwa perilaku sistem tersebut tidak dapat direduksi secara komputatif, sehingga tidak dapat memperkirakan keadaan sistem tersebut tanpa simulasi penuh semua kejadian yang terjadi dalam sistem. Karakteristik kunci dari perilaku tingkat tinggi pada kelas sistem tertentu dapat dimediasi oleh 'kejutan' yang langka pada perilaku unsur-unsurnya karena prinsip interkonektivitas, sehingga tidak dapat diprediksi kecuali dengan metode brute-force. Stephen Wolfram memberikan contoh perilaku automata seluler, yang pada umumnya sangat simpel namun kadang sangat sulit diprediksi (Raco, 2010)

Teori kompleksitas (science of complexity), merupakan turunan dari pemikiran sistem. Ilmu ini mencakup pendekatan komputasional dan holistik terhadap pemahaman sistem kompleks yang adaptif dan merupakan metode yang berlawanan dengan metode reduktif. Teori umum tentang kompleksitas telah diusulkan oleh beberapa lembaga dan departemen yang berfokus pada teori kompleksitas telah bermunculan di seluruh dunia. 


\section{Bab VIII}

\section{Irisan Filsafat terhadap Logika dan Silogisme}

\subsection{Filsafat dan Logika}

Kata philos memiliki arti kekasih atau sahabat, sedangkan kata sophia memiliki makna kebijaksanaan atau pengetahuan. Jadi, secara harfiah philosophia dapat diartikan sebagai yang mencintai kebijaksanaan atau sahabat pengetahuan. Para filsuf pra-Socrates menyebutkan bahwa filsafat adalah ilmu yang berupaya untuk memahami hakikat alam dan realitas ada dengan mengandalkan akal budi. Plato, mengatakan filsafat sebagai ilmu pengetahuan yang berusaha meraih kebenaran yang asli dan murni. Selain itu, Plato juga menyebutkan bahwa filsafat adalah penyelidikan tentang sebab-sebab dan asas-asas yang paling akhir dari segala sesuatu yang ada (Khaidir, 1990).

Aristoteles adalah murid Plato, mengatakan bahwa filsafat adalah ilmu pengetahuan yang senantiasa berupaya mencari prinsip-prinsip dan penyebabpenyebab dari realitas ada. Aristoteles juga menyebutkan bahwa filsafat adalah ilmu pengetahuan yang berupaya mempelajari being as being atau being as such. Sementara itu Rene Descartes mengatakan bahwa filsafat adalah himpunan dari 
segala pengetahuan yang pangkal penyelidikannya adalah mengenai Tuhan, alam, dan manusia (Basiq, 2010).

William James, filsuf dari Amerika mengatakan bahwa filsafat adalah suatu upaya yang luar biasa hebat untuk berpikir yang jelas dan terang. R.F. Beerling, guru besar filsafat Universitas Indonesia, mengatakan bahwa filsafat berupaya memajukan pertanyaan tentang kenyataan seluruhnya atau tentang hakikat, asas, dan prinsip dari kenyataan.

Konsep atau gagasan tentang definisi filsafat yang beragam tidak harus menjadikan kita bingung, akan tetapi justru memperlihatkan kepada kita bahwa betapa luasnya ruang lingkup filsafat sehingga tidak dibatasi oleh batasanbatasan yang mempersempit ruang gerak filsafat itu sendiri. Perbedaan perspektif dalam filsafat justru memperkaya wacana filsafat, sedangkan kesamaan dan kesatuan pikiran atau perspektif dalam filsafat justru akan mematikan dan mempersempit filsafat dengan sendirinya. Selanjutnya muncul pertanyaan, bagaimanakah filsafat itu tercipta? Hal apa yang menyebabkan manusia berfilsafat? Pada dasarnya ada empat hal yang merangsang manusia untuk berfilsafat, yaitu ketakjuban, ketidakpuasan, hasrat bertanya, dan keraguan (Hasyimsyah, 2001).

Menurut Aristoteles ketakjuban dianggap sebagai salah satu asal muasal filsafat. Pada awalnya manusia merasa takjub terhadap hal-hal yang ada disekitarnya, lama-kelamaan ketakjubannya semakin terarah kepada hal-hal yang lebih luas dan besar, seperti perubahan dan peredaran bulan, matahari, bintang-bintang, asal mula alam semesta, dan seterusnya. Ketakjuban macam ini hakikatnya hanya mungkin dirasakan dan dimiliki oleh mahluk yang selain memiliki perasaan juga mempunyai akal budi (rasio) (Noor, 1996).

Sebelum lahirnya filsafat, kehidupan manusia dikuasai dan diatur oleh berbagai macam mitos dan mistis. Berbagai macam mitos dan mistis tersebut berupaya menjelaskan tentang asal mula dan peristiwa-peristiwa yang terjadi dalam alam semesta, yang terjadi dalam kehidupan manusia sehari-hari. Sayangnya, ternyata penjelasan-penjelasan yang berasal dari mitos dan mistis tersebut makin lama makin tidak memuaskan manusia. Ketidakpuasan itu pada nantinya mendorong manusia untuk terus menerus mencari penjelasan dan keterangan yang lebih meyakinkan bagi dirinya, dan yang lebih akurat (Uhar, 2004).

Dilandasi oleh perasaan ketidakpuasan tadi dan upaya mencari penjelasan dan keterangan yang lebih pasti cepat atau lambat akan mengantarkan manusia tersebut kepada pemikiran yang rasional. Konsekuensinya adalah akal budi akan 
semakin berperan, dan justru semakin menggeser peran mitos dan mistis dalam kehidupan manusia. Pada saat rasio telah menghapus peran mitos dan mistis tadi, maka manusia telah mencapai level berfilsafat (Noam, 2000).

Ketakjuban manusia telah melahirkan pertanyaan-pertanyaan, dan ketidakpuasan manusia membuat pertanyaan-pertanyaan itu tidak kunjung habisnya. Dengan bekal hasrat bertanya maka kehidupan manusia serta pengetahuan semakin berkembang dan maju. Hasrat bertanyalah yang mendorong manusia untuk melakukan pengamatan, penelitian, serta penyelidikan. Ketiga hal tersebut yang menghasilkan pelbagai penemuan baru yang semakin memperkaya manusia dengan pengetahuan baru yang terus bertambah (Khaidir, 1990).

Manusia sendiri ketika mempertanyakan segala sesuatu dengan maksud untuk memperoleh kejelasan dan keterangan mengenai hal yang dipertanyakan tersebut, itu berarti dia sedang mengalami keraguan. Keraguan ini dilandasi bahwa sesuatu yang dipertanyakan tersebut belum terang dan belum jelas. Karena itu manusia perlu dan harus bertanya. Manusia bertanya karena masih meragukan kejelasan dan kebenaran dari apa yang telah diketahuinya. Jadi, dapat kita lihat bahwa keraguanlah yang ikut serta mendorong manusia untuk bertanya dan terus bertanya, yang kemudian menggiring manusia untuk berfilsafat, sehingga terus menerus memiliki hasrat bertanya maka filsafat akan tetap ada, dan akan terus ada. Filsafat dapat berhenti pada saat manusia telah berhenti mempertanyakan segala sesuatu (Mukhtar, 2014).

\subsubsection{Proses Kelahiran Filsafat}

Filsafat, sebagai bagian dari kebudayaan manusia yang amat menakjubkan, banyak dipahami lahir di Yunani dan dikembangkan sejak awal abad ke-6 SM. Para orang-orang Yunani ketika itu diyakini telah berhasil mengolah berbagai ilmu pengetahuan menjadi benar-benar rasional dan berkembang pesat. Pemikiran rasional-ilmiah itulah yang melahirkan filsafat. Para filsuf Yunani pertama, sebenarnya adalah para ahli matematika, astronomi, ilmu bumi, dan berbagai ilmu pengetahuan lainnya. Karena itu, pada tahap awal, filsafat mencakup seluruh ilmu pengetahuan.

Para filsuf Yunani pertama tersebut dikenal sebagai filsuf-filsuf alam. Mereka berpikir tentang alam: apakah inti dari alam, bagaimana menerangkan tentang bagaimana alam itu bisa ada, dan seterusnya. Dengan demikian, filsafat yang pertama lahir adalah filsafat alam (Afid, 2014). Perlu dicatat dari lahirnya filsafat 
adalah bahwa filsafat telah berani mengajak manusia untuk meninggalkan cara berpikir yang irasional dan tidak logis. Manusia kemudian beralih kepada jalan pemikiran yang rasional-ilmiah yang semakin lama semakin sistematis. Cara berpikir yang rasional-ilmiah itu pula yang menghasilkan gagasan dan pemikiran yang terbuka untuk diteliti oleh akal budi. Lebih dari itu, kebenarannya dapat didiskusikan lebih lanjut guna meraih konsep-konsep baru dan kebenaran-kebenaran baru yang diharapkan lebih sesuai dengan realitas sesungguhnya (Mundiri, 2002).

\subsubsection{Sifat Dasar Filsafat}

Berfilsafat artinya berpikir secara radikal. Filsuf adalah pemikir yang radikal, karena dengan berpikir radikal kita tidak pernah terpaku hanya kepada satu fenomena tertentu. Berpikir radikal tidak akan berhenti pada satu jawaban tertentu. Dengan berpikir radikal, filsafat berupaya untuk menemukan jawaban dari akar permasalahan yang ada. Filsafat berupaya mencari hakikat yang sesungguhnya dari segala sesuatu. Berpikir radikal bukan berarti hendak mengubah, membuang, atau menjungkirbalikkan segala sesuatu, melainkan dalam arti berupaya berpikir secara mendalam, untuk mencari akar persoalan yang dipermasalahkan. Berpikir radikal justru berupaya memperjelas realitas, melalui penemuan serta pemahaman akar realitas itu sendiri (Mundiri, 2008).

Filsafat bukan hanya mengacu kepada bagian tertentu dari realitas, akan tetapi berupaya mencari keseluruhan. Dalam memandang keseluruhan realitas, filsafat senantiasa berusaha mencari asas yang paling hakiki dari keseluruhan realitas. Mencari asas berarti berupaya menemukan sesuatu yang menjadi esensi realitas. Dengan menemukan esensi suatu realitas, realitas tersebut dapat diketahui dengan pasti dan menjadi jelas. Mencari asas adalah salah satu sifat dasar filsafat (Poespoprodjo, 1987).

Filsuf pada dasarnya adalah seorang pemburu kebenaran. Kebenaran yang diburunya merupakan kebenaran hakiki tentang seluruh realitas dan setiap hal yang dapat dipersoalkan. Maka dapat dikatakan bahwa berfilsafat artinya memburu kebenaran tentang segala sesuatu. Kebenaran itu sendiri harus bisa dipertanggungjawabkan. Artinya, kebenaran harus selalu terbuka untuk dipersoalkan kembali dan diuji demi meraih kebenaran yang lebih pasti. Dan begitu untuk seterusnya. Oleh karenanya dapat dikatakan bahwa kebenaran dalam artian filsafat tidak pernah bersifat mutlak dan final, akan tetapi selalu 
bergerak dari satu kebenaran menuju kebenaran baru yang lebih pasti (Surajiyo, 2013).

Filsafat muncul salah satunya disebabkan adanya keraguan. Untuk mengatasi keraguan tersebut maka dibutuhkan yang namanya kejelasan. Ada filsuf yang mengatakan bahwa berfilsafat artinya berupaya mendapatkan kejelasan dan penjelasan mengenai seluruh realitas. Geisler dan Feinberg (1981: 18-19) mengatakan bahwa ciri khas penelitian filsafati adalah adanya usaha keras demi mencapai kejelasan intelektual (intellectual clarity) (Soekardijo, 2001).

Berpikir secara radikal, mencari asas, memburu kebenaran, dan mencari kejelasan tidak mungkin dapat berhasil dengan baik tanpa berpikir secara rasional. Berpikir secara rasional artinya berpikir secara logis, sistematis, dan kritis. Berpikir logis adalah bukan sekedar menggapai pengertian-pengertian yang dapat diterima oleh akal sehat, tetapi juga agar sanggup menarik kesimpulan dan mengambil keputusan yang tepat dan benar dari premis-premis yang digunakan (Susanto, 2013

Berpikir logis juga menuntut pemikiran yang sistematis. Pemikiran yang sistematis adalah rangkaian pemikiran yang berhubungan satu sama lain atau saling berkaitan secara logis. Tanpa disertai pemikiran yang logis-sistematis dan koheren, tidak mungkin dicapai kebenaran yang bisa dipertanggungjawabkan. Berpikir kritis artinya menjaga kemauan untuk terus-menerus mengevaluasi argumentasi yang mengklaim dirinya adalah benar. Seseorang yang berpikiran kritis tidak mudah meyakini suatu kebenaran begitu saja tanpa benar-benar menguji keabsahan kebenaran tersebut (Sou'yb, 2001).

\subsubsection{Cabang-Cabang Filsafat}

Menurut Achmadi (1000: 13-16) dalam studi filsafat untuk memahaminya secara baik paling tidak kita harus mempelajari 5 (lima) bidang pokok, yaitu: Metafisika, Epistemologi, Logika, Etika, dan Sejarah Filsafat.

Metafisika merupakan cabang filsafat yang memuat suatu bagian dari persoalan filsafat yang: membicarakan tentang prinsip-prinsip yang paling universal; membicarakan sesuatu yang bersifat keluarbiasaan (beyond nature), membicarakan karakteristik hal-hal yang sangat mendasar, yang berada di luar pengalaman manusia (immediate experience); berupaya menyajikan suatu pandangan yang komprehensif tentang segala sesuatu; membicarakan 
persoalan-persoalan seperti: hubungan akal dengan benda, hakikat perubahan, wujud tuhan, kehidupan setelah kematian, dan seterusnya (Uhar, 2004).

Epistemologi lazimnya disebut sebagai teori pengetahuan yang secara umum membicarakan mengenai sumber-sumber, karakteristik, dan kebenaran pengetahuan. Persoalan epistemologi (teori pengetahuan) berkaitan erat dengan persoalan metafisika. Bedanya, persoalan epistemologi berpusat pada apakah yang ada? Memuat tentang: Problem asal pengetahuan (origin), apakah sumbersumber pengetahuan? Dari mana pengetahuan yang benar dan bagaimana kita dapat mengetahuinya? Seterusnya, problem pengetahuan (appearance), yang menjadi karakteristik pengetahuan? Apakah dunia riil di luar akal, apakah ada dapat diketahui? Problem mencoba kebenaran (verification), apakah pengetahuan kita itu benar? Bagaimanakah membedakan antara kebenaran dengan kekeliruan? Dan seterusnya (Suparlan, 2005).

Logika adalah bidang pengetahuan yang mempelajari segenap asas, aturan, dan tata cara penalaran yang betul (correct reasoning). Pada mulanya logika sebagai pengetahuan rasional. Oleh Aristoteles logika disebutnya sebagai analitika, yang kemudian dikembangkan oleh para ahli Abad Tengah yang disebut logika tradisional. Mulai akhir abad ke-19 oleh George Boole logika tradisional dikembangkan menjadi logika modern, sehingga dewasa ini logika telah menjadi bidang pengetahuan yang amat luas yang tidak lagi semata-mata bersifat filsafati, tetapi bercorak teknis dan ilmiah.

Etika atau filsafat perilaku sebagai cabang filsafat yang membicarakan "tindakan" manusia, dengan penekanan yang baik dan yang buruk. Terdapat dua hal permasalahan, yaitu menyangkut "tindakan" dan "baik-buruk". Apabila permasalahan jatuh pada "tindakan" maka etika disebut sebagai filsafat praktis; sedangkan jika jatuh pada "baik-buruk" maka etika disebut sebagai"filsafat normatif" (Sirajuddin, 2004).

Pemahaman tentang"etika" sebagai pengetahuan mengenai norma-norma baikburuk dalam tindakan mempunyai persoalan yang luas. Etika yang demikian ini mempersoalkan tindakan manusia yang dianggap baik yang harus dijalankan, dibedakan dengan tindakan buruk/jahat yang dianggap tidak manusiawi. Sejalan dengan ini, etika berbeda dengan "agama" yang di dalamnya juga memuat dan memberikan penilaian baik-buruk dalam tindakan manusia. Karena etika mengandalkan pada rasio yang lepas dari sumber wahyu agama yang dijadikan norma dalam agama, dan etika lebih cenderung bersifat analitis daripada praktis. Sehingga etika adalah ilmu yang bekerja secara rasional. Sementara dari kalangan non-filsafat, etika sering digunakan sebagai pola bertindak praktis 
(etika profesi), misalnya bagaimana menjalankan bisnis yang bermoral (dalam etika berbisnis) (Alex, 1983).

Sejarah filsafat adalah laporan suatu peristiwa yang berkaitan dengan pemikiran filsafat. Biasanya sejarah filsafat ini memuat berbagai pemikiran kefilsafatan yang beraneka ragam mulai dari zaman pra-Yunani hingga zaman modern. Juga, dengan mengetahui pemikiran filsafat para ahli pikir (filsuf) diperoleh dari berbagai aneka ragam pemikiran dari dahulu hingga sekarang. Sejarah filsafat dapat diketahui pemikiran-pemikiran yang jenius hingga pemikir tersebut dapat mengubah dunia, yaitu dengan ide-ide atau gagasan-gagasannya yang cemerlang (Poespoprodjo, 2006).

\subsubsection{Kegunaan Filsafat}

Ketika filsafat baru lahir, ilmu pengetahuan masih merupakan bagian yang tak terpisahkan dari filsafat itu sendiri. Ketika itu para pemikir yang terkenal sebagai filsuf adalah juga ilmuwan. Para filsuf zaman itu juga merupakan ahli-ahli astronomi, ilmu bumi, matematika, dan sebagainya. Bagi mereka, ilmu pengetahuan adalah filsafat dan filsafat adalah ilmu pengetahuan itu sendiri. Filsafat telah membantu manusia membebaskan diri dari metode berpikir yang dikuasai oleh mitos dan mistis bahkan beralih kepada model berpikir yang rasional, luas dan mendalam, jelas dan sistematis, logis, kritis, dan analitis. Karena itu, ilmu pengetahuan pun semakin tumbuh dan terus berkembang, dan menjadi dewasa. Kemudian, berbagai ilmu pengetahuan yang telah mencapai tingkat kedewasaan penuh satu demi satu mulai mandiri dan meninggalkan filsafat yang selama ini telah mendewasakan mereka. Itulah sebabnya filsafat disebut sebagai mater scientiarum atau induk segala ilmu pengetahuan. Filsafat telah berperan dalam melahirkan, merawat, dan mendewasakan berbagai ilmu pengatahuan yang begitu berjasa bagi kehidupan manusia (Jujun, 1984).

Filsafat memang abstrak, namun tidak berarti bahwa filsafat sama-sekali tidak ada hubunganya dengan kehidupan sehari-hari yang konkret. Filsafat pada hakikatnya membantu manusia dalam memahami dan menjalankan kehidupan mereka sehari-hari dengan menggunakan cara berpikir yang lebih rasional dan tidak hanya mengandalkan mitos, mistis atau sekedar intuisi dan perasaan. Dengan belajar filsafat diharapkan dapat menambah ilmu pengetahuan, karena dengan bertambahnya ilmu pengetahuan akan bertambah pula cakrawala pemikiran, cakrawala pandangan yang semakin luas. Sehingga akan dapat 
membantu penyelesaian masalah yang selalu kita hadapi dengan cara yang lebih bijaksana (Zainun, 2006).

Dasar semua tindakan adalah ide. Sesungguhnya filsafat di dalamnya memuat ide-ide yang fundamental. Ide-ide itulah yang akan membawa manusia ke arah suatu kemampuan untuk merentang kesadarannya dalam segala tindakannya, sehingga manusia akan dapat lebih hidup, lebih tanggap (peka) terhadap diri dan lingkungannya, lebih sadar terhadap hak dan kewajibannya.Dengan adanya perkembangan ilmu pengetahuan dan teknologi kita semakin ditantang dengan memberikan alternatifnya. Di satu sisi kita dihadapkan dengan kemajuan teknologi beserta dampak negatifnya, perubahan sedemikian cepatnya, pergeseran nilai-nilai, dan pada nantinya manusia semakin jauh dari tata nilai dan moralitas (Sumaryono, 1999).

Di sisi lainnya, apabila kita tidak berani menghadapi kemajuan ilmu pengetahuan dan teknologi konsekuensinya kita akan menjadi manusia yang terbelakang. Untuk itu kita berusaha mengejar kemajuan dengan segala upaya. Semakin jauhnya kita dari tata nilai dan moralitas, akibatnya banyak ilmuwan kehilangan bobot kebijaksanaannya. Sehingga apa yang dihasilkan ilmu pengetahuan dan teknologi bersamaan dengan itu pula manusia kehilangan pendirian dan dihantui kebingungan dan keraguan (skeptis). Ilmu pengetahuan yang bersandingan dengan filsafat akan menghasilkan ilmu yang disertai dengan kebijaksanaan dalam penerapannya dalam kehidupan manusia (Surajiyo dkk., 2006).

\subsection{Silogisme dan Fissafat}

Menurut Bahasa Sebuah silogisme (bahasa Yunani: syllogismos atau kesimpulan atau bisa juga dimaknai sebagai inferensi) atau banding logis adalah jenis argumen logis di mana satu proposisi (kesimpulan) yang disimpulkan dari dua orang lain (tempat) dari suatu bentuk tertentu, yaitu kategori proposisi. Menurut Istilah, Bahasan Mantiq Silogisme atau Qiyas diartikan sebagai kumpulan dari beberapa qadhiyyah yang berkaitan yang jika benar, maka dengan sendirinya (li dzatihi) akan menghasilkan qadhiyyah yang lain (baru) (Sirajuddin, 2004). 
Beberapa macam hujjah (argumentasi). Manusia disaat ingin mengetahui halhal yang majhul, maka terdapat tiga cara untuk mengetahuinya (Poespoprodjo, 2006):

1. Pengetahuan dari juz'i ke juz'i yang lain. Argumentasi ini sifatnya horizontal, dari sebuah titik yang parsial ke titik parsial lainnya. Argumentasi ini disebut tamtsil (analogi).

2. Pengetahuan dari juz'i ke kulli. Atau dengan kata lain, dari khusus ke umum (menggeneralisasi yang parsial) Argumentasi ini bersifat vertikal, dan disebut istiqra' (induksi).

3. Pengetahuan dari kulli ke juz'i. Atau dengan kata lain, dari umum ke khusus. Argumentasi ini disebut qiyas (silogisme).

Silogisme/Qiyas dibagi menjadi dua; (1) Iqtirani (silogisme kategoris) dan (2) istitsna'i (silogisme hipotesis). Sesuai dengan definisi qiyas di atas, satu qadhiyyah atau beberapa qadhiyyah yang tidak dikaitkan antara satu dengan yang lain tidak akan menghasilkan qadhiyyah baru. Jadi untuk memberikan hasil (konklusi) diperlukan beberapa qadhiyyah yang saling berkaitan. Dan itulah yang namanya qiyas. (Partap, 2002).

Pengertian Silogisme dalam buku "Sebelum Analytics", Aristoteles mendefinisikan silogisme sebagai "sebuah wacana di mana, hal-hal tertentu yang telah seharusnya, sesuatu yang berbeda dari hal-hal seharusnya hasil dari kebutuhan karena hal-hal ini begitu."

Silogisme adalah suatu pengambilan kesimpulan, dari dua macam keputusan (yang mengandung unsur yang sesuai dan salah satunya harus universal) suatu keputusan yang ketiga, yang kebenarannya sama dengan dua keputusan yang mendahuluinya. Maka bisa disimpulkan, bahwa silogisme adalah suatu proses penarikan kesimpulan secara deduktif, yang disusun dari pernyataan dan konklusi (kesimpulan).Penalarannya bertolak dari pernyataan bersifat umum menuju pada pernyataan/simpulan khusus.

Membicarakan silogisme mengenal dua istilah yaitu absah dan benar. Absah (valid) berkaitan dengan prosedur apakah pengambilan konklusi sesuai dengan patokan atau tidak. Dikatakan valid apabila sesuai dengan patokan dan tidak valid bila sebaliknya. Benar berkaitan dengan: Proposisi dalam silogisme itu dan didukung atau sesuai dengan fakta atau tidak (Mchra, 1996). Hanya konklusi dari premis yang benar prosedur yang sah konklusi itu dapat diakui. Mengapa demikian? Karena bisa terjadi: 
Premis salah dan prosedur valid menghasilkan konklusi yang benar. Demikian juga dari premis salah dan prosedur invalid dihasilkan konklusi benar.

1. Variasi-Variasi (Nasution Hakim, Andi. 1005: 78-81)

Prosedur valid, premis salah dan konklusi benar.

Semua manusia itu penjahat.

(salah)

Semua penjahat itu sholeh.

Jadi: Semua penjahat itu manusia.

(benar)

2. Prosedur invalid (tak sah), premis benar dan konklusi salah.

Drs. Roshicin adalah dosen UNISMA.

(benar)

Prof. Musthofa bukan Drs Rishicin.

(benar)

Jadi: Prof. Mustofa bukan dosen UNISMA.

3. Prosedur invalid, premis salah dan konklusi benar.

Sebagian mahasiswa adalah batu.

Sebagian manusia adalah batu.

Jadi: Sebagian manusia adalah mahasiswa.

4. Prosedur valid,premis salah dan konklusi salah.

Semua perempuan tidak shalat.

Semua mahasiswa adalah perempuan.

(salah)

Jadi: Semua mahasiswa tidak shalat.

(salah)

\subsection{Konsep Silogisme}

\subsubsection{Silogisme Kategorik}

Silogisme Kategorik adalah silogisme yang semua proposisinya merupakan kategorik. Proposisi yang mendukung silogisme disebut dengan premis yang kemudian dapat dibedakan dengan premis mayor (premis yang termnya menjadi predikat), dan premis minor (premis yang termnya menjadi subjek). Yang 
menghubungkan antara kedua premis tersebut adalah term penengah (middle term). (Mundiri. 2002: 44)

Contoh:

Semua Tanaman Membutuhkan air

(premis mayor) .M........................

Akasia adalah Tanaman

(premis minor) S................

Akasia Membutuhkan air (konklusi)

...........................

( $\mathrm{S}=$ Subjek, $\mathrm{P}=$ Predikat, dan $\mathrm{M}=$ Middle term)

Hukum-Hukum Silogisme Kategorik (Mundiri. 2008: 45-53).

Dari dua premis yang sama-sama negatif, tidak menjadi kesimpulan apa pun, karena tidak ada mata rantai yang menghubungkan kedua proposisi premisnya. Kesimpulan diambil bila sedikitnya salah satu premis positif. Kesimpulan yang ditarik dari dua premis negatif adalah tidak sah.

Contoh (1):

Kerbau bukan bunga mawar.

Kucing bukan bunga Mawar ...... (Tidak ada kesimpulan)

Contoh (2):

Tidak satu pun drama yang baik mudah dipertunjukkan.

Tidak satu pun drama Shakespeare mudah dipertunjukkan.

Jadi: Semua drama Shakespeare adalah baik. (Kesimpulan tidak sah)

Paling tidak salah satu dari term penengah harus mencakup. Dari dua premis yang term penengahnya tidak tentu menghasilkan kesimpulan yang salah.

Contoh:

Semua ikan berdarah dingin.

Binatang ini berdarah dingin

Jadi: Binatang ini adalah ikan.(Padahal bisa juga binatang melata) 
Term-predikat dalam kesimpulan harus konsisten dengan term predikat yang ada pada premisnya. Bila tidak, kesimpulan menjadi salah.

Contoh:

Kerbau adalah binatang.

Kambing bukan kerbau.

Jadi: Kambing bukan binatang.('Binatang' pada konklusi merupakan term negatif sedangkan pada premis adalah positif)

Term penengah harus bermakna sama, baik dalam premis mayor maupun premis minor. Bila term penengah bermakna beda kesimpulan menjadi lain.

Contoh:

Bulan itu bersinar di langit.

Januari adalah bulan.

Jadi: Januari bersinar di langit.(Bulan pada premis minor adalah nama dari ukuran waktu yang panjangnya 31 hari, sedangkan pada premis mayor berarti planet yang mengelilingi bumi) (Hidayat, 2018).

Dari dua premis yang sama-sama partikular tidak sah diambil kesimpulan.

Contoh:

Beberapa politikus tidak jujur.

Banyak cendekiawan adalah politikus.

Jadi : Banyak cendekiawan tidak jujur.

Jadi : Beberapa pedagang adalah kikir.

\subsubsection{Silogisme Hipotesis}

Silogisme hipotesisi adalah argumen yang premis mayornya berupa proposisi hipotetik, sedangkan premis minornya adalah proposisi kategorik. (Arikunto, Suharsimi. 2006: 91)

Hukum-Hukum Silogisme Hipotesis

Mengambil konklusi dari silogisme hipotetik jauh lebih mudah dibanding dengan silogisme kategorik. Tetapi yang penting di sini dalah menentukan 
kebenaran konklusinya bila premis-premisnya merupakan pernyataan yang benar. (Arikunto, Suharsimi. 006: 91)

Contoh:

Bila antecedent kita lambangkan dengan A dan konsekuen dengan B, jadwal hukum silogisme hipotetik adalah:

1) Bila A terlaksana maka B juga terlaksana.

1) Bila A tidak terlaksana maka $B$ tidak terlaksana. (tidak sah $=$ salah)

3) Bila B terlaksana, maka A terlaksana. (tidak sah = salah)

4) Bila B tidak terlaksana maka A tidak terlaksana.

Kebenaran hukum di atas menjadi jelas dengan penyelidikan berikut:

Bila terjadi peperangan harga bahan makanan melambung tinggi. Nah, peperangan terjadi.Jadi harga bahan makanan melambung tinggi.( benar = terlaksana). Benar karena mempunyai hubungan yang diakui kebenarannya, Bila terjadi peperangan harga bahan makanan melambung tinggi. Nah, peperangan terjadi. Jadi harga bahan makanan tidak membumbung tinggi (tidak $\mathrm{sah}=\mathrm{salah})$

Tidak sah karena kenaikan harga bahan makanan bisa disebabkan oleh sebab atau faktor lain.

\subsubsection{Silogisme Disjungtif}

Silogisme Disjungtif adalah silogisme yang premis mayornya keputusan disjungtif sedangkan premis minornya kategorik yang mengakui atau mengingkari salah satu alternatif yang disebut oleh premis mayor.Seperti pada silogisme hipotetik istilah premis mayor dan premis minor adalah secara analog bukan yang semestinya. (Arikunto, Suharsimi. 1006: 97)

Maka silogisme Janis ini terdiri atas premis mayor berupa proposisi alternatif. Proposisi alternatif yaitu bila premis minornya membenarkan salah satu alternatifnya. Kesimpulannya menolak alternatif yang lain. (Arikunto, Suharsimi. 1006:99)

Contoh:

My : : Kucing berada di dalam rumah atau di luar rumah 
Mn : Kucing berada di luar rumah

$\mathrm{K} \quad$ : Jadi, kucing tidak berada di dalam rumah

Macam-Macam Silogisme Disjungtif dan Hukum-Hukumnya. Silogisme disjungtif dalam arti sempit dan silogisme disjungtif dalam arti sempit mayornya mempunyai alternatif kontradiktif.

Contoh:

Saya lulus atau tidak lulus.

Ternyata Saya lulus

Jadi Saya bukan tidak lulus.

Hukum Silogisme dalam arti sempit

Premis minornya mengingkari salah satu alternatif, konklusi-nya adalah mengakui alternatif yang lain.

Contoh:

Ardi berada di luar atau di dalam.

Ternyata tidak berada di luar.

Jadi Ardi berada di dalam.

Premis minor mengakui salah satu alternatif, kesimpulannya adalah mengingkari alternatif yang lain.

Contoh:

Budi di masjid atau di sekolah.

Budi berada di masjid.

Jadi Budi tidak berada di sekolah.

Budi di masjid atau di sekolah.

Budi berada di sekolah.

\subsubsection{Silogisme disjungtif dalam arti luas.}

Silogisme disjungtif dalam arti luas premis mayornya mempunyai alternatif bukan kontradiktif. 
Contoh:

Hasan di rumah atau di pasar.

Ternyata tidak di rumah.

Jadi di pasar.

Hukum Silogisme dalam arti luas

Bila premis minor mengakui salah satu alterna konklusinya sah (benar).

Contoh:

Budi menjadi guru atau pelaut.

Ia adalah guru.

Jadi bukan pelaut.

Bila premis minor mengingkari salah satu konklusinya tidak sah (salah)

Contoh (1):

Penjahat itu lari ke Solo atau ke Yogya.

Ternyata tidak lari ke Yogya.

Jadi Ia lari ke Solo. (Bisa jadi Ia lari ke kota lain).

Supaya silogisme dapat merupakan jalan pikiran yang baik ada beberapa hukum dalam silogisme. Hukum tersebut bukanlah buatan para ahli-pikir, tapi hanya dirumuskan oleh para ahli itu. Di bawah ini hukum-hukum yang menyangkut term-term antara lain:

Hukum pertama. Silogisme tidak boleh lebih atau kurang dari tiga term. Kurang dari tiga term berarti bukan silogisme. Jika sekiranya ada empat term, apakah yang akan menjadi pokok perbandingan, tidak mungkinlah orang membandingkan dua hal denga dua hal pula, dan lenyaplah dasar perbandingan (Burhanuddin, 1988).

Hukum kedua. Term antara atau tengah (medium) tidak boleh masuk (terdapat) dalam kesimpulan. Term medium hanya dimaksudkan untuk mengadakan perbandingan dengan term-term. Perbadingan ini terjadi dalam premis-premis. Karena itu term medium hanya berguna dalam premis-premis saja.

Hukum ketiga. Wilayah term dalam konklusi tidak boleh lebih luas dari wilayah term itu dalam premis. Hukum ini merupakan peringatan, supaya dalam 
konklusi orang tidak melebih-lebihkan wilayah yang telah diajukan dalam premis. Sering dalam praktek orang tahu juga, bahwa konklusi tidak benar, oleh karena tidak logis (tidak menurut aturan logika), tetapi tidak selalu mudah menunjuk, apa salahnya itu (Hidayat, 2018).

Term antara (medium) harus sekurang-kurangnya satu kali universal. Jika term antara particular, baik dalam premis mayor maupun dalam premis minor, mungkin saja term antara itu menunjukkan bagian-bagian yang berlainan dari seluruh luasnya. Kalau demikian term antara, tidak lagi berfungsi sebagai term antara, dan tidak lagi menghubungkan atau memisahkan subyek dengan predikat.

Contoh:

Beberapa politisi pembohong.

Usman adalah politikus.

Usman adalah pembohong.

Sedangkan hukum-hukum yang menyangkut premis-premis (keputusankeputusan) antara lain: (Mundiri. 2008: 30-48)

Jika kedua premis (mayor dan minor) positif, maka kesimpulannya harus positif juga.

Kedua premis tidak boleh negatif, sebab term antara (medium) tidak lagi berfungsi sebagai penghubung atau pemisah subjek dengan predikat. Dalam silogisme sekurang-kurangnya subjek atau predikat harus dipersamakan oleh term antara (medium)

Contoh:

Batu adalah bukan binatang

Anjing adalah bukan batu

Anjing adalah bukan binatang. 


\section{Filsafat di Era Generasi Milenial}

\subsection{Pentingkah Filsafat di Era Milenial}

Perkembangan teknologi yang cukup pesat di era milenial saat ini memaksa masyarakat terutama generasi muda bergerak cepat dan bergaya hidup serba instan. Generasi milenial saat ini (pada tahun 1017) adalah mereka yang berusia 17-36 tahun; mereka yang kini berperan sebagai mahasiswa, early jobber, dan orangtua muda. Milenial lahir antara tahun 1981-2000. (Suseno, 1999)

Bisa dirasakan bagaimana pengaruh Gadget yang didukung teknologi internet terhadap kehidupan manusia khususnya generasi milenial. Hampir seluruh aktivitas mereka tidak bisa lepas dari peran gadget ini, mulai dari gaya berpakaian hingga gaya hidup, serta mengkonsumsi makanan instan hingga menyerap berita secara instan tanpa nalar kritis yang tidak dibatasi oleh ruang dan waktu. Merebaknya informasi yang begitu cepat tentu memiliki dampak buruk terhadap tatanan kehidupan masyarakat. Banyaknya berita hoax (bohong) dan informasi menyesatkan yang langsung ditelan mentah-mentah tanpa adanya 
filter oleh generasi milenial merupakan ancaman yang harus diantisipasi. Saat ini sudah terlihat mulai tergerusnya nilai-nilai moral dan etika dalam berkomunikasi dan menyebarkan informasi di media sosial yang diatur dalam agama. Padahal dalam tatanan sosial kemasyarakatan, etika sangat diperlukan guna menghindari terjadinya pergesekan yang berujung kepada konflik (Nasution, 1999).

Untuk mengantisipasi hal tersebut, maka penting kiranya generasi milenial ini mempelajari Filsafat untuk menyeimbangkan arus teknologi informasi yang semakin pesat ini. Sebagai ilmu yang menempatkan akal sebagai raja pengetahuan, filsafat mengajak manusia kembali ke akal, mengembalikan dan meningkatkan daya kritis. Bisa saja realitas disaksikan dengan indra, tapi realitas mesti disimpulkan dengan akal. Di negara filosof, kebohongan tak akan diminati. Kebohongan diminati, sebab kebohongan ditampilkan seolah-olah sebagai kebenaran. Dengan akal, kebohongan akan terlihat sebagai kebohongan (Rasjidi \& Harifuddin, 1998).

\subsection{Relevansi Filsafat di Era Milenial}

Filsafat sering sekali dipandang sebagai pemikiran yang membingungkan bahkan menyesatkan umat manusia. Pandangan semacam ini tentunya sangat disayangkan, karena filsafat secara esensial justru sangat penting artinya bagi kehidupan manusia, khususnya dalam menyelesaikan berbagai persoalan kemanusiaan. Filsafat secara umum adalah berpikir secara menyeluruh, mendalam, radikal dan rasional, tentang sesuatu.

Menurut Syamsuddin Arif dan Dinar Dewi Kania dalam Adian Husaini, filsafat itu mencari kebenaran. Dengan bertanya secara terus menerus tentang segala hal, dari persoalan gajah sampai persoalan semut, dari soal hukum, dan politik hingga soal moral dan metafisika dan sebagainya. Rizal dan Misnal yang dikutip Himyari Yusuf juga mengemukakan bahwa filsafat merupakan sebuah disiplin ilmu yang terkait dengan perihal kebijaksanaan. Sedangkan kebijaksanaan merupakan titik ideal dalam kehidupan manusia, karena ia dapat menjadikan manusia untuk bersikap dan bertindak atas dasar pertimbangan kemanusiaan yang tinggi. Dengan demikian dapat dikatakan bahwa filsafat adalah berpikir secara menyeluruh, radikal dan rasional sebagai proses yang tanpa henti untuk 
mencari kebenaran secara terus menerus dan pada akhirnya dapat memahami makna segala sesuatu termasuk makna kehidupan manusia (Leahy, 2012).

Menurut Fazlur Rahman yang dikutip oleh Muhammad Muslih, bahwa filsafat itu sangat diperlukan untuk menerobos kemacetan dan jalan buntu yang dihadapi ilmu, baik keilmuan alam, sosial maupun humanisme, termasuk masalah-masalah keagamaan. Oleh karena itu Muhammad Muslih menekankan bahwa filsafat bagaimanapun adalah alat intelektual yang terus menerus diperlukan (filsafat sebagai pendekatan). Dikatakan demikian karena filsafat membiasakan akal pikiran untuk bersikap kritis-analitis dan mampu melahirkan ide-ide segar yang dibutuhkan dalam hidup manusia, maka filsafat menjadi alat yang sangat penting bagi intelektual dalam mengembangkan berbagai ilmu pengetahuan termasuk dalam agama dan teologi (Firdaus, 2012).

Relevan dengan penjelasan di atas Zubaidi Mastal mengemukakan, berbagai problematika yang muncul ke permukaan, apabila tidak dipolakan dan ditampilkan dari pengkajian secara menyeluruh dan mendasar (filsafat), maka tetap akan memberikan atau menimbulkan citraan yang negatif, baik terhadap nilai-nilai moral dan agama, maupun terhadap fungsi dan tujuannya. Demikian urgensinya filsafat menurut para pakar tersebut, yang sejatinya adalah untuk kepentingan kehidupan manusia, yaitu filsafat sebagai alat (pendekatan) dalam mengkaji dan menyelesaikan berbagai problem yang muncul dalam kehidupan manusia, khususnya bagi masyarakat kontemporer dewasa ini (Iffah, 2017)

Lebih rinci The Liang Gie mengemukakan bahwa berbagai konsepsi dan pengertian filsafat yang berlainan, sesungguhnya dapat diikhtisarkan pada beberapa konsepsi, yang di antaranya adalah filsafat sebagai ilmu, filsafat sebagai kritik pengetahuan(pendekatan), dan filsafat sebagai pandangan hidup. Wibisono yang dikutip oleh Muslih mengemukakan, untuk menghindari kesimpangsiuran dalam pemahaman apa itu filsafat, maka perlu dibedakan antara filsafat dengan ilmu filsafat. Pengertian filsafat yang digunakan seharihari cenderung merupakan asas atau pendirian yang kebenarannya telah diterima dan diyakini serta digunakan sebagai dasar dalam menjawab masalahmasalah fundamental yang dihadapi dalam kehidupan manusia dan filsafat yang ini diberi konotasi filsafat sebagai pandangan hidup (Hamyari, 2016).

Wibisono menambahkan bahwa filsafat sebagai ilmu tidak berbeda dengan cabang-cabang ilmu lainnya. Namun ilmu filsafat mempunyai perbedaan pada objek formalnya. Ilmu filsafat mempertanyakan hakikat (substansi) atau apanya objek sasaran yang diteliti dan objek itu dipahami dari keutuhan atau totalitasnya.10 Berdasarkan berbagai pandangan di atas, secara empirik 
menunjukkan bahwa filsafat sangat urgen bagi kehidupan manusia. Urgensi filsafat tidak hanya pada bidang ilmu pengetahuan, tetapi meliputi seluruh aspek kehidupan manusia, termasuk permasalahan moral dan agama. Terlebih bagi masyarakat kontemporer yang tengah menghadapi permasalahan sangat kompleks, atau hampir pada setiap aspek kehidupan menghadapi problem yang harus diselesaikan (Abdurrozzaq et al., 2020)

Secara faktual kehidupan masyarakat kontemporer sudah banyak mengalami berbagai kemajuan, dan kemajuan tersebut secara kausalitas seiring dengan perkembangan ilmu pengetahuan yang sangat pesat dan spektakuler. Fakta menunjukkan bahwa perkembangan ilmu pengetahuan telah melahirkan berbagai teknologi canggih, terutama teknologi dalam bidang komunikasi dan transformasi. Kedua bidang teknologi telah mampu mengubah peradaban manusia yang luar biasa. Dunia seakan tanpa batas, semua menjadi mengglobal dan terasa tanpa sekat atau demarkasi pembatas yang memisahkan negara yang satu dengan lainnya, komunitas yang satu dengan lainnya, bahkan antara individu dengan individu lainnya. Namun disisi lain kemajuan tersebut di atas juga harus diakui telah menimbulkan berbagai kegamangan sikap hidup dan kegersangan jiwa. Kegamangan sikap hidup dan kegersangan jiwa yang dialami masyarakat pada era belakangan dapat dikatakan sebagai akibat dari menipisnya nilai-nilai moral dan agama (Mahawati et al., 2021).

Moral dan agama cenderung ditempatkan pada lahan yang tidak bertuan, dalam arti seakan tidak ada manfaat dan tidak ada kaitannya dengan kehidupan praktis manusia. Fakta menunjukkan bahwa masyarakat kontemporer secara esensial telah ber-Tuhan kepada kebebasan (liberalisme), dan kebendaan yang sesuai dengan keinginan dan kepuasan nafsu keserakahan, sehingga kebenaran yang menjadi ukuran adalah yang sesuai benda dan dengan nafsu. Kehidupan masyarakat pada era kontemporer atau yang juga disebut postmodern dewasa ini, yang paling faktual adalah ditandai oleh mengglobalnya peradaban. Paradigma kehidupan semacam itu secara umum dipacu oleh berbagai kecanggihan berpikir dan pesatnya perkembangan ilmu pengetahuan yang disertai dengan berbagai teknologi yang spektakuler sebagaimana telah disinggung di atas. Penting untuk dipertegas kembali bahwa sebagai implikasi dari perkembangan ilmu pengetahuan dan teknologi telah berhasil mengantarkan kehidupan manusia sampai ketatanan yang sangat mengagumkan dan bahkan membahagiakan secara fisik (Marzuki, 2021).

Misalnya seseorang ingin berkomunikasi dengan orang lain yang berada ditempat yang jauh, baik itu untuk urusan bisnis, maupun urusan politik dan lain 
sebagainya, tidak perlu lagi bersusah payah, cukup dengan menggunakan teknologi komunikasi, dan dalam hitungan detik saja sudah bisa dilakukan dan diselesaikan. Selain itu masyarakat yang sebelumnya masih bersifat agraris telah berubah dan berkembang menjadi masyarakat industrialis. Fakta semacam ini dapat dilihat di daerah-daerah seluruh pelosok tanah air. Namun perlu dipertegas kembali bahwa pada sisi yang lain perubahan itu telah banyak pula menimbulkan krisis atau kemiskinan yang sangat mendasar. Misalnya telah terjadi kekeringan nilai-nilai moral dan spiritual (miskin spiritualitas), bahkan pada tatanan yang lebih esensial paradigma kehidupan global dan teknologi canggih dewasa ini telah melahirkan keterpurukan nilai-nilai kemanusiaan yang sudah sampai pada tingkat yang sangat memprihatinkan (Natasya et al., 2020).

Kehidupan masyarakat yang mengetepikan nilai-nilai moral dan agama, bahkan menganggapnya nilai-nilai tersebut sebagai realitas yang kosong tanpa makna, agama hanya dianggap sebagai persoalan pribadi dan masalah alam lain (akhirat), sehingga ranah nilai-nilai agama yang dilandasi oleh keyakinan kepada Tuhan sebagai simpul dari keimanan dianggap tidak lebih tinggi dari nilai-nilai kemewahan fisik material semata. Semua yang bersifat fisik-material merupakan tolok ukur segala sesuatu, yang pantang diragukan akan kebenarannya. Karakteristik kehidupan seperti itulah yang dikemukakan oleh Zubaidi Mastal, bahwa kehidupan manusia di era post modern sekarang ini diwarnai oleh sikap dan perilaku atau peradaban yang sekularistik. Paham sekularisme sangat mementingkan hidup kekinian dan menyeret manusia kepada sikap acuh tak acuh akan nilai-nilai moral dan agama serta mengikat diri dengan dunia yang semata-mata bersifat fisik bendawi (Purba et al., 2020).

Pandangan di atas secara kontemplatif menunjukkan bahwa kemajuan ilmu pengetahuan dan teknologi merupakan penjelmaan dari pengetahuan ilmiah yang diklaim bebas nilai, kemudian keterasingan perilaku manusia dari nilainilai moral dan agama adalah konsekuensi dari karakteristik pengetahuan ilmiah yang sekularistik, yang memisahkan urusan dunia dengan urusan moral dan agama (semua urusan duniawi dianggap tidak ada kaitannya dengan agama). Dalam tampilan realitas seperti itulah filsafat harus tampil (sebagai pendekatan) untuk mengkaji moral dan agama bagi kehidupan masyarakat kontemporer dewasa ini. Dengan perkataan lain urgensi filsafat terletak pada penyelesaian persoalan kemanusiaan yang dewasa ini semakin rumit dan kompleks, antara lain mengenai moral dan agama.

Dengan demikian dapat dipahami, bahwa urgensi filsafat adalah dalam rangka memformulasi dan mengaktualisasikan kembali nilai-nilai moral dan agama 
yang sudah terlalu lama berserakan dan ditinggalkan, sehingga dengan kajian filsafat diharapkan nilai-nilai tersebut dapat tumbuh subur dalam kehidupan praktis manusia, yang akhirnya kehidupan masyarakat kontemporer akan menjadi kuat dalam segala kreativitas dan aktivitas, karena selain berilmu pengetahuan yang luas, juga tidak terpisah atau tercerai dari moral dan agama. Oleh karena itu diharapkan dapat tampil para intelektual yang berkarakter kemanusiaan sejati dan tangguh dalam menghadapi berbagai tantangan yang terjadi dewasa ini, serta senantiasa mengutamakan ketinggian moralitas yang berdasarkan pada agama (Islam) secara komprehensif dan mendasar (Purba et al., 2020).

Pandangan tersebut di atas, diperkuat oleh Abuddin Nata dan Amin Abdullah yang mengemukakan sebagai upaya untuk mengembalikan pengetahuan ilmiah yang bebas nilai dan telah membuat keterasingan peradaban manusia dari nilainilai moral dan agama, hendaklah dikaji dengan pendekatan filosofis, sehingga apa yang menjadi hakikat, fungsi dan tujuan moral dan agama dapat dipahami dan diaktualisasikan. Dalam pada itu dapatlah dikatakan bahwa yang dapat memainkan peran secara optimal dalam pengkajian dan penggalian nilai-nilai hakiki moral dan agama adalah filsafat sebagai metode atau pendekatan.

\subsection{Filsafat Umum dalam Pemikiran Milenial}

Telah dijelaskan pengertian Filsafat secara umum adalah berpikir secara menyeluruh, mendalam, radikal dan rasional, tentang sesuatu. Melihat pengertian tersebut maka perlu dijabarkan ciri-ciri dari filsafat antara lain,

- Sistematis, unsur-unsur dalam pemikirannya saling berkaitan satu sama lain dengan teratur dalam suatu keseluruhan.

- Koheren, dalam berpikir unsur-unsur nya tidak boleh mengandung uraian yang bertentangan satu sama lain namun tetap memuat uraian yang jelas dan logis.

- Rasional, harus berdasar pada kaidah berfikir yang benar.

- Komprehensif, melihat objek tidak dari satu sudut pandang tertentu saja tapi menyeluruh.

- Radikal, berpikir secara mendalam sampai menyentuh akar persoalannya. 
- Universal, muatan kebenarannya sampai pada tingkat umum mengarah pada realita hidup secara keseluruhan.

Berdasarkan ulasan di atas bila dikaitkan dengan era milenial saat ini tentu sangat relevan untuk dipelajari. Sayangnya kaum muda dalam berfilsafat di era milenial ini, rupanya masih jauh panggang dari api. Labelisasi terhadap filsafat sebagai ilmu abstrak dengan tingkat kesulitan berpikir yang melelahkan acapkali membuat generasi milenial malas berfilsafat. Keengganan generasi milenial dalam berfilsafat dengan kekhasan metodologi berpikir keras, cermat dan tuntas, rupanya dilatari oleh masifnya mentalitas praktis sebagai implikasi langsung dari modernitas (Sudarmanto et al., 2020).

Membludaknya persebaran gawai, informasi dan komunikasi berbasis daring, dipandang sebagai solusi dalam mengatasi ragam persoalan. Pada aras inilah, daya imajinatif-konstruktif generasi milenial dilumpuhkan. Alhasil, bobot penalaran minimal kedalaman. Filsafat sebagai sistem ilmu berpikir kritis, sejatinya mesti dicintai oleh generasi era milenial ini. Dalam dinamika informasi yang seringkali menampilkan lapisan luaran, ambigu dan syarat rasionalitas, filsafat hadir untuk membuka cakrawala berpikir baru, analitis, logis, kritis, sistematis dan mendalam (Sudarmanto et al., 2020).

Berhadapan dengan membludaknya hoaks, cara berpikir filsafat membantu untuk membedah dan menentukan mana yang harus diterima dan mana yang harus dihindari. Dengan sistem berpikir filsafat, kaum milenial setidaknya dimampukan untuk mengamalkan suatu prinsip moral yang dikatakan oleh salah satu filsuf dan teolog zaman Skolastik Thomas Aquinas, "Bonum est prosequendum et malum vitandum" (Melakukan yang baik dan menghindari yang jahat).

Dewasa ini, ketika generasi milenial dituntut untuk kritis, inovatif, kreatif dan produktif dalam menghadapi percaturan global, filsafat hadir dan membuka jalan ke arah itu. Dengan berfilsafat generasi milenial dimampukan untuk melihat apa yang tidak dilihat oleh orang lain dan mendengar apa yang tidak didengar orang lain. Filsafat selalu menghadirkan suatu penglihatan yang melampaui. Berhadapan dengan era kekinian, ketika kebenaran dijadikan komoditas (Post-truth Era), filsafat membantu generasi milenial untuk membuat diskresi demi mencapai suatu kebenaran hakiki yang dapat dijadikan landasan hidup. Pada tataran ini, generasi milenial sebenarnya mengalami suatu kepenuhan eksistensial dari perspektif nurani juga ratio (Syafrizal et al., 2021). 
Di sisi lain, berhadapan dengan percaturan politik yang menuntut keterlibatan aktif-kontributif kaum muda, filsafat membantu generasi milenial untuk lebih jeli melihat substansi persoalan yang sedang digeluti. Ini menjadi kekhasan yang membedakan generasi milenial dengan elit-elit politik bangsa yang akhir-akhir ini cenderung bermain di ranah aksidental. Bukan tidak mungkin bahwa filsafat kemudian membuka peluang bagi generasi milenial untuk unjuk teladan berpolitik yang sehat, rasional dan fair bagi elit politik tua yang rentan menjadikan "tanah suci" politik sebatas langgam pertempuran irasionalitas yang memuakkan (Syafrizal et al., 2021).

Dari ulasan di atas maka generasi milenial harus mengoptimalkan arah pemikirannya sesuai filsuf-filsuf yang dulu akan tetapi juga harus memperbaharui pemikiran-pemikiran yang lebih modern tanpa membuang apa yang sudah diajarkan oleh para filsuf terdahulu karena filsafat itu tidak selalu mengacu pada hal-hal yang dulu akan tetapi acuannya adalah keadaan dan pemikiran pada masanya.

\subsection{Urgensi Filsafat dalam Era Globalisasi}

Filsafat diharapkan dapat berdiri di tengah-tengah ilmu-ilmu pengetahuan dan teknologi yang berkembang di era globalisasi saat ini. Filsafat ilmu (kritis) yang dimaksud disini adalah memiliki fungsi reflektif dan pragmatis, yaitu menempatkan klaim-klaim analitis ilmu-ilmu pengetahuan dalam rangka proses transformasi abadi masyarakat dan umat manusia. Dengan demikian filsafat ilmu memberikan teoritis-etis bagi ilmu-ilmu pengetahuan dan masyarakat.

Menurut Poespoprodjo, hakikat ilmu adalah persoalan fundamental dan kebenaran universal yang implisit melekat di dalam dirinya. Dengan memahami filsafat ilmu, berarti memahami seluk-beluk ilmu yang paling mendasar, sehingga dapat dipahami pula perspektif ilmu, pengembangannya, keterjalinan antar cabang ilmu yang satu dengan yang lain, serta simplifikasi dan artifisialitasnya. Itulah sebabnya aktualitas filsafat ilmu semakin terasa.

Dengan filsafat ilmu manusia akan semakin dapat memperluas cakrawala wawasan ilmiahnya. Ketajaman refleksi, kedalaman imajinasi, kepekaan intuisi manusia akan terpacu sedemikian rupa sehingga terhindar dari bahaya keracunan intelektual, simplisisme berpikir yang memuakkan, kehanyutan dalam arus konservatisme ilmu yang timbul karena ilmu dipandang sebagai kata 
benda (noun) atau barang jadi (take for granted) yang sudah selesai, mandek dan tertutup.

Dengan filsafat ilmu manusia juga akan mampu mensublimasikan disiplin ilmu yang menjadi tanggung jawabnya masing-masing, dan mengangkatnya ke dataran filsafati, sehingga manusia dapat memahami perspektif serta berbagai kemungkinan arah pengembangannya; supaya manusia bisa melakukan spekulasi-spekulasi yang mendalam guna menemukan teori-teori atau paradigma-paradigma baru yang tepat-guna bagi kepentingan umat manusia. Tanpa kesanggupan itu manusia akan hanya menjadi konsumen ilmu orang lain, membeo, menjadi 'his master's voice'-nya orang lain, itu pun masih dengan kemungkinan adanya distorsi ilmiah, karena lemahnya pemahaman atau penguasaan dalam bahasa asing (Sudarmanto, . et al. 2020).

Adalah tugas filsafat ilmu di tengah-tengah ilmu-ilmu untuk mengembalikan kecanggihan konseptual yang berlebihan pada pangkalnya yang sederhana namun fundamental, menyingkapkan kaitan klaim objektif dengan matra kekuasaan dan kepentingan, dan pada gilirannya membantu proses pemahaman dan peningkatan diri dan masyarakat. Dalam perkembangannya filsafat ilmu juga mengarahkan ilmuwan pada strategi pengembangan ilmu, yang menyangkut etik dan heuristik, bahkan sampai pada dimensi kebudayaan untuk menangkap -tidak saja kegunaan atau kemanfaatan ilmu -tetapi juga arti dan maknanya bagi kehidupan umat manusia. Dari situ dapat diketahui, betapa pentingnya kedudukan filsafat ilmu dalam perkembangan ilmu pengetahuan.

\subsection{Bagaimana Masa Depan Filsafat terhadap Generasi Milenial}

Mungkin pernah terlintas di benak kita untuk melihat kembali relevansi filsafat di era milenial yang ditandai dengan pesatnya perkembangan Ilmu Pengetahuan dan Teknologi, akankah kita kembali berhadapan dengan teori-teori usang filsafat yang bersifat 'abadi' karena seakan tak pernah selesai dibahas.

Dalam Esai Filsafat untuk Masa Kini dikatakan bahwa filsafat yang terefleksi dalam teori fisika atau pembentukan teori lainnya tidak pernah dapat tersingkirkan, bahkan pada Simposium Internasional di Ljubljana, Yugoslavia, pada 10-11 Mei 1984 dikatakan bahwa pada era sekarang terjadi refleksi yang 
kembali memunculkan masalah-masalah filsafat yang disangka telah tersingkirkan. Bila keterangan ini dikaitkan dengan hubungan yang terjadi antara kemajuan teknologi---termasuk dampak negatifnya---dengan filsafat, maka sebenarnya kita dapat mengkompromikan kedua unsur ini menjadi solusi, yaitu bagaimana memposisikan filsafat sebagai solusi alternatif (Syafrizal et al., 2021).

Secara istilah, ada beberapa pengertian dari para ahli pendidikan. Langeveld yang dikutip oleh Burhanuddin Salam berpendapat bahwa pendidikan adalah suatu bimbingan yang diberikan oleh orang dewasa kepada anak yang belum dewasa untuk mencapai tujuan, yaitu kedewasaan.3 Azyumardi Azra berpendapat bahwa pendidikan "merupakan suatu proses penyiapan generasi muda untuk menjalankan kehidupan dan memenuhi tujuan hidupnya secara lebih efektif dan efisien".4 Sedang dalam UU RI No. 20 Tahun 2003 disebutkan bahwa pendidikan adalah "usaha sadar dan terencana untuk mewujudkan suasana belajar dan proses pembelajaran agar peserta didik secara aktif mengembangkan potensi dirinya untuk memiliki kekuatan spiritual keagamaan, pengendalian diri, kepribadian, kecerdasan, akhlak mulia, serta keterampilan yang diperlukan dirinya, masyarakat, bangsa dan negara"(Barni, 2019).

Unsur-unsur pendidikan dalam definisi di atas terdiri dari usaha (kegiatan) yang bersifat bimbingan dan dilakukan secara sadar, pendidik (pembimbing), anak didik, dasar dan tujuan, dan alat-alat yang digunakan dalama usaha itu. Dengan istilah lain, sebagai suatu sistem pendidikan memiliki unsur pelaku (organik) dan bukan pelaku (anorganik). Unsur pelaku adalah pendidik, peserta didik, dan unsur bukan pelaku berupa piranti keras (hardware) dan piranti lunak (software), seperti tujuan, sarana, dan lingkungan (Barni, 2019). Dengan demikian dapatlah dikatakan bahwa pendidikan sebagai sebuah sistem terdiri dari tujuan, metode, materi (kurikulum), pendidik, anak didik, alat pendidikan, dan lingkungan. Semua unsur ini saling berkaitan satu sama lain. Pendidikan saat ini menghadapi berbagai tantangan, antar lain bisa dilihat dari karakter anak. Karakter anak zaman now semakin nyeleneh dan semaunya sendiri. Anak-anak cenderung egois, tidak suka bekerja sama. Hal ini disebabkan seringnya mereka lebih suka bermain game lewat ponsel android daripada permainan tradisional yang mengajarkan perilaku untuk bekerjasama. Fenomena ini tidak bisa dipungkiri, baik itu di kota maupun di pelosok desa sekalipun. Karakter anak pada sebagian generasi millenial memprihatinkan Natasya et al., 2020). Mereka kadang tidak menghargai orangtua maupun gurunya. Bahkan dari mereka juga terkadang terjebak pada dunia kriminal dan narkoba. Generasi millenial dalam minat belajar juga sebagian besar mengalami kemunduran.Di era millennial, 
kecenderungan dunia pendidikan antara lain: berkembangnya model belajar jarak jauh (Distance Learning), mudahnya menyelenggarakan pendidikan terbuka, sharing resource bersama antar lembaga pendidikan, perpustakaan dan instrument pendidikan lainnya (guru, dosen, laboratorium) berubah fungsi menjadi sumber informasi daripada sekedar rak buku. Lembaga pendidikan akan menghadapi sebuah perubahan yang signifikan akibat proses digital ini. Ini menjadi sebuah peluang dan cara untuk meningkatkan kualitas pendidikan sekaligus tantangan bagi dunia pendidikan di Indonesia (Soedarmanto et al, 2020).

Memformat gaya baru berfilsafat agar lebih 'membumi' di era teknologi ini. Filsafat harus diupayakan dapat bersifat praktis dan dapat menjadi salah satu elemen fungsi kontrol dalam mengkaji 'gerakan' manusia. Dengan memberi perhatian yang sepadan terhadap filsafat, dapat diupayakan terjadinya kebangkitan kembali suatu pemikiran falsafi dengan gaya yang baru, hal yang dibutuhkan untuk penyesuaian dengan kosmos yang selalu bergerak dinamis. Dan filsafat dapat menuntun manusia untuk setia pada kewajiban dan menjadi manusia yang berkarakter dan berintegritas tinggi yang dapat memahami kehidupan dengan lebih baik. Tentu saja filsafat dalam kesendiriannya---sebagai konsep tunggal---tidak cukup dan harus digandengan dengan konsep dari disiplin lain, agama dan ilmu pengetahuan misalnya.

Filsafat menggunakan metode analisa yang rasional mendalam dalam memandang suatu permasalahan, sehingga dengan sedikit 'penyesuaian' filsafat akan tetap layak bersanding di era teknologi. Berikut ini adalah beberapa upaya untuk lebih 'membumikan' filsafat di era teknologi. Mengupayakan rehumanisasi dan re-rasionalisasi dengan filsafat seperti yang dicanangkan oleh Jurgen Habermas . Untuk mengakomodir perkembangan zaman di era teknologi, filsafat dapat diposisikan sebagai salah satu acuan untuk melakukan re-humanisasi dan re-rasionalisasi, agar tercipta masyarakat yang lebih baik. Filsafat lebih difungsikan sebagai ilmu kritis yang tetap mampu membahas permasalahan manusia dengan mendalam, terbuka, mengutamakan kebenaran secara kontinu (Rasjidi, 1998).

Berfilsafat di era teknologi harus lebih digerakan pada kecenderungan pembahasaan keilmuan dan tidak 'melulu' dipenuhi pembahasan teologis. Seperti yang pernah terjadi di era al farabi dan Ibn Rusyd yang terbukti secara empiris dapat memicu berkembangnya tradisi analitik, yang kelak menumbuhkan tradisi berpikir saintis. Harus lebih diupayakan terjadinya gaya pemikiran filsafat baru yang memungkinkan terjadinya hubungan antara ilmu 
dan filsafat, dan ini menjanjikan masa depan baru dengan adanya refleksi atas filsafat.. 


\section{Daftar Pustaka}

Abdullah, Muhammad, and Muhammad Junaid Nadvi (2011) "Understanding the principles of Islamic world-view." The Dialogue 6(3): 268-289

Abdurrozzaq Hasibuan, B. P. et al. (2020) Teknik Keselamatan dan Kesehatan Kerja. Edited by J. Simarmata. Medan. Available at: https://kitamenulis.id/2020/11/16/teknik-keselamatan-dan-kesehatankerja/.

Abele, S., Stasser, G., dan Chartier, C (2010) Conflict and Coordination in the Provision of Public Goods: A Conceptual Analysis of Continuous and Step-Level Games. Personality and Social Psychology Review, vol. 14(4), pp.385 -401.

Abror, Turmudi (2013) "Pendidikan Demokratis Dan Partisipasi Publik."Jurnal Pemikiran Keislaman 18(2).

Adam, (2012) to Noah-The Numbers Game: Why the Genealogy Puzzles of Genesis 5", Leonard Timmons.

Adian, Donny Gahral (2003) Martin Heidegger. Jakarta: Teraju

Adib, Muhammad, (2010) Filsafat Ilmu Ontologi, Epistimologi, Dan Logika Ilmu Pengetahuan, (Yogyakarta: Pustaka Pelajar)

Afid Burhanuddin, (2014) Filsafat Ilmu: Sarana Berpikir Ilmiah. Paper: STKIP PGRI PacitanAmsal Bakhtiar, Filsafat Ilmu. Jakarta: Raja Grafindo Persada 
Agbor, E. (2008) Creativity and innovation: The leadership dynamics. Journal of strategic leadership, 1(1),

Albiruni (1950) Maker's of Pakistan and Modern Muslim India. Lahore: Kasmir Bazaar.

Alex Lanur OFM, (1983) Logika Selayang Pandang, Yogyakarta: Penerbit Kanisius

Ali, Mukti, (1975) Meningkatkan Penelitian Ilmu-Ilmu Agama, Yogyakarta: alJamiee ah IAIN Sunan Kalijogo

Alimatus Sa'diyah Alim (2020) 'Hakikat Manusia, Alam Semesta, dan Masyarakat dalam Konteks Pendidikan Islam', Jurnal Penelitian Keislaman, 15(2), pp. 144-160. doi: 10.20414/jpk.v15i2.1760.

Alo Liliweri (2005) Prasangka dan konflik (Cultural identity and multiculturalism related to ethnic and social conflict, analysis and resolution in Indonesia).PT LKiS Pelangi AksaRA.

Alrasyid, M. Harun (2012) Zaman Bergerak (Analisis Historis tentang Awal Perjuangan Politik Indonesia Masa Kolonialisme 1912-1926). Jurnal FISIP: MADANI, 3, 01.

Amalia, Euis, (2005) Sejarah Pemikiran Ekonomi Islam dari Masa Klasik Hingga Kontemporer, (Jakarta: Pustaka Asatruss), cet. 1, h. 4

Amelz, (1952) HOS Tjokroaminoto Hidup dan Perjuangannya Jilid I. Jakarta: Bulan bintang.

Amin, M. (2014) 'Holistic Leadership', Journal of Holistic Nursing, 32(4), pp. 248-249, doi: 10.1177/0898010114555702.

Amin, M. Masyhur (1980) Saham HOS Tjokroaminoto dalam kebangunan Islam dan nasionalisme di Indonesia. Nur Cahaya

Amsal Bakhtiar, (2004) Fisafat Ilmu, (Jakarta: Grafindo Persada, 2004), hal. 5

Amsal Bakhtiar, (2013) Filsafat Ilmu, (Jakarta: Raja Grafindo Persada, edisi revisi), hlm. 21-27

Angel, Richard B, I(1964), Reasoning and Logic, Century Crafts, New York,

Anonim, (1950) The Mystery of Being Volume I: Reflection and Mystery. London: The Harvill Press. 
Anonim, (1983) Departemen Pendidikan dan Kebudayaan. Materi Dasar Pendidikan Program Akta Mengajar V. Metodologi Penelitian.

Aune, Bruce (1998) Metaphysics the Elements. London: University of Minnesota Press

Bagir, Haidar, (2005), Buku Saku Filsafat Islam, Penerbit Arasy, PT Mizan Pustaka, Bandung.

Bahrani, Z. (1998), "Conjuring Mesopotamia: imaginative geography a world past", dalam Meskell, L., Archaeology under fire: Nationalism, politics and heritage in the Eastern Mediterranean and Middle East, London: Routledge, hlm. 159-174, ISBN 978-0-415-19655-0

Bahri, Media Zainul (2009) "Esoterisme dan Kesatuan Agama-Agama" dalam Jurnal Titik Temu, Volume 2, No. 1, hlm 117.

Barni, Mahyuddin, (2019) Tantangan Pendidik Di Era Millennial, J. Transformatif, Vol. 3(1): 100-116

Basiq Djalil, (2010) Logika (Ilmu Mantiq), Jakarta: Kencana Prenada Media

Beheshtifar, M., dan Kamani-Fard, F.-B. (2013) Organizational Creativity: A Substantial Factor to Growth. International Journal of Academic Research in Business and Social Sciences. Vol. 3(3), pp.1-7.

Besari, Sahari, (2008), Teknologi di Nusantara 40 Abad Hambatan Inovasi, Salemba Teknika, Jakarta.

Blackman, H.J. (1952) Six Existentialist Thinkers. London: Routledge dan Kegan Paul

Blalock, A. B. (1968). Methodology in Social Research. Mc Graw Hill Book Company. New York.

Blalock, H. M. (1972) Social Statistic. 2 nd ed. International Student Edition. Mc Graw Hill. Kogakhusa.

Bogdan, R. C. \&. Biklen, S. k. (2006) Qualitative research for education: An introduction to theories and methods.

Brackman, Arnold. (1963) Indonesian Communism, New York: Preager

Budiardjo, M. (1999) Dasar-Dasar Ilmu Politik. Jakarta: Gramedia Pustaka Utama 
Budiarjo, Miriam (1986) Dasar-Dasar Ilmu Politik. Jakarta: Gramedia Pustaka Utama

Budiati, A. C. (2009). Sosiologi Kontekstual: Untuk SMA dan MA Kelas X. Jakarta: Pusat Perbukuan, Departemen Pendidikan Nasional. ISBN 978979-068-219-1.

Budiono, A. (2018) 'Ilmu Hukum Sebagai Keilmuan Perspektif Paradigma Holistik.', 9(1), pp. 89-99.

Burbiel, J. (2009) Creativity in research and development environments: A practical review. Int J Bus Sci Appl Manag, 4. pp 35-51.

Buren, John Van. Martin Heidegger (1993) From the Earliest Essays to Being and Time and Beyond. New York: State University of New York Press, 1993.

Burger (1977) "Talcott Parsons, the Problem of Order in Society, and the Program of an Analytical Sociology." American Journal of Sociology. Vol. 83(2): pp. 320-339.

Burhanuddin Salam, (1988). Logika Formal (Filsafat Berpikir), Jakarta: Bina Aksara

Canard, M. (2011), "al-DِJazīra, Djazīrat Akūur or Iklīm Akūr", dalam Bearman, P.; Bianquis, Th.; Bosworth, C.E.; van Donzel, E.; Heinrichs, W.P., Encyclopaedia of Islam, Second Edition, Leiden: Brill Online, OCLC 624382576

Chaidar, Al; Sahrasad, Herdi (2013) Negara, Islam, Dan Nasionalisme Sebuah Perspektif. Jurnal Kawistara, 3.1.

Chairil, Robby. Soekarno (2010) dan perjuangan dalam mewujudkan kemerdekaan RI (1942-1945)

Chalmers A. F. (1983). Apa Itu yang Dinamakan Ilmu/Suatu Penelitian tentang Watak dan Status Ilmu serta Metodenya. Terjemahan Redaksi Hasta Mitra. Jakarta.

Chua, R. Y. J., dan Iyengar, S. S. (2008) Creativity as a matter of choice: Prior experience and task instruction as boundary conditions for the positive effect of choice on creativity. The Journal of Creative Behavior, 42(3), pp 164-180 
Cikgenc, (1995) Alparsian. Being and Existence in Sadra and Heidegger: A Comparative Ontology. Kuala Lumpur: ISTAC

Cokroaminoto (1985) Program Asas dan Progam Tandhim, Jakarta: Bulan Bintang

Cokroaminoto. (1995) Moeslim Nationale Onderwijs, Tafsir Program Asas dan Tandhim Syarekat Islam, Islam dan Sosialisme, Reglement Umum Bagi Umat Islam, Jakarta: Sekretariat Jendral Pimpinan Pusat/ Lajnah Tanfidziyah Syarikat Islam 1995.

Damsar (2015). Pengantar Sosiologi Politik Edisi Revisi (edisi ke-4). Jakarta: Prenadamedia Group. ISBN 978-602-9413-16-8.

Daud, A. (2016) 'Filsafat Manajemen Pemasaran: Kajian Historis dalam Persfektif Ontologi, Epistemologi dan Aksiologi', (June), pp. 1-23, doi: 10.13140/RG.2.1.4946.6486

Dunham, Sally (2005), "Ancient Near Eastern architecture", dalam Daniel Snell, A Companion to the Ancient Near East, Oxford: Blackwell, hlm. 266280, ISBN 0-631-23293-1

Eduardus Fromotius Lebe, (2015). http://eduarduslebe.blogspot.com/2015/11/ filsafat-pendidikan-idealisme.html

Elisanti dan Rostini, T. (2009). Sosiologi 1: untuk SMA /MA Kelas X. Jakarta: Pusat Perbukuan, Departemen Pendidikan Nasional. ISBN 978-979-068744-8.

Engels, Frederick, (2000) Feurbach dan Filsafat Jerman, Penerbit Teplok Press, Jakarta.

Erfan Rolis, Rolis, et al (2014). Pemikiran Dan Perjuangan Soekarno

Fahry, Majid (2001) Sejarah Filsafat Islam: Sebuah Peta Kronologis. Bandung: Mizan.

Faisal, Sanafiah, (2004), Desain Penelitian Sosial (format kualitatif dan Kuantitatif), Metodologi Penelitian Kualitatif, Penerbit PT RajaGrafindo Persada, Jakarta.

Fealy, Greg. (1998) Ijtihad Politik Ulama: Sejarah NU 1952-1967. Yogyakarta: LkiS Feisal, Jusuf A. Reorientasi Pendidikan Islam. Gema Insani 
Fend, H. (2002) "Educational institutions and society." International Encyclopedia of the Social and Behavioral Sciences. Oxford: Elsevier Science

Fensham, F. Charles (1962), "Widow, Orphan, and the Poor in Ancient near Eastern Legal and Wisdom Literature" (Journal of Near Eastern Studies Vol. 21, No. 2, pp. 129-139

Finkelstein, J.J. (1962), "Mesopotamia", Journal of Near Eastern Studies, 21 (2): 73-92, doi: 10.1086/371676, JSTOR 543884

Firdaus Wajdi (2012) 'Berfilsafat di Era Teknologi', Jurnal Studi Al-Qur'an Vol. 8, No. 1, Tahun

Firdaus, Dwi (2016) Hidayatul. Analisis Kebijakan Ekonomi Umar Bin Khattab Perspektif Bisnis Syariah. AT-Tahdzib: Jurnal Studi Islam, 1.2: pp 262278.

Formichi, Chiara (2010) Pan-Islam and Religious Nationalism: The Case of Kartosuwiryo and Negara Islam Indonesia. Indonesia, 90: pp 125-146

Foster, Benjamin R.; Polinger Foster, Karen (2009), Civilizations of ancient Iraq, Princeton: Princeton University Press, ISBN 978-0-691-13722-3

George J. Mouly (1991), Perkembangan Ilmu, dalam Ilmu dalam Perspektif: Sebuah Kumpulan Karangan Tentang Hakekat Ilmu, Jujun S. Suriasumantri. Jakarta: Gramedia

George, A.R., (2003). The Babylonian Gilgamesh Epic: Introduction, Critical Edition and Cuneiform Texts. Oxford University Press. hlm. 70-. ISBN 978-0-19-927841-1. Diakses tanggal 8 November 2012.

Ginting P., Situmorang S.H., (2008). Filsafat Ilmu Dan Metode Riset, USU Press Art Design, Publishing \& Printing, Medan

Gleick, James, (2006), Misteri Apel Newton, Kisah Pergulatan Seorang Isacc Newton, Penerbit Mizan, Bandung.

Gmirkin, Russell, (2006) "Berossus and Genesis, Manetho and Exodus.., Continuum p. 103. See also Blenkinsopp, Joseph, "Treasures old and new.." Eerdmans, 2004, pp. 93-95.

Golshani, Mehdi, (2003), Filsafat SainsMenurut Al Quran, Penerbit Mizan, Bandung. 
Goode, W. J. and P. K. Hatt. (1952) Method in Social Research. International Edition. Mc Graw Hill Kogakhusa. Ltd.

Gunawan I., (2012). Metode Penelitian Kuantitatif

Hadiwijono, Harun. Sari (2002) Sejarah Filsafat Barat 2. Yogyakarta: Kanisius.

Haeruddin, (2003), "Sumbangan Peradaban Islam terhadap Perkembangan Filsafat dan Ilmu Pengetahuan", Makalah Pengantar Filsafat Sain, Program Pasca Sarjana/S3, IPB.

Harahap N., Lubis S.D., (2011) Metodologi Penelitian Kuantitatif, PT. Gadja Mada Pustaka, Yoyakarta

Hardiman, F. Budi. Heidegger dan Mistik (2003) Keseharian: Suatu Pengantar Menuju Sein und Zeit. Jakarta: KPG Kepustakan Populer Gramedia, 2003.

Haryanto, Sindung (2015). Sosiologi Agama: Dari Klasik hingga Postmodern, Sleman: Ar-Ruzz Media. ISBN 978-602-313-028-3.

Hastjarjo T.D., (2011) Kausalitas Menurut Tradisi Donald Campbell, Buletin Psikologi, vol. 19(1):1-15

Hasyimsyah Nasution (1996), Filsafat Islam, Jakarta: Gaya Media Pratama, Herwansyah (2017) 'Pemikiran Filsafat Ibnu Sina', p. 6.

Hidayat A.R., (2018). Filsafat Berpikir Teknik-Teknik Berpikir Logis Kontra Kesesatan Berpikir, Duta Media Publishing, Pamekasan

Hidayat, F. (2016) 'Pengantar Teori-Teori Filsafat', p. 65.

Hifni, M. (2018) 'Ontologi, Epistemologi, dan Aksiologi dalam Keilmuan', STAIN Madura, (December).

Himyari Yusuf (2016). 'Urgensi Filsafat dalam Kehidupan Masyarkat Kontemporer: Tinjauan Filsafat Islam terhadap Fungsi Moral dan Agama', Jurnal Theologia - Volume 27 Nomor 1, Juni 2016

Huijbers, Theo (1987) Manusia Merenungkan Dirinya. Yogyakarta: Kanisius

Iffah Al Walidah (2017). 'Tabayyun di Era Generasi Milenial', Jurnal Living Hadis Vol. 2 Nomor 1, Oktober, 2017.

Imron Saefuddin (2012) 'Resume Buku Jurusan Biologi Fakultas Tarbiyah Institut Agama Islam Negeri (Iain) Syekh Nurdjati Cirebon', pp. 1-14. 
Iqbal, Muhammad (1981). The Recontruction of Religion Thought in Islam. New Delhi: Kitab Bhavan

Iqbal, Muhammad. Asrar'i Khudi (1976) Rahasia-Rahasia Pribadi, terj. Bahrum Rangkuti. Jakarta: Bulan Bintang.

Ja'far, S. (2018) 'Citra Manusia Dari Filsafat Psikologi Ke Filsafat Antropologi', Psympathic: Jurnal Ilmiah Psikologi, 3(2), pp. 196-204. doi: 10.15575/psy.v3i2.2188.

Ja'far, Suhermanto (2014) Orientasi Baru Filsafat Manusia menurut Islam. Surabaya: LP2M UINSA

Jalaluddin dan Abdullah, (1997) Filsafat Pendidikan. Jakarta: Gaya Media Pratama.

Jamaludin, A. N. (2016). Sosiologi Pembangunan. Bandung: CV. Pustaka Setia. ISBN 978-979-076-604-4.

Jejen Musfah (2011) 'Membumikan Pendidikan Holistik', Proceeding; Pendidikan Holistik Pendekatan Lintas Perspektif, pp. 1-15.

Jennie M. Xue (2017) ‘Kepemimpinan Holistik’, p. 2017.

Jujun S. Sumantri, (2005) Filsafat Ilmu: Sebuah Pengantar Populer. Jakarta: Sinar Harapan

Jujun S. Suriasumantri (2003) Filsafat Ilmu Sebuah Pengantar Populer. Jakarta: Pustaka Sinar Harapan

Jujun S. Suriasumantri, (1984) Ilmu dalam Perspektif. Jakarta: Gramedia

Karen Rhea Nemet-Nejat (1998), Daily Life in Ancient Mesopotamia

Karim, A., (2014) Sejarah Perkembangan Ilmu Pengetahuan, Jurnal Fikrah, Volume 2 Nomor 1

Kaufmann, Walter (1975). Existentialism from Dostoevsky to Sartre. New York: Meridian

KBBI (2008a) Kamus Besar Bahasa Indonesia, 2008. Available at: http://library1.nida.ac.th/termpaper6/sd/2554/19755.pdf.

KBBI (2008b) Kamus Besar Bahasa Indonesia.

Kees Bertens, (1995) Ringkasan Sejarah Filsafat, Edisi Revisi, cetakan ke 13, Yogyakarta: Kanisius. 
Khaidir Anwar, (1990) Fungsi Dan Penerapan Bahasa, Yogyakarta: Gadjah Mada University Press

Kirom, Sazalil, et al (2012) Buruh Dan Kekuasaan: Dinamika Perkembangan Gerakan Serikat Pekerja Di Indonesia (Masa Kolonial-Orde Lama). Jurnal Mahasiswa Teknologi Pendidikan, (2013). 1.1.

Kirom, Sazalil, et al. (2013) Buruh Dan Kekuasaan: Dinamika Perkembangan Gerakan Serikat Pekerja Di Indonesia (Masa Kolonial-Orde Lama). Jurnal Mahasiswa Teknologi Pendidikan, 1.1.

Knasas, John FX. (2003) Being and Some Twentieth-century Thomists. New York: Fordham University Press

Koento Wibisono, (2005) "Ilmu Pengetahuan, sebuah Sketsa umum mengenai Kelahiran dan Perkembangannya sebagai Pengantar untuk Memahami Filsafat Ilmu", dalam Koento Wibisono, Hubungan Filsafat, Ilmu Pengetahuan, dan Budaya, Hand Out, (Yogyakarta: Program Pascasarjana Filsafat UGM

Kohar, Abdul. (2012) Pendidikan Agama Berbasis Multikulturalisme (Studi Kritis). AT TA'DIB, VOL. 7.2.

Kurniawan, Syamsul, and Erwin Mahrus (2011) Jejak pemikiran tokoh pendidikan Islam: Ibnu Sina, Al-Ghazali, Ibn Khaldun, Muhammad Abduh, Muhammad Iqbal, Hassan al-Banna, Syed Muhammad Naquib al-Attas, KH Ahmad Dahlan, KH Hasyim Asy'ari, Hamka, Basiuni Imran, Hasan Langgulung, Azyumardi Azra. Ar-ruzz Media

Laksana, dkk. (2017). Buku Ajar Sosiologi Hukum (PDF). Tabanan: Pustaka Ekspresi. ISBN 978-602-5408-02-1.

Langiulli, Nino (1971). The Existentialist Tradition. USA: Yhe Anchor Books

Laning, Vina Dwi, (2008). Hidup Berbhinneka Tunggal Ika, Klaten: Cempaka Putih

Latifah, Tati. (2016) "Perenialisme" dalam Jurnal Tsarwah, Volume 1, No. 1, hlm 87.

Leahy, Louis, (2012) Esai Filsafat untuk Masa Kini; Telaah Masalah RohMateri Berdasarkan Data Empiris Baru, (Jakarta: Pustaka Utama Grafiti

Legge, J.D. (2000) Biografi Politik Sukarno, Jakarta: Sinar Harapan. 
Leksono-Supeli, Karlina (1994). Aku dalam Semesta: Suatu Kajian Filsafat atas Hubungan Subjek-Objek di dalam Kosmologi. Disertasi--Pascasarjana Universitas Indonesia Jakarta

Liana, D. (2020) 'Berpikir Kritis Melalui Pendekatan Saintifik', MITRA PGMI: Jurnal Kependidikan MI, 6(1), pp. 15-27, doi: 10.46963/mpgmi.v6i1.92.

Lubis, F. (2015) Pengantar Filsafat Umum, Ar Ruzz Media.

Luijpen, WA. (1960) Existential Phenomenology. New York: Duquesne Univ. Press

Nafiur M. Rofiq, (2018) Peranan Filsafat Ilmu Bagi Perkembangan Ilmu Pengetahuan, jurnal Ilmu keislaman,

Maharani, S. D., MS, Z., \& Nadiroh, N. (2019). Transformation of The Value of Religious Characters in Civic Education Learning in Elementary Schools. International Journal of Multicultural and Multireligious Understanding, 6(2), 295. https://doi.org/10.18415/ijmmu.v6i2.68 3

Mahawati, E. et al. (2021) Keselamatan Kerja dan Kesehatan Lingkungan Industri, Yayasan Kita Menuli. Edited by R. Watrianthos and Janner Simarmata. Medan.

Mahyudin Ritonga, (2013) Semantik Bahasa Arab: Kajian Makna alTad dalam Alquran. Padang: Hayfa Press

Malikah (2013) 'Kesadaran Diri Proses Pembentukan Karakter Islam Malikah Institut Agama Islam Negeri Sultan Amai Gorontalo', pp. 129-150.

Maman Kh, (2002). Menggabungkan Metode Penelitian Kuantitatif dengan Kualitatif', Makalah Pengantar Filsafat Sain, Program Pasca Sarjana/S3, IPB

Manan, N. A. (2020) 'Mesopotamia Dan Mesir Kuno: Awal Peradaban Dunia', Jurnal Adabiya, 22(1), p. 1, doi: 10.22373/adabiya.v22i1.7452.

Maragustam (2012) 'Paradigma Holistik-Integratif-Interkonektif Dalam Filsafat Manajemen Pendidikan Karakter', 11, pp. 67-79.

Marcel, Gabriel (1949) Being and Having, terj. Katharine Farrer. Glasglow: University Press

Marzuki, I. (2021) Pengantar Kimia Organik Fisis. 1st edn. Edited by A. Noor. Makassar: Tohar Media. 
Masri Singarimbun dan Sofian Effendi. (1982) Metode Penelitian Survai. Lembaga Penelitian, Pendidikan dan Penerangan Ekonomi dan Sosial (LP3ES). Jakarta.

Matthews, Roger (2003). The archaeology of Mesopotamia. Theories and approaches, Approaching the past, Milton Square: Routledge, ISBN 0415-25317-9

Mehra dan Burhan, (1996) Pengantar Logika Tradisional, Bandung: Binacipta

Mehra, P. S. (1968) Pengantar Logika Tradisional. Binacipta. Bandung.

Middya Boty (2017) 'Masyarakat Multikultural: Studi Interaksi Sosial Masyarakat Islam Melayu Dengan Non Melayu Pada Masyarakat Sukabangun Kel. Sukajadi Kec. Sukarami Palembang', Articel, 1(2), pp. $1-17$.

Miquel, A.; Brice, W.C.; Sourdel, D.; Aubin, J.; Holt, P.M.; Kelidar, A.; Blanc, H.; MacKenzie, D.N.; Pellat, Ch. (2011), "'Irāk", dalam Bearman, P.; Bianquis, Th.; Bosworth, C.E.; van Donzel, E.; Heinrichs, W.P., Encyclopaedia of Islam, Second Edition, Leiden: Brill Online, OCLC 624382576

Misiak, Henryk, dan Sexton, Virginia Staudt. (2005) Psikologi Fenomenologi, Eksistensial, dan Humanistik. Bandung: Refika Aditama

Moleong, Lexy J., (2002) Metodologi Penelitian Kualitatif (Bandung: Remaja Rosdakarya.

Muhadjir, Noeng. (2000) Metode Penelitian Kualitatif (Yogyakarta: Rake Sarasin).

Mukhtar Latif, (2014) Orientasi ke Arah Filsafat Ilmu. Jakarta: Kencana Prenadamedia Group

Mundiri, (2002) Logika, Jakarta: PT. Raja Grafindo Persada

Mundiri, (2006) Logika, Penerbit PT RajaGrafindo Persada, Jakarta.

Mundiri, (2008) Logika, Jakarta: PT.Raja Grafindo Persada

Muntansyir, Rizal \& Misnal Munir, (2006), Filsafat Ilmu, Pustaka Pelajar, Yogyakarta. 
Musianto, Lukas S, (2005) Jurnal Manajemen \& Kewirausahaan Vol. 4, No. 2, September 2002: 123 - 136, http://puslit.petra.ac.id/journals/manage ment/,

Muthahari, Murtadha (2002) Pengantar Pemikiran S \{adrâ, terj. Tim Penerjemah Mizan. Bandung: Mizan.

Muthahari, Murtadha. (2002) Pengantar Pemikiran Shadra, Filsafat Hikmah. Penerbit Mizan, Bandung.

Muzairi, (2009) Filsafat Umum, (Yogjakarta: Teras)

Nadiroh, \& Hasanah, U. (2018). Revolusi Industri dan Generasi Milenial. In Nadiroh, \& U. Hasanah, BUKU NON TEKS (p. 136). Jakarta: Direktorat Kerjasama Pendidikan Kependudukan, BKKBN.

Nasr, Sayyed Hosein., dan Leaman, Oliver (eds.) (2003) Ensiklopedi Tematis Filsafat Islam, terj. Tim Penerjemah Mizan. Bandung: Mizan

Nasr, Sayyed Hossein (1997) “Theology, Philosopy, and Sprituality”, dalam Seyyed Hossein Nasr (ed.), Islamic Spirituality: Manifestation. New York: Crossroad Publishing Company.

Nasution, Hasyimsyah, (1999) Filsafat Islam, (Jakarta: Gaya Media Pratama,

Natanson, Maurice (1973) Phenomenology and the Social Sciences. London: North-Western: University Press

Natasya Virginia Leuwol, P. W. et al. (2020) Pengembangan Sumber Daya Manusia Perguruan Tinggi. 1st edn. Edited by J. Simarmata. Medan. Available at: https://kitamenulis.id/2020/10/07/pengembangan-sumberdaya-manusia-perguruan-tinggi-sebuah-konsep-fakta-dan-gagasan/.

Noam Chomsky, (2000) Cakrawala Baru Kajian Bahasa Dan Pikiran, Terj.Freddy Kirana, Jakarta: PT Logs Wacana Ilmu

Noeng Muhadjir, (2003) Filsafat Islam Telaah Fungsional, Suplemen Filsafat Ilmu edisi II, (Yogyakarta: Rake Sarasin, 2003), 1.

Noor Ms Bakry, (1996) Logika Simbolik, Khusus Materi Logika Himpunan, Yogyakarta: Liberty

Nugraha, D. (2012) 'Sastra dan Sosiologi', (April 2011). doi: 10.13140/RG.2.2.28998.50249. 
Nur, Muhammad, (2015) "Kontribusi Filsafat Perenial dalam Meminimalisir Gerakan Radikal" dalam Jurnal Studi Agama dan Pemikiran Islam, Volume 9, No. 2, hlm 281.

Nurmansyah, G., Rodliyah, N., dan Hapsari, R. A. (2019). Pengantar Antropologi: Sebuah Ikhtisar Mengenal Antropologi. Bandar Lampung: CV. Anugrah Utama Raharja. ISBN 978-623-211-107-3.

Otto Trengginas Setiawan (2010) 'Universitas Indonesia Filsafat HolismeEkologis: Tanggapan Terhadap Paradigma Cartesian-Newtonian Depok'.

Partap Sing Mehra, (2002) Pengantar Logika Tradisional, Cet. ke-5, Bandung: Binacipta, 1996Poedjawijatna, Logika Filsafat Berpikir, Jakarta: PT Rineka Cipta

Partenie, Catalin, dan Rockmore, Tom (2003) (Eds.). Heidegger and Plato toward Dialogue. Evanston, Illinois: Northwestern University Press, 2003.

Peursen, C.A. Van. (1993) Susunan Ilmu Pengetahuan: Sebuah Pengantar Filsafat Ilmu. Diterjemahkan oleh J. Drost. PT Gramedia Pustaka Utama. Jakarta.

Poedjawijatna, LR (1980) Pembimbing ke Arah Alam Filsafat, (Jakarta: PT Pembangunan

Poedjiadi, A. and Al-Muchtar, S. (2014) 'Modul Pengertian Filsafat', Repository UT, pp. 1-29.

Poespoprodjo, (1987) Logika Scientifika Pengantar Dialektika Dan Ilmu, Bandung: Remadja Karya

Poespoprodjo, W, Gilarso, T. EK, (2006) Logika Ilmu Menalar, Dasar-Dasar Berpikir Tertib, Logis, Kritis, Analitis, Dialektis, Jakarta: Pustaka Grafika

Poespowardojo, Soerjanto. (1991) Filsafat Pancasila: Sebuah Pendekatan SosioBudaya. Lembaga Pengkajian Strategi dan Pembangunan dan PT Gramedia. Jakarta.

Preus, Anthony (2007) Historical Dictionary of Ancient Greek Philosophy. Lanham: Scarecow Press 
Priadi, A., Fatria, E., Nadiroh, Sarkawi, D., \& Oktaviani, A. (2018). Environmental citizenship behavior (the effect of environmental sensitivity, knowledge of ecology, personal investment in environmental issue, locus of control towards students' environmental citizenship behavior). E3S Web of Conferences, 74, 08002. https://doi.org/10.1051/e3sconf/201874 08002

Purba, P. B. et al. (2020) Dasar-dasar Manajemen Pendidikan. Edited by R. Wattrianthos. Meda: Yayasan Kita Menulis. Available at: https://kitamenulis.id/2020/12/14/dasar-dasar-manajamen-pendidikan/.

Raco J.R., (2010) Metode Penelltlan Kualltatlf Jenis, Karakteristik, Dan Keunggulannya, Grasindo, Penerbit PT Gramedia Widiasarana Indonesia, Jakarta

Rahardjo M., (2010). Antara Konsep, Proposisi, Teori, Variabel dan Hipotesis dalam Penelitian repository.uin-malang.ac.id/2410

Rahman, Fazlur (1995) Filsafat Shadra, terj. Munir A. Muin. Bandung: Pustaka.

Rapar, Jan Hendrik (1996) Pengantar Filsafat. Yogyakarta: Kanisius

Rasjidi, H.M., dan H. Harifuddin Cawidu, (1998) Islam untuk Disiplin Ilmu Filsafat, (Jakarta: Bulan Bintang

Ravertz, Jerome R. (2004) Filsafat Ilmu, Sejarah Ruang Lingkup dan Bahasan, Penerbit PustakaPelajar, Yogyakarta.

Rejeki, MC Ninik Sri (2010). "Perspektif Antropologi dan Teori Komunikasi: Penelusuran Teori-teori Komunikasi dari Disiplin Antropologi". Jurnal Ilmu Komunikasi. 7 (1): 41-60, doi:10.24002/jik.v7i1.195. ISSN 2548$\underline{8643}$.

Rendsburg, Gary. (2007) "The Biblical flood story in the light of the Gilgamesh flood account," in Gilgamesh and the world of Assyria, eds Azize, J \& Weeks, N. Peters, p. 117

Richard Bulliet; Pamela Kyle Crossley; Daniel Headrick; Steven Hirsch; Lyman Johnson; David Northup (2010), The Earth and Its Peoples: A Global History, Cengage Learning, 1 Jan 2010, ISBN 0538744383

Robert Dalling (2004), The Story of Us Humans, from Atoms to Today's Civilization

Roux, Georges, (1993) "Ancient Iraq" (Penguin) 
Rowston, Everet, (1988) A Muslim Philosopher on the soul and its fate: Alamiri's kitab Al-Amad Ala Al Abad, New Haven, Conn: American oriental Society, p-71

Rugani, Johari. (2020). Konsep Pemikiran Pendidikan Kebangsaan Haji Oemar Said Cokroaminoto Dalam Perspektif Pendidikan Islam, Penerbit. Tohar Media, Makassar

Salam, Burhanuddin. (2003). Pengantar Filsafat. Jakarta: Bumi Aksara

Sartre, Jean-Paul (1992) Being and Nothingness. New York: Simon dan Schuster

Satria; et al. (2020). "Landasan Antropologi Pendidikan dan Implementasinya Dalam Pembangunan Indonesia". Indonesian Journal of Social Science Education. 2 (1): - . ISSN 2655-6278

Scheffler, Thomas; (2003). "'Fertile crescent', 'Orient', Middle East': the changing mental maps of Southeast Asia," European Review of History 10/2: 253-272.

Schmid, Hans Bernhard (200) Plural Action Essays in Philosophy and Social Science. London New York: Springer Dordrecht Heidelberg

Schumacher, E.F. (1988) Keluar dari Kemelut: Sebuah Peta Pemikiran Baru. Jakarta: LP3ES

Sharif, M.M. (1963) A History of Mulsim Philosophy, Vol. 1. Lahore: Pakistan Philosophical Congress

Sheila C. Dow (2005), "Axioms and Babylonian thought: a reply", Journal of Post Keynesian Economics 27 (3), p. 385-391.

Shinta Nurulita, (2019) Pengaruh Perkembangan Ilmu Pengetahuan dan Teknologi Terhadap Masyarakat dan Lingkungan.

Sirajuddin, (2004) Filsafat Islam, Jakarta: Grafindo Persada, 2004

Sisdiknas No. 20 Thn. 2003 (2003) 'UU No. 20 Tahun 2003 tentang Sistem Pendidikan Nasional', Acta Pædiatrica, 71, pp. 6-6, doi: 10.1111/j.16512227.1982.tb08455.x.

Soekadijo, R.G, (2001) Logika Dasar Tradisional, Simbolik dan Induktif. Jakarta: Penerbit Gramedia Pustaka Utama 
Solomon, Robert C., (1973). From Rationalism to Existentialism. USA: Harper dan Row,

Sou'yb Joesoef, (2001) Logika Kaidah Berfikir Secara Tepat, Jakarta: PT AlHusna Zikra

Sudarmanto, E. et al. (2020) Konsep Dasar Pengabdian Kepada Masyarakat; Pembangunan dan Pemberdayaan. Edited by A. Karim and J. Simarmata.

Medan: Yayasan Kita Menulis. Available at: https://kitamenulis.id/2020/12/22/konsep-dasar-pengabdian-kepadamasyarakat-pembangunan-dan-pemberdayaan/.

Sulhatul Habibah, (2017) Implikasi Filsafat Ilmu Terhadap Perkembangan Ilmu Pengetahuan dan Teknologi.

Sumaryono, (1999) Dasar-Dasar Logika, Yogyakarta: Kanisius

Suparlan Suhartono (2005), Sejarah Pemikiran Filsafat Modern. Yogyakarta: Ar Ruzz Media

Suprawati MM. N.E, (2009) Pendekatan Kuantitatif Dan Kualitatif Filsafat Ilmu Untuk Penelitian Psikologi. J. Orientasi Baru, Vol. 18(2): 177-194

Surajiyo (2008) Filsafat Ilmu dan Perkembangannya di Indonesia. Jakarta: Bumi Aksara

Surajiyo, (2008), Filsafat Ilmu \& Perkembangannya di Indonesia, Bumi Aksara, Jakarta.

Surajiyo, (2013) Filsafat Ilmu dan Perkembangannya di Indonesia. Jakarta: Bumi Aksara

Surajiyo, Asnanto, dkk, (2006) Dasar-dasar logika, Jakarta: Bumi aksara

Surajiyo, dkk. (2006). Dasar-dasar Logika. Jakarta: Bumi Aksara.

Susanto, (2013) Filsafat Ilmu Suatu Kajian dalam Dimensi Ontologis, Epistemologis dan Aksiologis. Jakarta: Bumi Aksara

Suseno, Franz Magnis (1999), Berfilsafat dari Konteks, (Jakarta: Garmedia Pustaka Utama

Sutisna, I. et al. (2017) 'Relasional Ilmu Filsafat Dengan Pendidikan.

Sutiyono, A (2003) 'Membangun Motivasi Diri berbasis pada Nilai Kecerdasan Berbasis Neuroscience: IQ, EQ dan SQ'. 
Syafrizal et al. (2021) Pengantar Ilmu Sosial, Yayasan Kita Menulis. Edited by R. Watrianthos. Medan: Yayasan Kita Menulis

Syaifuddin Sabda (2020) 'Paradigma Pendidikan Holistik', Pedagogi, 1(1), pp. 29-36.

Taufik, Abdullah. (1977) Mengapa Biografi, Yogyakarta: Prisma

Thamrin, Winny Puspasari, Kusumatuti, Astri Nur, Setiawan Budi, (2013). Filsafat Ilmu, Jakarta

Thompson, William R. (2004) "Complexity, Diminishing Marginal Returns, and Serial Mesopotamian Fragmentation" (Jilid 3, Journal of World Systems Research)

Townsend, H. G. and Smuts, J. C. (1928) 'Holism and Evolution', The Philosophical Review, 37(1), p. 85, doi: 10.2307/2179530.

Uhar Suharsaputra, (2004) Pengatar Filsafat Ilmu Jilid I, Uiversitas Kuningan, 2004

Vahid, Syed Abdul (1973). Thought and Reflections of Iqbal. Lahore: SH. Muhammad Ashraf

Van Melsen (2010) Ilmu Pengetahuan dan Tanggung Jawab Kita.(terj. K. Bertens, Jakarta: Gramedia

Vardiansyah, Dani. (2008) Filsafat Ilmu Komunikasi: Suatu Pengantar, Indeks, Jakarta 2008. Halaman 20.

Wahidin, Dadan. (2009) Filsafat dan Ilmu. Jakarta

Warren, James, (2004) Facing Death: Epicurus and his Critics. Oxford: Clarendon Press

Wilkinson, Tony J. (2000), "Regional approaches to Mesopotamian archaeology: the contribution of archaeological surveys", Journal of Archaeological Research, 8 (3): 219-267, doi: 10.1023/A:1009487620969, ISSN 1573-7756

Winter, Irene J. (1985). "After the Battle is Over: The 'Stele of the Vultures' and the Beginning of Historical Narrative in the Art of the Ancient Near East". In Kessler, Herbert L.; Simpson, Marianna Shreve. Pictorial Narrative in Antiquity and the Middle Ages. Center for Advanced Study in the Visual Arts, Symposium Series IV. 16. Washington DC: National Gallery of Art. pp. 11-32. ISSN 0091-7338. 
Wiyono, M. (2016) 'Pemikiran Filsafat Al-Farabi', Substantia, 18(1), pp. 6780.

Yogiswari, K. S. (2018) 'Pendidikan Holistik Jiddu Krishnamurti', Guna Widya: Jurnal Pendidikan Hindu, 5 (1), pp. 33-42, doi: 10.25078/gw.v5i1.610.

Yuliana, N., R, M. D. and Fahri, M. (2020) 'Model Pendidikan Holistik Berbasis Karakter Di Sekolah Karakter Indonesia Heritage Foundation', EduHumaniora | Jurnal Pendidikan Dasar Kampus Cibiru, 12(1), pp. 1524, doi: 10.17509/eh.v12i1.15872

Yusuf. Al-Ibadah, Al-Qardhawi, (1995) al-Islam. Maktabat Wahbah, 1995

Zainun Kamal, (2006) Ibnu Taimiyah Versus para Filosof, Polemik Logika, Jakarta: PT RajaGrafindo Persada

Zen, M.T (Ed.). (1984) Sains, Teknologi, dan Hari Depan Manusia. Diterbitkan untuk Yayasan Obor Indonesia. Penerbit PT Gramedia. Jakarta.

Ziai, Hossein. Suhrowardi, (1998) dan Filsafat Illuminasi: Pencerahan Ilmu Pengetahuan, terj. Afif Muhammad. Bandung: Zaman,

Zubair, A. Charris, (2002), Dimensi Etik dan Asketik Ilmu Pengetahuan Manusia: Kajian Filsafat Ilmu, Lembaga Studi Filsafat Islam (LESFI), Yogyakarta. 


\section{Biodata Penulis}

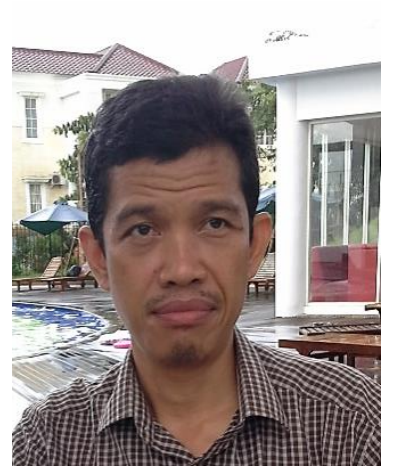

Dr. Ismail Marzuki, M.Si, lahir di Kabere, 03 Juli 1973. Pendidikan formal yang telah diikuti SD Negeri 19 Kabere Tahun 1980-1986, SMP Negeri Kabere Tahun 1986-1989, dan SMA Negeri 1 Enrekang 1989-1992. Gelar sarjana Sains (kimia) disandang tahun 1999, di Jurusan Kimia F.MIPA UNHAS, dan gelar Magister Sains (M.Si) Tahun 2003. Menyelesaikan program Doktor tahun 2016, Program Pascasarjana UNHAS.

Karir sebagai akademisi dimulai tahun 2000 hingga sekarang. Status PNS (Dosen) diperoleh pada Tahun 2005, pada unit kerja Kopertis (L2dikti) wil. IX Sulawesi. Jabatan struktural yang pernah di sandang, yakni: Direktur Akademi Analis Kimia Yapika Makassar, (Tahun 2002-2008), Ketua I Bidang Akademik Sekolah Tinggi Ilmu Kesehatan (STIKES) Yapika Makassar (Tahun 2008-2012). Ketua Stikes Bina Mandiri Gorontalo (Tahun 2014-2015), Dimutasi ke Universitas Fajar (UNIFA), Tahun 2015, pada Prodi home base Teknik Kimia. Tugas tambahan yang diamanahkan oleh UNIFA adalah Pimred Jurnal Techno Entrepreneur Acta (2016-sekarang), Ketua Unit Pusat Karir UNIFA (Tahun 2016-2018) dan Ketua Lembaga Penjaminan Mutu Internal UNIFA, (2019-2020), serta Dekan Fak. Pascasarjana Univ. Fajar, (2020-sekarang). Sejak pandemic coviv-19 dan masa pemulihan dengan kebiasaan hidup baru bergabungan dalam komunitas Yayasan Kita Menulis, yang hingga saat ini telah menulis 20 book chapter dan 3 tahun terakhir sebagai dosen pengajar filsafat pada Program S2 Universitas Fajar. 


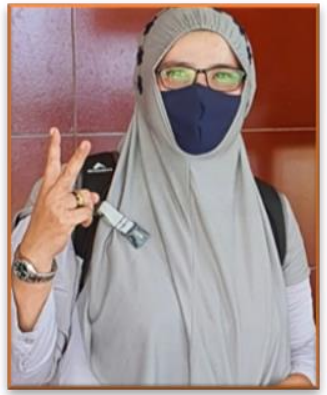

Johra, S.Pd, lahir di Maros, 31 Januari 1976. Pendidikan formal yang telah diikuti SD Negeri 10 Bantimurung - Maros Tahun 1983-1989, SMP Negeri Bantimurung - Maros Tahun 1989-1992, dan SMA Negeri 1 Merauke - Papua 1992-1995. Gelar Sarjana Pendidikan tahun 2002, di Jurusan Pendidikan Teknik Bangunan Fakultas Teknik UNM, dan sedang menempuh study pada Progam Studi MRIL

Fakultas Pascasarjana UNIFA Makassar Tahun 2020 hingga sekarang. Karir sebagai guru dimulai tahun 2002 hingga sekarang. Status PNS (Guru) diperoleh pada Tahun 2005, pada unit kerja SMK Negeri 2 Manokwari Papua Barat. Jabatan yang pernah di sandang, yakni: Wakil Kepala Sekolah bidang Humas dan Industry SMK Negeri 2 Manokwari, (Tahun 2010-sekarang), Ketua Program Studi Teknik Bangunan (Tahun 2007-2010), Ketua Program Studi Geologi Pertambangan (Tahun 2020sekarang).

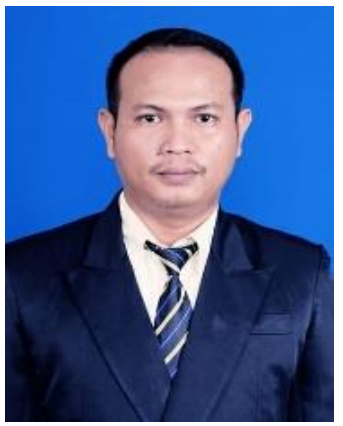

Arwansyah, ST., lahir di Ujung Pandang pada tanggal 28 Oktober 1982. Telah menempuh Pendidikan formal, yaitu pada SD Negeri No. 3 Barabaya Kota Ujung Pandang pada Tahun 1988 - 1994, SMP Negeri 10 Makkasar pada Tahun 1994 - 1997, dan SMK Negeri 2 Ujung Pandang pada Tahun 1997 - 2000. Gelar Sarjana Teknik (S.T.) diraih di Universitas "45" Makassar Tahun 2009 dengan Jurusan Teknik Sipil. Saat ini sedang menempuh Pendidikan S2 dengan Program Studi Magister Rekayasa Infrastruktur dan Lingkungan (MRIL) Fakultas Pascasarjana, Universitas Fajar Makassar sejak Tahun 2020 hingga sekarang. 


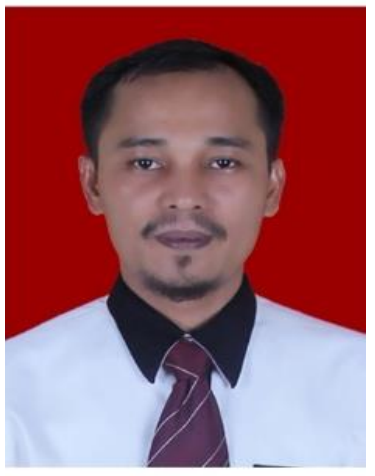

Asrudin, ST, lahir di Puao, 08 Juni 1976, sebuah Desa yang terletak di Kabupaten Konawe Selatan Provinsi Sulawesi Tenggara. Pendidikan formal yang telah diikuti SDN Puao 1986-1989 kemudian menamatkan Pendidikan Sekolah Dasar di SDN 2 Lamooso Tahun 1990, SMP Negeri Motaha Tahun 1990-1993, dan STM Negeri Kendari 1993-1996. Gelar sarjana Teknik disandang tahun 2004, di Jurusan Teknik Sipil Universitas " 45 ". Pengalaman organisasi dimulai sejak dalam dunia kemahasiswa, yaitu sebagai Ketua Himpunan Mahasiswa Sipil Univ. "45" tahun 1999-2000, Ketua Badan Pembentukan Majelis Permusyawaratan Mahasiswa Univ. "45" tahun 2002, Ketua Bidang di HMI Cabang Makassar tahun 2001-2002

Karier pekerjaan dimulai pada tahun 2006 sebagai tenaga honorer Pemerintah Provinsi Sulawesi Barat dan diperbantukan sebagai tenaga teknis pada Satker Pengembangan Penyehatan Lingkungan Permukiman Sulawesi Barat sampai dengan tahun 2013. Pada tahun 2015 terangkat menjadi PNS/ASN dan di tempatkan di Dinas PUPR Provinsi Sulawesi Barat dan mengabdi sampai tahun 2018. Tahun 2019 sampai sekarang dipindah tugaskan pada Biro Pengadaan Barang dan Jasa dengan tugas pokok sebagai Pokja Pemilihan Pengadaan Barang dan Jasa Pemerintah Provinsi Sulawesi Barat.

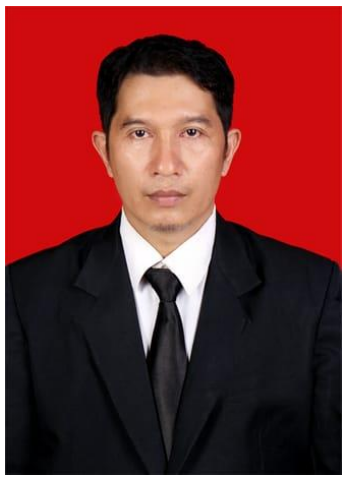

Ir.Zaenal, ST Lahir di Bulukumba 19 Mei 1976. Pendidikan Formal yang talah di ikuti SD Negeri 82 Batupangka Kabupaten Bulukumba Tahun 1983-1989, SMP Negeri Palampang Kabupaten Bulukumba Tahun 1989-1992, STM Pembanguna Negeri Makassar Tahun 1992-1996, Gelar Sarjana (Teknik Sipil) di Universitas Muhammadiyah Makassar Tahun 2010, Profesi Insinyur di Universitas Hasanuddin Gowa Tahun 2020.dan Sedang menempih study pada program Study MRIL Fakultas Pascasarjana UNIFA Makassar Tahun 2020 hingga sekarang. Karir sebagai Konsultan PengawasPerencana dimulai Tahun 1997 hingga saat ini. 


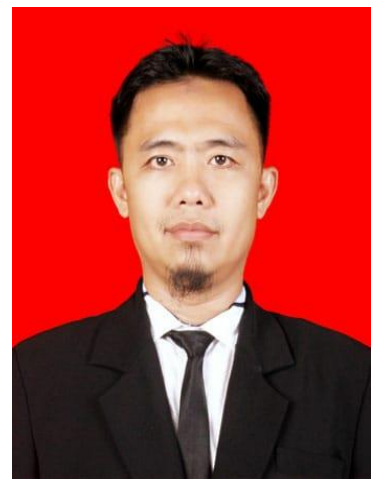

Muhammad Riadi Harimuswarah, ST. lahir pada 12 Maret 1978, Domisili saat ini di Jl. Traktor I No. 15 Komp. PU Mallengkeri Makassar. Pendidikan Starata Satu Teknik Sipil Universitas Hasanuddin. Pekerjaan saat ini pada Dinas Pekerjaan Umum dan Penataan Ruang Kab. Bulukumba, surel: mrharimuswarah2 @ gmail.com. Saat ini sedang melanjutkan pendidikan pada program Pascasarjana Universitas Fajar pada Program Studi Magister Rekayasa Infrastruktur dan Lingkungan *MRIL).

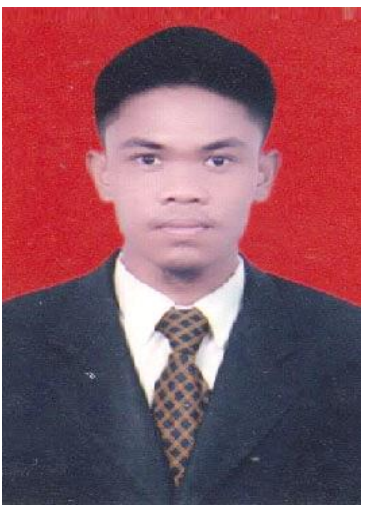

Muhammad Syahrir, S.S., Lahir di Pinrang, 27 Oktober 1990. Pendidikan formal yang telah diikuti SD Negeri 27 Pinrang tahun 1997-2003, SMP Negeri 2 Pinrang Tahun 2003-2005, dan SMA Negeri 2 Pinrang Tahun 2005-2008. Gelar Sarjana Sastra disandang tahun 2014 di Jurusan Arkeologi FIB UNHAS. Saat ini sedang menjalani masa studi magister di Pascasarjana Unifa. 


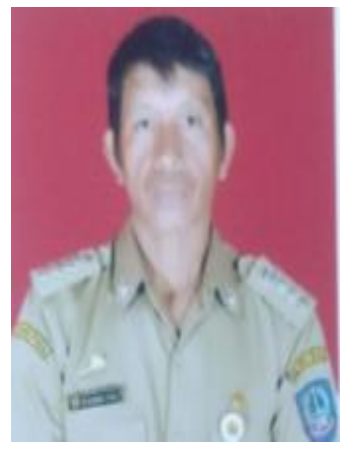

Muhammad Ramli, Tempat dan tanggal Lahir: Cenrana, 02 April 1972.Kecamatan Kahu Kab Bone Prov, Sulawesi Selatan. Pendidikan SD No. 279 Cenrana 1985. SMP Neg. 1 Palattae Kec.Kahu 1988. STM Neg. 1 Ujung Pandang 1991. Sarjana Strata Satu pada Institut Sains Teknologi Pembangunan Indonesia (IST-PI) 2015. Saat ini sedang bertugas di Kabupaten Bone pada bagian Irigasi

Pendidikan Magister Pascasarjana Rekayasa Infrastruktur dan Lingkungan 2020-sekarang pada Universitas Fajar Makassar. Riwayat Pekerjaan PT Yodya Karya Ujung Pandang 1991-1992 PT. Hutama Karya Kendari 1993-1997. Dinas PU Pengairan sampai sekarang tugas pengatur pintu air (PPA).

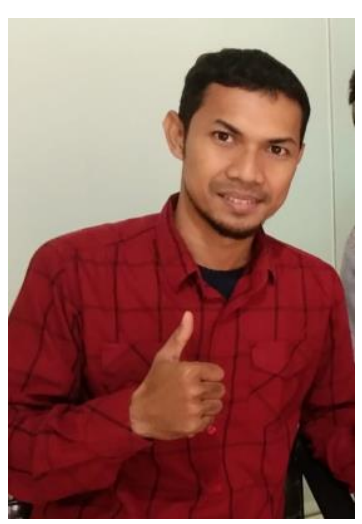

Akbar Hadi, ST, lahir di Rappang, 04 September 1987. Pendidikan formal yang telah diikuti SD Inpres Perumnas Antang III Makassar Tahun 1996-1999, MTs AT-Taqwa Beru Maumere-NTT Tahun 1999-2002, dan SMK Negeri 1 Maumere-NTT 2002-2005. Gelar Sarjana Teknik (Sipil) disandang tahun 2011, di Jurusan Sipil Fakultas Teknik UMI.

Karir sebagai jurnalis Koran Makassar (Tahun 2011-2012), Jurnalis Harian Rakyat Sulsel (Tahun 2012-2014), Jurnalis Koran Tempo Makassar (Tahun 2014-2017), Redaktur Makassar Terkini (Tahun 2017) Pendamping Desa Teknik Infrastruktur (PDTI) di Kabupaten Maros (Tahun 2017-2019), Fasilitator Masyarakat Program Pengembangan Infrastruktur Sosial Ekonomi Wilayah (PISEW) Kementerian PUPR di Kabupaten Luwu (Tahun 2019-2020). 




\section{SINOPSIS}

Menulis adalah melukiskan suatu yang ada dalam pikiran atau membuat memori menjadi kenyataan dan sebagian mengatakan mengaksarakan pikiran dan logika dalam media. Makna sederhana tentang menulis adalah menyampaikan ide dalam suatu platform baik melalui kertas atau media digital. Tulisan adalah ibarat symbol masa lampau tentang peradaban manusia, mengejawantahkan persembahan manusia tentang pemahaman suatu zaman atau sebuah katalis dari peradaban manusia. Berangkat pada makna di atas, maka setiap menulis adalah karya yang harus disusun atas landasan perencanaan dan penyusunan yang matang, agar memberi pencerahan yang baik pada suatu topik ulasan. Penyusunan tersebut tentunya memiliki filosofi tersendiri yang berbeda dengan yang lain. Tulisan berjudul "Filsafat IImu di Era Milenial" sudah sangat banyak dan tersebar luas di banyak kalangan, meskipun demikian, buku ini tetap mempunyai nilai filosofis dengan makna berbeda dengan karya sejenis sebagai torehan pemikiran yang berbeda minimal pada aspek ruang dan waktu. Buku ini terdiri atas 9 Bab, yakni:

Bab I Filsafat dalam Ontologi, Epistemologi dan Aksiologi;

Bab II Filsafat Konvensional dan Filsafat Modern di Abad Kemajuan IPTek;

Bab III Filsafat Zaman Yunani;

Bab IV Konsep Filsafat Pendidikan Kebangsaan Cokroaminoto;

Bab V Manusia dan Perkembangan Ilmu Pengetahuan;

Bab VI Filsafat dan Holisme;

Bab VII Idealisme Filsafat terhadap Metode Kualitatif dan Kuantitatif;

Bab VIII Irisan Filsafat terhadap Logika dan Silogisme;

Bab IX Filsafat di Era Generasi Milenial.

Pilihan materi dalam setiap Bab yang disajikan merupakan topik-topik yang dipandang sebagai bagian yang berperan dalam merunut kembali perkembangan ilmu pengetahuan dulu dan kini.

Buku ini berusaha untuk menyambungkan kembali alur pengetahuan yang dianggap renggang akibat munculnya era globalisasi yang dibarengi dengan model kehidupan yang rumit dimasa lampau dan kehidupan era milenial kini.

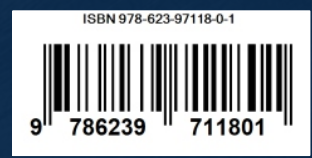

